Fabiana Rodrigues Dias

\title{
A retórica racialista da branquitude nas disputas pela definição da ideia de brasileiro (1820-1847)
}

Tese de Doutorado

Tese apresentada como requisito parcial para obtenção do grau de Doutora pelo Programa de Pós-graduação em História Social da Cultura do Departamento de História da PUC-Rio.

Orientador: Prof. Marco Antonio Villela Pamplona 
Fabiana Rodrigues Dias

\section{A retórica racialista da branquitude nas disputas pela definição da ideia de brasileiro (1820-1847)}

\section{Tese de Doutorado}

Tese apresentada como requisito parcial para obtenção do grau de Doutora pelo Programa de Pós-graduação em História Social da Cultura do Departamento de História da PUC-Rio. Aprovada pela Comissão Examinadora abaixo:

Prof. Marco Antônio Villela Pamplona

Orientador

Programa de Pós-graduação em História Social da Cultura

PUC-Rio

Profa. Juçara Mello Programa de Pós-graduação em História Social da Cultura PUC-Rio

Prof. Eduardo Wright Cardoso Programa de Pós-graduação em História Social da Cultura

PUC-Rio

Profa. Lorelai Brilhante Kury Programa de Pós-graduação em História das Ciências e da Saúde - COC - Fiocruz

Prof. Daniel Pinha Silva Programa de Pós-graduação em História UERJ

Rio de Janeiro, 17 de dezembro de 2020. 
Todos os direitos reservados. É proibida a reprodução total ou parcial do trabalho sem a autorização da universidade, da autora e do orientador.

Fabiana Rodrigues Dias

Possui Bacharelado e Licenciatura em História pela UERJ, 2007. Mestrado em História Política pela UERJ, 2009. Atua como Professora e Pesquisadora.

Ficha Catalográfica

Dias, Fabiana Rodrigues

A retórica racialista da branquitude nas disputas pela definição da ideia de brasileiro (1820-1847) / Fabiana Rodrigues Dias; orientador: Marco Antonio Villela Pamplona. - 2020.

198 f. ; $30 \mathrm{~cm}$

Tese (doutorado)-Pontifícia Universidade Católica do Rio de Janeiro, Departamento de História, 2020.

Inclui bibliografia

1. História - Teses. 2. História Social da Cultura - Teses. 3. Nação. 4. Racismos. 5. Retórica civilizatória. 6. Branquitude. 7. Império do Brasil. I. Pamplona, Marco Antonio Villela. II. Pontifícia Universidade Católica do Rio de Janeiro. Departamento de História. III. Título. 
Para meu filho, João Cândido Dias Fiuza, por ser minha existência continuada. 


\section{Agradecimentos}

À CAPES, por conceder a bolsa de pesquisa que financiou este trabalho entre 2016 e 2018. À PUC-Rio, pela concessão da Bolsa VRAC e por todo o suporte administrativo. Agradeço igualmente à FAPERJ, que muito me honrou ao me contemplar com a Bolsa FAPERJ Nota 10 nos dois últimos anos de pesquisa. $\mathrm{O}$ resultado deste trabalho não seria o mesmo, não fosse esse incentivo.

Ao Prof. Dr. Marco A. Pamplona, orientador deste trabalho, por ter me encorajado a reinventar o projeto de tese. Agradeço-lhe, ainda, pelo carinho, apoio e incentivo dispensados a mim e à minha pesquisa durante os últimos quatro anos. Espero ter feito jus ao posto de última orientanda de doutorado de sua carreira.

Ao Programa de Pós-Graduação em História Social da Cultura e ao Departamento de História, representados na competência e empatia de seus funcionários. Agradeço aqui a Claudio Santiago e Edna, com quem desenvolvi maior contato ao longo desses anos. Ao Prof ${ }^{\circ}$ Dr. Antonio Galeano, Coordenador da Pós à época em que fui contemplada pela FAPERJ Nota 10, pela solidária orientação com a elaboração de toda a documentação; ao Professor Dr. Marcelo Jasmin, pelas aulas incríveis; à Profa. Dra. Regiane Augusto de Mattos, pelas sugestões valiosas e pela leitura empática de meus textos na ocasião dos Seminários de Tese; à Profa. Dra. Maria Elisa Noronha de Sá, pelas aulas provocadoras e pelas sugestões e críticas realizadas no exame de qualificação; e ao querido Prof. Dr. Ilmar Rohloff de Mattos que, com toda a modéstia, me ofereceu sugestões e me incentivou, quando este trabalho era ainda preliminarmente desenvolvido.

Agradeço, enfaticamente, aos Professores que aceitaram participar da banca avaliativa desta tese: Prof. Dr. Eduardo Wright Cardoso (PUC-Rio), Profa. Dra. Juçara Mello (PUC-Rio), Profa. Dr. Daniel Pinha (UERJ) e Profa. Dra. Lorelai Kury (COC- FIOCRUZ).

Aos meus colegas de turma, sobretudo à Ana Carolina Guedes, Andrea Forti, Gleyce Kelly Heitor, Juliene Tardelli, Rodrigo Fampa, Vitor e Waleska Maia. Agradeço-lhes pela amizade, pelas trocas acadêmicas, e pelas sugestões ao meu trabalho.

Aos meus amigos da vida, por terem contribuído mais do que podem supor para esta tese. Gustavo Amorim e Andrea Pagano, Bruno Pettinelli e Flavia Nunes, Daniel Paes, Roberta Valente e Rodrigo Leonardo, Rodrigo Fleck, Rodrigo 
Mendes, Gabriela Serpa e Altino Pereira, obrigada por serem alegria e escape. Agradeço, em especial, à Julia Machado, por compartilhar incentivo e seus métodos dinamarqueses de concentração; à Tatiane Cova, pela amizade que vem de longe e por dividir o interesse pelo tema; à Thaiza Senna, por ter sido, mesmo que involuntariamente, fundamental para que este doutorado fosse uma possibilidade.

Por fim, agradeço à minha família, em especial aos meus pais. Agradeço, ainda, àqueles que com amor e leveza dividem o cotidiano comigo: Marcos Fiuza, obrigada pelo apoio, pelo astral e por ser a primeira escuta dos meus textos; e João Cândido, que com seu sorriso e com seus reiterados abraços arrefeceu os momentos mais tensos da escrita, obrigada meu amor. 


\section{Resumo}

Dias, Fabiana Rodrigues; Pamplona, Marco Antonio Villela. A retórica racialista da branquitude nas disputas pela definição da ideia de brasileiro (1820-1847). Rio de Janeiro, 2020. 198 p. Tese de Doutorado Departamento de História, Pontifícia Universidade Católica do Rio de Janeiro.

Com esta tese, busco problematizar a dimensão racialista de textos pioneiros da discussão da ideia de pátria e de nação, gestados na esteira dos debates independentistas emanados do Rio de Janeiro, durante a primeira metade do século XIX. Considerando a hipótese de que esta dimensão constituiu aspecto determinante para a orientação das ações e do imaginário da dita boa sociedade da época, analiso os escritos de José Bonifácio, Gonçalves de Magalhães, TorresHomem, Bernardo Pereira de Vasconcelos, Januário da Cunha Barbosa e K.F.P. von Martius. A partir desses textos, discuto os usos e apropriações feitas por esses autores da ampla retórica de hierarquização dos povos, associados às suas expectativas de definição do Brasil e do brasileiro. Assim, procuro demonstrar os modos pelos quais esses autores mobilizaram, cada qual a sua maneira, o vasto repertório da retórica da branquitude autorreferenciada e identificada à civilização. Mais ainda, demonstro como puderam ser atualizadas, simultaneamente, noções seculares de inferiorização moral e fenotípica daqueles "outros" identificados como negros e índios, ao longo da construção desse Estado e da definição de sua subjetividade nacional.

\section{PALAVRAS-CHAVE}

RACISMOS - RETÓRICA CIVILIZATÓRIA - BRANQUITUDE - IMPÉRIO DO BRASIL - NAÇÃO 


\section{Abstract}

Dias, Fabiana Rodrigues; Pamplona, Marco Antonio Villela (advisor). The racialist rhetoric of whiteness in the disputes over the definition of the idea of being Brazilian (1820-1847). Rio de Janeiro, 2020. 198 p. Tese de Doutorado - Departamento de História, Pontifícia Universidade Católica do Rio de Janeiro.

I seek, in this dissertation, to problematize the racialist dimension of pioneering texts referred to the discussion of the idea of patria (homeland) and nation, in the wake of the independent debates that emanated from Rio de Janeiro during the first half of the 19th century. By considering the hypothesis that such a dimension constituted a decisive aspect in the guiding of the attitudes and imaginings of those who pertained to the better sort of society at the time, I analyze the writings of José Bonifácio, Gonçalves de Magalhães, Torres-Homem, Bernardo Pereira de Vasconcelos, Januário da Cunha Barbosa and K.F.P. von Martius. I discuss the uses and appropriations these authors made of the broad rhetoric of hierarchizing peoples, in accordance with their own expectations concerning the definition of Brazil and of Brazilians. Therefore, I try to demonstrate the ways in which these authors have mobilized, each one in its own way, the vast repertoire of the rhetoric of a self-referent whiteness identified with civilization. In addition, I demonstrate how centuries-old notions of moral and phenotypic inferiority of those "others", namely the Negroes and the Indians, along the State-building process and its definition of what nationhood should mean.

\section{KEY WORDS}

RACISMS - RHETORICS OF CIVILIZATION - WHITENESS - BRAZILIAN EMPIRE - NATION 


\section{Sumário}

1. Introdução: A culpa deve ser do sol

2. Diagnósticos e horizontes de um Estado em definição 20

2.1 Das diferenças e dos discursos hierarquizantes 21

2.2 Dos povos e das pátrias do Brasil 36

2.3Da retórica civilizatória e da noção de aperfeiçoamento 49

3. Quem constitui a paleta local? 70

3.1 Entre o exótico e o autêntico 71

3.2 Da urgência da originalidade 92

3.3 O indianismo e a inferioridade reiterada 106

3.4 O negro e o não-pertencimento à pátria do Brasil 115

4. Um Estado, uma História, um povo: aparente unidade 131

4.1 O Regresso e a positivação do escravismo 132

4.2 Nuances racialistas do discurso antiescravista 148

4.3 O enredo nacional e a atualização da retórica racialista 159

5. Considerações finais: Ausência do mesmo ou presença alheia 179

Referências Bibliográficas 
Sol, a culpa deve ser do sol Que bate na moleira, o sol Que estoura as veias, o suor Que embaça os olhos e a razão

Chico Buarque 
1. Introdução

A culpa deve ser do sol 
Os versos de Caravanas que nos servem de epígrafe, não nos permitem hesitar a respeito da atualidade da questão que norteia esta tese. As referências presentes nas demais estrofes a negros torsos nus vindos dos subúrbios imunes à maresia, como corpos que incomodam a gente ordeira e virtuosa que habita à beiramar, evocam uma série de significados. Não apenas os corpos, mas os modos desses estranhos encarnam aquilo que as classes médias e altas, não por acaso brancas, enxergam como alheios à sua existência. Um olhar enviesado, que imagina facões e adagas escondidos nas sungas e calções disformes. Uma espécie de atualização da ideia de barbárie compartilhada pelos colonizadores europeus. Permanências profundamente arraigadas no olhar, no imaginário e nos discursos que se constroem a partir das imbricadas interações entre o ideal de branquitude, a condição econômica e a adesão aos marcadores civilizatórios da polidez e da contenção. Noções, ainda hoje, capazes de fazer associar os comportamentos das gentes à incidência maior ou menor do sol sobre o chão, sobre os corpos.

Caravanas recupera, destarte, uma das frentes de uma complexa e ampla tradição discursiva de hierarquização dos povos. Uma construção retórica repleta de camadas, de sobreposições, de nuances e de reapropriações. Arcabouço do qual procuramos dar conta já na primeira parte desta tese. Mas voltando a Chico Buarque, o que Caravanas recupera dessa retórica é a sua face enunciada pela razão ilustrada, a que costurou, sobretudo com Buffon e Montesquieu, a noção de que a condição fisiológica e o caráter dos povos seriam determinados pelas condições do ambiente no qual viviam. Na esteira desses pensadores francófonos, o diagnóstico da inferioridade física e moral das humanidades não europeias passaria também a se justificar pelas condições adversas que a paisagem e o clima imprimiriam sobre seus povos. Assim, o modo de ser dessas alteridades europeias foi sendo vinculado, não sem reiterar as muitas outras camadas discursivas de sua inferiorização, aos efeitos supostamente danosos das altas temperaturas sobre os organismos. As implicações dessas concepções no imaginário ocidental podem ser até hoje identificadas, quando mencionam, por exemplo a sensualidade como característica inerente aos povos de lugares marcados por climas quentes, ou quando comentam acerca de uma maior predisposição das pessoas que habitam países frios para a atividade intelectual.

Aliás, o determinismo ao qual a letra de Caravanas faz referência, guarda relação com a crítica de Buffon à taxionomia de Lineu. Se com Lineu os tipos 
humanos estavam classificados em estreita relação com os continentes de origem, em Buffon eles seriam suscetíveis, tanto física quanto psicologicamente, aos estímulos aos quais fossem expostos ao longo da vida, à medida em que se deslocassem, ou entrassem em contato com outros povos. Essa percepção não eliminaria a noção de que alguns tipos seriam superiores a outros, mas introduziria a ideia de que as raças consideradas inferiores poderiam ser aperfeiçoadas pelo contato com o branco/europeu, dito mais "ágil, perspicaz e inventivo."1 Daí o entendimento compartilhado pelos letrados do mundo ibérico, de que caberia aos de aparência branca a responsabilidade de civilizar índios e africanos, de modo que fossem afastados dos hábitos e das atitudes que, na compreensão dos europeus, os identificavam à barbárie. ${ }^{2}$

Talvez seja importante elucidar que a ideia de raça é uma construção que obedece à lógica da nomeação da diferença. Ela tem como premissa a suposta constatação de que a natureza haveria criado tipos humanos distintos, dotados de características físicas e psicológicas próprias. Tal racialização da humanidade não antecede, como pode parecer, ao racismo. Ou melhor, antecede sim, mas só à formulação do termo, do qual se tem os primeiros registros entre o final do século XIX e o iniciar do XX. O conteúdo do racismo pode ser percebido muito antes de ter sido assim definido. Nesse sentido, cabe ressaltar que apesar da ideia de raça ter sido gestada pela modernidade europeia, o racismo não constitui prática exclusiva dos europeus, ou dos que se identificam como brancos. Por isso mesmo, parece ser mais apropriado falar em racismos no plural, uma vez que as práticas discriminatórias em relação ao outro foram protagonizadas, ao longo do tempo, por diversos grupos, em diversas circunstâncias. Assim, se faz imprescindível sinalizar que o amplo espectro de legitimação discursiva de uma pretensa superioridade branca/europeia não é a única expressão do racismo, mas sim uma de suas tantas manifestações, ou melhor, uma das expressões possíveis dos racismos, no plural. Com efeito, a própria invenção da ideia de raça pelos europeus no XVIII serve à legitimação de preconceitos que compartilhavam em relação às suas alteridades. Essa mesma ideia de raça, cunhada no seio do racionalismo branco ilustrado, serviu também para subterfugiar uma série de outras disputas relacionadas ao poderio

\footnotetext{
${ }^{1}$ BETHENCOURT, Francisco. Racismos. São Paulo, Companhia das letras, 2018, p.345.

2 TODOROV, Tzvetan. Nós e os outros: a reflexão francesa sobre a diversidade humana. Rio de Janeiro: Jorge Zahar Ed., 1993.
} 
econômico e político, na medida em que as hipotéticas predisposições das raças justificavam a dominação de uns sobre os outros, nesse caso, a dominação de europeus sobre americanos e sobre africanos. ${ }^{3}$

De todo modo, aqui nos cabe precisar a relação entre esse amplo arcabouço discursivo, que colateralmente acabava contribuindo para reiterar uma série de preconceitos já disseminados pelos que se identificavam como brancos, e o nosso objeto: os escritos de letrados que pensaram o Brasil como pátria independente e como nação original na esteira do projeto de independência que viria a se tornar o vencedor. Pois bem, a questão que nos chamava a atenção desde os primeiros movimentos dedicados a pensar esta tese, era a de que, embora não fosse óbvia, havia uma dimensão racialista incutida no discurso civilizatório orientador das ideias dos autores do establishment. No decorrer da pesquisa, fomos nos dando conta de que os argumentos construídos por esses letrados, para justificar racialmente a submissão dos que chamavam índios e negros, dialogavam, em muito, não só com a secular tradição discursiva de hierarquização dos povos, mas também com os desdobramentos e ressignificações dessa tradição pela razão ilustrada, que havia se encarregado, ainda antes de Buffon e Montesquieu, de definir os seres humanos a partir de classificações raciais. É, portanto, às sobrevivências dessas concepções de raça e de inferiorização dos povos não europeus, nos escritos dos letrados do Brasil independente, que chamamos retórica racialista. Uma retórica racialista que não é absoluta e tampouco única e, por isso mesmo, precisa ser demarcada em sua especificidade, precisa estar associada aos nuançados discursos de uma branquitude que, por séculos, fez seu modus operandi ser percebido, sobretudo no mundo Atlântico, como universal.

Aliás, o conceito de branquitude vem sendo discutido por estudiosos anglófonos pelo menos desde meados do século XX e vem ganhando força em outros espaços do globo, revelando as peculiaridades que o termo pode evocar em diferentes locais e conjunturas, há pelo menos duas décadas. ${ }^{4} \mathrm{O}$ crescimento da

\footnotetext{
3 Tais reflexões derivam de uma combinação de leituras. Sobre esses temas e abordagens, ver: BETHENCOURT, Francisco. Racismos. São Paulo, Companhia das letras, 2018; Ver: FIELDS, Barbara J. \& FIELDS, Karen E. Racecraft. The Soul of inequality in American Life. Verso: NY, 2012; ver: MBEMBE, Aquille. Crítica da razão negra. N-1 Edições, 2018; ver: TODOROV, Tzvetan. Nós e os outros: a reflexão francesa sobre a diversidade humana. Rio de Janeiro: Jorge Zahar Ed., 1993.

${ }^{4}$ Entre os pioneiros do campo estão William E.B. Du Bois, Theodore W. Allen, Ruth A.E. Frankenberg e David Roediger. No Brasil, um dos primeiros estudos a tocar na questão e a discutir as especificidades do que significaria branquitude no país, foi o trabalho organizado por Maria
} 
problematização e dos usos do termo branquitude, por si só, já corresponde a uma espécie de reorientação do olhar sobre os estudos dedicados a investigar as questões raciais, que até então abordavam apenas as alteridades não-europeias como sujeitos racializados, corroborando assim o entendimento profundamente arraigado do branco como sujeito padrão e, portanto, destituído de raça. ${ }^{5}$ No Brasil, onde as configurações da questão racial estão atravessadas por um entendimento todo peculiar do que significa ser branco, os estudos sobre branquitude vem ganhando espaço sobretudo no campo da Psicologia Social, ${ }^{6}$ sendo ainda um conceito timidamente abordado pela historiografia, sobretudo por aquela que pretende historicizar e discutir o próprio campo, a chamada História da Historiografia. $\mathrm{Na}$ Psicologia Social, o tema ganha importância à medida em que passa a indicar a relevância de se reconhecer o marcador racial como constitutivo da psique dos sujeitos, pois os pesquisadores da área defendem que, para além dos já considerados marcadores de gênero e de classe, é preciso que os marcadores raciais sejam igualmente reconhecidos como determinantes da constituição psíquica do indivíduo. Isto porque, a cor/raça com a qual a pessoa se identifica, e é identificada, interferem tanto na constituição dos sujeitos historicamente inferiorizados, como também na dos que por se reconhecerem e serem reconhecidos como brancos acabam se beneficiando, mesmo que involuntariamente, de uma série de privilégios. ${ }^{7} \mathrm{Na}$ Historiografia brasileira, embora haja um campo consistente de debate em torno dos usos do termo raça, não é comum que nos deparemos com trabalhos que interajam com a problematização levantada pelo conceito de branquitude, qual seja, a problematização acerca dos discursos produzidos por aqueles que se percebem brancos e assim interagem com toda uma herança retórica que forjou, por diversos meios, a noção de superioridade branca. A área da

Aparecida Silva Bento e Iray Carone, publicado em 2002. Ver: BENTO, Maria Aparecida Silva. \& CARONE, Iray. Psicologia social do racismo. Estudos sobre branquitude e branqueamento no Brasil. Petrópolis, RJ: Editora Vozes, 2002.

${ }^{5} \mathrm{O}$ estudo de Vron Ware, originalmente intitulado Whiteness: White identity and multiculturalismo, foi um dos primeiros estudos sobre branquitude a ser traduzido para o português. Ver: WARE, Vron. Branquidade: identidade branca e multiculturalismo. Rio de janeiro: Garamond, 2014.

${ }^{6}$ Conforme citado anteriormente, um dos estudos pioneiros sobre o tema é o livro organizado por Maria Aparecida Bento e Iray Carone. Ver: BENTO, Maria Aparecida Silva. \& CARONE, Iray. Psicologia social do racismo. Estudos sobre branquitude e branqueamento no Brasil. Petrópolis, RJ: Editora Vozes, 2002.

7 SCHUCMAN, Lia Vainer. Entre o "encardido", o "branco" e o "branquíssimo": raça, hierarquia e poder na construção da branquitude paulistana. São Paulo: Veneta Editora, 2020. 
Historiografia que mais se aproxima da discussão é a História da Ciência, que há anos vem produzindo trabalhos que demonstram como a própria ciência contribuiu para endossar o consenso discursivo da branquitude. De todo modo, consideramos haver ainda uma brecha importante a ser preenchida, sobretudo se pensarmos o campo da História da Historiografia em associação com a abordagem da História Intelectual: a da problematização dos escritos fundadores da ideia de Brasil, de nação brasileira e de brasileiro como textos assinados por sujeitos que compartilhavam o pertencimento ao mundo branco/europeu/civilizado. O que esta tese propõe é que o estudo das ideias deixe de naturalizar os autores de época como membros de uma certa elite intelectual, educada nas universidades europeias e vinculada aos interesses econômicos senhoriais, como se a cor da pele e os benefícios dela decorrentes fossem casuais. Consideramos ser necessário nomear e discutir os efeitos da construção social da identidade branca nesses autores, pois em seus papéis há elaborações que seriam inviáveis não fosse a adesão, por vezes inconsciente, desses sujeitos aos códigos da branquitude. Nesse sentido é que nos interessa pensar sobre o impacto dessa retórica racialista da branquitude ainda na origem da definição do Estado e da subjetividade do país. Uma dimensão do discurso pátrio e nacional, que se mostra indispensável ao entendimento das matrizes de um imaginário que ainda hoje subjuga, explícita e sutilmente, de modo geral os não-brancos e, de modo mais agressivo os que são apontados como negros.

Contudo, há ainda de se fazer aqui algumas observações de suma importância, norteadoras de toda a escrita desta tese. Quando problematizamos questões que envolvem temas como os nossos, é imprescindível escrever com cautela para que não incorramos em naturalizações. Por isso, todos os termos referentes a marcadores raciais de identificação são, ao longo de todo o trabalho, grifados em itálico. Essa foi uma das estratégias que encontrei para que a minha própria escrita não legitimasse alguns dos indícios linguísticos derivados, sob muitos aspectos, da construção retórica da racialização do outro pelo branco, enquanto sujeito universal. Assim, como que tentando denunciar esse universalismo, opto por demarcar também o branco como sujeito racializado, mas sem perder de vista que, não apenas esse como todos os termos encarregados de discernir racialmente determinado contingente de pessoas, constituem construções discursivas que suprimem as diferenças étnicas em prol da criação de uma identidade fenotípica. Aliás, o próprio branco ibérico ao se autorreferenciar como 
tal, suprimia as múltiplas origens étnicas que o constituíam, o que ilustra, ao menos em parte, a lógica da estratégia retórica de produção de identidades raciais. Cabe observar ainda que, quando utilizamos os termos negro e índio, os grifamos porque, além estarmos cientes de que reproduzem a racialização no discurso, entendemos que são termos forjados pela modernidade branca europeia diante da demanda por definir suas mais expressivas alteridades no mundo atlântico. Pelo mesmo motivo, procurei evitar o uso da alcunha nativo, mas quando se fez necessário utilizá-la foi porque a intenção era, justamente, a de assinalar a condição dos povos originários ao se perceberem destituídos de seu próprio espaço pelos colonizadores europeus. ${ }^{8}$

Problematizar abordagens de letrados intimamente ligados ao Estado, em suas primeiras articulações pela definição da unidade pátria, e investigar os usos e as apropriações que realizaram das noções racialistas em circulação, constitui o objetivo desta tese. Tese que também pretende contribuir para o debate sobre as tantas especificidades que marcaram a construção de um país, onde ainda ecoam concepções racistas muito peculiares. Isto posto, passamos a apresentação dos capítulos.

Abro o primeiro Capítulo, intitulado Diagnósticos e horizontes de um Estado em definição, discutindo o engendramento das camadas discursivas constitutivas da complexa retórica de hierarquização dos povos e sua reapropriação pela razão ilustrada. Nesse primeiro momento do capítulo me dedico a apresentar as tensões presentes no mundo atlântico, em especial aquelas provocadas pelo empreendimento colonial, problematizando-as frente ao cabedal discursivo de hierarquização dos povos com o qual dialogavam. Nesse momento do capítulo, já começo a estabelecer pontes entre esse legado da colonização, seu entendimento mais geral sobre o índio e negro, e as observações mais preliminares de José Bonifácio, ainda antes da Independência, sobre o que entendia ser a necessidade de civilizar os índios e superar a escravidão de negros. O Capítulo segue, colocando em questão os desdobramentos da Revolução Liberal do Porto na esfera pública da Corte, debatendo, com especial atenção, as ressignificações das noções singularizadas de pátria e de povo, que passavam a ganhar espaço e começavam a invocar a ideia de autonomia em relação a Portugal. Na última parte do capítulo, os esforços se concentram em analisar a dimensão racialista da escrita de José

\footnotetext{
${ }^{8}$ Tais observações não teriam sido elaboradas sem a leitura da obra de Aquille Mbembe. Ver sobretudo: MBEMBE, Aquille. Crítica da razão negra. N-1 Edições, 2018.
} 
Bonifácio, sobretudo no que se apresenta a partir de dois textos seus oferecidos à Assembleia Constituinte de 1823, intitulados: Apontamentos para a civilização dos índios bravos do Império do Brasil e Representação sobre a escravatura.

No Capítulo nomeado pela indagação Quem constitui a paleta local?, enfrento o debate sobre a origem do Romantismo, priorizando, no primeiro momento do capítulo, a interessante discussão sobre a leitura crítica realizada pelo Romantismo francófono dos cânones ilustrados. Procuro demonstrar como esse movimento, simultaneamente de crítica e de apropriação, reinventaria o olhar europeu sobre o Novo Mundo, positivando, assim, o olhar sobre a paisagem, mas reiterando, por outras entradas, a inferiorização de seus habitantes não-brancos. $\mathrm{Na}$ sequência, desenvolvo o significado da ideia de originalidade intelectual que pautou a publicação da Nitheroy Revista Brasiliense, considerada fundadora do Romantismo no Império do Brasil e destaco o posicionamento crítico dos redatores da Revista em relação ao que consideravam a nefasta herança da colonização, sobretudo no que tangia à permanência da escravidão. O Capítulo termina discutindo, justamente, a presença de concepções racialistas nos escritos de Domingos José Gonçalves de Magalhães e de Francisco Salles Torres-Homem. Demonstro como os usos feitos das noções racialistas se conjugavam, na escrita desses românticos, à invenção do índio virtuoso, forjado como primeiro Brasileiro, e também à clássica retórica do liberalismo antiescravista. Usos esses que, no entanto, reafirmavam, por novas vias, aquelas mesmas noções já presentes em Bonifácio, de que índios e negros ocupariam patamares raciais e civilizacionais anteriores aos ocupados pelos que se entendiam como brancos.

O último capítulo, Um Estado, uma História, um povo: aparente unidade, se propõe a discutir, de início, as questões imbricadas na ascensão do grupo do Regresso às esferas decisórias de poder, considerando as acepções racialistas balizadoras das falas de um de seus mais expressivos idealizadores: Bernardo Pereira de Vasconcelos. Procuro demonstrar como a questão do tráfico e do escravismo em si adquiriu importância central em sua retórica e como o arcabouço teórico racialista e a retórica liberal foram mobilizadas por este que foi um dos poucos oradores a positivar a prática escravista. No curso do Capítulo, analiso a fundação do IHGB e discuto o seu lugar nessa rede de poder da sede do Império. A partir de alguns dos textos desenvolvidos por Januário da Cunha Barbosa, redator do Revérbero Constitucional Fluminense na década de 1820 e fundador e Secretário 
Perpétuo do IHGB, problematizo as nuances racialistas de seu discurso antiescravista, e debato a sua proposta de que os índios fossem utilizados como alternativa à mão-de-obra de origem africana. O Capítulo se encerra com uma discussão que também teve lugar no IHGB: a discussão sobre a escrita de uma História do Brasil, uma História com H maiúsculo, uma História da unidade pátria que o Império do Brasil pretendia forjar. Nesse momento final da tese, investigo os debates travados pelos letrados associados ao IHGB acerca da definição das épocas dessa História do Brasil que pretendiam escrever. Reflito sobre como essa narrativa de uma História única, de intenções nacionalizantes, constituía, sob muitos aspectos, o lugar narrativo da branquitude luso-americana. A partir do conhecido texto de K.F.P. von Martius, sugestivamente intitulado Como se deve escrever a História do Brasil, proponho uma análise do diálogo que esse texto trava com o arcabouço racialista em voga e sinalizo a guinada dada pelo botânico bávaro ao singularizar a diversidade étnica dos habitantes do Brasil, aventando a ideia de um povo brasileiro mesclado.

A escolha desses autores não foi eventual. Reconhecemos serem autores que falam como chanceleres intelectuais de um projeto de Estado que se consolidou pela violência, pela manutenção do escravismo e pelo apagamento e/ou pela diluição dos habitantes que, por seus traços físicos e morais, eram vistos como indesejáveis. Por isso mesmo a escolha, porque seus textos manifestam os usos que fizeram da retórica racialista na diacronia da configuração de um país novo, que então se definia na dimensão da sincronia que experienciavam. Os três momentos abordados na tese, e que não por acaso correspondem à organização dos capítulos, para além serem determinados por um conjunto de circunstâncias específicas a cada um deles, parecem ser atravessados por um fio que os conecta entre si. Um fio que é possível enxergar à medida em que se evidenciam as interações entre um momento e outro, entre um autor e outro. Esperamos dar a ver esse fio que, de algum modo, se estende até os dias atuais. 


\section{Diagnósticos e horizontes de um Estado em definição}

Tudo é questão de saber até onde se estende o território da identidade e onde começa o da diferença. ${ }^{9}$

TzvetanTododrov

${ }^{9}$ TODOROV, Tzvetan. Nós e os outros: a reflexão francesa sobre a diversidade humana. Rio de Janeiro: Jorge Zahar Ed., 1993. 


\subsection{Das diferenças e dos discursos hierarquizantes}

A fundação do Brasil independente está, assim como tantas outras experiências latino-americanas coetâneas, atravessada por um componente determinante dos Estados que se configuraram na esteira do legado do colonialismo: a coexistência de distintos povos, então racialmente diferenciados. Diferenciações essas, que correspondiam a hierarquizações legitimadas, em diversas instâncias discursivas, pela retórica da superioridade dos identificados como brancos em relação aos demais.

Pilar do colonialismo ibérico, a retórica de hierarquização dos povos acabaria por se converter em um problema a ser enfrentado pelas lideranças emancipatórias, não por acaso, majoritariamente autorreferenciadas como brancas. Uma questão que se impunha à medida em que as distinções raciais e os disparates jurídicos que as refletiam, passavam a constituir um entrave às aspirações por unidade territorial e por coesão populacional, tão características dos Estados-nação oitocentistas.

Os escritos de José Bonifácio apresentados à Constituinte de 1823, pioneiros em abordar o que lhe parecia a problemática da heterogeneidade da população, já enunciavam, em suas entrelinhas, quem eram os outros do Brasil independente. Os identificados por Bonifácio como índios e como negros são problematizados em seus textos enquanto coadjuvantes de um país orquestrado por brancos, que se percebiam herdeiros morais e fenotípicos dos europeus. Percepção que os investia de uma retórica civilizatória capaz de endossar a sua suposta superioridade, comunicando a índios e negros que seus modos de existir seriam inadequados. Os letrados e civilizados que se diziam pertencentes à boa sociedade, ao se auto responsabilizarem por aperfeiçoar aqueles que consideravam inferiores, ressignificavam os usos de uma ampla e versátil retórica hierarquizadora dos povos, colocando-a, então, a serviço das especificidades de um país alicerçado pelo escravismo.

As diferenças físicas entre os povos há muito inquietam e há muito se desdobram em verdades hierarquizantes. No Antigo Testamento, o livro do Gênesis, de certa forma, já buscava entender essas distinções através de uma espécie de nivelamento. Nele se afirma que os povos do mundo descenderiam de três 
troncos ancestrais, personificados nas figuras dos três filhos de Noé: Sem, Cam e Jafé, supostamente encarregados de refundar a raça humana após o dilúvio. ${ }^{10}$ De acordo com essa tradição, os povos do Norte seriam descendentes de Jafé, os povos semitas - entre eles árabes e judeus - seriam descendentes de Sem, e os povos do Sul e do Leste seriam os descendentes de Cam. Ocorre que esse último filho de Noé, segundo o livro sagrado, teria cometido uma espécie de indiscrição - ou mesmo de violação - contra o corpo adormecido de seu pai. Em função disso, Noé teria amaldiçoado todos os descendentes de Cam à servidão eterna. ${ }^{11}$ Os descendentes de Cam seriam, portanto, os povos da África e da Ásia. As interpretações que se desdobraram desse texto, direcionariam uma série de reapropriações que iriam definir a percepção dos judaico-cristãos sobre si e sobre os seus outros. Leituras que serviriam muito convenientemente, ao longo de séculos, para justificar a postura dos povos do Norte, que viriam a ser nomeados europeus, em relação, sobretudo, aos povos meridionais de que tinham conhecimento.

Uma das primeiras vozes do cristianismo a interpretar a dita Maldição de Cam como uma espécie de prelúdio às práticas escravistas foi a de Agostinho. ${ }^{12}$ Práticas que, por sua vez, remontam à Antiguidade e que foram sempre amparadas por justificativas que as investiam de legitimidade. Aliás, em Aristóteles o escravismo era aceito e justificado, sob o argumento de que reproduzia uma relação natural de subordinação, tal como ocorreria entre pai e filho. Na esteira do entendimento de que a escravização era inerente à natureza humana, consideravase que determinados seres humanos seriam, por deficiência na beleza e na virtude da alma, ${ }^{13}$ intrinsecamente propícios a serem escravizados. Inclusive, se fosse necessário o uso da violência para submetê-los à tal condição, a guerra seria considerada uma guerra justa. Releituras dessa tradição aristotélica, como a

\footnotetext{
${ }^{10}$ BETHENCOURT, Francisco. Racismos: das Cruzadas ao século XX. São Paulo: Companhia das Letras, 2018, p.99.

${ }^{11}$ Cabe salientar que a ideia de escravidão, na Bíblia, está associada à noção de viver em pecado. A esse respeito, ver: FREITAS, Ludmila Gomides. Princípios Jurídicos na Colonização do Novo Mundo: O debate sobre a escravidão indígena nas Américas portuguesa e espanhola. Passagens. Revista Internacional de História Política e Cultura Jurídica. Rio de Janeiro: vol. 7, no.3, setembrodezembro, 2015, p. 456-472. Ver tembém: PINAR, William F. O corpo do pai e a raça do filho: Noé, Schreber e a maldição do pacto. Revista Brasileira de Educação v. 13 n. 37 jan./abr. 2008, p. 35-6.

${ }^{12}$ FREITAS, Ludmila Gomides., op.cit., p.460.

${ }^{13}$ Ibid., p.459.
} 
realizada por São Tomás de Aquino, ${ }^{14}$ passariam a legitimar a escravidão apenas no seu aspecto material, ponderando, assim, a noção de que os escravizados possuiriam uma predisposição espiritual a tal condição. De acordo com a tradição tomista, portanto, embora a escravidão continuasse a se justificar por uma condição inata de determinados grupos, se passava a repercutir a ideia de que a alma dos cativos permaneceria livre, sempre, mesmo quando no mundo do real seus corpos estivessem submetidos. Tal entendimento refletia o postulado acordado pela teologia medieval de que - à revelia do legado aristotélico - os seres humanos seriam, em última instância, todos iguais, porque filhos de Deus. ${ }^{15}$

A partir do contato com as Américas e da decisão real por colonizar esses territórios, os pensadores ibéricos foram impelidos a rearticular seu cabedal teológico-filosófico, principalmente porque a conquista em curso dava sinais de que os povos americanos seriam potenciais vítimas da escravidão. Passava a pairar, então, sobre os juristas e filósofos seiscentistas algumas indagações, sobretudo em relação ao estatuto dos habitantes do Novo Mundo: seriam bárbaros? Degenerados? Ou deveriam ser encarados como súditos da Coroa?

Não sem motivo, os argumentos legitimadores do escravismo se reconfigurariam a partir da expansão ultramarina e da decorrente ampliação dos horizontes europeus sobre a gama de povos que coexistiam sobre a Terra. Em meio às conquistas, foram sendo atualizadas as impressões que os hipotéticos descendentes de Jafé faziam dos demais povos, sobretudo dos que haveriam sido amaldiçoados em sua origem. A iconografia renascentista serviria a esse propósito, produzindo obras que reordenavam os povos, apresentando uma espécie de hierarquização dos continentes, em um mundo de proporções mais alargadas. ${ }^{16} \mathrm{Em}$ um frontispício esculpido nos arredores de 1570, nomeado Theatrum Orbis Terrarum, a Europa aparecia alçada ao topo, enquanto Ásia e África - já conhecidas - ocupavam posições intermediárias. A América - inteiramente nova - aparecia, então, em posição diametralmente oposta à Europa, no mais inferior dos patamares.

\footnotetext{
${ }^{14}$ GUTIERREZ, Jorge Luis. A controvérsia de Valladolid (1550): Aristóteles, os índios e a guerra justa. Revista USP, São Paulo, nº101, p.223-235. MAR/ABR/MAI 2014.

15 FREITAS, Ludmila Gomides. Princípios Jurídicos na Colonização do Novo Mundo: $O$ debate sobre a escravidão indígena nas Américas portuguesa e espanhola. Passagens. Revista Internacional de História Política e Cultura Jurídica Rio de Janeiro: vol. 7, no.3, setembrodezembro, 2015, p. 456-472, p.460.

${ }^{16}$ BETHENCOURT, Francisco. Racismos: das Cruzadas ao século XX. São Paulo: Companhia das Letras, 2018, p.104; 110.
} 
Importante notar que esse tipo de alegoria dos continentes comumente se valia de figuras humanas para representá-los. E essas figuras apareciam ornadas por elementos que expressavam a perplexidade com a qual o branco/ europeu enxergava os continentes e os povos que lhe eram alheios. África e América, embora alocadas em patamares distintos, surgem, neste mesmo frontispício, desnudas, enquanto Europa e Ásia, vestidas. A obra comunica, ainda, uma série de outros estereótipos, quando, por exemplo, apresenta a figura europeia com um cetro nas mãos e a americana segurando a cabeça de um homem branco, assim, vinculando uns à ideia de justiça e outros à noção de brutalidade. ${ }^{17}$ Estereótipos que, no fluir dos séculos, seriam refinados e atualizados pela filosofia, pela ciência, pelas artes e pelos demais espaços discursivos criados por aqueles que foram convertendo a sua verdade em verdade universal. ${ }^{18}$

A Escola de Salamanca se tornaria referência nesse debate acerca do estatuto dos povos americanos. Por anos seguidos, os teólogos e filósofos a ela filiados discutiriam a questão a partir dos relatos de missionários recém chegados da América. Uma realidade inteiramente nova se colocava, então, diante desses pensadores formados na tradição teológico-filosófica tributária de São Tomás de Aquino. De Salamanca surgiram proposições que, sem deixar de reproduzir a retórica da superioridade do continente europeu, atestavam a condição de barbárie dos povos americanos e, ao mesmo tempo sinalizavam na direção da possibilidade de conversão desses povos. Isso refletia uma espécie de consenso dos dominicanos de Salamanca em torno da negação da noção aristotélica de escravidão natural. ${ }^{19}$ Entendimento que os permitia repercutir a ideia de que o estado de barbárie dos que chamavam índios seria reversível, desde que introduzidos à fé cristã. A imposição do modo de existir europeu se daria, então, através da cristianização desses povos, vistos como bárbaros em suas maneiras de se alimentar e de praticar a espiritualidade, porque maneiras outras, maneiras alheias ao que a padronização judaico-cristã vinha definindo como humanidade.

\footnotetext{
${ }^{17}$ Francisco Bethencourt analisa diversas dessas alegorias hierarquizadoras dos continentes e de seus povos. Ver: BETHENCOURT, Francisco. Racismos: das Cruzadas ao século XX. São Paulo: Companhia das Letras, 2018, p.104.

18 TODOROV, Tzvetan. Nós e os outros: a reflexão francesa sobre a diversidade humana. Rio de Janeiro: Jorge Zahar Ed., 1993.

${ }^{19}$ SILVA, Rodrigo Henrique Ferreira da. A linguagem política do bom governo nas leis novas: Francisco de Vitoria e o tomismo espanhol, 1493-1543. Dissertação de Mestrado. UNESP. Franca, 2016.
} 
Frei Bartolomé de Las Casas (1484-1566) seria um nome de peso nessas disputas retóricas pelo enquadramento dos povos americanos no arcabouço hierárquico compartilhado pela tradição judaico-cristã. Sua argumentação, em muito derivada da atualização da herança tomista e dos debates de Salamanca, consistia na denúncia do caráter violento e desumano das incursões hispânicas e do que considerava expressar o distanciamento entre essas práticas e os valores cristãos. Em 1552, Las Casas publicaria suas impressões ${ }^{20}$ a respeito das atrocidades que havia presenciado como bispo em Chiapas. ${ }^{21}$ Essa sua obra organizaria uma espécie de reação intelectual às ideias de Juan Guinés de Sepúlveda (1494-1573), partidário da noção de que os índios se enquadrariam no conceito de barbárie definido por Aristóteles. ${ }^{22}$ Ocorre que n'A Política, a barbárie possuía níveis distintos, regulados por predisposições inatas: uns nasceriam para a submissão e outros para a governança. ${ }^{23}$ A despeito das diferenciações estabelecidas por Aristóteles, Sepúlveda afiançava que a condição generalizada de barbárie dos povos do Novo Mundo permitiria a sua escravização justa. ${ }^{24} \mathrm{Em}$ contrapartida, Las Casas sugeria que a submissão dos índios aos colonizadores se realizasse pelo viés da persuasão e não mais pela dominação violenta. A querela Las Casas versus Sepúlveda alcançaria enorme repercussão e contribuiria, com efeito, para reiterar a sujeição desses povos e naturalizar a sua inferioridade, evidenciando que as divergências se davam apenas em relação à forma pela qual exerceriam a dominação. De qualquer modo, os argumentos de Las Casas e Sepúlveda reverberariam por séculos, inspirando elogios e críticas aos projetos colonizadores implementados nas Américas, alimentando as disputas discursivas em torno ou da condenação, ou da legitimidade do uso da violência para com os povos americanos, sem, no entanto, inspirar questionamentos relativos à submissão dos índios em si.

\footnotetext{
20 A obra em questão é a Brevísima Relación de la Destrucción de las Indias. A esse respeito, ver: GUTIERREZ, Jorge Luis. A controvérsia de Valladolid (1550): Aristóteles, os índios e a guerra justa. Revista USP, São Paulo, nº101, p.223-235. MAR/ABR/MAI 2014, p.227-8.

${ }^{21}$ Bartolomé de Las Casas desempenhou, ainda no século XVI, a função de missionário em Chiapas, atual México.

${ }^{22}$ Sepúlveda havia estudado com um dos maiores especialistas na obra de Aristóteles, o filósofo renascentista Pomponazzi (1462-1525). A esse respeito ver: GUTIERREZ, Jorge Luís., op.cit., p.22 ${ }^{23}$ FREITAS, Ludmila Gomides. Princípios Jurídicos na Colonização do Novo Mundo: O debate sobre a escravidão indígena nas Américas portuguesa e espanhola. Passagens. Revista Internacional de História Política e Cultura Jurídica Rio de Janeiro: vol. 7, no.3, setembrodezembro, 2015, p. 456-472, p.459.

${ }^{24}$ GUTIERREZ, Jorge Luis., op.cit., p.226.
} 
O jesuíta José de Acosta (1540-1600) seria um dos que dariam continuidade à contenda encampada por Las Casas e Sepúlveda, assumindo uma vertente interpretativa que se beneficiava de ambas as contribuições. Para Acosta, o uso da força seria legítimo nas ocasiões em que os missionários se deparassem com povos que praticassem sacrifícios humanos, o que corroborava a noção, já em difusão pelo menos desde Colombo, de que o chamado canibalismo poderia ser combatido com caçadas, torturas e escravização. ${ }^{25}$ A tese do jesuíta era a de que o barbarismo estava relacionado ao espaço geográfico e que o ambiente determinaria os hábitos alimentares, os modos de vestir e até as práticas religiosas. Sua compreensão era a de que a condição de barbárie poderia ser distinguida em três níveis, problematizando, assim, o pensamento de Sepúlveda a respeito da invariável licitude da guerra contra os que nomeavam índios. De acordo com Acosta, o nível mais grave de barbarismo seria aquele definido pela noção de selvagem, então associada ao nomadismo, à nudez e, eventualmente, ao canibalismo; o nível intermediário seria aquele onde estariam os povos iletrados que, apesar disso, conseguiam se organizar politicamente e estabelecer um corpo de governo e um corpo de magistrados, como seria o caso dos mexicas e dos incas; e haveria o nível de barbárie menos comprometido pela animalidade, que seria o dos bárbaros racionais, no qual se encaixariam japoneses, chineses e indianos. ${ }^{26}$ Acosta enuncia, assim, uma ideia que ajudaria a redefinir as justificativas mobilizadas pela retórica da inferiorização das alteridades europeias, que eram também as alteridades ao monoteísmo judaico-cristão. Não por acaso, de acordo com o nivelamento proposto, o quesito responsável por manter o enquadramento dos asiáticos na categoria da barbárie era justamente o relativo às suas práticas religiosas. O modo politeísta de encarar a espiritualidade era entendido, então, como o fator desabonador dos asiáticos. Mesmo sendo reconhecidos por terem desenvolvido governos estáveis, comércio e letramento - então chancelados como índice de humanidade e de racionalidade pela tradição europeia - japoneses, chineses e indianos, embora considerados menos selvagens que os americanos, continuavam a ser vistos como bárbaros. Como que em uma atualização da longa tradição de inferiorização dos povos do Sul e do Leste, a condição de barbárie se complexificava pelo

\footnotetext{
${ }^{25}$ BETHENCOURT, Francisco. Racismos: das Cruzadas ao século XX. São Paulo: Companhia das Letras, 2018, p.148.

26 Ibid., p.121.
} 
estabelecimento de gradações. O cabedal com o qual operavam passava, assim, a abarcar as novas alteridades apresentadas a partir do contato com a América, situando-as em relação às noções de barbárie e de racionalidade que compartilhavam.

As ressignificações originadas das sobreposições dessas camadas discursivas e a interação dessas ideias com os imperativos colocados pelo empreendimento colonial foram encaminhando o entendimento de que, talvez, não fosse conveniente insistir na escravização dos indígenas. $\mathrm{Na}$ esteira do debate teológico-filosófico ibérico, as autoridades reais pareciam se inclinar cada vez mais em direção ao reconhecimento da humanidade dos índios e à chance que haveria de os cristianizar. A isso se somavam os relatos de europeus que enxergavam comportamentos preguiçosos na relação harmônica dos povos originários com seu ambiente, contribuindo para a formulação do estereótipo do índio indolente. Por fim, a conveniência em declará-los vassalos do rei e se apossar persuasivamente de suas terras prevaleceria à opção por dominá-los pela violência e escravizá-los indiscriminadamente no seu próprio lugar.

À propósito, cabe observar que na trajetória do escravismo, quanto mais se operou o despojamento do escravizado de seu lugar de origem e o consequente rompimento de suas referências espaciais e familiares, maior foi o controle exercido pelos escravizadores e menores foram as chances, sobretudo no curto prazo, de resistência e insubordinação por parte dos que se viam esvaziados de referências e violados em sua vontade. No desdobrar dessa discussão, os índios, quando comparados aos negros, foram sendo retratados pela retórica colonizadora como menos suscetíveis ao escravismo. Sem deixar de os julgar inferiores e reiterando uma série de estereótipos ligados a ideia que compartilhavam de selvageria, o cabedal discursivo que amparava o colonialismo ibérico se encarregaria de estabelecer que os índios seriam investidos de status jurídico similar ao dos brancos. Isto é, reconheciam a humanidade dos índios - superando assim as noções que os enquadravam na chave da animalidade - e declaravam ilegítima a sua escravização, deixando em aberto alguns precedentes. Assim, comportamentos associados ao canibalismo, ou mesmo o que considerassem insubordinação, ou resistência à evangelização acabavam se convertendo, na prática, em brechas dessas legislações para que o colonizador europeu continuasse a escravizar, eventualmente, aquele que identificasse como índio. 
Em se tratando da importância que o modelo de plantation passava a adquirir para o projeto colonizador português na América, a demanda por mão-de obra se colocava como um imperativo a esses sujeitos pautados pela noção de que os trabalhos indesejáveis deveriam ser executados por aqueles que viam como inferiores. Na impossibilidade de escravizar sistematicamente os índios, os então declarados negros, passaram a constituir uma possibilidade, à medida em que negociantes da costa africana se dispuseram a vender grupos de pessoas, circunstancialmente aprisionadas e escravizadas em função de desavenças locais, a atravessadores atentos à necessidade de mão-de-obra reclamada pelos colonos da outra borda do oceano. ${ }^{27} \mathrm{~A}$ complexa rede atlântica de comércio humano que se estabeleceria a partir daí, fundando novas e variadas hierarquizações entre índios e negros nas Américas, se encarregaria de fornecer um contingente de pessoas alijadas de sua terra, de seus hábitos e de seu pertencimento coletivo para serem escravizadas com a chancela teológico-filosófico-jurídica substanciada pelo discurso da superioridade física e moral dos que se diziam brancos/europeus.

A partir do século XVIII, a consolidação da ideia de progresso passaria a se sobrepor à noção, até então compartilhada, de que o saber estava na Antiguidade $\mathrm{e}$ de que o tempo presente seria um tempo de decadência. O tempo das similitudes, ou o modo imitativo de interpretar o mundo à luz dos saberes clássicos ia sendo, então, ressignificado por novas descobertas, por novos saberes. Iam se abrindo, assim, novos espaços para a produção de novos significados. As tantas academias de ciências, letras e artes inauguradas entre as décadas finais do XVII e iniciais do XVIII testemunham isso. A esses espaços se associariam sujeitos motivados a observar e a descrever, uma vez que a realidade parecia não mais ser explicável pela tradição clássica. Era preciso olhar tudo de novo, interpretar tudo de novo, reler o mundo. ${ }^{28}$

Não que os saberes antigos tenham sido inutilizados, mas deixaram de ser suficientes. Esse novo modo de olhar, de perceber e de explicar o mundo constituía um devir essencialmente europeu, essencialmente identificado à produção da verdade dos que se percebiam brancos. ${ }^{29}$ Isto é, a reinterpretação das coisas e dos

\footnotetext{
${ }^{27}$ MBEMBE, Achille. Crítica da razão negra. n-1 Edições, 2018, pp.41-3.

${ }^{28}$ FOUCAULT, Michel. As palavras e as coisas: uma arqueologia das ciências humanas. São Paulo, Martins, 2000.

${ }^{29}$ TODOROV, Tzvetan. Nós e os outros: a reflexão francesa sobre a diversidade humana. Rio de Janeiro: Jorge Zahar Ed., 1993.
} 
seres do mundo, por estar fundamentalmente atravessada pelo olhar do europeu, atualizaria, de muitas maneiras, a ideia de que o fenótipo e a moral branca eram universais. Nessa esteira, tudo o que lhe fosse alheio era reafirmado, agora pelo academicismo ilustrado, como bárbaro, exótico, inadequado.

A taxionomia de Lineu é considerada embrionária dessa perspectiva. De acordo com ela, o reino animal se subdividiria em seis grupos: quadrúpedes recorte no qual estariam inclusos os humanos-, aves, anfíbios, peixes, insetos e vermes. $\mathrm{O}$ esquema classificatório proposto por Lineu encarregava-se também de hierarquizar os seres vivos a partir de critérios definidos pela observação empírica. No universo de seres quadrúpedes, o homem seria, então, considerado o mais desenvolvido, ocupando posição superior a dos primatas nessa hierarquia. Não obstante, haveria ainda um outro nível classificatório, dedicado a organizar as diferenças entre os seres humanos, de modo a garantir o maior patamar de desenvolvimento ao tipo branco, abrindo brechas, inclusive, para que os negros fossem considerados mais próximos dos símios do que de seus semelhantes de pele clara.

A atualização da retórica de inferiorização dos não-brancos se deve, em grande medida, à universalização dessa lógica classificatória dos seres vivos e à sua aplicação sobre a questão da diversidade humana. O esquema classificatório proposto por Lineu reduziria todo o espectro de variações dos seres humanos a quatro tipos, baseados em dois aspectos: cor da pele e continente de origem. Ao atribuir características positivas aos classificados como brancos/europeus e negativas aos tipos americano/vermelho, asiático/escuro e africano/negro, ${ }^{30} \mathrm{com}$ algum efeito, Lineu reiterava toda aquela retórica da superioridade branca, que pelo menos desde o advento das Grandes Navegações vinha alinhavando uma série de estereótipos em prol de legitimar a dominação do ultramar.

A publicação de Systema Naturae (1735), obra na qual Lineu sistematizou essas suas concepções, adicionou uma outra camada às tantas que já compunham aquela retórica de hierarquização dos povos. A sua ambição classificatória

\footnotetext{
${ }^{30}$ A partir da leitura que Bethencourt realiza do Systema Naturae de Lineu, observa-se a adjetivação pejorativa como recurso utilizado pelo naturalista no sentido de estereotipar o outro a partir do seu lugar. Enquanto os europeus eram caracterizados como pálidos, sanguíneos e musculosos, os americanos eram acobreados, coléricos e eretos; os asiáticos, escuros, melancólicos e rígidos e os africanos, indolentes, negligentes e astuciosos. BETHENCOURT, Francisco. Racismos. São Paulo, Companhia das letras, 2018, p.345.
} 
contribuiria para revalidar essas noções, mas enunciando a questão por uma nova via: a de que a diversidade humana corresponderia à hierarquia da natureza. A reordenação discursiva gestada pelos novos saberes e pelas novas representações de mundo permitiriam, com algum efeito, que o ofício do viajante-naturalista orquestrasse justificativas que, amparadas pela razão, atestariam o caráter irrefutável, porque natural, da desigualdade entre os tipos humanos.

A recepção à obra de Lineu e a crítica daí decorrente incrementariam o debate entre os naturalistas europeus de então. Buffon (1707-1788) foi um dos que problematizou os esquemas classificatórios de Lineu. Para o naturalista francófono, as categorizações de Lineu não davam conta de enquadrar todos os povos do mundo, mesmo porque não consideravam as ondas migratórias e as consequentes miscigenações. Na esteira desse argumento, assinalava que dentro do universo do brancoleuropeu havia uma série de variações, assim como entre os identificados como negros/africanos. Ao refutar teorias sistematizadoras, que identificavam um continente a uma única cor, Buffon complexificava o debate sobre os fenótipos humanos, demonstrando a suscetibilidade dos povos às condições geográficas a que eram expostos. De acordo com suas observações, os deslocamentos e as miscigenações eram capazes de redefinir as características físicas e morais dos seres humanos e configurar uma infinidade de novos povos. Embora tenha contribuído para flexibilizar as noções estanques que reduziam os seres humanos a quatro tipos, Buffon reafirmava, em novos termos, a primazia dos europeus sobre os outros tipos humanos. Em diálogo com $O$ Espírito das Leis, ${ }^{31}$ publicado um ano antes por Montesquieu, Buffon afirmava, em sua Histoire Naturelle, que a perfeição dos brancos se devia ao clima ameno e à natureza temperada da Europa. Acrescentando, assim, uma outra camada de significado ao debate sobre a diferença humana, Buffon enunciava que o caráter físico e moral dos povos se moldava também pela interferência do meio e não apenas por condicionantes inatos à cada uma das raças. Se abria, no desdobrar dessas publicações de Montesquieu e Buffon, um filão de discussões que passariam a ponderar acerca da medida entre o quanto seria inato e o quanto seria mutável. Ou seja, o quanto das características humanas constituíam traços invariáveis e qual proporção dessas características poderiam ser consideradas modificáveis, se expostos a novos ambientes e a novos comportamentos.

${ }^{31}$ Charles-Louis de Secondat, barão de la Brède e de Montesquieu viveu entre 1689 e 1755. Do espirito das Leis, publicado em 1748. 
No caminho pavimentado por Buffon, outros tantos nomes se arriscariam a pensar o gênero humano e os porquês de suas variações. O anatomista e antropólogo Johann Friedrich Blumenbach (1752-1840) seria um deles. ${ }^{32}$ Embora tenha formulado sua tese a partir de critérios classificatórios, foi um dos mais contundentes críticos da teoria de Lineu, contribuindo para o debate acerca da possibilidade de aperfeiçoamento dos povos considerados inferiores. Em diálogo com as teorias correntes de medição dos corpos, J.F. Blumenbach defendia que as distinções entre as raças deveriam ser averiguadas a partir do tamanho do crânio, do posicionamento das mandíbulas e do alinhamento das orelhas. Orientado por esse método, reiterava a longa tradição retórica de superioridade racial dos que chamava caucasianos, chancelando-os como raça primeva, enquanto as demais seriam raças degeneradas. Mas, tal condição degenerativa não era vista por Blumenbach como algo estritamente relacionado aos condicionantes raciais, mas sim determinado pelo ambiente, mais especificamente pelas circunstâncias climáticas e pelo relevo, tal como já haviam sugerido Montesquieu e Buffon. Fato é que Blumenbach se converteria em um dos maiores defensores da monogenia, contrapondo autores, a ele contemporâneos, pautados pelas noções de que as variações humanas correspondiam a raças originadas por diferentes processos formativos. ${ }^{33}$ Articulando método anatômico à observação da interação entre sujeito e ambiente, sua obra contribuiria para fundamentar, mediante a autoridade da qual era/ é investido o discurso médico, o entendimento de que os africanos eram humanos. Essas suas alegações ajudariam a superar a sugestão de Lineu de que haveria afinidades físicas entre os negros/ africanos e os primatas e de que o negro ocuparia, em função de suas supostas características animalescas, o último nível da escala de humanidade na classificação proposta pelo Systema Naturae.

Importa, sobretudo, pensar que Blumenbach seria mais um dos autores a fazer coro ao entendimento de que os brancos/europeus poderiam investir no melhoramento das ditas raças degeneradas, já que essa seria uma condição desencadeada pela exposição desses povos a ambientes desfavoráveis ao seu

\footnotetext{
${ }^{32}$ BETHENCOURT, Francisco. Racismos. São Paulo, Companhia das letras, 2018, p.33.

${ }^{33}$ Estes que defendiam as distintas origens dos povos eram os chamados Poligenistas, enquanto os Monogenistas eram aqueles que defendiam uma origem comum a todos os seres humanos, embora não deixassem de hierarquizá-los. Segundo Francisco Bethencourt, Voltaire teria sido um dos mais influentes poligenistas, "ajudando a naturalizar as variedades dos seres humanos, atribuindo diferentes tipologias humanas às diferentes criações." Ver: BETHENCOURT, Francisco., op.cit., p.350.
} 
próprio desenvolvimento. Fossem esses ambientes associados à ideia de escassez, como era comumente retratada a África, ou à ideia de abundância, tal qual era relatada a natureza da América, o discurso europeu sobre a diferença sempre encontraria modos de justificar a indisposição de suas alteridades para o desenvolvimento, tal qual sua própria experiência havia definido como padrão a ser alcançado. Então, quando Blumenbach defendia a propensão dos negros ao aperfeiçoamento, ele defendia, em uma dimensão talvez menos óbvia, que a parte do caráter do negro comprometida pelos fatores externos constituía a parcela recuperável, enquanto aquilo que lhes era inato, porque inerente à sua raça, permaneceria na ordem do irreparável.

A esse tempo, caía em desuso a ideia de degeneração das raças supostamente inferiores e ia se credenciando a ideia de reversibilidade da condição de barbárie. Isto é, a noção de que negros, índios, malaios e tantos outros poderiam ser aperfeiçoados nos modos, nos costumes e na espiritualidade ia forjando as bases daquilo viria a se configurar como a retórica civilizatória nas primeiras décadas do XIX. Aliás, o sentido de melhoramento racial cunhado pelo racionalismo ilustrado correspondia ao espraiamento que a ideia de progresso vinha adquirindo em meio ao fluxo de novos saberes que faziam parecer insuficientes os cabedais dos quais dispunham e que, por isso, impunham uma incessante necessidade de superação. Assim, a retórica da superioridade física e moral europeia corroborava e era, ao mesmo tempo, corroborada pela compreensão de um tempo linear, um tempo de avanços, um tempo no qual o devir do progresso soava como um devir universal. A longa tradição retórica de hierarquização dos povos, atualizada pelos naturalistas, passaria a se inclinar, então, ao entendimento de que era preciso melhorar os que eles acreditavam ser, para além de racialmente inferiores, também atrasados em termos civilizacionais.

Os primeiros escritos de José Bonifácio dedicados a descrever a condição dos índios e dos negros no Brasil datam de 1813, mesmo ano, aliás, em que Prichard (1786-1848) desdobrava o debate sobre a origem da diferença, publicando a primeira edição de Researches into the Physical History of Mankind. ${ }^{34}$ A obra de Prichard ecoava influências de Buffon e Blumenbach, sobretudo no que tangia ao discurso em prol do aperfeiçoamento dos não-brancos, endossando, portanto, a

\footnotetext{
${ }^{34}$ James Cowles Prichard. Researches into the Physical History of Mankind. $1^{\mathrm{a}}$ ed., 1813.
} 
noção de que um conjunto de variáveis circunstanciais contribuía para determinar o caráter de um povo. Ecos presentes também nos escritos do José Bonifácio de 1813, um filósofo e naturalista, nascido em Santos, formado na tradição coimbrã e frequentador de algumas das mais relevantes academias de ciências naturais europeias. 35

Em carta redigida nesse mesmo ano, o então Secretário da Academia Real de Ciências de Lisboa, enunciava uma preocupação bastante característica dos que integravam o circuito de naturalistas europeus. Bonifácio diria, nessa ocasião, a frase considerada emblemática de suas inquietações em relação à sua pátria de origem, um Brasil que, então, sediava a Corte e vinha se convertendo na porção mais promissora do Império ultramarino português. ${ }^{36}$ A emblemática colocação, formulada a partir de metáforas mineralógicas, diagnosticava que "muito difícil ser[ia] a liga de tanto metal heterogêneo, como brancos, mulatos, pretos livres e escravos, índios e etc em um corpo sólido e político." ${ }^{37}$ Impressão que demonstrava o desconforto de Bonifácio com as alteridades definidas por oposição ao branco/português/colonizador. Desconforto que nesse trecho, à propósito, já manifesta a racialização de seu discurso na medida em que aponta a diferença fenotípica - e a diferença jurídica a ela correspondente - como problemática a ser enfrentada pelos que se definiam como os dirigentes da Corte. Ao Bonifácio que havia convivido com figuras como Sage, Jussier e Lavoisier na Escola de Minas de Paris e, com Alexander von Humboldt, na Escola de Freiberg ${ }^{38}$ a questão da coexistência entre o que considerava serem raças distintas não apenas fisicamente, como moralmente, lhe sugeriam que o maior desafio com o qual as elites do Brasil

\footnotetext{
${ }^{35}$ Além de sócio da Academia Real das Ciências de Lisboa, José Bonifácio foi sócio da Sociedade Filomática e de História Natural de Paris, foi membro da Sociedade Mineralógica de Iena, bem como da Academia de Ciências de Estocolmo, da Sociedade Geológica de Londres, da Sociedade Werneriana de Edimburgo, além de membro correspondente do Instituto de França. A esse respeito, ver: SOUSA, Otávio Tarquínio de. José Bonifácio. Coleção Documentos Brasileiros. Livraria José Olympio Editora: RJ, 1972.

${ }^{36}$ ARAUJO, Valdei Lopes de. A experiência do tempo: conceitos e narrativas na formação nacional brasileira (1813-1845). São Paulo: Editora HUCITEC.

${ }^{37}$ Carta escrita por José Bonifácio de Andrada e Silva a Domingo Antônio de Sousa Coutinho Conde de Funchal -, em julho de 1813. Ver: Projetos para o Brasil / José Bonifácio de Andrada e Silva: organização Miriam Dolhnikoff. São Paulo: Companhia das letras; Publifolha, 2000, p.88.

${ }^{38}$ Alexander von Humboldt havia sido discípulo de Blumenbach e havia recuperado uma série de argumentos defendidos em Buffon, em Herder e em Prichard. José Bonifácio, por sua vez, foi contemporâneo de Alexandre von Humboldt em Freiberg, onde estudaram juntos entre 1792 e 1794, sob orientação do geólogo Abraham Gottlob Werner. A esse respeito, ver: BETHENCOURT, Francisco. Racismos: das Cruzadas ao século XX. São Paulo: Companhia das Letras, 2018, p.367. E ver também: SOUSA, Otávio Tarquínio de. José Bonifácio. Coleção Documentos Brasileiros. Livraria José Olympio Editora, Rio de Janeiro, 1972, p. 26-7.
} 
de D. João VI se deparariam seria "vencer as dificuldades que se op[unham], por causa das raças e escravidão.” ${ }^{39}$ Para Bonifácio, assim como para Blumenbach, a escravidão significava um equívoco, à medida em que contribuiria para corromper o caráter dos escravizados e para viciar os proprietários em relações promíscuas de prestação de serviços. A impressão de Bonifácio era a de que “(...) os escravos, entes vis e corrompidos, afogam nos meus patrícios os sentimentos nobres e liberais desde o berço, cercando-os desde a infância de uma atmosfera pestilenta." ${ }^{40}$ Há, portanto, nas ideias de Bonifácio, uma significativa interlocução com o debate em curso sobre a questão das diferenças humanas. Uma interlocução que, para além de o persuadir a respeito dos danos causados pelo escravismo, lhe fariam advogar, tal qual vinham sugerindo Buffon, Blumenbach e Prichard, em defesa da noção de aperfeiçoamento dos que eram vistos pela branquitude ilustrada como inferiores.

As observações feitas em 1813 dão a ver o embrião de algumas das pautas que viriam a ser mais exploradas em um outro contexto, o da Assembleia Constituinte de 1823. Ocasião em que Bonifácio apresenta duas peças legislativas, sendo uma sobre o que entendia ser a necessidade de civilizar os índios e outra sobre os efeitos corrosivos da escravatura de negros para o imperativo civilizatório. Como a exegese desses dois textos caberá ao último item deste capítulo, aqui problematizaremos, por mais algumas linhas, as inquietações colocadas por um Bonifácio ainda radicado em Lisboa, em relação a um Brasil onde desejava ansiosamente servir. ${ }^{41}$

Cabe retomar a carta escrita ao Conde de Funchal em 1813. Nela, Bonifácio avisava a seu destinatário que, quando chegasse ao Brasil, deveria se precaver em relação aos cafres e cimérios $^{42}$ com os quais se deparasse, alertando-o, como que em uma espécie de inversão da retórica do aperfeiçoamento, que cuidasse para que não se deixasse degenerar pela convivência com índios e negros. O alerta, nas suas palavras, era de que "ser[i]a difícil amalgamar-se com os outros semimebais [sic]

\footnotetext{
${ }^{39}$ José Bonifácio de Andrada e Silva. A povoação do Brasil. Projetos para o Brasil / José Bonifácio de Andrada e Silva: organização Miriam Dolhnikoff. São Paulo: Companhia das Letras; Publifolha, 2000 p.97-8.

40 José Bonifácio de Andrada e Silva. Os índios são muito imaginativos. Organização Miriam Dolhnikoff. São Paulo: Companhia das letras; Publifolha, 2000, p.72.

${ }^{41}$ Ibid., p.88.

${ }^{42}$ Alusão ao sentido pejorativo do termo cafre, tal como era utilizado pelos ibéricos para designar os negros de África. E o uso do termo cimério parece ser uma alusão à ideia de barbárie associada aos povos homônimos do Cáucaso. Carta escrita por José Bonifácio de Andrada e Silva a Domingo Antônio de Sousa Coutinho - Conde de Funchal -, em julho de 1813. Ver: José Bonifácio de Andrada e Silva., op.cit., p.87.
} 
[e que] não permit[isse] o céu que neste amálgama [ele] se neutraliz[asse] de todo, porque então esta[ría]mos perdidos." ${ }^{43}$ Nesse trecho, Bonifácio deixa entrever um juízo já polêmico para a época a respeito do que se ventilava como justificativa para o que supunham constituir a condição degenerativa dos povos da América. Esse tipo de alegação guardava relação com noções de que os povos da América possuíam compleição e inteligência humana inferiores e que tais características teriam sido moldadas pelo clima e pelo o que a natureza os oferecia. Não por acaso, esse havia sido o mote de um amplo debate protagonizado por Cornelius de Pauw, Abade Raynal e Buffon. ${ }^{44}$ A contenda parece ter se configurado como desdobramento à primeira edição da Histoire Naturelle de Buffon, quando o etnólogo Cornelius de Pauw teria ajuizado sobre a indolência inerente aos povos americanos, vinculando a sua suposta aversão ao trabalho à natureza que os cercava. Isto é, a partir do que Buffon havia afirmado acerca da "mediocridade da natureza americana, então retratada como habitada por animais, plantas e seres humanos inferiores, $" 45$ Cornelius de Pauw e Abade Raynal concluiriam em favor da ideia de que havia um traço degenerativo no caráter dos povos americanos, traço esse definido por fatores externos, ou seja por circunstancias que extrapolavam aquilo que acreditavam ser condicionantes raciais. Embora Buffon tenha feito um adendo à segunda edição de sua obra - publicada em 1777, ponderando as asserções de sua primeira edição que teriam encorajado as afirmações de De Pauw e Raynal, as interpretações a sua obra acabaram contribuindo para difundir entre os círculos letrados ilustrados a noção de que a abundância da natureza americana determinava um comportamento que, aos olhos da razão europeia, evocava a ideia de resignação e estagnação dos que nomeavam índios. ${ }^{46}$ Não nos parece casual, portanto, o conselho dado por Bonifácio ao Conde de Funchal. Seu alerta guarda, nas entrelinhas, uma aproximação com a disseminada visão de De Pauw de que os

\footnotetext{
${ }^{43}$ Carta escrita por José Bonifácio de Andrada e Silva a Domingo Antônio de Sousa Coutinho Conde de Funchal -, em julho de 1813. Ver: Projetos para o Brasil / José Bonifácio de Andrada e Silva: organização Miriam Dolhnikoff. São Paulo: Companhia das letras; Publifolha, 2000, p.88.

${ }^{44}$ De acordo com Otávio Tarquínio de Sousa, Buffon era uma das principais referências intelectuais de Bonifácio. Ver: SOUSA, Otávio Tarquínio de. José Bonifácio. Coleção Documentos Brasileiros. Livraria José Olympio Editora, Rio de Janeiro, 1972, p.30.

${ }^{45}$ BETHENCOURT, Francisco. Racismos: das Cruzadas ao século XX. São Paulo: Companhia das Letras, 2018, p.348.

${ }^{46}$ LINDO, Luiz Antônio. A América dividida entre Cornelius de Pauw e Gabriel Soares de Sousa. Cadernos PROLAM / USP (Ano 11 - vol.2 - 2012, p.35-44), p.38-9.
} 
próprios europeus, quando expostos, por longo período, aos habitantes do Novo Mundo, correriam o risco de se degenerar." ${ }^{47}$

A escrita do Bonifácio naturalista, envolvido com a Restauração portuguesa, acerca do cenário da Corte e dos domínios a ela contíguos, antecipa, através do que diagnostica, o imbróglio no qual a branquitude civilizada luso-americana se veria envolvida nessas primeiras décadas do XIX: equacionar as diferenças que ela mesma havia produzido, uma vez que passaria a lhes soar cada vez mais indispensável a singularização dos povos, das pátrias e das nações, como veremos adiante.

\subsection{Dos povos e das pátrias do Brasil}

Ao decidir transferir-se para o que chamou de novo Portugal, José Bonifácio de Andrada e Silva declarava-se pesaroso em deixar para trás, e em definitivo, os seus afazeres literários na Academia Real das Ciências de Lisboa, ${ }^{48}$ todavia parecia otimista em relação a sua pátria de nascimento, uma vez que demonstrava-se inspirado um horizonte de possibilidades animadoras, sobretudo, se comparadas as do antigo Portugal. ${ }^{49} \mathrm{O}$ cenário do anúncio da partida de Bonifácio de Lisboa era o da disputa entre os que defendiam o retorno da família Real, então considerada condição primária à restauração da Monarquia após a derrota das forças napoleônicas, e os que se afinavam à noção de que a grande nação portuguesa poderia se regenerar mesmo que a sua sede permanecesse na inculta América. ${ }^{50}$

Começava ali a ganhar consistência uma noção de regeneração, onde o Brasil, considerado parte equânime da nação portuguesa, disporia de espaço suficiente para desenvolver suas potencialidades, sem que fosse cerceado por qualquer espécie de argumento capaz de evocar pretensões recolonizadoras. ${ }^{51}$

\footnotetext{
${ }^{47}$ LINDO, Luiz Antônio. A América dividida entre Cornelius de Pauw e Gabriel Soares de Sousa. Cadernos PROLAM / USP (Ano 11 - vol.2 - 2012, p.35-44), p.38-9.

48 José Bonifácio desempenhou a função de Secretário da Academia Real das Ciências de Lisboa entre os anos de 1813 e 1819, quando anunciou que retornaria ao Brasil. ver: José Bonifácio de Andrada e Silva. Discurso Histórico recitado na sessão pública de 24 de junho de 1819. Disponível em www.obrabonifacio.com.br.

49 Sobre o Antigo e o Novo Portugal, ver: José Bonifácio de Andrada e Silva. Discurso Histórico recitado na sessão pública de 24 de junho de 1819. Disponível em www.obrabonifacio.com.br, p.1.

${ }^{50}$ Ibid., p.28.

${ }^{51}$ Ibid., idem.
} 
Regenerar se assemelharia, portanto, a revitalizar, a arejar as dependências entranhadas pelos odores do Antigo Regime, ${ }^{52}$ garantindo, não obstante, que os "laços indissolúveis prend[essem] as diferentes partes da Monarquia em ambos os hemisférios." ${ }^{53}$ Ainda que confiante no potencial da Monarquia Brasílica, ${ }^{54}$ Bonifácio demonstrava preocupação não só em relação aos efeitos do escravismo, como também em relação ao quantitativo de habitantes alheios ao que entendiam como os parâmetros civilizatórios. Sua expectativa parecia ser, então, a de um missionário laico, incumbido da tarefa de criar estratégias que convertessem os contingentes humanos que julgava viver em barbárie, em sujeitos que lhe fossem próximos no aspecto comportamental, mas que, ao mesmo tempo, se mantivessem em condição subalterna. Para tanto, considerando universais os saberes com os quais havia interagido em suas incursões por Paris, Freiberg, Estocolmo e Copenhagen, propunha que a transformação do que chamava inculto se realizasse através da conversão aos saberes canonizados pelo racionalismo ilustrado, bem como pela inculcação dos parâmetros do cristianismo. ${ }^{55}$ Assim, a edificação de $u m$ grande e vasto Império português, com sede no Brasil, estaria condicionada ao sucesso da operação de adequação dos povos ao que a branquitude/ europeia/ civilizada definia como polidez, na chave do que consideravam bons costumes.

Aqui fica evidente a relevância dos imperativos civilizacionais para o projeto regenerador da Monarquia portuguesa afiançado por Bonifácio. Isto é, para que o novo Portugal adentrasse o rol dos civilizados e sediasse a recuperação do mundo lusitano, lhe parecia imprescindível que a barbárie na qual julgava se

\footnotetext{
${ }^{52}$ A respeito do conceito de regeneração, ver: NEVES, Lúcia Maria Bastos Pereira das. Corcundas e constitucionais: a cultura política da Independência (1820-1822). RJ: Revan: FAPERJ, 2003, pp.169-72.

53 José Bonifácio de Andrada e Silva. Lembranças e Apontamentos do Governo provisório da província de São Paulo para os seus Deputados. Disponível em www.obrabonifacio.com.br, p.95.

${ }^{54}$ Cabe aqui salientar que o uso da expressão Monarquia Brasílica, por José Bonifácio, em seu Discurso de despedida da Academia Real de Ciências de Lisboa, em 24/06/1819, faz referência à fundação de uma Monarquia brasílica como sede alternativa à peninsular. Ou seja, não há aqui menção a uma Monarquia independente, mas sim a uma parte brasílica da Monarquia portuguesa. Ver: José Bonifácio de Andrada e Silva. Discurso Histórico recitado na sessão pública de 24 de junho de 1819. Disponível em www.obrabonifacio.com.br, p. 29.

${ }^{55}$ Bacharel em Direito e Filosofia por Coimbra, José Bonifácio recebeu financiamento Real para desenvolver estudos mineralógicos em algumas das Escolas de maior repercussão da Europa, frequentando, assim, as aulas de Mineralogia em Paris e em Freiberg, por onde se formou em 1794. Depois de formado, Bonifácio realizaria viagens de estudos por Áustria, Prússia e península itálica. Entre 1796 e 1799 fixou residência na Suécia, onde aprofundou seus estudos. Em seguida, mudouse para a Dinamarca, lá permanecendo até retornar a Portugal, em 1800. A esse respeito, ver: Projetos para o Brasil / José Bonifácio de Andrada e Silva: organização Miriam Dolhnikoff. São Paulo: Companhia das letras; Publifolha, 2000, pp.15-17.
} 
encontrar grande parte dos habitantes não-brancos fosse revertida pelos valores civilizacionais cunhados pela branquitude europeia. Nessa esteira, o Brasil seria crescentemente mobilizado pelo universo letrado lusófono - tanto por portugueses europeus quanto por portugueses americanos - como via para a redenção portuguesa. No lastro da Revolução Liberal de 1820, os letrados de ambas as porções do mundo português, a peninsular e a americana, vislumbravam, no limite, a possibilidade de um recomeço. Esses sujeitos, imbuídos das convicções que os definiam como representantes de uma raça e de uma moral superiores, operariam, pelo menos até 1821 , com a noção do novo regulado pela continuidade. Em outras palavras, apostariam em uma nova relação entre a porção americana e a peninsular do Reino Unido, na intenção de redefinir o pertencimento de um ao outro, evitando que alguma possibilidade de emancipação ganhasse fôlego.

Em meio aos debates constitucionais nas Cortes de Lisboa e às disputas em torno da permanência da família real no Rio de Janeiro, foi crescente a efervescência do debate político, mesmo quando ainda existia a censura às tipografias da porção americana do Reino. Com o fim das interdições, em agosto de 1821, as articulações políticas e o debate crítico aconteciam através de correspondências e de impressos clandestinos que se disseminavam oralmente. ${ }^{56}$ Os panfletos e as cartas produzidos nos primeiros meses de 1821 no Rio de Janeiro demonstram que a ideia de pertencimento do Brasil à nação portuguesa permanecia intocável. Em uma das muitas cartas trocadas entre os letrados lusófonos imersos nessas questões, o autor de codinome Portuense Imparcial escreveria ao então livreiro Evaristo da Veiga ${ }^{57}$ reafirmando "a união dos dois Hemisférios Portugueses, [de modo que] forma[ssem] ambos um poderoso Império, sob um Governo liberal e justo." 58

Diante da acolhida de D. João às reivindicações peninsulares e do seu retorno ao antigo Portugal, essas falas em prol de uma união fraterna entre portugueses brasileiros e portugueses europeus ecoariam enunciando outras possibilidades de se pensar a relação entre as diferentes partes do Reino Unido. José

\footnotetext{
56 NEVES, Lúcia Maria Bastos Pereira das. Corcundas e constitucionais: a cultura política da Independência (1820-1822). RJ: Revan: FAPERJ, 2003.

${ }^{57}$ A comum tática do uso de pseudônimos também seria mobilizada por Evaristo da Veiga, que se autodenominava Estudante Constitucional. Ver: CARVALHO, José Murilo de; BASTOS, Lucia; BASILE, Marcelo. Guerra literária: panfletos da independência (1820-1823). Vol.1:Cartas. Belo Horizonte: Editora UFMG, 2014. p. 260.

${ }^{58}$ Ibid., p. 260.
} 
Bonifácio, já de volta ao Brasil há dois anos e, nessa ocasião ocupando o posto de vice-presidente da Junta Provisória da província de São Paulo, apontaria algumas alternativas capazes de solucionar o impasse em torno da definição de onde deveria se estabelecer a sede da Monarquia,

se no Reino do Brasil (...) ou alternativamente pelas séries dos Reinados em Portugal e no Brasil, ou finalmente no mesmo reinado por certo tempo que se determinar, para que assim possa o Rei mais depressa e por turno satisfazer reciprocamente as saudades de seus Povos. ${ }^{59}$

O posicionamento de Bonifácio em relação à preservação do protagonismo do Brasil dentro do mundo português fica aqui evidente, dando a entender que aceitariam, no máximo, o revezamento da sede da monarquia. Ou seja, a opção de perder em definitivo a condição de capital do Reino Unido não figurava no horizonte de alternativas do grupo de Bonifácio. Portanto, a manutenção da unidade entre as partes brasílica e portuguesa do Reino estariam condicionadas à salvaguarda da capitalidade do Rio de Janeiro. Para tanto, propunham a instituição de um Governo Geral Executivo - com sede no Rio-, ao qual as demais províncias deveriam estar subordinadas. De acordo com o grupo de Bonifácio, nas ocasiões em que o Rei estivesse a governar o Reino Unido a partir da península, o Governo Executivo do Brasil ficaria a cargo do Príncipe herdeiro, já expressando um indício da aproximação entre D. Pedro e esse grupo.

Ocorre que algumas das mais expressivas províncias desse mosaico luso americano não compactuavam com a liderança exercida nomes de São Paulo e do Rio de Janeiro. De acordo com o Correio Brasiliense de Hipólito José da Costa, ${ }^{60}$ o episódio da transferência da Corte para o Rio de Janeiro - e a posterior elevação da cidade à sede do Reino Unido - teria dado origem a um gradativo desequilíbrio entre as províncias americanas lusófonas, pois o Rio de Janeiro, privilegiado nessa dinâmica, teria despertado "o ciúme de umas províncias a respeito das outras."61 Aliás, se nesses escritos eram recorrentes as vezes em que os autores se autorreferenciavam como brasileiros portugueses, em outras expressivas

\footnotetext{
59 José Bonifácio de Andrada e Silva. Lembranças e Apontamentos do Governo provisório da província de São Paulo para os seus Deputados (10/10/1821). Disponível em www.obrabonifacio.com.br, p.96.

${ }^{60}$ Hipólito havia sido contemporâneo de Jose Bonifácio em Coimbra. Radicado em Londres, editava e dirigia o periódico Correio Brasiliense, discutindo temas que em sua terra natal eram interditados ao público pela censura.

${ }^{61}$ Apud Sérgio Goes de Paula (org.). Hipólito José da Costa. São Paulo: Editora 34, p.221.
} 
províncias, seus habitantes reconheciam-se menos como brasileiros e mais como baienses ou paraenses portugueses. ${ }^{62}$ Isto é, para além de suas pátrias locais, ${ }^{63}$ a referência de pertencimento de um súdito lusoamericano era a nação portuguesa, o que ajuda a compreender, a despeito da filiação ao Rio de Janeiro, a adesão massiva das demais províncias americanas do Império ao constitucionalismo peninsular. ${ }^{64}$

Interessante notar como a distinção regional entre essas plurais identidades se acentuaria ainda mais a partir das medidas impostas pela Câmara Constitucional lisboeta no sentido de fazer recuar a autonomia da porção americana do Reino Unido. ${ }^{65}$ Tais decisões seriam alvo de volumosa repercussão nos impressos da porção americana do Reino, sobretudo no mês de dezembro de 1821, ocasião em que as notícias sobre os decretos de Lisboa chegaram ao conhecimento dos letrados desse lado do Atlântico. Joaquim Gonçalves Ledo e Januário da Cunha Barbosa, redatores do Revérbero Constitucional Fluminense, em circulação há poucos meses,${ }^{66}$ incentivavam a anuência das demais províncias à causa do Rio de Janeiro, pois, na percepção desses liberais brasilienses o cenário de desunião comprometeria o crescimento forte e saudável do Reino do Brasil. ${ }^{67}$ Em edição de

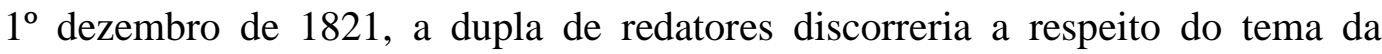
conciliação entre as províncias e sugeriria caminhos para que a unidade do Reino Unido ficasse imune aos turbulentos tempos. Ao grupo de Ledo e Januário, aquela ideia de regeneração política portuguesa, tendo como epicentro a porção americana dos domínios da Coroa, ainda parecia fazer sentido, embora já considerassem inadmissível qualquer tipo de subordinação às autoridades peninsulares, nas suas palavras:

\footnotetext{
62 JANCSO, Istvan \& PIMENTA, João Paulo. Peças de um mosaico ou apontamentos para o estudo da emergência da identidade nacional brasileira. In: MOTA, Carlos Guilherme (org.). Viagem incompleta: a experiência brasileira (1500-2000). São Paulo: Senac, 2000.

${ }^{63}$ A respeito das mutações semânticas do conceito de pátria, ver: PAMPLONA, Marco A. Pátria Brasil. In: SEBÁSTIAN, Javier Fernandez (Dir.). Dicionario Politico y social del mundo iberoamericano. Tomo 8, Centro de Estudos Politicos y Constitucionales: Madrid, 2014.

${ }^{64}$ JANCSÓ, Istvan. Independência, independências. In: JANCSÓ, Istvan (org.) Independência: História e Historiografia. São Paulo: Hucitec: Fapesp, 2005. p. 21.

${ }^{65}$ Tais medidas foram assinadas pelas Cortes em 29/09/1821. A esse respeito, ver: CARVALHO, José Murilo de; BASTOS, Lucia; BASILE, Marcelo. Constitucionalismo, liberalismo, nação. In: CARVALHO, José Murilo de; BASTOS, Lucia; BASILE, Marcelo (orgs.). Guerra literária: panfletos da independência (1820-1823). Vol.2: Análises. Belo Horizonte: Editora UFMG, 2014. p.16-9.

${ }^{66}$ A primeira edição do Revérbero data de 15 de setembro de 1821 . Em dezembro, mês em que o debate sobre o caráter recolonizador das determinações das Cortes ganha vulto, os jornais impressos no Rio de Janeiro tinham pouco tempo de atividade regular, já que até agosto deste mesmo ano vigorava a proibição às impressões independentes.

${ }^{67}$ Revérbero Constitucional Fluminense, no VI, Rio de Janeiro, 1821.
} 
(...)este Continente não pode jamais estar em uma dependência absoluta do outro Continente, e a grandeza da Nação exige, para conservar-se e crescer, que, ou a sede do governo seja no Brasil, (...) ou que o Brasil tenha um governo central seu subordinado e sancionado por aquele, e apertado com todos os laços do Comércio, uniformidade de Rito e de Língua, e com todas as prisões de parentesco. ${ }^{68}$

Assim, o Revérbero evidenciava a sua intolerância em relação aos decretos das Cortes, principalmente no que se referia à exigência de que D. Pedro abandonasse a regência no Rio de Janeiro e retornasse à matriz do Império. Diante das circunstâncias, o jornal demarcava bem o pertencimento do Brasil à grande nação portuguesa, mas já adiantava que nenhum passo atrás seria admitido no que concernia à centralidade do Rio de Janeiro. Aliás, as especulações em torno do caráter recolonizador das determinações das Cortes de Lisboa pautariam, em ambos os lados do Atlântico, uma reordenação do discurso. ${ }^{69}$ Se até então havia apoio das províncias americanas ao constitucionalismo peninsular, porque ele inspirava um grande pacto entre as distintas partes da nação portuguesa, agora se disseminava uma sensação de desconfiança em relação às intenções dos Deputados lisboetas. $\mathrm{Na}$ percepção de Bonifácio, eles "pretend[iam] desunir, enfraquecer e até deixar em mísera orfandade (...) a grande família Brasileira (...)", ${ }^{70}$ o que configuraria, no seu entender, um significativo golpe na capitalidade do Rio de Janeiro. Além disso, Bonifácio alertava que, numa perspectiva territorial mais ampla, tais medidas concorreriam para refundar as relações burocráticas, submetendo as províncias americanas do Reino Unido à Lisboa, e não mais ao Rio de Janeiro. No entanto, para as províncias do norte - entre elas Bahia, Pará e Maranhão -, há muito preteridas pela centralidade adquirida pelos fluminenses, os Decretos de Lisboa não incomodavam tanto quanto aos grupos afinados às demandas da Corte, pois para as províncias da porção norte da América portuguesa estarem submetidas ao Rio de Janeiro ou à Lisboa incorria em similar distanciamento e em análogas privações. Em função disso, nessa querela entre os Deputados da Constituinte lisboeta e o Governo Executivo sediado no Rio de Janeiro, baienses, paraenses, sergipanos e

\footnotetext{
${ }^{68}$ Revérbero Constitucional Fluminense, ${ }^{\circ}$ VI, Rio de Janeiro, 1821., p. 76.

69 Convém sublinhar que, embora as Cortes nunca tenham determinado explicitamente a recolonização do Brasil, a recepção desses decretos teceria argumentações que, numa crescente, associariam as polêmicas medidas a um enunciado discursivo potencialmente inflamador. CARVALHO, José Murilo de; BASTOS, Lucia; BASILE, Marcelo. Constitucionalismo, liberalismo, nação. In: CARVALHO, José Murilo de; BASTOS, Lucia; BASILE, Marcelo (orgs.). Guerra literária: panfletos da independência (1820-1823). Vol.2: Análises. Belo Horizonte: Editora UFMG, 2014. p.18.

${ }^{70}$ Ibid., idem.
} 
maranhenses se posicionariam, coerentemente, ao lado de Lisboa, o que esgarçaria ainda mais a frágil unidade do reino americano. Diante do risco iminente de fragmentação do reino do Brasil, o mesmo Portuguez Europeo, João Gualberto Pereira, advertia:

\begin{abstract}
Brasileiros dai as mãos, e segui todos uma só voz. Em um só partido e seja este o de reconhecerdes o herdeiro do Trono Português, por Augusto regente do Brasil, proclamai nele a total Regência do vosso Continente e estabelecei-lhe aquele Governo, que melhor vos convier para ele o fazer executar, pois que sendo como sois um só povo livre, ninguém com justiça poderá disputar-vos esse direito.(...) Brasileiros, outra vez vos suplico por vós mesmos, que aproveiteis o momento de serem um Povo Grande, temido e respeitado, e o mais bem-aventurado de toda a terra. ${ }^{71}$ (grifos meus)
\end{abstract}

Os Deputados de Lisboa, ao tentarem recobrar o controle administrativo do Brasil e frustrar a sua autonomia política, não poderiam imaginar as tensões que despertariam. O trecho acima destacado é expressão disso. $\mathrm{O}$ folheto conclamava os povos brasileiros a se unirem contra os desmandos das Cortes e aproveitarem a oportunidade de se tornarem um só Povo. Portanto, ao reconhecer na pluralidade das identidades americanas um entrave à constituição de uma oposição consistente à Lisboa, o autor destaca aquele momento como oportuno para que os então povos brasileiros superassem as suas diferenças, configurassem um só Povo e aderissem, fortalecidos por essa subjetividade, a um projeto unitário de país. Ao suplicar aos brasileiros que constituíssem um povo grande, o autor sugere uma semântica antagônica a um termo até então usado para designar a diferença. Sua fala exprime a força impressa pelas circunstâncias ao contexto linguístico: seria mais conveniente o termo povo se singularizar e passar a corresponder ao território que se forjava como unidade política, do que continuar a representar os povos em suas idiossincrasias, reiterando as incompatibilidades regionais.

Todavia, dia a dia tomavam vulto especulações a respeito do posicionamento de D. Pedro no imbróglio entre os grupos do Rio de Janeiro, as províncias do Norte e os Deputados das Cortes de Lisboa. Cresciam as inquietações porque o momento se configurava como decisivo para a construção de um horizonte aberto a possibilidades até então desconhecidas. Se na Representação apresentada por Bonifácio em 24 de dezembro, ele já havia deixado claro que "os Brasileiros, e

\footnotetext{
${ }^{71} \mathrm{O}$ folheto em questão intitula-se: "Incontestáveis reflexões, que hum Portuguez Europeo oferece aos sentimentais Brasileiros sobre os seus interesses a face do presente”. In: CARVALHO, José Murilo de; BASTOS, Lucia; BASILE, Marcelo (orgs.). Guerra literária: panfletos da independência (1820-1823). Vol.2: Análises. Belo Horizonte: Editora UFMG, 2014. p. 508-9.
} 
mormente os Paulistas, estavam todos prontos a verter a última gota do seu sangue e a sacrificar todos os seus haveres para não perderem o Príncipe idolatrado", ${ }^{72}$ uma semana adiante, o mesmo Bonifácio já reformularia seu argumento no sentido de exortar a uma possível independência do Brasil, indagando se:

(...) era possível, pois, (...) que os brasileiros de hoje, herdeiros dos nobres sentimentos, e valor de seus antepassados, e ilustrados pelas luzes do século, não vivessem possuídos do amor da glória, e cada vez mais inflamados no desejo de ver livre, e independente o seu país natal[?] ${ }^{73}$ (grifos meus)

Com esse enunciado, Bonifácio rescindia grande parte daquele pacto regenerador que o havia motivado a retornar ao Brasil e chancelava as possibilidades de independência que viessem a surgir naquele contexto de manifestações recepcionadas como despóticas. Em sua interpretação, os princípios ilustrados e os nobres sentimentos estavam sendo aviltados por um arcaísmo político inaceitável, o que justificaria uma radicalização no sentido de uma emancipação controlada. A menção que faz no trecho acima ao valor dos antepassados, em breve deixaria de constituir uma referência e passaria a ser associado a um passado português maculado pela tirania e pela espoliação. ${ }^{74}$

De qualquer modo, estavam lançadas as alternativas com as quais D. Pedro dialogaria por alguns dias até optar pelo rompimento com as Cortes e pela preservação do Brasil sob seu controle. Abria-se aqui uma outra perspectiva aos súditos americanos da nação portuguesa, agora conclamados a reunirem-se sob um governo central e alheio às determinações dos constitucionais da península. Com a negativa de D. Pedro em retornar a Portugal, a causa dos grupos articulistas do Rio de Janeiro e de São Paulo revestia-se de outro significado, porque personificava-se na figura de um herdeiro do trono, persuadido a negar o chamado despotismo metropolitano para corroborar as reivindicações destes seus aliados que se auto nomeavam brasileiros. ${ }^{75}$

\footnotetext{
${ }^{72}$ José Bonifácio de Andrada e Silva. Representação dirigida ao príncipe Regente do Brasil pela Junta Provincial de São Paulo em 24 de dezembro de 1821. Disponível em www.obrabonifacio.com.br, p.20.

${ }^{73}$ José Bonifácio de Andrada e Silva. Representação dirigida ao Príncipe Regente do Brasil pela Vereança do Governo Provisório de São Paulo, em 31 de dezembro de 1821. Disponível em www.obrabonifacio.com.br, p.229.

${ }^{74}$ ARAUJO, Valdei Lopes de. A experiência do tempo: conceitos e narrativas na formação nacional brasileira (1813-1845). São Paulo: Editora HUCITEC, 2008. p. 63.

${ }^{75}$ É pertinente lembrar que D. Pedro, para além de todas as demais contingências, sensibilizou-se com as 8.000 assinaturas em favor de sua permanência no Brasil, e por ela decidiu em 9/01/1822.
} 
Para lamento dos que defendiam a conversão das dissidências em um só povo, reconhecer-se brasileiro, mesmo após a declaração de permanência de D. Pedro, continuava a ser uma percepção restrita aos aliados fluminenses, portanto, uma noção que permanecia sem alcançar as províncias do Norte. À medida em que o projeto de independência capitaneado por Bonifácio, agora Ministro do Reino e dos Estrangeiros, ${ }^{76}$ adquiria consistência e delineava um porvir centralizador, as regiões do Brasil alheias às determinações que se irradiavam do Rio de Janeiro, passariam a ser alvo de disputas armadas. Disputas que colocaram frente a frente as tropas locais apoiadas por destacamentos militares enviados de Portugal favoráveis à manutenção da submissão das províncias à Lisboa - e as forças militares que agiam em nome de D. Pedro - imbuídas da tarefa de cooptar e subordinar os outros projetos regionais ao projeto chancelado pelo Príncipe. ${ }^{77}$ José Bonifácio, em meio a esse turbilhão, converteria o ideal emancipacionista engendrado na Corte em um ideal geral, afirmando que "brasileiro é todo aquele que segue a nossa causa."78 Isto é, a causa da centralidade sob os auspícios do regente, o que, de alguma maneira, provocava as províncias do Norte a inflar a rejeição ao pertencimento daquilo que vinha, então, se definindo como Brasil.

No fervilhar dessas disputas em torno do pertencimento ou nãopertencimento das pátrias locais à pátria brasileira, tal qual definida por Bonifácio e seus aliados, se aprofundavam as divergências dentro do próprio universo dos grupos atuantes no Rio de Janeiro. Se até então coimbrãos e brasilienses ${ }^{79}$ haviam concordado em rechaçar a arbitrariedade das Cortes de Lisboa e em defender a proeminência do Rio de Janeiro, a partir de 1822 as diferenças em relação aos

\footnotetext{
76 José Bonifácio de Andrada e Silva fora nomeado Ministro do Reino e dos Estrangeiros no dia 18/01/1822, portanto apenas nove dias após declarada a permanência de D. Pedro. Ver: Projetos para o Brasil / José Bonifácio de Andrada e Silva: organização Miriam Dolhnikoff. São Paulo: Companhia das letras; Publifolha, 2000, p.17.

${ }^{77}$ MATTOS, Ilmar Rohloff. Construtores e herdeiros: a trama dos interesses na construção da unidade política. Texto apresentado ao Seminário Internacional "Independência do Brasil: história e historiografia. São Paulo, USP, 2004.

78 MATTOS, Ilmar Rohloff. Transmigrar - nove notas a propósito do Império do Brasil. In: PAMPLONA, Marco A. \& STUVEN, Ana Maria (orgs.). Estado e Nação no Brasil e no Chile ao longo do século XIX. Rio de Janeiro, Garamond, 2010, p.109.

${ }^{79}$ Coimbrãos seriam aqueles abastados integrantes das tradicionais famílias luso-americanas, que tiveram a oportunidade de atravessar o Atlântico para cursar seus estudos superiores na Universidade de Coimbra, entre eles destacam-se nomes como o do próprio José Bonifácio, José da Silva Lisboa e Hipólito José da Costa. Já os Brasilienses seriam os membros de grupos luso-americanos não tão enobrecidos, que completaram seus estudos nas poucas escolas brasílicas especializadas ou nos Seminários da porção americana do Império lusitano. A esse respeito ver: NEVES, Lúcia Maria Bastos Pereira das. Corcundas e constitucionais: a cultura política da Independência (1820-1822). RJ: Revan: FAPERJ, 2003.
} 
possíveis projetos políticos para um Brasil em definição e repleto de especificidades começariam a ficar mais evidentes. Joaquim Gonçalves Ledo e Januário da Cunha Barbosa, expoentes dos brasilienses e redatores do Revérbero Constitucional Fluminense, representariam as vozes mais enérgicas de um constitucionalismo representativo. De outro lado, os pares coimbrãos de José Bonifácio defendiam um constitucionalismo controlado ou, em outras palavras, regulado pelo monarca. A retórica do Revérbero de Ledo e de Cunha Barbosa evocou, desde os seus primeiros números, a defesa das liberdades individuais e da soberania dos povos, princípios que atravessavam a concepção constitucionalista que compartilhavam com parte significativa do contingente de letrados fluminenses formados nas Escolas e Seminários da América Portuguesa. No entanto, embora o viés constitucionalista que defendessem fosse substancialmente distinto daquele reverenciado pelo grupo coimbrão de Bonifácio, era um viés que operava dentro dos limites do arcabouço de uma Monarquia Constitucional, onde a soberania dos povos deveria ser regulada pelas instituições, de modo a garantir a estabilidade e evitar que, nas palavras dos próprios redatores do Revérbero fosse dada "uma latitude indefinida a esta Soberania (...) para que não degener[asse] em arbitrariedade.” 80

Enquanto nos arredores do Paço se davam as disputas em torno da definição das balizas legais do que viria a ser a monarquia brasílica, a muitos quilômetros dali aquelas incursões bélicas continuavam a ser realizadas. E o intuito das tropas de D. Pedro continuava a ser o de submeter as pátrias locais ao projeto centralizador que representavam. Para D. Pedro e seus Conselheiros, se tratava "não [da] causa de uma Província, [mas] da causa do Brasil.." ${ }^{\prime 1}$ Em manifesto assinado em $1^{\circ}$ de agosto de 1822, o herdeiro da Casa de Bragança atribuía a insubordinação das províncias do Norte "aos fardados Lobos, que ainda sustenta[va]m os sanguinários caprichos do partido faccioso", 82 assim sugerindo que os ditos territórios se libertassem dos maus portugueses que pretendiam mantê-los sob seu controle e aderissem à grande associação Política, "assina[ndo] o ato da nossa emancipação." ${ }^{83}$ A ideia de independência pautada pelo grupo dos Andrada ganhava, então, contornos cada vez

\footnotetext{
${ }^{80}$ Revérbero Constitucional Fluminense, $\mathrm{n}^{\circ}$ 10, 30 de julho de 1822, p.122.

${ }^{81}$ CARVALHO, José Murilo de; BASTOS, Lucia; BASILE, Marcelo (orgs.). Guerra literária: panfletos da independência (1820-1823). Vol.2: Análises. Belo Horizonte: Editora UFMG, 2014, p. 634.

${ }^{82}$ Ibid., p.633-4.

${ }^{83}$ Ibid., p. 634.
} 
mais precisos, sobretudo em função da hostilidade alimentada entre os defensores da causa dos que se autointitulavam brasileiros e aqueles identificados aos lisboetas. O manifesto de D. Pedro enunciava, em suas entrelinhas, que embora o projeto emancipacionista não significasse um rompimento formal com a ideia então compartilhada de nação portuguesa, ele cristalizava a noção de que uma outra identidade, que não mais aquela de português americano ${ }^{84}$ se configurava. Nessa esteira, Brasileiros seriam todos aqueles que cedessem, voluntária ou involuntariamente, à tutela de D. Pedro ${ }^{85} \mathrm{e}$, como o próprio príncipe bradava, "marcha[ssem] pela estrada da glória e prosperidade do Brasil, [o tendo] sempre à sua frente. $" 86$

Diante do avanço do grupo de Bonifácio e de suas concepções constitucionalistas, Joaquim Gonçalves Ledo escreveu e publicou no mesmo mês de agosto um Manifesto aos povos brasileiros onde refutava, ponto a ponto, toda a estrutura argumentativa do Manifesto do príncipe, acusando-o de ser um ambicioso e inexperiente mancebo iludido pelos conselhos de uma facção ${ }^{87} \mathrm{~A}$ retórica de Ledo contra aqueles a quem chamava de pérfidos e indignos sátrapas da família dos Bonifácios, se materializaria nas seguintes indagações:

E esta é a liberdade política, objeto dos vossos desvelos, e a que vós desejais reduzir esse bom povo, a quem enganais com os [ecos?] da liberdade? A isso é que vós chamas mancha da razão e da justiça[?] e poderá o homem Brasileiro escutar semelhantes impostores? E poderão eles durar muito tempo sobre o ignomioso trono da impostura e da ignorância? ${ }^{88}$

Com esse Manifesto, Ledo rompia com o projeto emancipacionista que vinha se demonstrando vitorioso, acusando-o de subterfugiar intenções despóticas. Incisivamente, criticava a postura do Príncipe e de seus aliados de fomentarem a rivalidade entre o que foi se convencionando identificar, em meio aos episódios que envolviam as províncias do Norte, como brasileiros ou como portugueses. Nesse momento, Gonçalves Ledo recua em relação à ideia de independência, já que no

\footnotetext{
${ }^{84}$ PIMENTA, João Paulo. Portugueses, americanos, brasileiros:identidades políticas na crise do Antigo Regime luso-americano. Revista Almanack Brasiliense, $\mathrm{n}^{\circ}$ 03, maio/2006.

${ }^{85}$ MATTOS, Ilmar Rohloff. Construtores e herdeiros: a trama dos interesses na construção da unidade política. Texto apresentado ao Seminário Internacional "Independência do Brasil: história e historiografia. São Paulo, USP, 2004, p.16.

${ }^{86}$ CARVALHO, José Murilo de; BASTOS, Lucia; BASILE, Marcelo (orgs.). Guerra literária: panfletos da independência (1820-1823). Vol.2: Análises. Belo Horizonte: Editora UFMG, 2014, p.634.

${ }^{87}$ Ibid., p. 615.

${ }^{88}$ Ibid., p. 617.
} 
seu entender, estava em curso um projeto que desvirtuaria a essência dos princípios de constitucionalismo e de soberania dos povos dos quais era defensor desde os primeiros números do Revérbero. Diante disso, assumiria uma postura surpreendente: tornou a advogar a favor da manutenção dos vínculos políticos do Brasil com Portugal. Afinal, naquele cenário, uma oposição consistente a D. Pedro só se efetivaria caso Ledo e seus aliados conseguissem arregimentar a seu favor os principais núcleos de resistência, de modo que constituíssem uma alternativa sólida ao projeto centralizador do Rio de Janeiro. O redator do Revérbero preferiria, portanto, dar um passo atrás e apoiar as províncias submetidas à Lisboa, do que compactuar com "os infames e ineptos conselheiros, (...) que quereis as instituições velhas, liberais a vosso modo, [que] desejais as Cortes das três Classes, em que o vil terceiro estado só pedia e suplicava." ${ }^{, 89} \mathrm{O}$ Manifesto parecia, assim, sugerir que uma outra via emancipacionista fosse se constituir a partir da aliança entre os fluminenses alheios à Bonifácio e os baianos, paraenses, maranhenses e cearenses. Nas palavras de Ledo, tal aliança, se concretizada, faria rugir o Leão da discórdia. ${ }^{90}$

A repercussão dessa querela seria imensa nos meses de setembro e outubro. Os jornais e folhetos se polarizariam: uns em defesa da retórica da ordem e da centralização, cara ao grupo de Bonifácio, e outros em apoio ao discurso da representatividade e da soberania dos povos, mobilizado pelo grupo de Ledo e Cunha Barbosa. Com a independência consumada, essas tensões só se aprofundariam. Em 2 de outubro, José Bonifácio já se queixaria, sem citar nomes, de "tramas infernais, que se urdem não só contra a Causa do Brasil, mas contra a preciosa vida de Sua Alteza Real, contra a [sua] e contra todos os honrados Cidadãos amigos da nossa Causa." ${ }^{\text {91 }}$ Os dias posteriores à festa de aclamação de D. Pedro - ocorrida em 12 de outubro - seriam de perseguição explícita ao grupo de Ledo. Na imprensa, os partidários dos Andradas associavam as reivindicações por soberania dos povos a concepções revolucionárias e anticonstitucionais. ${ }^{92}$ A edição do Revérbero preparada por Ledo e Cunha Barbosa para ser publicada em 15 de

\footnotetext{
${ }^{89}$ CARVALHO, José Murilo de; BASTOS, Lucia; BASILE, Marcelo (orgs.). Guerra literária: panfletos da independência (1820-1823). Vol.2: Análises. Belo Horizonte: Editora UFMG, 2014, p. 616-7.

${ }^{90}$ Ibid., p. 634.

${ }^{91}$ Ofício enviado por José Bonifácio ao Desembargador João Ignácio da Cunha, em 2/10/1822. Ver: Documentos relativos ao processo mandado instaurar por José Bonifácio contra Januário da Cunha Barbosa, Joaquim Gonçalves Ledo e outros. Fundação Biblioteca Nacional - Obras Raras. Notação: $39,0,22 \mathrm{~A}$

${ }^{92}$ CARVALHO, José Murilo de; BASTOS, Lucia; BASILE, Marcelo (orgs.)., op.cit., p.399.
} 
outubro, não chegaria a ser impressa pelas tipografias. Dias depois, por pressões de José Bonifácio, também seria proibida a circulação do Correio do Rio de Janeiro, dirigido por João Soares Lisboa. ${ }^{93}$ Entre meados de outubro e os primeiros dias de novembro, brotaram denúncias que atribuíam ao grupo de Ledo as qualificações de "malvados desorganizadores da boa ordem e conspiradores do governo

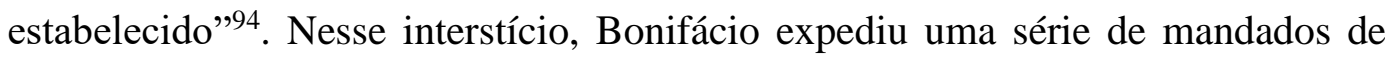
investigação e busca contra as locações que descrevia como "clubes secretos, com fins sinistros e inteiramente criminosos e abomináveis." 95 Neles se reuniam boa parte dos adeptos de Ledo, todos significativamente envolvidos com as atividades maçônicas, entre eles, José Clemente Pereira, então Presidente do Senado da Câmara. ${ }^{96}$ Em função das tensões em torno dessa contenda, o próprio Bonifácio se retiraria do Ministério. Seu afastamento não duraria mais do que dois dias. Reintegrado ao cargo pelo Imperador, José Bonifácio ganhava espaço e legitimidade suficiente para ordenar que nomes como os de João Soares Lisboa, Joaquim Gonçalves Ledo, Januário da Cunha Barbosa e do próprio José Clemente Pereira fossem:

(...) remov[idos] para fora da Cidade e seu termo, (...) os que se acham já acusados pela opinião Pública, assim como seus infames partidistas [sic] e mais pessoas compreendidas na facção ultimamente forjada contra o Governo, para que deste modo se possa proceder à competente Devassa sem aqueles obstáculos, que a presença deles poderia oferecer aos ânimos de seus acusadores.$^{97}$ (os grifos são do original)

Todos os denunciados ligados ao grupo do Revérbero seriam presos e exilados, à exceção de Gonçalves Ledo que conseguira fugir para Buenos Aires antes de ser capturado. A devassa obteria, então, o êxito de afastar da cena política

\footnotetext{
93 SILVA, Virgínia Rodrigues da. O Revérbero Constitucional Fluminense: imprensa $e$ constitucionalismo na Corte da Independência. Almanack Brasiliense, São Paulo, nº 10, p.171-179, nov.2009.

${ }^{94}$ Ofício enviado por José Bonifácio ao Desembargador João Ignácio da Cunha, em 6/11/1822. Ver: Documentos relativos ao processo mandado instaurar por José Bonifácio contra Januário da Cunha Barbosa, Joaquim Gonçalves Ledo e outros. Fundação Biblioteca Nacional - Obras Raras. Notação: $39,0,22 \mathrm{a}$.

${ }^{95}$ Ofício de José Bonifácio em 9/11/1822. Ver: Documentos relativos ao processo mandado instaurar por José Bonifácio contra Januário da Cunha Barbosa, Joaquim Gonçalves Ledo e outros. Fundação Biblioteca Nacional - Obras Raras. Notação: 39,0,22a.

${ }^{96}$ José Clemente Pereira seria, aliás, coagido por José Bonifácio a afastar-se do cargo de Presidente do Senado, diante do volume de críticas negativas que vinha desferindo contra ao grupo dos Andradas.

97 Oficio de José Bonifácio em 06/11/1822. Ver: Documentos relativos ao processo mandado instaurar por José Bonifácio contra Januário da Cunha Barbosa, Joaquim Gonçalves Ledo e outros. Fundação Biblioteca Nacional - Obras Raras. Notação: 39,0,22a.
} 
aqueles que, aos olhos do grupo de Bonifácio, configuravam uma ameaça ao Imperador. Um folheto alinhado à retórica situacionista, escrito entre novembro e dezembro de 1822, celebrava a vitória do que entendiam ser a ordem e o verdadeiro constitucionalismo. Assim se costurava a retórica do grupo de Bonifácio: se autorreferenciando como única possibilidade de defesa da ordem e acusando seus rivais de intenções supostamente democráticas e republicanas. $\mathrm{O}$ folheto em questão era exclamativo a esse respeito:

Amigos do Brasil! Vede os exemplos de Lima, talvez que a sorte desses infelizes Europeus fosse a vossa mesma sorte, se os facciosos chegassem a desenrolar a bandeira do seu partido anticonstitucional. União e tranquilidade é o que vos Recomendou a Nosso Augusto Imperador, Constituição Monárquica é o que todos esperamos: fora os ritos da Liturgia Grega, e Romana. ${ }^{98}$

O caminho se tornava, assim, menos tortuoso para que os Andradas afinassem as diretrizes da Constituinte em parceria com o Príncipe, afinal estavam silenciadas as vozes que haviam ousado flexibilizar as suas noções constitucionalistas. José Bonifácio e seus aliados só não poderiam supor o quão intransigente se mostraria, mais adiante, a personalidade do jovem monarca para lidar com as propostas reformistas do próprio Bonifácio em relação à condição na qual se encontravam negros e índios: alteridades fenotípicas e morais com as quais o projeto de Estado, orquestrado pela branquitude autorreferenciada como civilizada, precisava lidar.

\subsection{Da retórica civilizatória e da noção de aperfeiçoamento}

Os escritos de José Bonifácio, acerca do que entendia ser a situação de barbárie dos que identificava como negros e índios, permaneceriam em domínio privado por longo período, só vindo à público quando apresentadas, em meados 1823, à Assembleia Constituinte. Até então, Bonifácio estaria altamente envolvido nos tensos acontecimentos que acabaram por polarizar coimbrãos e brasilienses no eclipsar de 1822, além de estar diante de importantes desafios, como o de manter o território sob o controle central do Rio de janeiro, o de articular o reconhecimento

\footnotetext{
${ }^{98}$ CARVALHO, José Murilo de; BASTOS, Lucia; BASILE, Marcelo (orgs.). Guerra literária: panfletos da independência (1820-1823). Vol.2: Análises. Belo Horizonte: Editora UFMG, 2014, p.399.
} 
da independência no plano internacional, e o de fazer do Brasil um corpo político regulado por uma legislação própria. Só em 3 de maio de 1823 seriam inaugurados os trabalhos da Assembleia Geral Legislativa e Constituinte do Império do Brasil, integrada por deputados representantes das províncias. Nessa ocasião, D. Pedro já adiantava, coerente com o que havia declarado na cerimônia de sua coroação, que juraria a Constituição apenas se ela fosse digna do Brasil e de seu defensor - ele mesmo. ${ }^{99}$

O debate a respeito da representatividade efetiva dos constituintes se revestiria de nova roupagem: se antes havia sido personificado nas disputas entre o grupo dos Andradas e o de Joaquim Gonçalves Ledo - resultando no banimento do segundo grupo da cena política -, na ocasião da Constituinte de 1823 ele se materializaria em três frentes: os remanescentes das concepções de Ledo, os moderados capitaneados por Bonifácio, e um grupo de concepções mais centralizadoras. Esse último grupo que defendia a total subordinação dos constituintes ao Imperador vinha, por isso, ganhando mais espaço junto a ele. Em julho, as divergências políticas e pessoais entre os irmãos Andradas e D. Pedro teriam se agravado, culminando no pedido de demissão de Bonifácio do Ministério, o que teria contribuído para que ficasse disponível para ocupar a vaga de Deputado na Constituinte.

Como Deputado, Bonifácio apresentou à Assembleia a compilação de suas teses sobre dois temas congêneres que, há muito, constituíam objeto de suas elucubrações. A primeira a ser apresentada, ainda no mês de julho, seria a intitulada Apontamentos para a civilização dos índios bravos do Império do Brasil. ${ }^{100} \mathrm{O}$ diagnóstico ali apresentado, atribuía o que julgava ser a barbárie do fenótipo indígena aos equívocos cometidos pelas legislações anteriores e às estratégias de conversão mobilizadas. Há nesse texto, portanto, críticas explícitas à natureza das missões jesuítas e ao projeto colonizador empreendido pela Coroa portuguesa, bem como denúncias sobre o que Bonifácio descrevia como uma displicente atuação das autoridades coloniais em relação às determinações do Diretório.

\footnotetext{
99 CARVALHO, José Murilo de; BASTOS, Lucia; BASILE, Marcelo (orgs.). Guerra literária: panfletos da independência (1820-1823). Vol.1: Cartas. Belo Horizonte: Editora UFMG, 2014, p.33. 100 José Bonifácio de Andrada e Silva. Apontamentos para a civilização dos índios bravos do Império do Brasil. Organização Miriam Dolhnikoff. São Paulo: Companhia das letras; Publifolha, 2000.
} 
De acordo com os Apontamentos, o maior problema identificado por Bonifácio no trabalho dos missionários religiosos se referia ao isolamento no qual mantinham os povos cooptados pelas missões, sem os integrar à comunicação dos brancos. Além disso, o texto acusava os jesuítas de terem praticado - reiterando os argumentos mobilizados pela Coroa na ocasião de sua expulsão - uma teocracia absurda e interessada. ${ }^{101}$ Por outro lado, como que ilustrando os insucessos da legislação laica substitutiva do trabalho missionário, Bonifácio delatava que "nesses últimos tempos, em século tão alumiado como o nosso, na corte do Brasil foram os botocudos, e puris do Norte, e os bugres de Guarapava convertidos outra vez de prisioneiros de guerra em miseráveis escravos."102 No seu entender, a ocorrência da escravização de índios em pleno século XIX demonstrava o grau de inobservância das autoridades da América portuguesa em relação à condição jurídica dos povos identificados como indígenas. Pauta que remontava aos pressupostos filosófico-jurídicos que, desde a querela entre Sepúlveda e Las Casas, vinha consolidando a noção de que o branco/colonizador não poderia se valer da sua concepção de barbárie indígena para justificar/ ou mesmo naturalizar a escravização desses povos. ${ }^{103}$ No texto apresentado à Constituinte, Bonifácio, na esteira do amplo debate travado nos círculos da branquitude letrada em relação à submissão dos povos colonizados, reconheceria os revezes da retórica colonizadora/ cristianizadora. Quase que como em um exercício de autocrítica, admitia:

(...) com o pretexto de os fazermos cristãos, lhes temos feito e fazemos muitas injustiças, e crueldades. Faz horror refletir na rápida despovoação destes miseráveis depois que chegamos ao Brasil.(...) Calcula o padre Vieira que em trinta anos, pelas guerras, cativeiros, e moléstias, que lhes trouxeram os portugueses, eram mortos mais de dois milhões de índios. ${ }^{104}$

No desdobrar de suas alegações, Bonifácio diferenciaria os índios, como era de praxe no discurso europeu/colonizador, em duas categorias: os índios domésticos e os índios bravos. Nas palavras do Deputado, havia semelhanças entre o comportamento selvático dos índios bravos e o do animal silvestre seu

\footnotetext{
101 José Bonifácio de Andrada e Silva. Apontamentos para a civilização dos índios bravos do Império do Brasil. Organização Miriam Dolhnikoff. São Paulo: Companhia das letras; Publifolha, 2000 , p.50.

102 Ibid., p.51.

${ }^{103}$ GUTIERREZ, Jorge Luis. A controvérsia de Valladolid (1550): Aristóteles, os índios e a guerra justa. Revista USP, São Paulo, nº101, p.223-235. MAR/ABR/MAI 2014.

${ }^{104}$ José Bonifácio de Andrada e Silva., op.cit., p.50-1.
} 
companheiro. Entretanto, considerava a possibilidade de que, mesmo os encontrados nesse estado, pudessem ser aperfeiçoados. Em diálogo com o cabedal discursivo com o qual interagia e afinado, portanto, às redefinições das noções de hierarquização que vinham afiançando a possibilidade de melhoramento dos que viam como inferiores, afirmava que “(...) não se deve concluir que seja impossível converter estes bárbaros em homens civilizados: [afinal] mudadas as circunstâncias, mudam-se os costumes."

A responsabilidade de civilizar, ao tempo das conquistas nomeada como a missão de converter, constituía uma espécie de missão pedagógica dos povos brancos/europeus em relação aos povos que consideravam estar em estágio inferior de desenvolvimento. Como que acompanhado as atualizações impostas pelos saberes ilustrados, a retórica civilizatória, como desdobramento da ampla e secular retórica hierarquizadora dos povos, apresentaria a ação civilizatória como uma função benevolente para com as gentes alheias aos códigos de conduta europeus. Isto é, o variado leque de filósofos e de naturalistas, que incrementaram o legado da tradição de inferiorização dos não-brancos, agregaram ao repertório da branquitude o reconhecimento de que, para além dos índios, os negros também possuíam características humanas, o que lhes tornava passíveis de melhoramento. Em razão disso, aos povos europeus, supostamente investidos de um sinal distintivo, caberia o dever - ou o ônus - de os resgatar da crueldade, da ignorância e dos maus costumes, conduzindo-os pelo itinerário da civilização. Bonifácio comentaria, no próprio corpo do texto apresentado à Constituinte, sobre a resistência que havia em se admitir que os povos ditos selvagens fossem civilizáveis. Suas palavras expressam, ainda, as tensões inerentes a um tempo em que as noções de superação, progresso e mesmo de revolução vinham ganhando espaço no mundo lusófono, mas não sem encontrar entraves. Dizia ele:

(...) crê ainda hoje muita parte dos portugueses que o índio só tem figura humana, sem ser capaz de perfectibilidade. Eu sei que é difícil adquirir a sua confiança, e amor; porque, como já disse, eles nos odeiam, nos temem e podendo nos matam, e devoram. ${ }^{106}$

105 José Bonifácio de Andrada e Silva. Apontamentos para a civilização dos índios bravos do Império do Brasil. Organização Miriam Dolhnikoff. São Paulo: Companhia das letras; Publifolha, 2000, p.49.

${ }^{106}$ Ibid., p.50. 
A menção às garantias de que "os índios deviam gozar dos privilégios da raça europeia," 107 conforme estabelecia a legislação em vigor, servem de mote para que o texto retome o que seu autor considerava ser a inconstância das ações civilizatórias por parte da administração pública, assim como servem para que compare o diagnóstico de barbárie de índios e de negros. No que concernia ao índio bravo, defendia que seu estado de barbárie resultava de uma combinação de dois fatores: a dificuldade que o governo encontrava em organizar a ação civilizatória e a natureza abundante que os cercava, condição que, na sua interpretação como na de alguns naturalistas de renome, concorreria para que se constituíssem como seres carentes "de ideia de prosperidade, de desejos de distinções e vaidades sociais, [então consideradas] as molas poderosas que põem em atividade o homem civilizado." 108 A constante reprodução do olhar enviesado que associava os modos outros de estar no mundo à barbárie contribuiria para reforçar, entre a dita boa sociedade, a noção de que os ameríndios não possuíam qualquer tipo de autonomia sobre sua existência. Operando na chave de que os índios do Brasil eram povos atrasados, Bonifácio defendia que deveriam ser iniciados nos bons costumes, para que assim pudessem efetivamente alcançar a condição político-jurídica que a legislação formulada pelos povos supostamente adiantados, em tese, já lhes garantia. Já a interpretação que desenvolvera em relação à condição dos negros, relacionava o seu estado de barbárie, no nível mais objetivo do discurso, à escravidão. No entanto, em uma dimensão menos obvia, talvez mais subjetiva, deixaria aflorar suas concepções racialistas, concepções que atribuíam a condição de barbárie do negro não apenas à sua circunstancial exposição ao escravismo, mas também ao que seria, supostamente, determinado por sua raça. Expressão disso são alguns de seus escritos avulsos. Em um deles recomendava que, como estratégia para a integração das aldeias e melhoramento das raças, fosse incentivada “(...) a mistura por casamentos entre brancos e índios, índios e mulatos, mas não negros, para cruzar as raças; e acabar com a isolação das aldeias." ${ }^{109}$ (grifo meu)

\footnotetext{
107 José Bonifácio de Andrada e Silva. Apontamentos para a civilização dos índios bravos do Império do Brasil. Organização Miriam Dolhnikoff. São Paulo: Companhia das letras; Publifolha, 2000, p.52.

108 Ibid., p.48.

109 José Bonifácio de Andrada e Silva. Avulsos. Organização Miriam Dolhnikoff. São Paulo: Companhia das letras; Publifolha, 2000, p.65.
} 
Assim como costumava ocorrer em países onde o escravismo de africanos fora mobilizado como principal contingente de mão-de-obra, a retórica de Bonifácio constitui uma amostra da percepção dos letrados lusófonos que concordavam em conferir ao índio posição mais favorável que a dos negros no modelo de escalonamento racial que partilhavam. Uma colocação de Bonifácio em relação à suposta barbárie na qual permaneceriam os índios é bastante elucidativa a esse respeito, quando afirma que "a pobreza em que se acham, a ignorância por falta de educação e estímulos, e as vexações contínuas dos brancos os tornam tão abjetos e desprezíveis quanto os negros." 110

O tópico da mistura de raças parecia mesmo constituir uma estratégia em prol do que Bonifácio entendia como a necessidade de civilizar os habitantes do Brasil. Nas suas palavras, seria recomendável incentivar os matrimônios entre índios e brancos e mulatos. ${ }^{111}$ Repare-se que os negros são novamente interditados dessa estratégia específica de melhoramento. O branco, no entanto, é referenciado como elemento fenotípica e moralmente superior, encarregado de gerar descendentes os mais claros possíveis. Cabe observar que o mulato é visto por Bonifácio como um tipo médio, situado entre brancos e negros, condição que os tornaria, por sua herança branca, mais suscetíveis aos padrões civilizacionais e ao desenvolvimento intelectual. De todo modo, em acordo com as noções de escalonamento racial que compartilhava, Bonifácio sugeria a mistura do que considerava raças intermediárias - o índio e o mulato - com a raça entendida como superior, assim contribuindo para dissolver os traços e os modos não-brancos. De modo similar à defesa da miscigenação presente em Buffon e em Blumenbach, em Bonifácio a ideia de mistura aparece como um recurso assertivo, na medida em que a expectativa apontava para um futuro onde os mestiços nascidos tivessem menos horror à vida agrícola e industrial. ${ }^{112}$

Entre os meses de julho e agosto de 1823, José Bonifácio apresentaria sua segunda tese sobre o que considerava ser a temática de maior interesse para a

\footnotetext{
110 José Bonifácio de Andrada e Silva. Apontamentos para a civilização dos índios bravos do Império do Brasil. Organização Miriam Dolhnikoff. São Paulo: Companhia das letras; Publifolha, 2000, p.52.

${ }^{111}$ Em Bonifácio, os mulatos são vistos como um tipo intermediário entre os brancos e os negros. Por sua herança branca, seriam ainda mais suscetíveis aos padrões civilizacionais e ao desenvolvimento intelectual. Ver: José Bonifácio de Andrada e Silva. Civilização dos índios e coisas do Brasil. Organização Miriam Dolhnikoff. São Paulo: Companhia das letras; Publifolha, 2000, p.72.

112 Ibid., p.63.
} 
prosperidade futura deste Império. ${ }^{113}$ Sua Representação sobre a Escravatura, é iniciada com uma menção ao texto que havia apresentado anteriormente acerca da civilização geral dos índios do Brasil. Tal referência aos Apontamentos vem acompanhada de uma sentença que merece atenção, pois enuncia uma prospecção que, mais adiante, seria retomada e desenvolvida pelo mesmo Januário da Cunha Barbosa do Revérbero, só que no IHGB. ${ }^{114}$ Nas palavras de Bonifácio, “(...) os índios do Brasil [quando civilizados] farão com o andar do tempo inúteis os escravos", ${ }^{115}$ afirmativa que remetia justamente à noção de escalonamento compartilhada pelo mundo lusófono, já que insinuava uma preferência, um tanto quanto velada, pelos índios aos negros. Há um outro registro similar em um texto de Bonifácio intitulado Os índios são muito imaginativos. Nessa ocasião, a possibilidade de tornar a presença dos negros dispensável é mais uma vez aventada. A expectativa de um país dirigido por brancos e arado por índios parecia uma configuração interessante àquela branquitude lusófona que via no negro escravizado a representação do que havia de mais pejorativo em termos fenotípicos e morais. De acordo com Bonifácio, o exemplo do trabalho, deveria vir, no entanto, do próprio branco, pois:

(...)querer que os índios trabalhem com a enxada, e querer que sejam iguais aos brancos, quando só os negros trabalham com ela, é querer impossíveis comecemos por acostumar os portugueses aos trabalhos rurais da própria lavoura, com prêmios e instrução; então os índios os imitarão, e os negros da África não serão precisos -as raças se misturarão e se melhorarão. ${ }^{116}$ (os grifos são meus)

O entendimento compartilhado pelos autores da branquitude colonial acerca de suas alteridades ultramarinas seria atualizado pelos autores da geração da independência que proporiam, como já adiantamos, a noção de perfectibilidade. Contudo, no que se referia ao escalonamento racial de índios e negros suas noções sofreriam poucas atualizações. Diferentemente do que se verifica em alguns países hispano-americanos, onde houve pouca ou nenhuma escravização de pessoas de origem africana, no Brasil independente os patamares mais baixos dessa hierarquia

\footnotetext{
113 José Bonifácio de Andrada e Silva. Representação à Assembleia Geral Constituinte e Legislativa do Império do Brasil sobre a escravatura. Organização Miriam Dolhnikoff. São Paulo: Companhia das letras; Publifolha, 2000, p.23.

114 Tal peça discursiva de Januário da Cunha Barbosa será analisada no Capítulo 3 desta tese.

115 José Bonifácio de Andrada e Silva., op.cit., p.23.

116 José Bonifácio de Andrada e Silva. Os índios são muito imaginativos. Organização Miriam Dolhnikoff. São Paulo: Companhia das letras; Publifolha, 2000, p.72.
} 
continuariam a estar reservados aos negros e não aos índios. ${ }^{117}$ A compreensão dos índios como superiores aos negros teria começado a se forjar ainda no século XVI, na ocasião em que os povos americanos adquiriram status jurídico equivalente ao dos brancos em função de terem sido considerados vassalos do Rei. ${ }^{118}$ A aparente condição de igualdade teria contribuído, conforme já afiançamos na primeira parte deste capítulo, para que fossem percebidos como menos suscetíveis ao escravismo, quando comparados aos africanos. Para isso teria colaborado também a reificação dos africanos pelo discurso da branquitude judaico-cristã que, desde os primórdios das negociações entre traficantes europeus e negociantes da costa de África, os consideraram juridicamente distintos dos demais povos do mundo atlântico. Em virtude de tal conjunção de fatores, aos colonizadores lusófonos, teria parecido mais conveniente, ou mesmo mais viável, investir na escravização de africanos, do que investir na cooptação dos supostamente insubmissos ameríndios. Nos papéis avulsos de José Bonifácio, há uma colocação expressiva de como esse escalonamento racialista, que relegava os negros aos menores níveis de humanidade, ajudava a sustentar a sua escravização como algo legítimo. Embora fosse crítico à continuidade da escravidão, Bonifácio não escapava de reproduzir noções que atribuíam a suposta inferioridade do negro não apenas às variáveis externas, como o escravismo, mas a condicionantes inatos, então ditos raciais. Nas suas palavras:

Uma das causas, que concorre a perpetuar e piorar a escravidão dos negros, é a cor: um escravo romano, apenas livre, podia confundir o seu sangue com seus primeiros amos; mas o negro conserva indelevelmente um sinal de separação e de desprezo. Não só o escravo aqui é inferior ao amo, mas o negro o é também ao branco. ${ }^{119}$ (o grifo é meu)

A crítica à escravidão e o recurso a argumentos explicitamente racistas coexistiam em Bonifácio, assim, aliás, como em outros letrados decisivos para a conformação do Brasil, como Francisco de Sales Torres Homem e Bernardo Pereira

\footnotetext{
117 Cabe salientar que em alguns países latino-americanos, como os que mobilizaram os povos originários como mão-de-obra, os índios eram/são vistos nos mais baixos patamares de humanidade. A esse respeito, ver: CATELLI, Laura. Pintores criollos, pintura de castas y colonialismo interno: los discursos raciales de las agencias criollas en la Nueva España del periodo virreinal tardio Cuadernos del CILHA, vol. 13, núm. 2, 2012 Universidad Nacional de Cuyo Mendoza, Argentina. ${ }^{118}$ BETHENCOURT, Francisco. Racismos: das Cruzadas ao século XX. São Paulo: Companhia das Letras, 2018.

119 José Bonifácio de Andrada e Silva. Avulsos. Organização Miriam Dolhnikoff. São Paulo: Companhia das letras; Publifolha, 2000, p.44.
} 
de Vasconcelos. ${ }^{120}$ De todo modo, o diagnóstico realizado por Bonifácio acerca dos efeitos nocivos do escravismo é contundente. Sua atuação na Constituinte seria, inclusive, marcada pela disposição em tentar persuadir seus pares de que a prosperidade do Brasil dependeria fundamentalmente de três mudanças: a extirpação imediata de um tráfico tão bárbaro e carniceiro; a melhoria da sorte dos atuais cativos; e a progressiva emancipação de todas as criaturas humanas escravizadas. ${ }^{121}$

Operando uma espécie de reapropriação do discurso liberal, o texto da Representação enumerava uma série de comprometimentos civilizacionais derivados do escravismo. Um deles seria o declínio de todo o corpo social, uma vez que os próprios senhores de escravos se afastariam de suas virtudes e "vive[ria] na inércia, pois não se vi[ria] precisada pela fome ou pobreza a aperfeiçoar sua indústria, ou melhorar sua lavoura." 122 A crítica de Bonifácio se estenderia ao clero que, em muita parte ignorante e corrompido, se aproveitaria do trabalho escravo para acumular bens materiais e cederia aos vícios mundanos, formando "muitas vezes, das desgraçadas escravas um harém turco." ${ }^{23}$ De mais a mais, a sua compreensão era a de que a escravidão representava um entrave à plena civilização e ao desenvolvimento da nação, argumento que em muitos aspectos remontava à retórica liberal, sobretudo à ideia de que o escravismo, por estar associado ao atraso, estaria no polo oposto à ideia de civilização, de avanço e de progresso.

A argumentação de Bonifácio, embora parecesse ousada nas circunstâncias em que fora apresentada, em um horizonte de debate mais amplo era perfeitamente plausível. Se no Brasil a pauta da superação da escravatura encontrava significativa resistência, sobretudo entre os representantes políticos das classes senhoriais herdeiras do fenótipo e da moral colonizadora - nos países europeus pelos quais

\footnotetext{
120 Tais autores terão alguns de seus mais expressivos escritos analisados nos próximos capítulos. Cabe salientar que, o reconhecimento da dimensão racista dos escritos desses letrados ainda não constitui ponto pacífico na historiografia. De acordo com Barbara Weinstein, por exemplo, o que diferenciaria os argumentos escravistas do Brasil e os do sul dos EUA seria a ausência de enunciados explicitamente racistas por parte dos letrados brasileiros da primeira metade do século XIX, enquanto no Sul dos EUA as alegações racistas teriam servido para justificar a própria escravidão. A esse respeito, ver: WEINSTEIN, Barbara. Escravidão, cidadania e identidade nacional no Brasil e no Sul dos Estados Unidos. In: DOYLE, Don H. \& PAMPLONA, Marco A.V. Nacionalismo no Novo Mundo. RJ / SP: Editora Record, 2008.

${ }^{121}$ José Bonifácio de Andrada e Silva. Representação à Assembleia Geral Constituinte e Legislativa do Império do Brasil sobre a escravatura. Organização Miriam Dolhnikoff. São Paulo: Companhia das letras; Publifolha, 2000., p.23-4.

122 Ibid., p. 29.

${ }^{123}$ Ibid., p. 27
} 
Bonifácio circulou, ela constituía uma das mais urgentes agendas. Tanto que seus escritos mobilizavam experiências anglófonas bem-sucedidas de extinção do tráfico $^{124}$ e de supressão da escravidão, como exemplos de que tais mudanças também poderiam ser viáveis nesta borda do Atlântico. Nesse sentido, alegava que seria possível desmontar a estrutura escravista sem arruinar a economia do nascente país, atacando, assim, o cerne do discurso pró-escravista encarnado por grande parte dos latifundiários, senhores de engenho e negociantes de então. No entanto, sensível às circunstâncias políticas e cauteloso em relação à repercussão destas suas ideias, Bonifácio faria questão de esclarecer que "não desej[ava] ver abolida de repente a escravidão, [pois] tal acontecimento traria consigo grandes males."125

A curto prazo suas ideias pretendiam investir contra o tráfico. Já a extinção definitiva da escravidão aparecia nesses seus escritos como um horizonte necessário, porém distante. Na sua perspectiva, a extinção do comércio de seres humanos constituiria um primeiro passo na direção de uma nação efetivamente sintonizada com os valores apresentados pelo racionalismo setecentista, sobretudo no que dizia respeito aos direitos civis e às noções de cidadania. Aos seus pares Constituintes, alertava que o Brasil deveria se envergonhar de ser, em pleno 1823, “o único país de sangue europeu que ainda comercia[va] clara e publicamente em escravos africanos." ${ }^{126}$ Constatação que evidencia dois pontos relevantes: primeiro, a compreensão do Brasil como um braço europeu, ou como uma espécie de nação europeia nos trópicos. Leitura, aliás, partilhada entre os que conduziriam o Estado dali por diante, um Estado orquestrado por brancos, como que casualmente habitado por índios e negros. ${ }^{127} \mathrm{E}$, em segundo, a reiteração do argumento que associava a escravidão e, mais ainda o tráfico, ao atraso. Condição que em um cenário marcado por um entendimento linear e progressivo do tempo, expressava o retardo do Brasil em relação aos demais países e engessava, no entender de Bonifácio, as aspirações a estágios de desenvolvimento mais sofisticados.

\footnotetext{
${ }^{124}$ José Bonifácio faz referência ao Ato de 2 de março de 1807, aprovado pelo parlamento britânico, que aboliu o tráfico negreiro realizado por ingleses. Ver: José Bonifácio de Andrada e Silva. Representação à Assembleia Geral Constituinte e Legislativa do Império do Brasil sobre a escravatura. Organização Miriam Dolhnikoff. São Paulo: Companhia das letras; Publifolha, 2000, p. $23 ; 45$.

125 Ibid., p.31.

${ }^{126}$ Ibid., p. 24 .

${ }^{127}$ O ponto da redefinição do Estado após a abdicação de D. Pedro será desenvolvido no último capítulo desta tese.
} 
Talvez, as razões de tal posicionamento em relação ao tráfico e ao escravismo possam ser compreendidas se considerarmos os percursos de Bonifácio pela Europa justo à época em que as lutas por liberdade e direitos ganhavam as ruas. Como um homem do Antigo Regime português, bacharel em Filosofia Natural e Direito por Coimbra, ${ }^{128}$ Bonifácio chegaria a Paris em meio à efervescência revolucionária e à discussão em torno da incoerência entre a apologia da liberdade e a manutenção da escravidão. ${ }^{129}$ Em 1791, aliás, quando eclodiu a Revolução em São Domingo, Bonifácio encontrava-se em Paris. Num fluxo recíproco, a França da Declaração dos Direitos do Homem e do Cidadão e o Haiti das reivindicações por igualdade e cidadania ${ }^{130}$ irradiariam ideias e exemplos capazes de lançar luz sobre contradições da República Americana, de amedrontar as elites senhoriais dos países europeus escravagistas e de suas colônias, e de evidenciar as incoerências da própria França revolucionária. Bonifácio assistira de perto a tudo isso enquanto pesquisava na Escola Real de Minas de Paris. Ciente da circulação de ideias condenatórias do tráfico humano e da escravidão, das explícitas pressões diplomáticas britânicas e das sucessivas leis aprovadas nos EUA em prol da extinção do comércio transatlântico de escravos, só restaria a Bonifácio, anos depois, em um momento de definição regulatória para o Brasil que se definia como Estado, tentar persuadir seus pares de que a resistência em mudar denotaria um arcaísmo comprometedor.

À propósito, não seriam poucas as menções em seus textos aos Estados Unidos da América, sobretudo no que tangia às suas conformações jurídicas, legislativas e tributárias, que compunham, na percepção de Bonifácio, "um sistema completo de civilização [e] uma lição para o Brasil!" ${ }^{131}$ No que concernia à adoção do modelo republicano por seus contemporâneos setentrionais, o defensor ferrenho do modelo monarquico para o Brasil preferiria não tecer comentários. Afinal, em sua compreensão, para que as províncias americanas de língua portuguesa fossem

\footnotetext{
128 VARELA, Alex Gonçalves. Livros, leituras, impressos, bibliotecas e coleções na trajetória do naturalista e homem público José Bonifácio (1780-1838). In: FERREIRA, Tania Bessone da Cruz \& RIBEIRO, Gladys Sabiana \&GONÇALVES, Monique de Siqueira (orgs.). O oitocentos entre livros, livreiros, impressos, missivas e bibliotecas. São Paulo: Editora Alameda, 2013.

129 Bonifácio estudou na Escola Mineralógica de Paris entre os anos de 1790 e 1791. Ver: DOLHNIKOFF, Miriam (org.) José Bonifácio / Projetos para o Brasil. São Paulo: Companhia das letras; Publifolha, 2000, p.15.

${ }^{130}$ A respeito da mútua influência entre França e São Domingo, ver: GEGGUS, David. The Haitian Revolution in Atlantic perspective. In: CANNY, Nicholas \& MORGAN, Philip. The Oxford handbook of the Atlantic world. Oxford University Press.

131 José Bonifácio de Andrada e Silva. Avulsos. Organização Miriam Dolhnikoff. São Paulo: Companhia das Letras; Publifolha, 2000, p.75.
} 
mantidas sob controle do Governo central, havia a necessidade de um Executivo forte, preferencialmente exercido pelo monarca da dinastia de Bragança, capaz de impor, à revelia das pretensões regionais, seu projeto de um império de dimensões continentais. ${ }^{132}$ Isto é, expressão da apropriação do liberalismo por esses letrados articulistas da independência, os quais associavam a via republicana às experiências revolucionárias da França e de suas possessões atlânticas, vistas, então, como manifestações de um radicalismo exacerbado e de uma irreparável desordem social.

Se para Bonifácio, e mais adiante para Torres Homem, a República estadunidense constituía uma referência civilizacional em muitos aspectos, no que dizia respeito às garantias individuais, a permanência do escravismo lhes parecia uma falha, ou mesmo uma inadequação aos pressupostos civilizacionais. Sobre esse ponto de inflexão do modelo norte-americano, os escritos de Bonifácio destacavam seu caráter prejudicial ao pleno desenvolvimento material e moral da cultura e povoação, comparando o atraso dos estados das Carolinas, Virgínia, Georgia, Kentucky e Tenesse aos avanços dos estados antiescravistas. ${ }^{133}$ Nessa esteira, os Estados Unidos da América serviriam aos observadores como uma espécie de laboratório do escravismo, demonstrando, simultaneamente, os efeitos da opção pelo escravismo no Sul e os resultados do trabalho livre no Norte.

Aliás, havia um já consumado desapontamento entre alguns dos abolicionistas britânicos, como Richard Price e Thomas Day, com a inabilidade das Américas em superar o escravismo e adotar a mão-de-obra assalariada. ${ }^{134}$ Esses membros da Europeans Friends of Liberty manifestavam decepção em relação aos Founding Fathers que, diante da oportunidade construída pelo movimento de independência das Treze Colônias e pela edificação de uma nova ordem, não

\footnotetext{
${ }^{132}$ No texto final da Constituinte de 1823, redigido por Antônio Carlos de Andrada - irmão de José Bonifácio -, há artigo que reitera a indispensabilidade de um Executivo forte, embora não houvesse ali qualquer menção ao Poder Moderador mais adiante instituído por D. Pedro arbitrariamente. Vale lembrar que desde os tempos dos debates em torno da manutenção do Brasil como extensão americana de Portugal, Bonifácio já advogava em favor de um governo central forte regulado por uma constituição moderada. A esse respeito ver: CARVALHO, José Murilo de; BASTOS, Lucia; BASILE, Marcelo. Constitucionalismo, liberalismo, nação. In: CARVALHO, José Murilo de; BASTOS, Lucia; BASILE, Marcelo (orgs.). Guerra literária: panfletos da independência (18201823). Vol.2: Análises. Belo Horizonte: Editora UFMG, 2014. p.16-9. Ver também: SOUSA, Otávio Tarquínio de. José Bonifácio. Coleção Documentos Brasileiros. Livraria José Olympio Editora, Rio de Janeiro, 1972, p.199.

133 José Bonifácio de Andrada e Silva. Avulsos. Organização Miriam Dolhnikoff. São Paulo: Companhia das letras; Publifolha, 2000, p.44.

${ }^{134}$ NASH, Gary. Sparks from de Altar of '76. International repercussions and reconsiderations of the American Revolutions. In: ARMITAGE, David; SUBRAHMANYAM, Sanjay. The age of revolutions in global context. (1760-1840). London: Palgrave Macmillan, 2010, p.6.
} 
conseguiram dirimir o escravismo em um país que se erguia sobre a máxima da inalienabilidade dos direitos individuais. Em relação às ramificações meridionais do tráfico atlântico, os abolicionistas ligados a Europeans Friends of Liberty, muitos deles membros do Parlamento ou do corpo diplomático de seus países de origem, tentavam convencer as autoridades ibéricas a se alinharem à perspectiva liberal de crítica à escravatura. A intenção era a de que fossem persuadidos da estagnação social e econômica patente nas sociedades escravistas, indicando, aliás, que as alegações de ordem econômica possuíam maior potencial de surtir os efeitos esperados, do que se fossem utilizados argumentos de teor humanitário. Não obstante Em sua Representação, Bonifácio demonstraria alguma sensibilidade em relação ao despojamento humano ao qual eram submetidos pelo tráfico de carne humana. Eis um trecho no qual destaca a violência moral incutida na lógica escravista:

Ainda hoje perto de quarenta mil criaturas humanas são anualmente arrancadas da África, privadas de seus lares, de seus pais, filhos e irmãos, transportadas às nossas regiões, sem a menor esperança de respirarem outra vez os pátrios ares, e destinadas a trabalhar toda a vida debaixo do açoite cruel de seus senhores, elas, seus filhos, e os filhos de seus filhos para todo o sempre! Se os negros são homens como nós e não formam uma espécie de brutos animais, se sentem e pensam como nós, que quadro de dor e de miséria não apresentam eles à imaginação de qualquer homem sensível e cristão? ${ }^{135}$

Aqui ele reconhece um aspecto da expropriação dos africanos escravizados, que vinha sendo também explanado pelos abolicionistas britânicos. E, nessa esteira, parece perceber que a escravidão despojava a criatura humana escravizada de sua ancestralidade, pois rasgava seus vínculos com sua terra e com sua família, assim como os privava de desfrutar sua hereditariedade, porque condenava seus mais remotos descendentes a viverem em condições análogas às suas. Em muitas ocasiões, mulheres e homens escravizados se viam privados, muito prematuramente, da mútua convivência com seus filhos, experiência que, somada à perda de suas referências, configurava uma espécie de morte social ${ }^{136} \mathrm{~A}$ espoliação da liberdade extrapolava a condição jurídica de autonomia e a condição física de submissão.

\footnotetext{
135 José Bonifácio de Andrada e Silva. Representação à Assembleia Geral Constituinte e Legislativa do Império do Brasil sobre a escravatura. Organização Miriam Dolhnikoff. São Paulo: Companhia das letras; Publifolha, 2000, p.25.

${ }^{136} \mathrm{~A}$ respeito do conceito de morte social, ver: PATTERSON, Orlando. Slavery and social death: a comparative study. Harvard University Press, 1985.
} 
No âmbito diplomático, Bonifácio estava a par de que a extinção do tráfico ajudaria no processo de reconhecimento da Independência, sobretudo pelos britânicos. A esse respeito chegou a ser claramente alertado por Chamberlain, Cônsul britânico no Rio de Janeiro, sobre o quão positivo seria se o Brasil aprovasse a proibição do tráfico de escravos. ${ }^{137}$ A ciência de Bonifácio em relação aos interesses britânicos de combate ao tráfico é evidenciada pelo texto da Representação, quando chega a citar nominalmente os parlamentares ingleses William Wilbeforce (1759-1833) e Sir Thomas Fowel Buxton (1786-1845), como inspiradores personagens atuantes em favor da causa abolicionista, no contexto dos anos 1820. ${ }^{138}$ Para os abolicionistas anglófonos o combate extrapolava a questão do tráfico, pois entendiam ser premente demarcar que era preciso, ainda, persuadir o mundo atlântico de que a continuidade da prática do escravismo comprometeria o desenvolvimento civilizacional e que, por isso, deveria ser considerada ilegal o quanto antes.

No plano pessoal, as ideias com as quais dialogava também reverberavam. Em carta escrita a Tomás Antônio de Villa Nova Portugal, em 1820, relatava "trabalhar de dia e de noite e tudo isto com gente livre e alugada, sem precisar de escravatura que detesto."139 Três anos depois, na Constituinte procuraria demonstrar a seus congêneres Deputados a falibilidade de alguns dos pressupostos legitimadores do escravismo. O primeiro fundamento dos que chamava apologistas do escravismo a ser desconstruído por seus escritos é o de que os africanos seriam retirados de um clima e país ardente e horrível para viverem em um de clima fértil, doce e ameno, onde seriam apresentados às leis do evangelho. Bonifácio diz que tal alegação feria as leis eternas da justiça e da religião, pois camuflava, sob a justificativa da difusão da fé, as suas reais intenções de dominação e exploração. Um outro argumento atacado por Bonifácio fora o do direito de propriedade dos senhores sobre os escravos. Tal alegação, comumente mobilizada por aqueles que se sentiam ameaçados financeiramente pela crescente comoção em torno da

\footnotetext{
${ }^{137}$ SOUSA, Otávio Tarquínio de. José Bonifácio. Coleção Documentos Brasileiros. Livraria José Olympio Editora: RJ, 1972, p.178-9.

138 José Bonifácio de Andrada e Silva. Representação à Assembleia Geral Constituinte e Legislativa do Império do Brasil sobre a escravatura. Organização Miriam Dolhnikoff. São Paulo: Companhia das letras; Publifolha, 2000, p.23; 45.

139 Carta de José Bonifácio a Tomás Antonio de Vila Nova Portugal, escrita em 1820. Apud: SOUSA, Otávio Tarquínio de. José Bonifácio. Coleção Documentos Brasileiros. Livraria José Olympio Editora, Rio de Janeiro, 1972, p.178.
} 
libertação das pessoas escravizadas, consistia na premissa de que o escravo seria um bem material, assim como uma fazenda, ou alguns víveres. Isto é, uma retórica da inversão, onde as políticas de emancipação constituiriam um atentado aos princípios liberais, ao que Bonifácio rebatia, recuperando o longo debate sobre o reconhecimento da humanidade dos negros:

Não é, pois, o direito de propriedade que querem defender, é o direito da força, pois que o homem, não podendo ser coisa, não pode ser objeto de propriedade. Se a lei deve defender a propriedade, muito mais deve defender a liberdade pessoal dos homens, que não pode ser propriedade de ninguém, sem atacar os direitos da providência, que fez os homens livres, e não escravos; sem atacar a ordem moral das sociedades, que é execução estrita de todos os deveres prescritos pela natureza, pela religião e pela sã política. ${ }^{140}$

Com a mesma ênfase, Bonifácio combatia o que condenava como um uso anacrônico das regulações gregas e romanas para justificar o escravismo moderno. Nesse sentido, acusava de levianas as apropriações de referências clássicas no intuito de legitimar interesses circunstanciais. No seu entender, o Direito Romano servia para autorizar somente o escravismo do qual era coetâneo, já que o tráfico e a escravização exercidos no XIX se assentavam em bases completamente distintas das práticas da Antiguidade clássica. Por isso, aos que se apoiavam nessa linha para justificar o escravismo, advertia:

Fala pois contra vós a justiça e a religião, e só vós podeis escorar no bárbaro direito público das antigas nações, e principalmente na farragem das chamadas leis romanas: com efeito os apologistas da escravidão escudam-se com os gregos, e romanos, sem advertirem que entre os gregos e romanos não estavam ainda bem desenvolvidos e demonstrados os princípios eternos do direito natural, e os divinos preceitos da religião; e todavia como os escravos de então eram da mesma cor e origem dos senhores, e igualmente tinham a mesma, ou quase igual, civilização que a de seus amos, sua indústria, bom comportamento e talentos os habilitavam facilmente a merecer o amor de seus senhores e a consideração de outros homens; o que de nenhum modo pode[ria] acontecer em regra aos nativos africanos. ${ }^{141}$

O esforço retórico de Bonifácio parecia, portanto, ter como propósito persuadir seus pares legislativos de que a superação do tráfico e da atividade escravista seria condição indispensável à sua expectativa de que a sua inculta pátria de origem se tornasse uma nação efetivamente saudável e feliz. No entanto, suas ideias encontravam resistência na própria Constituinte, pois ali pairava uma espécie

\footnotetext{
140 José Bonifácio de Andrada e Silva. Representação à Assembleia Geral Constituinte e Legislativa do Império do Brasil sobre a escravatura. Organização Miriam Dolhnikoff. São Paulo: Companhia das letras; Publifolha, 2000, p. 30.

${ }^{141}$ Ibid., p.26.
} 
de conformismo em relação à continuidade do escravismo. A retórica mais frequente era a que reconhecia, por um lado, não ser profícuo manter o escravismo mas, por outro, sinalizava sobre a impossibilidade econômica de romper com tal prática. Ou seja, embora fossem capazes de admitir o arcaísmo implícito nas relações escravistas, bem como as mazelas delas decorrentes, defendiam a sua indispensabilidade econômica. Nesse sentido, sua superação não lhes parecia alcançável. Por isso, a luta de Bonifácio por demonstrar, na arena discursiva, que o país que se fundava seria profundamente onerado caso a inércia em relação à escravidão prevalecesse, pois para além de um presente já maculado pelo atraso, a reputação futura do país também estaria comprometida.

Talvez, por isso, seus escritos não tenham se resumido a diagnosticar o presente em diálogo com as críticas - e as heranças - do passado colonial. Eles apontariam caminhos, proporiam soluções que, no nível mais evidente do discurso, propunham estratégias para que a prática escravista fosse superada. Na hipótese de que o tráfico fosse extinto no prazo de quatro ou cinco anos, ${ }^{142}$ suas perspectivas para que o percurso das emancipações começasse a ser pavimentado se concentravam em duas frentes: a civilização dos libertos - então concebida na chave do aperfeiçoamento moral dos supostos inferiores - e a concomitante introdução de imigrantes - brancos - assalariados. Mas diante da resistência com a qual se deparava nas ocasiões em que os ditos temas eram discutidos, previa que "sem a abolição total do infame tráfico da escravatura africana, e sem a emancipação sucessiva dos atuais cativos, nunca o Brasil firmará a sua independência nacional; (...) e nunca aperfeiçoará as raças existentes."143

Afinado à ideia já levantada por Buffon de que o meio e a convivência influenciariam na definição moral dos povos, Bonifácio defendia que a presença de mão-de-obra branca assalariada em contato com os trabalhadores negros contribuiria para aperfeiçoar a moral do trabalhador negro escravizado, o que auxiliaria na transição para uma economia calcada na mão-de-obra livre. Ainda em outubro de 1822, Bonifácio escreveria a Felisberto Caldeira Brant, solicitando-lhe que enviasse trabalhadores rurais ingleses para fixarem residência no Brasil.

\footnotetext{
${ }^{142}$ O prazo para a extinção do tráfico consta no Artigo I do texto de Bonifácio sobre a escravatura. Ver: José Bonifácio de Andrada e Silva. Representação à Assembleia Geral Constituinte $e$ Legislativa do Império do Brasil sobre a escravatura. Organização Miriam Dolhnikoff. São Paulo: Companhia das letras; Publifolha, 2000, p.33.

${ }^{143}$ Ibid., p.41.
} 
Nomeado pelo próprio Bonifácio para atuar em Londres, Caldeira Brant não tardaria a se movimentar para cumprir a ordem do então Ministro dos Estrangeiros e repassaria a incumbência a um amigo seu, residente em Liverpool, esclarecendo que tal demanda se devia ao desejo "do Exmo. Senhor José Bonifácio de Andrada [de] convencer aos seus compatriotas por um exemplo prático que a cultura por braços livres é muito mais vantajosa do que a de escravos africanos." ${ }^{444}$ Os primeiros cinquenta trabalhadores livres chegaram aos portos do Brasil em janeiro de 1823. Em março, desembarcaram cerca de duzentos ingleses, que foram destinados às lavouras do Brasil. Amparado por ações experimentais de combate ao escravismo, em agosto, Bonifácio apresentaria sua Representação sobre a Escravatura à Constituinte.

Embora as propostas de emancipação dos escravizados ali apresentadas fossem correntemente interpretadas como oportunidades para a insurgência de levantes negros, o texto de Bonifácio revertia tal alegação, asseverando que a humilhação e a estagnação impostas aos escravizados é que alimentavam o desejo de fugas e de revoltas. O receio de Bonifácio sobre uma possível difusão do haitianismo se dava, portanto, em função da manutenção de parte significativa dos habitantes em cotidiano alijamento de sua dignidade e de seu pertencimento. ${ }^{145}$ Aliás, o diagnóstico de Bonifácio sobre seu tempo presente era o de que o escravismo produzia uma multidão de verdadeiros inimigos domésticos, que nada t[inha]m que perder ${ }^{146}$ por isso seu interesse em pleitear, diante da Assembleia, que o projeto de Constituição a ser elaborado levasse em conta a equiparação jurídica dos habitantes que fossem gradativamente emancipados. Assim, Bonifácio encaminhava soluções para o que lhe parecia ser um problema criado não apenas pela escravatura em si, mas também pela presença indesejável do negro. A extinção do tráfico serviria para estancar a entrada de novos negros, enquanto a ação civilizatória serviria para, na impossibilidade de os excluir, aperfeiçoar aos que já

\footnotetext{
${ }^{144}$ SOUSA, Otávio Tarquínio de. José Bonifácio. Coleção Documentos Brasileiros. Livraria José Olympio Editora, Rio de Janeiro, 1972, p.178.

${ }^{145}$ A respeito da menção que José Bonifácio faz à Revolução de São Domingo, ver: José Bonifácio de Andrada e Silva. Representação à Assembleia Geral Constituinte e Legislativa do Império do Brasil sobre a escravatura. Organização Miriam Dolhnikoff. São Paulo: Companhia das letras; Publifolha, 2000, p.41. Sobre o exemplo de São Domingo e a repercussão daquelas ideias no mundo atlântico, ver: GEGGUS, David. The Haitian Revolution in Atlantic perspective. In: CANNY, Nicholas \& MORGAN, Philip. The Oxford handbook of the Atlantic world. Oxford University Press. ${ }^{146}$ José Bonifácio de Andrada e Silva. Representação à Assembleia Geral Constituinte e Legislativa do Império do Brasil sobre a escravatura. Organização Miriam Dolhnikoff. São Paulo: Companhia das letras; Publifolha, 2000, p.41.
} 
estivessem no território do Império do Brasil. O trecho final de sua Representação é elucidativo a respeito desse prognóstico:

O mal está feito, senhores, mas não o aumentemos cada vez mais; ainda é tempo de emendar a mão. Acabando o infame comércio de escravatura, já que somos forçados pela razão política a tolerar a existência dos atuais escravos, cumpre em primeiro lugar favorecer a sua gradual emancipação, e antes que consigamos ver o nosso país livre de todo deste cancro, o que levará tempo, desde já abrandemos o sofrimento dos escravos. (...) Nós lhe daremos toda a civilização de que são capazes no seu desgraçado estado, despojando-os o menos que pudermos da dignidade de homens e cidadãos. Este é não só o nosso dever, mas o nosso maior interesse, porque só então conservando eles a esperança de virem a ser um dia nossos iguais em direitos, e começando a gozar desde já da liberdade e nobreza de alma, que só o vício é capaz de roubar-nos, eles nos servirão com fidelidade e amor; de inimigos se tornarão nossos amigos e clientes. ${ }^{147}$ (os grifos são meus)

As últimas linhas da citação deixam entrever que a retórica antiescravista de Bonifácio guarda um traço que seria comum a grande parte dos exercícios de escrita efetivados pela branquitude letrada disposta a argumentar contra a continuidade da escravidão na primeira metade do século XIX: que a extinção da escravidão não implicasse na alteração das hierarquias. Pois, mesmo que, no mais otimista dos prognósticos, os negros escravizados no Brasil fossem emancipados de seus senhores e tivessem a chance de tornarem-se cidadãos, continuariam a servir. $\mathrm{Ou}$, dizendo de outro modo, esse viés retórico procurava persuadir aos seus opositores de que a extinção da escravidão diminuiria o risco de levantes escravos e conservaria o seu contingente de serviçais, que deixariam de servir indignados para passarem a servir com fidelidade e amor.

De todo modo, o texto da Representação sobre a escravatura, bem como os Apontamentos sobre a civilização dos índios, apesar de incorporados ao projeto constitucional pelo relator Antônio Carlos Ribeiro de Andrada Machado e Silva irmão de José Bonifácio, ${ }^{148}$ encontrariam obstáculos cada vez mais significativos. No projeto constitucional apresentado no dia $1^{\circ}$ de setembro de 1823 constavam artigos relativos não só à criação de estabelecimentos destinados a catequizar e civilizar os índios, como também alguns concernentes à gradual emancipação dos escravizados e à regulação contratual das relações entre senhores e escravos. Tais

\footnotetext{
${ }^{147}$ José Bonifácio de Andrada e Silva. Representação à Assembleia Geral Constituinte e Legislativa do Império do Brasil sobre a escravatura. Organização Miriam Dolhnikoff. São Paulo: Companhia das letras; Publifolha, 2000, p.32.

148 SOUSA, Otávio Tarquínio de. José Bonifácio. Coleção Documentos Brasileiros. Livraria José Olympio Editora, Rio de Janeiro, 1972, p.197.
} 
proposições, sobretudo as encarregadas de repensar a indispensabilidade da escravidão, seriam vistas com reservas por alguns dos próprios Constituintes, bem como pelo Imperador.

A essa altura, o clima nas dependências parlamentares do edifício da Cadeia Velha já inspirava algum ceticismo entre os membros da comissão parlamentar que havia aprovado o dito texto. ${ }^{149}$ Entusiastas do Golpe da Vila Francada, que há pouco mais de três meses havia restaurado o absolutismo em Portugal, os Deputados que vinham se aproximando do Imperador, vinham articulando uma campanha de difamação dos Andradas pelo menos desde julho de 1823. Na impossibilidade de fazer retroagir a emancipação política do Brasil, o objetivo daqueles que Bonifácio chamava pejorativamente de pés de chumbo ${ }^{150}$ passou a ser o de atrair a confiança de D. Pedro, para que assim pudessem obter a chancela necessária às suas ambições burocráticas, comerciais, legislativas e até governativas. Entretanto, antes de cooptar o apoio do Imperador, seria preciso primeiro afastar seus antagonistas: os idealizadores da ruptura política com a península. E não haveria outro grupo mais representativo da chamada causa brasileira que o dos irmãos Andradas. Não por acaso, eles se tornariam, no desenrolar de 1823, o principal alvo dos mesmos portugueses que, por tempo considerável, se opuseram a D. Pedro -então atrelado a Bonifácio- incentivando a insubordinação das províncias do Norte ao projeto centralizador capitaneado pelo Rio de Janeiro.

Em meio a essas disputas, o Ministério liderado por Bonifácio fora demitido e em seu lugar nomeados alguns de seus desafetos. ${ }^{151}$ As desavenças palacianas não tardariam a chegar às páginas de alguns dos jornais sobreviventes às perseguições iniciadas em outubro de 1822, ironicamente perpetradas pelo próprio Bonifácio, contra aqueles que julgava serem representantes de um liberalismo radical, como

\footnotetext{
${ }^{149}$ Os sete Deputados que assinaram a versão do texto constitucional apresentado à apreciação da Assembleia em $1^{\circ}$ de setembro de 1823 foram: Antônio Carlos de Andrada, José Bonifácio de Andrada, José Ricardo da Costa Aguiar de Andrada, Antônio Luiz Pereira da Cunha, Manoel Ferreira da Câmara Bittencourt e Sá, Pedro de Araújo Lima e Francisco Moniz Tavares.

${ }^{150}$ Entrevista do Velho do Rossio concedida ao redator do jornal O Tamoio. Ver fac-símile da dita edição do jornal em: SOUSA, Otávio Tarquínio de. José Bonifácio. Coleção Documentos Brasileiros. Livraria José Olympio Editora, Rio de Janeiro, 1972.

${ }^{151} \mathrm{O}$ dito Ministério fora destituído em 16 de julho de 1823 . O novo gabinete nomeado pelo Imperador era integrado por: José Joaquim Carneiro de Campos, Caetano Pinto de Miranda Montenegro, Manoel Jacinto Nogueira da Gama, João Vieira de Carvalho e Luís da Cunha Moreira.
} 
Januário da Cunha Barbosa e Joaquim Gonçalves Ledo. ${ }^{152}$ Fazendo uso de argumentos similares àqueles mobilizados por Bonifácio no ano anterior para derrubar a reputação dos redatores do Revérbero Constitucional Fluminense, O Espelho ${ }^{153}$ e o Diário do Governo se dedicariam, então, a cunhar uma imagem negativa dos Andradas, acusando-os de se associarem a personalidades dissidentes, de verve republicana, ${ }^{154}$ que tentavam enfraquecer o Imperador insuflando a opinião pública contra a ordem estabelecida.

Já o Tamoio e o Sentinela da Liberdade à Beira-mar da Praia Grande sairiam em defesa de Bonifácio, de seus irmãos e dos Constituintes compactuados com suas ambições legislativas. Fundado em agosto de 1823, tendo como redatores França Miranda e Meneses Drumond - amigo pessoal de José Bonifácio - o jornal O Tamoio deixava claro, através de seu próprio nome a alusão à nação indígena que séculos antes havia se associado aos franceses para combater os portugueses. $O$ Tamoio atuaria durante três breves meses em defesa das pautas reivindicadas pelo Andradas como brasileiras, denunciando os ressentimentos dos portugueses em relação ao projeto que se rascunhava na Constituinte pelas mãos dos Andradas.

No dia seguinte à apresentação do projeto constitucional, O Tamoio publicaria uma entrevista feita com José Bonifácio. Nessas páginas da edição de dois de setembro, o ex-ministro já demonstrava certo conformismo em relação ao ridículo espalhafato do qual era alvo e já sinalizava que pretendia se retirar da vida pública. ${ }^{155}$ Ia ficando, então, evidente que os interesses então compreendidos como brasileiros estariam seriamente ameaçados pelas intenções dos portugueses - pés de chumbo- reminiscentes na Corte. Isto é, os grupos que haviam sido de alguma maneira derrotados pelo episódio do Dia do Fico e pelo decorrente rompimento com os adeptos da vertente recolonizadora das Cortes de Lisboa, pareciam ter recobrado o fôlego. Ao longo do mês de setembro, $O$ Tamoio e $O$ Sentinela seriam

\footnotetext{
${ }^{152} \mathrm{O}$ referido episódio, já desenvolvido em momento anterior deste capítulo, culminou no banimento do grupo de Gonçalves Ledo da cena política, sob a acusação de incitação ao republicanismo. Nos meses finais de 1822, alguns desses perseguidos pelo grupo de Bonifácio chegariam a ser presos e exilados, como fora o caso de Januário da Cunha Barbosa e José Clemente Pereira.

153 O Espelho, desde 1821, se configurava como um jornal comprometido em reproduzir as notícias da Corte sob o prisma oficial.

154 Tais críticas referiam-se, sobretudo, à participação de Antônio Carlos de Andrada e de Francisco Moniz Tavares na Revolução Pernambucana de 1817. Ambos eram Deputados da Constituinte e integravam a comissão que assinara o projeto constitucional apresentado em $1^{\circ}$ de setembro de 1823 . ${ }^{155}$ Entrevista do Velho do Rossio concedida ao jornal $O$ Tamoio, p.5. Ver fac-símile da dita edição do jornal em: SOUSA, Otávio Tarquínio de. José Bonifácio. Coleção Documentos Brasileiros. Livraria José Olympio Editora, Rio de Janeiro, 1972.
} 
acusados pelos Deputados aliados de D. Pedro de blasfemarem a imagem do Augusto Protetor da nação. Entre outubro e os dias iniciais de novembro, as pautas antiescravistas presentes no projeto constitucional seriam amplamente disseminadas como ameaçadoras da ordem estabelecida. O Imperador seria gradativamente convencido de que José Bonifácio o via como um imaturo pupilo e um frágil estadista. Um ofício seria, então, entregue aos Deputados da Constituinte pelo novo Ministro do Império e dos Estrangeiros, no qual estavam descritos os motivos pelos quais a Assembleia Constituinte e Legislativa constituiria uma ameaça ao país e ao Imperador. ${ }^{156}$ Duas exigências seriam feitas pelo novo Ministro, que era também coronel do Exército: a suspenção da liberdade de imprensa e a expulsão dos Andradas da Constituinte. A noite do dia onze para o dia doze de novembro fora de árduos trabalhos e de resistência dos Deputados, que já pressentiam a dissolução forçada da Assembleia. Incentivado por seus novos aliados, alheio às reivindicações dos Constituintes, o Imperador não hesitaria em confirmar, no próprio dia doze de novembro, o encerramento dos trabalhos da Assembleia Constituinte e Legislativa do Império do Brasil. Com essa atitude, afiançava o discurso de seus aliados e atribuía aos Andradas, outrora exaltados como fundadores do Brasil independente, a pecha de traidores do país.

As penalidades impostas aos supostos traidores não se restringiriam ao fechamento da Constituinte e à sua exclusão da vida pública, elas se encarregariam de descredibilizar um projeto que - longe de pretender corrigir a desigualdade procurava mitigar a ameaça que os povos não-brancos representavam à ocupação do território e à expectativa de uma nação coesa. Apesar de sua trajetória como naturalista e como homem público, por suas ideias, José Bonifácio seria preso e exilado. O fechamento da Constituinte e o exílio dos que defenderam a retórica liberal/ antiescravista/ civilizacional mais corrente entre os países ilustrados, deixaria para as próximas gerações uma marca, ou mesmo um recado sobre a força dos interesses senhoriais no Brasil.

\footnotetext{
${ }^{156} \mathrm{O}$ novo gabinete ministerial, do qual fazia parte Francisco Villela Barbosa como Ministro do Império e dos Estrangeiros, fora instituído pelo Imperador em 10/11/1823. O mencionado ofício fora entregue por ele aos Constituintes em 11/11/1823.
} 


\section{Quem constitui a paleta local?}

(...) a ficção está ligada à formação da subjetividade. (...) Assim, o controle do imaginário se traduz no controle $d a$ subjetividade. ${ }^{157}$

Gabriele Schwab

157 SCHWAB, Gabriele. Criando irrealidades: a mímeses como produção da diferença. In: In: GUMBRECHT, Hans Ulrich. \& ROCHA, João Cezar de Castro. Máscaras da mímeses: a obra de Luiz Costa Lima. Editora Record: RJ \&SP, 1999, p. 130. 


\subsection{Entre o exótico e o autêntico}

Os letrados envolvidos na elaboração do Brasil independente pretendiam ressignificar o imaginário da subserviência colonial, articulando as potenciais genuinidades brasileiras no intuito de alimentar a consciência da emancipação, distinguindo o novo país daquela identidade anterior de uma mera porção americana da nação portuguesa. ${ }^{158}$ A primeira Constituição teria desfrutado da oportunidade de estabelecer os crivos formais dessa emancipação brasileira, não fossem as articulações em nome de um projeto centralizador, em grande medida vinculado aos interesses dinásticos ambiciosos por manter, mesmo em um amplo contexto emancipacionista, o controle sobre esse novo Estado que surgia. Nesse sentido, a primeira Carta Magna do Brasil, ao demarcar as balizas legais do novo país, evidenciava os interesses envolvidos mais em conservar, do que em revolver as relações de poder cultivadas por três séculos de colonização. A presença ostensiva da simbologia metropolitana no cotidiano pouco ou nada alterado desde a anunciação da independência, geraria uma sensação de que o processo emancipatório não havia se completado. E à essa angústia da incompletude corresponderia a necessidade da reinvenção.

$\mathrm{Na}$ condição de enunciadas por letrados pertencentes à dita boa sociedade, ${ }^{159}$ tanto as constatações da incompletude, quanto as da necessidade de reinvenção do Brasil independente, possuíam limites bem definidos. E esses limites eram demarcados pela ideia de superação de um certo arcaísmo colonial relacionado, sobretudo, à escravidão e à toda prostração intelectual e industrial que dela decorreriam. Não havia, entretanto, muita preocupação dessas elites atuantes intelectualmente em meados da década de 1830, em criar estratégias para que

\footnotetext{
${ }^{158}$ Podemos assegurar que, pelo menos até a Revolução Liberal do Porto, em 1820, se preservava, entre os habitantes americanos do Reino de Portugal Brasil e Algarves, a noção de pertencimento ao Império português. Ou seja, para além das identidades regionais, configuradoras da ideia de pátria local, compartilhava-se a perspectiva de que todas essas pátrias constituíam partes integrantes da transoceânica nação portuguesa. A esse respeito, ver: PAMPLONA, Marco A. Pátria - Brasil. In: SEBÁSTIAN, Javier Fernandez (Dir.). Dicionario Politico y social del mundo ibero-americano. Tomo 8, Centro de Estudos Politicos y Constitucionales: Madrid, 2014. Ver também: PIMENTA, João Paulo. Portugueses, americanos, brasileiros: identidades políticas na crise do Antigo Regime luso-americano. Revista Almanack Brasiliense, nº 03, maio/2006.

${ }^{159}$ A expressão era recorrentemente utilizada entre os letrados da Corte - autorreferenciados como brancos civilizados - para definirem o grupo dos iniciados nas Letras, nas Artes e nas Ciências. A esse respeito, ver: MATTOS, Ilmar Rohloff de. O tempo Saquarema. São Paulo: HUCITEC, 1987.
} 
hierarquizações sociais, marcadamente racializadas, fossem também superadas. $\mathrm{O}$ que reivindicavam estava, portanto, relacionado, em linhas gerais, ao incremento das práticas civilizadas por parte da boa sociedade, no intuito de que o Brasil alçasse, para além da independência política, a sua independência intelectual, até então interditada, pela herança vista como nefasta da colonização. ${ }^{160}$

No desdobrar da abdicação um tanto inesperada de um D. Pedro I reincidentemente acusado de despotismo, ${ }^{161}$ o devir de um país unificado parecia constituir ponto pacífico entre os grupos letrados atuantes nos bastidores intelectuais e nas linhas de frente da política de um país então ameaçado de se fragmentar. A esses letrados, testemunhas oculares de que não bastaram os punhos centralizadores do Imperador para produzir a unidade pátria, caberia, então, a tarefa de estimular a formulação de estratégias sensíveis no sentido de fomentar o pertencimento a um Brasil que precisava se distanciar da referência lusitana para então alçar seus próprios voos. Enquanto a História do Brasil não fosse escrita, ou enquanto a trajetória literária nacional não fosse organizada, ou ainda, enquanto uma ópera brasileira não fosse composta, o que parecia se encarregar de garantir a unidade do Brasil era a manutenção, a todo custo, do território coeso e indivisível pelas forças monárquicas. Era como se a força centralizadora da Monarquia assumisse a função das subjetividades nacionais, então ausentes, em um país que cambaleava entre a tradição do pertencimento português e a invenção de uma outra nação. ${ }^{162}$

Pois um grupo de letrados brasileiros oriundos da boa sociedade, mas residentes em Paris, se dispôs, com certo pioneirismo, a assumir a empreitada de pensar e fazer Literatura a partir de uma perspectiva pátria, enfrentando, assim, a constatação geracional de que o Brasil não havia completado a sua independência, sobretudo no que se referia à sua soberania intelectual. Com essa intenção, Domingos José Gonçalves de Magalhães (1811-1882), Francisco de Salles TorresHomem (1812-1876) e Manoel de Araújo Porto-Alegre (1806-1879) idealizaram a

${ }^{160}$ Domingos José Gonçalves de Magalhães. Ensaio sobre a História da Literatura do Brasil. Nitheroy Revista Brasiliense, tomo I, 1836, p. 138.

${ }^{161}$ Cabe lembrar que D. Pedro I abdicou do trono em 7 de abril de 1831.

162 Wilma Peres Costa opera com este conceito de território, quando discute a opção pela Monarquia como estratégia das elites luso-brasileiras do Rio de Janeiro em prol da manutenção do legado territorial da América portuguesa. A esse respeito, ver: COSTA, Wilma Peres. Viajantes europeus e o escrever da nação brasileira. In: DOYLE, Don H. \& PAMPLONA, Marco A. Nacionalismo no Novo Mundo. Editora Record: RJ e SP, 2008, p.307. 
Nitheroy Revista Brasiliense. ${ }^{163}$ A publicação constituiria uma espécie de manifesto em favor de um país intelectualmente autônomo e economicamente alinhado às diretrizes liberais de um capitalismo cada vez mais sofisticado e, portanto, menos afeito ao tráfico de pessoas e às práticas do escravismo. ${ }^{164}$

Não que esforços semelhantes inexistissem, o próprio Gonçalves de Magalhães reconhecia o empenho do ilustre editor do Parnaso Brasileiro, Januário da Cunha Barbosa, ${ }^{165} \mathrm{em}$ tentar resgatar os nossos primeiros poetas, cuja herança é hoje nossa única glória. ${ }^{166}$ Mas a abordagem proposta pela Nitheroy, de fato, redimensionaria a autopercepção dos letrados brasileiros, sobretudo porque reivindicaria o fortalecimento identitário da autoria, exigindo, nas entrelinhas, que os letrados pátrios ocupassem os espaços interpretativos até então preenchidos por autores estrangeiros, já que, de acordo com as deduções do mesmo Gonçalves de Magalhães, nenhum nacional que nós conheçamos, ocupado se tem até hoje com tal objeto. ${ }^{167}$

Curiosamente, a redação e a publicação da Nitheroy, marcada por apelo pátrio tão contundente, ocorreu em terras estrangeiras, mais precisamente na mesma Paris onde viviam os reconhecidamente românticos Chateaubriand, Ferdinand Denis e Eugene Garay de Monglave. ${ }^{168}$ Isto porque diante da instabilidade conjuntural desencadeada pela renúncia de D. Pedro ao trono, os ainda jovens Magalhães, Torres Homem e Porto-Alegre decidiram embarcar para a França. A viagem não seria conjunta, haveria inclusive motivações e expectativas distintas. Manoel de Araújo Porto-Alegre foi o primeiro a emigrar ao referencial destino das

\footnotetext{
${ }^{163}$ Publicada em dois volumes, no ano de 1836, a Nitheroy Revista Brasiliense foi considerada pela historiografia da Literatura Brasileira como a pedra fundamental do Romantismo Brasileiro. Ver: BOSI, Alfredo. História concisa da Literatura Brasileira. $37^{a}$ edição, São Paulo: Cultrix, 1994. p.97. ${ }^{164} \mathrm{Na}$ perspectiva editorial da Nitheroy, o escravismo constituía um entrave ao desenvolvimento pleno do capitalismo no Brasil, principalmente porque acomodaria os proprietários de escravos, afastando o desejo de empreender, como também porque manteria parte significativa dos habitantes privados de recursos econômicos e inaptos a incrementar o mercado consumidor. Tema que será desenvolvido na última parte deste capítulo, a partir da análise do artigo de Francisco de Sales Torres Homem, publicado no $1^{\circ}$ volume da Nitheroy Revista Brasiliense, sob o título Considerações Econômicas sobre a Escravatura. Nitheroy Revista Brasiliense: Sciencias, Letras e Artes. Tomo I. Dauvin et Fontaine Libraires: Paris,1836, p.35-82.

165 O cônego Januário da Cunha Barbosa fora redator do Revérbero Constitucional Fluminense e, por isso mesmo, um dos protagonistas do cenário da independência. Dois anos mais tarde, em 1838, seria um dos dois fundadores do IHGB.

${ }^{166}$ Domingos José Gonçalves de Magalhães. Ensaio sobre a História da Literatura do Brasil. In: Nitheroy Revista Brasiliense: Sciencias, Letras e Artes. Tomo I. Dauvin et Fontaine Libraires: Paris, 1836, p. 137.

${ }^{167}$ Ibid., p.136.

168 BAREL, Ana Beatriz Demarchi. Um Romantismo à oeste: modelo francês, identidade nacional. São Paulo: Annablume, 2002.
} 
letras e das artes oitocentistas. Sua ida se deu entre os meses finais de 1831 e os iniciais de 1832, na companhia de Jean-Baptiste Debret, de quem já era discípulo na Escola Imperial de Belas Artes, no Rio de Janeiro. ${ }^{169}$ No ano seguinte à partida de Porto-Alegre, Gonçalves de Magalhães e Torres Homem, próximos desde a infância e formados pela mesma Faculdade de Medicina do Rio de Janeiro, partiriam para a capital francesa: Magalhães buscou por aulas de filosofia eclética e economia política, enquanto Torres Homem se dedicou ao estudo do Direito na Universidade de Paris. ${ }^{170}$

Esse Romantismo francófono de ressonância tropical guardava em sua essência um traço antitético aos iluminismos, sobretudo no que se referia às implicações mais radicais do liberalismo em solo francês. Chateaubriand, por exemplo, fez questão de manifestar seu horror ao sacrifício que a Revolução Francesa teria submetido a experiência, a tradição. Seus pares românticos, ao tecerem a retórica da sensibilidade, demarcavam a presença da inconsciência e da subjetividade frente à apologética racionalidade dos iluminismos e, assim, constituíam uma espécie de conservadorismo moderno,${ }^{171}$ crítico das experiências liberais mais agudas, mas entusiastas de processos alegadamente mais moderados, como os da Revolução Americana. ${ }^{172}$ É como se reconhecessem a legitimidade da ascensão das classes burguesas e as ruínas dos pilares do Antigo Regime, mas não tolerassem o banimento das fileiras aristocráticas dos espaços públicos, dos recintos de sociabilidade.

Um outro possível desdobramento deste anti-iluminismo implícito na retórica do Romantismo francófono seria o redimensionamento do olhar sobre o Novo Mundo. Embora icônicos autores, como Rousseau e Diderot, já sinalizassem

169 Jean-Baptiste Debret formou-se pela Academia de Belas Artes de Paris, em 1789. Filiado à tradição neoclássica, serviu como pintor de Estado à corte de Napoleão. Com o fim do Império Napoleônico, aderiu à Missão Artística Francesa que partiu para o Brasil em 1816. Permaneceu no país até 1831, ano em que retornou à França, levando consigo seu aluno Manoel de Araújo PortoAlegre.

${ }^{170}$ ANDRADE, Debora El-Jaick. Semeando os alicerces da nação: história, nacionalidade e cultura nas páginas da Revista Nitheroy. Revista Brasileira de História, SP, vol.29, n58, p.417-442. 2009. 171 A ideia de conservadorismo moderno que aqui fazemos menção remonta ao cenário resultante das primeiras rupturas ocasionadas pelo processo revolucionário francês, as quais interditaram uma série de privilégios da aristocracia em benefício de uma nova pauta de interesses burgueses. Diante disso, herdeiros dessas linhagens aristocráticas, como Chateaubriand, dedicavam-se a interpretar essa nova ordem, procurando preservar algum legado de seu modo de compreender o mundo, mas cientes da irreversibilidade das mudanças que a modernidade revolucionária lhes impunha. A esse respeito ver: HARTOG, François. Regimes de historicidade: presentismo e experiências do tempo. Belo Horizonte: Autêntica Editora, 2014.

172 Ibid. 
a respeito das agruras inerentes ao projeto civilizador tão caro à razão iluminista, ${ }^{173}$ o entendimento preponderante entre os demais pensadores desse contexto discursivo era o de que para além da civilização europeia o que havia eram ambientes inóspitos e populações degeneradas. A constituição desse imaginário, sobretudo acerca dos territórios americanos ao Sul da Linha do Equador, possui estreita relação com as descrições realizadas pelos viajantes-naturalistas. Ao longo do século XVIII, eles observariam, descreveriam e atribuiriam significado às rochas, às plantas, aos animais, ao clima e aos humanos que habitavam a essa porção um tanto enigmática do mundo.

Entre os séculos XVI e XVII, grosso modo, esse relato estava mediado pelo propósito catequizador ou, em outras palavras, permeado pelo ideal da conversão cristã, o que, de alguma maneira, já operava na lógica da superioridade intelectual, física e moral dos europeus, então travestidos de missionários, incumbidos de resgatar do suposto estágio de barbárie os habitantes nativos da América. ${ }^{174}$ Essa representação do Novo Mundo como lugar do exotismo, do fantástico e da anticivilização derivava, portanto, da mesma tradição discursiva e estética que, pelo menos desde o advento das Grandes Navegações, vinha elaborando uma espécie de hierarquização dos continentes, e sendo responsável por estabelecer uma noção de predominância europeia. ${ }^{175}$

Já no século XVIII, essa retórica da superioridade europeia, que é também a retórica da hegemonia branca/caucasiana, adquire uma nova diretriz: ela passa a ser corroborada pelo discurso da racionalidade, pois que absorvida pelo ofício do naturalista, que a tudo pretende classificar e catalogar, que a toda manifestação

\footnotetext{
${ }^{173}$ Cada qual a sua maneira, Rousseau e Diderot, constituíram experiências autorais capazes de, mesmo imersas no contexto linguístico dos Iluminismos, problematizarem a hegemonia da racionalidade, do progresso e da civilização. Em linhas gerais, seus questionamentos dirigiam-se, respectivamente, ao corrompimento da essência humana pela ambição civilizacional, e à nãolinearidade da vida humana, o que colocava em xeque a perspectiva teleológica das consciências ilustradas. A esse respeito, ver: GUMBRECHT, Hans Ulrich. Prose of the world: Denis Diderot and the periphery of the Enlightenment. Ver também: STAROBINSKI, Jean. Jean-Jacques Rousseau: $a$ transparência e o obstáculo. São Paulo: Companhia das Letras, 2011.

174 No Capítulo 1 desta tese procuramos recuperar o amplo debate, travado sobretudo entre missionários jesuítas e freis dominicanos, acerca do grau de humanidade dos nativos americanos e de sua maior ou menor inclinação à escravização. Não obstante, sobre essa contenda, ver: BETHENCOURT, Francisco. Racismos: das Cruzadas ao século XX. São Paulo: Companhia das Letras, 2018. Ver também: GUTIERREZ, Jorge Luís. A controvérsia de Valladolid (1550): Aristóteles, os índios e a guerra justa. Revista USP, São Paulo, nº101, p.223-235. MAR/ABR/MAI 2014.

175 GERBI, Antonello. O Novo Mundo: história de uma polêmica (1750-1900). São Paulo: Companhia das Letras, 1996.
} 
espontânea da natureza pretende atribuir um lugar na História Universal. Esse ofício, do qual Lineu foi um dos precursores, ${ }^{176}$ pressupunha a realização de expedições comprometidas a relatar, com o rigor exigido pelo cânone das academias naturalistas da época, tudo o que os olhos testemunhassem, fossem eles elementos animados ou inanimados da natureza. ${ }^{177}$ As anotações e as descrições que resultavam dessas expedições, traduziam as expectativas e os propósitos investigativos bastante característicos de um tempo em que a razão passava, portanto, a pretender controlar a natureza, não mais estando a mercê dela.

Este grandioso empreendimento do racionalismo ilustrado exigiu que um grande fluxo de naturalistas se deslocasse não só entre os países europeus, já em grande parte mapeados em suas especificidades ambientais, como também aos lugares tidos como inóspitos aos olhos desses mesmos viajantes. Aliás, seriam as narrativas dessas viagens ao Novo Mundo um dos gêneros que mais despertariam o interesse do público leitor europeu, em geral ávido por desvendar os mistérios de uma realidade distante e desconhecida e, por isso mesmo, já bastante propensa a idealizações e mistificações. Por mapear, contabilizar e descrever de seu lugar de fala um ambiente outro, pouco familiar a seus modos e gostos, esses naturalistas franceses, germânicos, ibéricos, ou escandinavos ${ }^{178}$ acabariam por, involuntariamente, referendar, através de seu discurso erudito, todas aquelas idealizações e mistificações já amplamente disseminadas no inconsciente coletivo. ${ }^{179}$

\footnotetext{
${ }^{176}$ Publicada em 1735, a obra Systema Naturae, de Lineu, constituiu um marco da sistematização da natureza, em suas mais variadas manifestações. A esse respeito, ver: BETHENCOURT, Francisco. Racismos. São Paulo, Companhia das letras, 2018, p.345.

${ }^{177}$ Em As palavras e as coisas, Foucault, propõe que o tempo de Lineu foi o tempo em que as palavras deixaram de constituir a coisa e "se tornaram modos de representação". Ou, em outras palavras, um tempo no qual o que o signo dizia sobre uma determinada coisa já não mais soava suficiente. Como sujeito desse tempo, Lineu "projeta[va] encontrar em todos os domínios concretos da natureza ou da sociedade as mesmas distribuições e a mesma ordem." FOUCAULT, Michel. As palavras e as coisas: uma arqueologia das ciências humanas. São Paulo, Martins, 2000, p.104-105.

${ }^{178}$ Havia uma espécie de rede transnacional de naturalistas, tecida a partir das Academias e de seus mecanismos de vinculação ao seu espaço de produção e compartilhamento do saber. Essa rede possibilitava a circulação de naturalistas das mais diversas origens europeias, bem como de naturalistas ibero-americanos afiliados às Universidades espanholas e portuguesas, como fora o caso de José Bonifácio em seu tempo de mineralogista afiliado e laureado por algumas das mais renomadas Academias europeias. A esse respeito, ver: SOUSA, Otávio Tarquínio de. José Bonifácio. Coleção Documentos Brasileiros. Livraria José Olympio Editora: RJ, 1972.

179 Ao problematizar as operações retóricas dos filósofos e naturalistas do século XVIII, Pierre Bourdieu diz tratar-se de uma mitologia científica, uma vez que se "funda na crença (ou no preconceito) que enviesa a ciência. (...) Esse discurso (...) deve sua existência e sua eficácia social ao fato de que, na era da ciência, a pulsão inconsciente que leva a dar a um problema socialmente importante uma resposta unitária e total, ao estilo do mito ou da religião, só se satisfaz tomando de
} 
Vejamos o caso de Montesquieu, ${ }^{180}$ que apesar de não ser propriamente um naturalista desbravador, foi uma das principais vozes da retórica iluminista francesa e desenvolveu uma das mais influenciadoras teorias sobre a implicação do clima na condição física e social dos seres humanos, reiterando, na esteira dos relatos das expedições de naturalistas, uma série de impressões estereotipadas compartilhadas pelo senso-comum francófono. ${ }^{181}$ Sua observação, ainda no prefácio de $O$ Espírito das Leis, de que "não extrai[u] [s]eus princípios de [s]eus preconceitos, mas da natureza das coisas" ${ }^{182}$ é, aliás, bastante sintomática a este respeito.

Convicto de sua imparcialidade, Montesquieu desenvolveria toda uma teoria da indissociabilidade entre a especificidade dos costumes e a formulação das leis e dos regimes políticos. Sua tese central era a de que as condições climáticas determinariam os costumes dos povos, e esses costumes, por sua vez, deveriam ser levados em consideração por todo governante, ou legislador que pretendesse uma condução social exitosa e coerente. A esse respeito, Montesquieu afirmava, categoricamente, que "as diferentes necessidades nos diferentes climas (...) formaram as diferentes maneiras de viver e são essas diferentes maneiras de viver que formaram os diversos tipos de leis." ${ }^{183}$ De acordo com suas elucubrações, crivadas por aguda racialização, nos países quentes, sobretudo os do Sul, a fraqueza, o medo e a inclinação aos prazeres seriam características comuns aos seus habitantes.

Atravessando toda a sua obra, a hipótese da inferioridade biológica não era aleatória, ela se baseava em estudos contemporâneos que atestavam a ação da temperatura sobre as fibras dos organismos. De acordo com essa teoria das fibras, ${ }^{184}$ o calor, ao dilatar as fibras e alongá-las, dificultaria o retorno do sangue das extremidades ao coração, enquanto nos climas frios, de modo antagônico, as fibras/os tecidos, por estarem comprimidos pela ação das baixas temperaturas,

empréstimo maneiras cientificas de pensamento e de expressão." Ver: BOURDIEU, Pierre. A economia das trocas linguísticas. São Paulo: EDUSP, 1996. p.178.

${ }^{180}$ Charles-Louis de Secondat, barão de la Brède e de Montesquieu viveu entre 1689 e 1755. Do espírito das Leis, publicado em 1748, foi escrito ao longo de vinte anos, sendo a última das obras do autor, que já havia publicado Cartas Persas em 1721.

${ }^{181}$ BOURDIEU, Pierre. A economia das trocas linguísticas. São Paulo: EDUSP, 1996.

182 MONTESQUIEU. Do Espírito das Leis. Coleção Os Pensadores, São Paulo: Abril S.A, $1^{\mathrm{a}}$ Edição, 1973, p. 27.

183 Ibid., p.209.

${ }^{184}$ A Teoria das fibras teria sido retomada e desenvolvida nos termos em que Montesquieu mobiliza pelo médico e matemático John Arburthnot (1667-1735). A esse respeito, ver: BOURDIEU, Pierre. A economia das trocas linguísticas. São Paulo: EDUSP, 1996. 
fariam o sangue circular com mais eficiência. Assim, Montesquieu mobilizava constatações de ordem fisiológica para justificar algumas das hierarquizações já bastante difundidas à época, ${ }^{185}$ mas agora em novos termos. Nessa direção, suas ilações sugeriam que:

O calor do clima pode ser tão excessivo que o corpo ficará totalmente sem força. Então o desânimo atingirá o próprio espírito; nenhuma curiosidade, nenhum nobre empreendimento, nenhum sentimento generoso; as disposições serão todas passivas; a preguiça será a felicidade; a maioria dos castigos serão menos difíceis de sustentar do que a ação da alma, e a servidão menos insuportável do que a força do espírito que é necessária para conduzir a si mesmo. ${ }^{186}$

O teor da construção argumentativa de Montesquieu remonta, portanto, ao universalismo característico da tradição iluminista, cujo cerne expressava a inabilidade do discurso europeu em reconhecer a diferença, em legitimar o outro em suas especificidades. ${ }^{187}$ Nesse contexto linguístico da Ilustração francófona havia, portanto, condições para que fosse possível, inclusive, atribuir aos efeitos do clima a razão pela qual alguns povos seriam mais predispostos à escravidão do que outros. $^{188}$ Montesquieu, por sinal, imputava ao conformismo e à inércia supostamente inerentes aos povos de climas quentes a sua tolerância em relação à servidão. A propósito, suas observações a esse respeito, remetem, implicitamente, aos descendentes amaldiçoados de Cam, ${ }^{189}$ sobretudo na ocasião em que afirma estar "a África (...) situada num clima semelhante ao do Sul da Ásia e encontra[r]se [por isso] sob uma mesma servidão." 190

\footnotetext{
185 Apenas um ano depois da publicação Do Espírito das Leis por Montesquieu, Buffon publicaria o primeiro volume de Histoire Naturelle, obra na qual explorava a possível relação entre o ambiente e a definição do caráter dos povos.

${ }^{186}$ MONTESQUIEU. Do Espírito das Leis. Livro XIV, Capítulo II. Coleção Os Pensadores, São Paulo: Abril S.A, $1^{\text {a }}$ Edição, 1973, p. 210-211.

${ }^{187}$ A esse respeito Bourdieu afirma que "a tradição letrada faz parte das condições sociais de possibilidade do mito erudito, de sua forma, isto é, da linguagem de aparência cientifica da qual se reveste." BOURDIEU, Pierre. A economia das trocas linguísticas. São Paulo: EDUSP, 1996, p. 184.Ver também: TODOROV, Tzvetan. Nós e os outros: a reflexão francesa sobre a diversidade humana. Rio de Janeiro: Jorge Zahar Ed., 1993, p.184.

${ }^{188}$ Com Pocock entendemos o quão condicional e, ao mesmo tempo, condicionada é a linguagem. Num movimento constante, o arcabouço linguístico determina o que pode ser dito, mas também se redefine constantemente a partir do que é inovadoramente enunciado. POCOCK, J.G.A. Linguagens do ideário político. São Paulo: Edusp, 2003. No mesmo sentido, Bourdieu sinaliza que "as fantasias sociais que o inconsciente cultivado do escritor engendra estão garantidas pela cumplicidade e pela docilidade de uma língua e de uma cultura que são o produto acumulado ao longo do tempo de um mesmo inconsciente social." BOURDIEU, Pierre. A retórica da cientificidade. In: A economia das trocas linguísticas. São Paulo: EDUSP, 1996, p. 184.

${ }^{189}$ Cabe reiterar que os descendentes de Cam seriam os povos do Sul e do Leste.

${ }^{190}$ MONTESQUIEU. Do Espírito das Leis. Livro XVII, Capítulo VII. Coleção Os Pensadores, São Paulo: Abril S.A, $1^{\mathrm{a}}$ Edição, 1973, p. 251.
} 
Diante desse legado, não seria involuntária a apropriação de Rousseau - um crítico de seu próprio contexto- pelo Romantismo: seus apontamentos acerca da virtuosidade do homem natural e suas provocações em relação aos vícios físicos e morais do homem civilizado fariam bastante sentido ao movimento em curso, sobretudo porque ofereceriam aporte à interpretação que se vulgarizava do selvagem como elemento puro, jamais exposto às disputas ególatras e à corrupção dos europeus civilizados. ${ }^{191}$ Nas primeiras décadas do século XIX, essa abordagem ganharia ainda mais espaço à medida em que novas narrativas sobre o Novo Mundo, cunhadas a partir de expedições realizadas por viajantes das mais diversas origens, passavam a circular e a produzir significativo apelo nas comunidades letradas europeias.

Desde a publicação de Viagem à América, de Humboldt, o olhar para o Novo Mundo se redefiniu. De formação naturalista, o parceiro de estudos de José Bonifácio não se furtaria a enxergar para além do Systema Naturae. ${ }^{192}$ A narrativa que costurou a partir das anotações de seus diários de viagem, inauguraria uma nova percepção sobre a paisagem e os habitantes do Novo Mundo. Depois dele, muitos foram ainda os que se aventuraram por esta porção meridional da América. Alguns de modo autônomo, como Chateaubriand, Ferdinand Denis e Maria Graham, ${ }^{193}$ outros integrando expedições de maior vulto, financiadas por acordos diplomáticos selados entre seus Estados de origem e a Corte d. João VI e, mais adiante, firmados com o Império do Brasil, como ocorreu com a Missão Francesa - da qual faziam parte Jean-Baptiste Debret, Nicolas-Antoine Taunay e Gradjean de Montgny- ${ }^{194}$,

191 STAROBINSKI, Jean. Jean-Jacques Rousseau: a transparência e o obstáculo. São Paulo: Companhia das Letras, 2011.

192 Conforme destacado no Capítulo 1 desta tese, José Bonifácio e Alexandre von Humboldt estudaram juntos entre 1792 e 1794 em Freiberg, onde foram discípulos do geólogo Abraham Gottlob Werner. A esse respeito ver: SOUSA, Otávio Tarquínio de. José Bonifácio. Coleção Documentos Brasileiros. Livraria José Olympio Editora, Rio de Janeiro, 1972, p. 26-7.

${ }^{193}$ Sobre as viagens e descrições de Ferdinand Denis sobre o Brasil, ver: OLIVEIRA, Maria Edith M. de A. R. de. O país do futuro e o futuro do país: as contribuições de Ferdinand Denis e Von Martius. Anais do $7^{\circ}$. Seminário Brasileiro de História da Historiografia - Teoria da história e história da historiografia: diálogos Brasil-Alemanha. Ouro Preto: EdUFOP, 2013. (ISBN: 978-85288-0326-6); ver também: PAMPLONA, Marco A. Considerações sobre a alteridade nos Diários de Maria Graham durante o período de residência no Chile (1821-1822) e breves comentários sobre suas viagens ao Brasil (1821, 1822 e 1823). IN: FALCON, Francisco José Calazans, CARVALHO, Marieta Pinheiro de e SARMIENTO, Érica (orgs.) Relações de poder no mundo ibero-americano: séculos XVIII-XIX. RJ: Autografia Ed. E Comunicação Ltda., 2019.

194 Aportando no Rio de Janeiro em 1816, a Missão Artística Francesa instituiu - com aval e financiamento de D. João VI - o Ensino Superior de Belas Artes na cidade então sede do Império português, A Escola Nacional de Belas Artes seria o espaço responsável pelo frutífero encontro entre o estudante Manoel de Araújo Porto-Alegre e o célebre pintor neoclássico Debret, encontro este que 
com a Missão Bávara - integrada pelos naturalistas Johann Baptiste von Spix e Carl Friedrich Phillip von Martius-, ${ }^{195}$ e com a Missão Russa - coordenada pelo médico Georg Heinrich von Langsdorff. ${ }^{196}$

Com efeito, o caráter dissidente das ideias apresentadas por Rousseau em meio a um contexto discursivo imerso no etnocentrismo ressoaria pelas próximas gerações e inspiraria, sem renunciar ao universalismo, ou ainda à monogenia, ${ }^{197}$ essa guinada nos anos iniciais do século XIX. Na esteira dessa reordenação do discurso branco europeu sobre o outro, Johann Baptiste von Spix e Karl Friedrich Phillip von Martius percorreriam juntos o território do recém formado Império do Brasil, o qual, de acordo com suas expectativas, "oferec[ia] ainda vasto campo ao espírito empreendedor de pesquisas [já que as informações das quais dispunham, indicavam que] era pouco povoado e conhecido, embora [fosse] ele coração desse novo continente." 198

O abastado conjunto de anotações e ilustrações que reuniram ao longo dos três anos em que atravessaram do Rio de Janeiro ao Amazonas originariam uma das mais celebradas publicações da década de 1820: Viagem pelo Brasil. Publicada inicialmente em quatro livros, que narram o simultâneo encantamento e estranhamento da dupla de naturalistas pelas cidades do Rio de Janeiro, São Paulo e Vila Rica, ${ }^{199}$ a obra extrapola o aspecto descritivo e transborda em uma persuasiva narrativa, hábil tanto em conduzir o leitor pelas trilhas da exuberante paisagem,

renderia uma longa parceria e que levaria Porto-Alegre à Paris justamente à época em que Gonçalves de Magalhães e Torres Homens também se estabeleceram por lá.

195 A comitiva bávara chegou à América portuguesa em 1817, trazendo também a arquiduquesa austríaca, Carolina Josefa Leopoldina - destinada a casar-se com D. Pedro, ainda príncipe. Os renomados naturalistas bávaros, que a acompanhavam, eram filiados à Academia de Ciências da Baviera e tinham como objetivo explorar os aspectos botânicos e zoológicos do que consideravam o país mais belo e rico da América.

196 A Missão Russa, chefiada por Von Langsdorff, percorreu o território do Império do Brasil por cinco anos, mais precisamente entre 1824 e 1829 ,

197 A monogenia, enquanto vertente defensora da origem comum dos seres humanos, é aqui problematizada em sua proximidade com a perspectiva universalista tão em voga no século XVIII, sobretudo porque, embora não supere as concepções hierarquizadoras dos diferentes fenótipos humanos, parece compartilhar da prerrogativa universalista de que toda manifestação da natureza, incluindo a humanidade em todas as suas variações, estariam submetidas a uma mesma moral.

198 K.F.P. von Martius \& J.B. von Spix. Viagem pelo Brasil. $1^{\circ}$ vol. Rio de janeiro: Imprensa Nacional, 1938, p.7.

199 Os três volumes publicados em 1823 referem-se à narrativa da viagem. Eles se desdobrariam em muitos outros volumes publicados até 1831, dedicados mais detidamente aos domínios da botânica e da zoologia. A esse respeito ver a Advertência de José Honório Rodrigues à edição de 1956 da dissertação: Como se deve escrever a História do Brasil, escrita pelo mesmo Von Martius e premiada pelo IHGB em 1845. Revista de Historia de América, No. 42 (Dec., 1956), pp. 433-458. Publicado por: Pan American Institut of Geography and History Stable. http://www.jstor.org/stable/20137096. 
quanto em tentar elucidar para o público europeu, a complexa trama étnica da qual descendiam os habitantes desse Brasil de 1817. Isto porque, as investigações zoológicas das quais Spix estava encarregado, compreendiam, para além dos - hoje óbvios - seres animais, também os seres humanos, pois de acordo com os preâmbulos à narrativa da Viagem, este domínio da zoologia "incluía tudo o que dizia respeito ao homem, tanto indígenas, como imigrados: as diversidades conforme os climas; o seu estado físico e espiritual, etc.” ${ }^{200}$ Tal observação em relação ao clima como marcador da aparência e do caráter dos habitantes, remonta a toda àquela tradição retórica que, amparada no determinismo espacial, atestava a superioridade fenotípica e moral dos brancos/europeus, tal qual sugeriram Montesquieu e Buffon.

Nesse sentido, von Spix e von Martius, embora já integrassem um contexto discursivo capaz de reconhecer na diferença paisagística a exuberância, demonstram-se significativamente atravessados por aquele universalismo etnocêntrico, quando o tema são as variações humanas. À proposito, suas justificativas para o tímido desenvolvimento das artes e das ciências nesta porção Sul do planeta seriam muito similares às do autor de $O$ Espírito das Leis, segundo o qual, conforme já discorremos, o calor deformaria não apenas as fibras corpóreas, mas a personalidade, conduzindo ao conformismo e à prostração. Ao narrar o estado do desenvolvimento populacional do Rio de janeiro, Spix e Martius, aliando suas referências cientificas às suas observações in loco, constatavam:

Até aqui tem sido antes o gosto pelas comodidades, pelo luxo e pelas formas agradáveis da vida exterior, que aqui se espalhou rapidamente, do que o amor pelas artes e pelas ciências no sentido liberal. Enquanto a formação destas últimas nos países do norte teve mais tarde, como consequência, enobrecimento dos gozos da vida, no sul, ao contrário, com desenvolvimento mais livre da sensualidade e da vida exterior, tarda o aperfeiçoamento das artes e das ciências. ${ }^{201}$

De todo modo, cabe reiterar que a persistência desse olhar etnocêntrico sobre o outro, nas narrativas dos viajantes do século XIX, não pode ser dissociada das convicções profundamente enraizadas no imaginário dos homens de ciências e de letras, que mesmo diante das incertezas colocadas por eventos da dimensão da Revolução Francesa e da Revolução do Haiti, ainda se identificavam com aquela

\footnotetext{
${ }^{200}$ K.F.P. von Martius \& J.B. von Spix. Viagem pelo Brasil. $1^{\circ}$ vol. Rio de janeiro: Imprensa Nacional, 1938, p.8.

${ }^{201}$ Ibid., p.98.
} 
pretensão racionalista de catalogar e enquadrar todas as variações de todos os seres animados e inanimados, a partir do seu lugar. O mote dessa ambição desmedida do controle da natureza pelo homem - branco - é oportuno para que sejam problematizadas as associações bastante comuns entre os contingentes populacionais de ameríndios e de africanos aos signos da selvageria e do instinto. O lugar comum dessas associações parece estar amparado pela ideia quase que unânime entre os pensadores brancos/europeus - e de seus descendentes nascidos na América - ${ }^{202}$ de que a razão, no século XVIII, e a civilização, no século XIX, afastariam o humano da natureza, ou de seu estado mais primitivo. ${ }^{203}$ Nesse sentido, os povos menos afeitos, porque outros, ao padrão comportamental estabelecido por aquela mesma branquitude, estariam mais suscetíveis aos seus impulsos mais originais e, mais próximos, portanto, no entender dos autointitulados racionais/civilizados, da espontaneidade típica do que seria o selvagem.

Essa construção retórica, presente tanto nos apologistas da civilização, entre eles Buffon e Montesquieu, quanto nos seus mais contundentes críticos, como Diderot $^{204}$ e Rousseau, ajudaria não apenas a atualizar aquela hierarquização dos povos já antecipada pelos renascentistas, como também a legitimar o discurso civilizacional orientador tanto da formação dos estados-nação ibero-americanos nas primeiras décadas do XIX, como das conquistas imperialistas que teriam lugar na segunda metade do mesmo século. ${ }^{205}$ Assim, as formulações de Buffon em defesa da capacidade de aperfeiçoamento dos povos, em tese inferiores, como as proposições de Montesquieu em relação à rigidez necessária aos regimes políticos

\footnotetext{
202 De acordo com Mary Louise Pratt, há um grande esforço das elites criollas ibero-americanas por construírem "uma base estética e ideológica enquanto americanos de raça branca." Ver: PRATT, Mary Louise. Imperial Eyes. Travel Writing and Transculturation. 2nd ed., London: Routledge, 2008 , p.300.

${ }^{203}$ Cabe pontuar que, ao final da década de 1920, Sigmund Freud retoma, pela perspectiva da psicanálise, essa pauta da civilização como cerceadora dos instintos e dos impulsos, oferecendo em O Mal-estar da Civilização uma análise provocativa a respeito da correspondência entre o superego do indivíduo e o processo civilizador como superego da sociedade. A esse respeito, ver: FREUD, Sigmund. O mal-estar na civilização. Penguin Editora, 2011.

204 Aqui pensamos, com Gumbrecht, em Diderot como autor marginal ao conceito normativo de Iluminismo, por desenvolver uma prosa antiteleológica e muito afeita ao contingencial, o que em muitos níveis ampliava a complexidade de seus textos para além das balizas estabelecidas pela racionalidade etnocêntrica de seus pares, entre os quais, aliás, sua presença era muito bem quista e, portanto, nada marginalizada. Supplement au Voyage des Bouganinville constitui precioso exemplar desta originalidade discursiva de Diderot em meio ao contexto da ilustração francesa. A esse respeito, ver: Denis Diderot. Supplement au Voyage des Bouganinville. Libro, 2007. Ver também: GUMBRECHT, Hans Ulrich. Prose of the world: Denis Diderot and the periphery of the Enlightenment.

${ }^{205}$ PRATT, Mary Louise.,op.cit.
} 
destinados a controlar as populações degeneradas dos países de climas quentes ou daqueles constituídos por grandiosas planícies, acabariam por contribuir para a mesma inferiorização dos contingentes não-brancos que, involuntariamente, as alegações de Rousseau sobre a virtuosidade do selvagem teriam contribuído.

As colocações do mesmo Rousseau em seu Discurso sobre a origem e os fundamentos da desigualdade entre os Homens se fazem pertinentes a esta altura, pois ilustram, nas entrelinhas, a persistência da convicção da distinção positiva do branco em relação ao outro, em um texto que, de antemão, se propunha a relativizar o eurocentrismo de seu contexto discursivo. Vejamos em que termos se podem verificar essas tensões:

(...) mas o homem selvagem, vivendo disperso entre os animais e vendo-se desde cedo na iminência de medir forças com eles, logo fez a comparação e, verificando que mais os ultrapassa em habilidade do que eles o sobrepujam pela força, aprende a não mais temê-los. Colocai um urso ou um lobo em disputa com um selvagem robusto, ágil, corajoso, como todos eles o são, armado de pedra e de um bom bastão, e vereis que o perigo será, no mínimo recíproco e que, depois de várias experiências semelhantes, as bestas ferozes, que não gostam de atacar-se mutuamente, com pouca vontade atacarão o homem, pois já verificaram ser tão feroz quanto elas. (...) Aí estão sem dúvida, os motivos pelos quais os negros e os selvagens dão tão pouca importância aos animais ferozes que possam encontrar nos bosques. ${ }^{206}$ (grifos meus)

Os negros e os selvagens aos quais Rousseau se refere são seus contemporâneos cronológicos, já que deles possui relatos de viajantes recémchegados de suas incursões, como o de François Correal, que descreve o comportamento dos caraíbas da Venezuela. ${ }^{207}$ No entanto, suas observações sugerem que, endossando a perspectiva etapista do Iluminismo, esses nativos americanos e africanos, estariam em etapa similar àquela na qual os europeus estiveram antes de desenvolverem-se e alcançarem o domínio das artes, das ciências e das letras. ${ }^{208}$ Ou seja, no esforço de elogiar as virtudes dos ditos selvagens - digo, negros e ameríndios, portanto, não-brancos - e de enaltecer sua robustez, agilidade

\footnotetext{
206 Jean Jacques Rousseau. Discurso sobre a origem e o fundamento da desigualdade entre os homens. Coleção Pensadores: $1^{\text {a }}$ Edição, São Paulo: Abril S.A. Cultural e Industrial, 1973. p. $245-$ 6.

${ }^{208}$ No que concerne ao etapismo como perspectiva norteadora do pensamento iluminista, há de se mencionar a obra The History of America de William Robertson. Publicada em 1777, a obra contribui para sedimentar as ideias já amplamente difundidas acerca das supostas fases do desenvolvimento das sociedades, oferecendo uma espécie de teoria dos quatro estágios pelos quais os povos passariam até alcançarem a etapa mais desenvolvida, representada pelo estabelecimento do comércio. Ver: ROBERTSON, William. The History of America. Whitestone, 1777.
} 
e coragem, definindo-os como alheios aos efeitos colaterais nocivos da civilização, Rousseau acabava por equipará-los às bestas ferozes, aproximando-os, assim das noções de instintividade e de irracionalidade e afiançando, quase que inconscientemente, o discurso hegemônico que procurava problematizar.

Ainda no que concerne à conveniente associação entre estado de natureza, primitivismo e povos ameríndios/africanos, cabe retornar à Viagem de von Spix e von Martius e com eles adentrar ao imaginário dos brancos/europeus - e aqui, sobretudo dos viajantes de origem germânica -, observando a maneira pela qual enxergavam esses seus semelhantes/dessemelhantes e demonstravam a compaixão típica dos que se consideram, mesmo à revelia de sua intenção, superiores. Ao narrarem que ainda nos seus primeiros dias no Rio de Janeiro foram convidados a participar de uma festa da padroeira dos negros, Nossa Senhora do Rosário, demonstram-se, diante dos filhos da África em festa, convencidos das benesses operadas pelo nobre trato da civilização europeia e, como numa ode à argumentação de Buffon acerca dos efeitos do exemplo na conversão dos inferiores, confessavam notar:

(...) de um lado, com regozijo, os traços de humanidade, que se desenvolvem no negro, e pouco e pouco, no convívio do branco; [e] por outro lado (...) lamentar que uma instituição tão bárbara e violadora dos direitos do homem, como é o tráfico de escravos, não cuide de dar a primeira escola para civilizar, mesmo no seu próprio país essa raça aviltada. ${ }^{209}$

Spix e Martius não se furtam, portanto, a reconhecer a já amplamente malograda experiência do tráfico, no entanto parecem considerá-lo uma instituição autônoma, gerida por negociantes pouco sensíveis ao que Buffon e também Blumenbach sinalizavam em relação à possibilidade de melhoramento daqueles contingentes de não-brancos que consideravam selvagens e/ou bárbaros. Os naturalistas bávaros narram essa mercantilização, sobretudo de cabindas $e$ benguelas, que ainda em África seriam marcados a fogo com um certo sinal nas costas ou na testa, mas não realizam qualquer crítica à escravidão propriamente dita, já que ela parece ser vista como a prática responsável por oferecer a oportunidade para que a dita raça aviltada se humanizasse através do convívio com a raça de proprietários já em outro patamar civilizatório. Por esse viés, a escravidão encarnaria, com algum efeito, o papel de distanciar os negros de seu estado

${ }^{209}$ K.F.P. von Martius. \& J.B. von Spix. Viagem pelo Brasil. $1^{\text {o }}$ vol. Rio de janeiro: Imprensa Nacional, 1938, p.112. 
primitivo - ou de seu estado de natureza -, aproximando-os, mesmo como serventes, dos modos de ser e fazer dos brancos civilizados. Afinal, como soava comum à época, o violento despojamento territorial e afetivo aos quais os povos escravizados eram expostos, seria, de acordo com a retórica da branquitude escravista - que Spix e Martius acabam por reiterar -, compensado na chegada dos africanos a esta borda oeste do Atlântico, uma vez que se adaptariam facilmente ao Rio de Janeiro, como ao Brasil em geral, em virtude "de seu temperamento leviano, [d]a semelhança do clima com o de sua pátria, e [d]a brandura com que são tratados no Brasil."210

Já as suas observações em relação aos povos americanos reproduzem, para além da já esperada lógica da inferiorização, a explícita animalização, sobretudo dos contingentes associados ao canibalismo. O comportamento, aliás, diretamente associado aos níveis mais extremos de barbárie, justamente pelo distanciamento que sugeria em relação à polidez dos costumes europeus, inspirava, para além da perplexidade dos ditos civilizados, curiosidade. Tamanha excentricidade, agora convertida em elemento da originalidade americana, precisava ser, no entender dos naturalistas - sobretudo daqueles filiados à tradição anatomista de Blumenbach ${ }^{211}$ mapeada, medida, e exposta, conforme relatavam com certo entusiasmo:

Quase não se veem indígenas americanos aqui. Eles evitam, quanto podem, a cidade (...) O primeiro indígena americano que avistamos aqui foi um menino da tribo antropófaga dos botocudos de Minas Gerais, ele se achava na casa do nosso amigo von Langsdorff. O antigo ministro de Estado português, Conde da Barca, havia pedido ao comandante do distrito dos índios em Minas Gerais um crânio de índio para o nosso celebre compatrício o conselheiro Blumenbach; como este último não teve oportunidade de achar à mão tal documento morto, despachou então ao conde dois botocudos vivos, que os seus soldados haviam prendido de surpresa; o sr. Von Langsdorff recebeu então um deles, ao qual em breve muito se afeiçoou e lhe serviu não somente como peça viva de gabinete, porém igualmente, como coletor de curiosidades naturais. ${ }^{212}$

Tal relato remete à recorrente prática de se montar Gabinetes de História Natural. Prática essa que, pelo menos desde o século XVII, obedecia à lógica $d a$ exposição das coisas em quadro e que pressupunha a observação como prérequisito à descrição. Assim os seres e as coisas eram colocados à disposição do

\footnotetext{
${ }^{210}$ K.F.P. von Martius. \& J.B. von Spix. Viagem pelo Brasil. $1^{\circ}$ vol. Rio de janeiro: Imprensa Nacional, 1938, p.113.

${ }^{211}$ Conforme desenvolvido no Capítulo 1 desta tese, Blumenbach, como anatomista e antropólogo, defendia que as distinções entre as raças deveriam ser averiguadas a partir da medição do crânio, do posicionamento das mandíbulas e do alinhamento das orelhas.

${ }^{212}$ K.F.P. von Martius. \& J.B. von Spix. Viagem pelo Brasil. $1^{\circ}$ vol. Rio de janeiro: Imprensa Nacional, 1938, p.95.
} 
olhar, como que zerados de significados e, portanto, aptos a serem descritos de acordo com o crivo do observador. ${ }^{213}$ De qualquer forma, se faz necessário destacar o etnocentrismo que atravessa esse relato sobre os botocudos, assim como a axiomática naturalização do aprisionamento e da escravização de nativos. Ocorre que a penetração das ideias no imaginário social dos que se reconheciam brancos e até dos não-brancos cooptados pela trama escravista - era tal, que tornava viável esse tipo de enunciado. De outro modo, a linguagem compartilhada ainda permitia, como que espelhando o fluxo espontâneo das ideias, que esse relato fosse publicado e circulasse com significativa receptividade entre eruditos e curiosos à revelia do que o aparato legal determinava. Na esteira da persistência dessa ampla e versátil retórica de inferiorização dos povos não-brancos, cabe reiterar que embora Spix e Martius tenham atravessado o Atlântico já informados por uma outra ordem discursiva que não aquela da condenação do clima e das paisagens dos lugares de altas temperaturas e, por isso mesmo, predispostos a reconhecer a riqueza e a singularidade da natureza destas afortunadas latitudes, ${ }^{214}$ ainda lhes fazia sentido operar na lógica do exotismo, quando o olhar se deslocava da paisagem para os seres mais ou menos humanos que ali figuravam.

A percepção pejorativa em relação aos habitantes desse Brasil de natureza exuberante não estava restrita ao olhar dos naturalistas bávaros. Em uma publicação francesa de 1830, intitulada Souvenires du Brésil, o mesmo tom é mobilizado para lamentar o fato de paisagem tão magnífica ser povoada por seres tão infelizes:

(...)logo surge a decepção quando se pisa em terra (refere-se ao Rio de Janeiro), tendo em vista que por toda parte há de se encontrar uma multidão de negros e mulatos. O semblante desses seres desafortunados, infelizes, seminus e brutalizados aflige dolorosamente o viajante europeu, acostumado como está à limpeza nos trajes e à polidez nas maneiras. ${ }^{215}$

Nessa espécie de compêndio da literatura de viagens, não é a escravidão a responsabilizada pelos modos brutalizados dos negros e mulatos, mas sim os caracteres supostamente inerentes a sua própria condição racial, como, aliás, alguns anos adiante, no mesmo sentido, sugeriria Francisco Sales de Torres-Homem, o letrado mulato integrante da tríade de autores da Nitheroy Revista Brasiliense. Tais

\footnotetext{
213 FOUCAULT, Michel. As palavras e as coisas: uma arqueologia das ciências humanas. São Paulo, Martins, 2000, p.179.

${ }^{214}$ K.F.P. von Martius. \& J.B. Spix. Viagem pelo Brasil. $1^{\circ}$ vol. Rio de janeiro: Imprensa Nacional, 1938, p.104.

${ }^{215}$ Souvenirs du Brésil, NAV, série 2, 46, nº 16 (1830), p.199-200.
} 
impressões relatadas pelos viajantes franceses, sobretudo as de autoria de Chateaubriand, Auguste de Saint-Hilaire e Ferdinand Denis ressoariam intensamente no que se delinearia como o Romantismo brasileiro, conforme ilustra o exemplo de Torres-Homem. ${ }^{216}$

A redefinição do olhar europeu sobre a paisagem e sobre a sua contígua manifestação humana - o selvagem americano - se materializava nas narrativas iconográficas e descritivas que esses viajantes oitocentistas publicavam. O Ensaio da década de 1820, no qual Chateaubriand narra sua viagem à América do Norte, difundia, por exemplo, uma percepção do nativo americano como uma possibilidade de redenção ao caos em que o mundo ocidental havia se transformado após os processos revolucionários desencadeados pela queda da Bastilha. ${ }^{217}$ No entender desse expoente do Romantismo francês, os nativos americanos representavam uma nova oportunidade, ou uma nova chance para que a humanidade recomeçasse sua marcha e, assim, se desenvolvesse mais virtuosamente, a partir daquelas características mais originais, ou mais instintivas da espécie humana, para as quais Rousseau já havia acenado positivamente.

$\mathrm{Na}$ esteira da configuração da episteme romântica francófona, é inevitável atestar que essa reordenação retórica articulada entre as décadas de 1820 e 1830 subverteu a lógica etnocêntrica da própria razão universal ao dialogar com a valoração das especificidades locais e ao reconhecer um índice positivo na diferença, ou no que se constituía alheio à sua própria imagem civilizacional. Quando, por exemplo, Ferdinand Denis apresentou, ainda em 1824, sua argumentação em defesa dos benefícios do clima, da exuberância da natureza e da virtuosidade dos povos americanos, ele enunciava uma outra, ou melhor, uma nova consciência intelectual, então menos pretenciosa em relação a sua centralidade e, por conseguinte, mais arguta em relação ao etnocentrismo que atravessava a tradição universalista com a qual interagia. Não que Scène de la nature sous les tropiques et de leur influence sur la poésie ${ }^{218}$ constituísse um marco do relativismo,

\footnotetext{
216 O texto no qual Torres-Homem discorre sobre suas impressões acerca da escravatura e da condição racial dos negros será analisado na última parte deste capítulo.

${ }^{217}$ Segundo, François Hartog, Chateaubriand abandonará essa sua posição otimista em relação aos selvagens já na década seguinte, quando se tornará incontestável a subjugação dos povos nativos americanos pelo projeto civilizacional europeu. HARTOG, François. Regimes de historicidade: presentismo e experiências do tempo. Belo Horizonte: Autêntica Editora, 2014.

${ }^{218}$ Ferdinand Denis. Scène de la nature sous les tropiques et de leur influence sur la poésie. Paris: Louis Janet, 1824. Disponível em: www.gallica.bnf.fr
} 
mas com esta obra Denis renovaria a abordagem sobre a América do Sul, apresentando como algo assertivo aquilo que comumente soava desabonador aos viajantes estrangeiros. Na percepção do romântico francês, se difundia a sensação de “(...) qu'il est aussi important les pensées des hommes que les production de leur territoire. On sent même que dans les idées primitives du sauvage, il y a um caractère de grandeur que étonne au milieu de notre ordre social." 219

Aliás, conforme Denis maturava suas pesquisas realizadas à época de suas viagens exploratórias pelos territórios sul-americanos e as desdobrava em uma série de publicações, ${ }^{220}$ mais contundentes se tornavam seus argumentos em favor de uma poesia genuinamente americana. ${ }^{221}$ Ele estava convicto de que a exuberância da natureza e o clima do Novo Mundo provocavam "influence directe sur les inspirations poétiques." 222 Isto é, na sua compreensão, se ao gênio do poeta era inerente a sensibilidade à opulência dos pássaros, dos oceanos e das palmeiras, nada mais óbvio do que haver uma literatura produzida por aqueles que testemunharam natureza tão exuberante. Importante notar que esse movimento de encorajar literaturas autênticas em jovens países, profundamente atrelados às suas matrizes metropolitanas, constituía um coerente desdobramento da retórica romântica que extrapolava, mas não negava, os limites da civilização europeia. É como se o Romantismo exercitasse a capacidade dos europeus de alargar seus horizontes para além das balizas fincadas pela razão ilustrada, recorrendo a estratégias da ordem do sensível e ocupando aquela brecha aberta por Rousseau ao problematizar os progressos civilizacionais.

\footnotetext{
219 “(...) que também são importantes os pensamentos dos homens que produzem (sic) em seu território. Nós sentimos realmente que nas ideias primitivas do selvagem existe um caráter de grandeza, que surpreende ao meio de nossa ordem social." (tradução livre) Ibidem, Prefácio, p.1.

${ }^{220}$ Ferdinand Denis (1798-1890) pretendia seguir a carreira diplomática, respeitando a tradição familiar de lealdade à Coroa, mas com a reordenação imposta pelos processos revolucionários franceses, opta, em 1816, por integrar uma expedição ao Brasil, onde permanece até 1819. Ao retornar à França, passa a desempenhar funções em bibliotecas, sendo a Bibliotèque Sainte Geneviève o espaço no qual trabalhou por mais de quarenta anos, inicialmente como conservador e posteriormente como administrador. Ao longo de sua atividade intelectual publicou grande número de obras relativas ao Brasil e à América do Sul, dentre as quais destacam-se: Le Brésil, ou, Histoire, moeurs, usages et coutumes des habitants de ce royaume (publicada em 1822, em parceria com Hippolyte Taunay); Scène de la nature sous les tropiques et de leur influence sur la poésie (1824); Resume de l'Histoire du Brésil, suivi du Resume de l'Histoire de la Guyane (1825); Histoire Geographique du Brésil (1833).

${ }^{221}$ A expressão é de Alfredo Bosi em História Concisa da Literatura Brasileira. Ver: BOSI, Alfredo. História Concisa da Literatura Brasileira. São Paulo: CULTRIX (37ª edição), 1994. p.98. ${ }^{222}$ Ferdinand Denis. Scène de la nature sous les tropiques et de leur influence sur la poésie. Paris: Louis Janet, 1824, Capítulo I, p.2. Disponível em: www.gallica.bnf.fr
} 
No entender de Denis, assim como no do autor romântico português Almeida Garret, ${ }^{223}$ a paisagem sul-americana e seus povos autóctones emanavam uma coloração sui generis e provocavam uma experiência sensorial única. De acordo com as observações do autor francófono, no Brasil por onde excursionou, “tout présente une admirable hamonie (...) qu'on pourrait appeller la patrie naturelle de 1'hommes." 224 Muito em função de toda essa exuberância da paisagem local, e de toda a associação entre esse espaço e a noção de pátria que compartilhavam, Denis considerava inadiável que os esforços de seus contemporâneos românticos do Brasil fossem, justamente, o de recuperar as obras literárias pretéritas convenientes a essa perspectiva da exaltação da autenticidade brasileira. Nesse sentido, a idealização rousseauniana da natureza e a mitificação do índio deveriam ser retroativamente identificadas naquilo que se havia produzido de literatura até então, afinal, natureza tão privilegiada não teria passado imune aos olhos sensíveis dos poetas pretéritos. Assim, sugeriam, conscientemente, que uma trajetória literária local fosse forjada retrospectivamente. Isto é, Denis e Garret, embora filiados a escolas ilustradas distintas, estavam convencidos da importância que a dimensão subjetiva da experiência humana adquiria à medida em que se apresentavam, embora ainda bastante dispersas, novas formas de pertencimento em um mundo que assistia à dissolução dos referenciais aristocráticos e à distensão das relações entre súditos e monarcas.

Com efeito, essa retórica romântica de valorização da natureza e do índio reconfigurava a retórica universalista de viés etnocêntrico, aliás, reiteradamente desqualificadora de manifestações alheias aos paradigmas civilizacionais europeus. ${ }^{225}$ Nessa esteira da legitimação da diferença, as impressões bastante correntes que relacionavam o Novo Mundo à excentricidade, atribuindo-lhe adjetivos pejorativos e associando-o à ideia de deterioração, perdiam então tônus à

\footnotetext{
223 João Baptista da Silva Leitão de Almeida Garret (1799-1854) integrou, ao lado de Alexandre Herculano, a primeira geração do Romantismo português. Seu poema Camões, publicado em 1825, é considerado um marco fundador do movimento em terras lusitanas. Cabe aqui, fazer menção ao estudo de Francisco Falcon sobre o iluminismo português, no qual chama a atenção para as especificidades do racionalismo ilustrado em terras lusófonas, Ver: FALCON, Francisco J. C. A época pombalina: política econômica e monarquia ilustrada. Rio de Janeiro: Editora Ática, 1982. 224 "Tudo apresenta uma harmonia admirável, que nós poderíamos chamar de pátria natural dos homens." (Tradução livre) Ferdinand Denis. Scène de la nature sous les tropiques et de leur influence sur la poésie. Paris: Louis Janet, 1824, Capítulo I, p.2. Disponível em: www.gallica.bnf.fr ${ }^{225}$ No que concerne às disputas discursivas entre o universalismo ilustrado e o nacionalismo romântico, ver: TODOROV, Tzvetan. Nós e os outros: a reflexão francesa sobre a diversidade humana. Rio de Janeiro: Jorge Zahar Ed., 1993.
} 
medida em que se fortalecia o reconhecimento de suas características como potências da ordem do particular, do específico, ou do que Denis considerava " $n$ 'a rien à leur comparer." ${ }^{226}$ Não obstante, em que pesassem as novas percepções a respeito das alteridades, os românticos franceses não conseguiam, ou não podiam, romper por completo com os paradigmas que os havia formado. ${ }^{227}$ Interagiam todos, portanto, com uma tradição racionalista atravessada por um universalismo que estabelecia uma sutil, mas reincidente padronização da realidade, implicando, assim, na produção de interpretações parciais acerca das alteridades, ou mesmo, na representação depreciativa do outro, sobretudo representado pelo fenótipo do nativo americano e do nativo africano. Esse universalismo, em grande parte etnocêntrico, - do qual descende, inclusive, o devir civilizatório europeu - se faria insistentemente presente e contribuiria para ainda fazer subsistir aquelas representações um tanto quanto estereotipadas da diversidade humana desta nossa porção americana lusófona. Isto porque, quem diferisse dos padrões estéticos europeus, parecia excêntrico a esses olhares educados na tradição artística neoclássica e orientados pelos parâmetros do racionalismo ilustrado.

Com algum efeito, toda a bildung ${ }^{228}$ dos letrados inseridos nesse contexto nos parece atravessada por uma quase inconsciente repulsa em relação à diversidade, que se manifesta, até involuntariamente, em ocasiões nas quais não há intenção explícita em afirmar a hegemonia do discurso da superioridade branca. A diluição dessas noções racialistas no amplo processo formativo dos homens de letras, de artes e de ciências dos séculos XVIII e XIX, nos parece expressar o profundo enraizamento dos paradigmas fisiológicos, psicológicos e estéticos a respeito de si e do outro. Nesse sentido, é importante notar que essa capilarização da vasta retórica racialista resistiria, inclusive, às transfigurações operadas pelo

\footnotetext{
226 "Não haver nada comparável” (Tradução livre) Ferdinand Denis. Scène de la nature sous les tropiques et de leur influence sur la poésie. Paris: Louis Janet, 1824, Capítulo I, p.2. Disponível em: www.gallica.bnf.fr.

${ }^{227}$ A respeito do caráter transitório da geração do Romantismo, ver: HARTOG, François. Regimes de historicidade: presentismo e experiências do tempo. Belo Horizonte: Autêntica Editora, 2014. Ver também: GUIMARÃES, Manoel Luiz Salgado. Entre amadorismo e profissionalismo: as tensões da prática histórica no século XIX. Topoi, Rio de Janeiro, dezembro 2002, pp.184-200.

${ }^{228} \mathrm{O}$ conceito de Bildung é muito próximo da ideia de formação. Segundo Antoine Berman, bildung possui indubitáveis conexões com a pedagogia e com as artes, sobretudo porque expressa o amplo processo formativo dos espíritos. Nesse mesmo sentido, Hans Gadamer considera "o conceito de Bildung (...), sem dúvida alguma, a ideia mais importante do século XVIII e é precisamente esse conceito que designa o elemento aglutinador das ciências do espírito do século XIX." Para maiores desdobramentos, ver: SUAREZ, Rosana. Nota sobre o conceito de Bildung (formação cultural). Kriterion, vol.46, n¹12, Belo Horizonte, Dezembro, 2015.
} 
labor interpretativo do próprio Romantismo. Isto é, mesmo com a representação positivada da paisagem e do nativo americano, prevaleceria, ainda, o entendimento subjacente de que esses povos e esses espaços integravam um patamar anterior ao europeu na escala civilizacional.

Interlocutor das obras de Chateaubriand e de Denis, confrade de alguns dos maiores nomes do Romantismo francês no Institut Historique de Paris, Gonçalves de Magalhães desenhou os moldes do Romantismo brasileiro conjugando essas referências ao seu conhecimento empírico sobre o Brasil. O Romantismo que se define a partir da Nitheroy Revista Brasiliense e da obra Suspiros Poéticos e Saudades parece de fato ressignificar a retórica do determinismo espacial amplamente difundida pelo saber setecentista. Sem deixar de reiterar a ingerência do clima na formação do caráter humano, esse romantismo tropical gestado em Paris se apropria de uma percepção, que se constitui a partir de Rousseau e se fortalece com os narradores-viajantes ${ }^{229}$ do XIX, para inverter a interpretação negativa acerca dos países tropicais, sobretudo os do hemisfério Sul. ${ }^{230}$

De todo modo, tanto os apontamentos dos naturalistas bávaros, quanto as andanças tropicais de Ferdinand Denis, como a chegada da Missão Artística Francesa ao Rio de Janeiro, integrariam esse movimento de duas faces: a desbravadora de uma natureza observada em sua exuberância, natureza essa que incluía o índio original - aquele do passado - como encarnação da beleza e da virtude; e, por outro lado, a face legitimadora da noção de que os negros, assim como os índios do presente estariam inclinados a um primitivismo degenerado. Todo o cabedal narrativo e iconográfico criado por esses viajantes contribuiu, não apenas para ressignificar o olhar europeu em relação ao Sul e seus habitantes originais, como também para reiterar uma série de estereótipos herdados do contexto discursivo dos Iluminismos. Com efeito, esses escritos dos viajantes narradores do XIX, constituíram expressões de um tempo em que a interpretação do Brasil cabia majoritariamente ao olhar estrangeiro, o que, num movimento dialético, ao servir como uma espécie de mostruário das especificidades, acabou

\footnotetext{
${ }^{229}$ SÜSSEKIND, Flora. O Brasil não é longe daqui. O narrador, a viagem. São Paulo: Companhia das letras, 1990.

${ }^{230}$ Lorelai Kury constrói a hipótese central de seu artigo intitulado No calor da pátria a partir do argumento de que a retórica indianista de Gonçalves de Magalhães se ampara, mas também ressignifica as teorias deterministas desenvolvidas por Montesquieu e por Buffon. Ver: KURY, Lorelai Brilhante. No calor da pátria. Revista USP, São Paulo, n72, p.80-89, dez. - fev. 2006-2007.
} 
por catapultar a percepção de que toda essa originalidade só poderia ser apreendida integralmente por autores pátrios. Na esteira dessas narrativas de viagem, a timidez dos autores árcades em valorizar a cotia à lebre ou a palmeira ao pinheiro, passou a ceder lugar ao que tomaria corpo com o Romantismo de Gonçalves de Magalhães e Gonçalves Dias. ${ }^{231} \mathrm{O}$ Brasil passou, então, a se explicar por si próprio, por suas especificidades. Um Brasil que, não por acaso, a partir de 1820, já transitava do pertencimento português à construção de uma outra ordem identitária. Reordenação essa que concorreria para que os letrados da geração de 1830 pudessem agir em nome da reinvenção do que julgavam indispensável.

\subsection{Da urgência da originalidade}

Bem antes de pretender publicar a Nitheroy, ainda em 1834, Magalhães, Torres-Homem e Porto-Alegre tiveram a oportunidade de explanar em sessão do Institut Historique de Paris suas ideias em defesa do resgate de uma suposta História da Literatura Brasileira. Tal explanação daria origem ao Resumé de l'histoire de la littérature, des sciences et des arts au Brésil, logo publicado pelo Journal de l'Institut Historique de Paris. ${ }^{232}$ Já na ocasião dessa exposição acerca de uma suposta identidade literária brasileira - inclusive anterior aos trâmites da independência -, a tríade de letrados brasileiros já antecipava a sua adesão consciente ao modus operandi do Romantismo francês, negando a visceral ascendência literária lusitana, para afirmar o caráter transcendental de uma genuína literatura do Brasil, pois “com a expiração do domínio Português desenvolveramse as ideias." ${ }^{233}$ Iniciavam-se ali no Institut, portanto, as articulações no sentido de conformar as dispersas contribuições literárias de um passado colonial em uma trajetória literária nacional, tornando-a conveniente não apenas aos desejos mais imediatos de emancipação intelectual, como também às projeções de uma nacionalidade consistente.

\footnotetext{
${ }^{231}$ Citamos aqui apenas dois dos primeiros indianistas de vulto que, em prosa e verso, dedicaram-se a tecer uma estética original para o Brasil.

232 Ver Ledo Ivo (apresentador). "Discurso sobre a história da literatura no Brasil"/ Domingos José Gonçalves de Magalhães, Rio de Janeiro, Fundação Casa de Rui Barbosa, 1994.

${ }^{233}$ Domingos José Gonçalves de Magalhães. Ensaio sobre a História da Literatura do Brasil. Nitheroy Revista Brasiliense. Tomo I, vol.1, Dauvin et Fontaine Libraires: Paris, 1836, p.149.
} 
Ao que parece, essa tomada de consciência guardaria relação, justamente, com a filiação de Magalhães, Torres Homem e Araújo Porto-Alegre ao Institut Historique. Fundado em dezembro de 1833, por Eugéne Garay de Monglave, ${ }^{234} \mathrm{o}$ Institut constituiu expressão do espírito de transitoriedade da época. Conciliando a tradição da erudição enciclopedista setecentista às demandas coetâneas de um historicismo romântico impregnado de pragmatismo político, a confraria compartilhava o propósito de alimentar a dimensão sensível da estética nacional. ${ }^{235}$ O uso político do passado constituiria o ethos do Institut. A busca por uma origem comum aos povos franceses e a premência por um repertório de experiências que pudesse servir ao tempo presente e pavimentar o futuro pautavam as diretrizes sob as quais estavam filiados não apenas a tríade de futuros redatores da Nitheroy, como também alguns outros letrados de vulto da Corte do Brasil, como José Feliciano Fernandes Pinheiro, Januário da Cunha Barbosa, Evaristo da Veiga, Francisco Freire Alemão, entre outros quarenta compatriotas. ${ }^{236}$ Dos citados, com a exceção de Evaristo da Veiga, todos integrariam, a partir de 1838, o Instituto Histórico e Geográfico Brasileiro, muito similar, aliás, no propósito e na dinâmica de atividades à instituição parisiense. A versão brasileira deste academicismo utilitário, compartilhava, pois, o objetivo primário de reunir memórias e documentos dispersos por todo território do Império do Brasil, para que, na sequência, a História Pátria pudesse ser narrada e pudesse, assim, produzir uma sensação de unidade

\footnotetext{
${ }^{234}$ Eugene Garay de Monglave exerceu a função de Oficial do Estado Maior francês, ocupação que lhe destinou a incursionar por Espanha, Portugal e Brasil, onde permaneceu entre 1820 e 1823. Muito próximo de D. Pedro I, dedicou a tradução francesa de $O$ Caramuru (1825) à D. Maria da Glória, filha do Imperador e futura rainha de Portugal. Além de fundador do Institut Historique, ocupou a cadeira de Secretário Perpétuo, de onde coordenava as atividades e as afiliações à instituição.

${ }^{235} \mathrm{O}$ surgimento de Institutos Históricos foi um fenômeno comum não apenas a países europeus dedicados a ensejar uma identificação nacional através de uma História Pátria, como também aos jovens países ibero-americanos envolvidos na dinâmica de promoverem-se enquanto Estados-nação. O próprio Instituto Histórico e Geográfico do Brasil seria fundado com este propósito em 1838 e a ele pertenceriam, inclusive, os três redatores da Revista Nitheroy. A esse respeito, ver: GUIMARÃES, Manoel Luiz Salgado. Nação e civilização nos trópicos: o Instituto Histórico e Geográfico Brasileiro e o projeto de uma História Nacional. Revista Estudos Históricos, vol.1, nº1, 1988, p.5-27.

236 A título de complementariedade, cabe registrar que José Feliciano Fernandes Pinheiro, o Visconde de São Leopoldo, seria o primeiro Presidente do IHGB, enquanto Januário da Cunha Barbosa, para além de fundador do Instituto, ocuparia também o decisivo cargo de Secretário Perpétuo. Já Freire Alemão, médico do Imperador D.Pedro II, como sócio do IHGB, atuou em comissões avaliativas e assinou pareceres relevantes como o que recomendou a dissertação "Como se deve escrever a História do Brasil”, de von Martius, à premiação. A respeito da galeria de sócios componentes do Institut Historique de Paris, ver: CARRARO, Elaine Cristina. O Brasil como tema no Instituto Histórico de Paris. Revista do Instituto Histórico de Sergipe, nº47, 2017.
} 
política que transcendesse a própria invenção do Brasil como país. Fundado apenas dois anos depois da publicação da Revista Nitheroy, o IHGB se encarregaria de acolher as demandas desta porção lusófona do Atlântico por uma História, uma Geografia e uma Etnografia de contornos nacionais, que desse conta de alavancar aquele desejo por uma emancipação intelectual reivindicada já desde o Parnaso e devidamente enfatizada pela mesma Nitheroy. ${ }^{237}$

Mas antes de circular pelo IHGB, Magalhães, Torres Homem e PortoAlegre frequentaram, como já antecipamos, o mesmo Institut Historique onde nomes como os de Jules Michelet, Ferdinand Denis e Chateaubriand transitavam. Aos jovens brasileiros, essa interlocução, sobretudo com Chateaubriand e Ferdinand Denis, em Paris, constituiria via de acesso ao enfrentamento do que consideravam ser a fragilidade identitária do Brasil inconcluso. Lá, experimentavam um novo tempo aberto pelas grandes revoluções do XVIII e trabalhavam em prol de uma nova concepção de História - agora singular, nacional e dotada de arcabouço metodológico. ${ }^{238}$ No entanto, pareciam não conseguir abrir mão por completo da tradição Magistra que os havia constituído como homens de letras e, nesse movimento, iam se familiarizando com os novos imperativos de um tempo em que os exemplos do passado já pouco serviam ao presente, cada vez mais inédito. ${ }^{239}$

Essa geração de letrados presente nos primeiros anos de atividade do Institut Historique, bem como, mais adiante, nos primórdios do IHGB, partilhava o entendimento de que os novos usos do passado faziam com que as experiências pretéritas parecessem etapas de um desenvolvimento linear e progressivo, no qual o presente era sempre melhor que o passado e o futuro melhor que o presente. Assim, os elementos pretéritos dispersos em relatos e memórias históricas deixavam de fazer sentido isoladamente e passavam a ser alinhados como partes de um todo maior, como engrenagens de um processo, como elementos constitutivos de uma grande narrativa chamada, pretensamente, pelos sujeitos contemporâneos,

\footnotetext{
${ }^{237}$ Cabe sempre salientar que a essa altura não estava ainda consolidada a divisão / disciplinarização dos campos do saber, por isso quando no Parnaso e na Nitheroy o devir da emancipação literária se apresenta, ele comporta não apenas a poesia, mas também as memórias históricas, a cartografia, os relatos etnográficos, as análises econômicas, as artes e a filosofia.

${ }^{238}$ ARAÚJO, Ricardo Benzaquen de. História e narrativa. In: MATTOS, Ilmar Rohloff de. (org.) Ler \& Escrever para contar: documentação, historiografia. Rio de janeiro, Access Editora, 1998. Pp. 221-258.

${ }^{239}$ KOSELLECK, Reinhart. Futuro Passado: contribuição à semântica dos tempos históricos. Rio de Janeiro: Contraponto: Ed. PUC-Rio, 2006.
} 
de História Universal. Aos Institutos Históricos, em profusão na década de 1830, coube, portanto, a função de operar o passado em acordo com os critérios e métodos de um ofício que se pretendia científico, acomodando os eventos pretéritos na narrativa nacional que trabalhavam para alinhavar. Não obstante, a referência aos Antigos, o uso da linguagem rebuscada, o elogio da erudição e a permanência de práticas que remontavam às academias seiscentistas e setecentistas faziam desses novos espaços de produção do conhecimento, espaços de coexistência de dois modelos, espaços comprometidos com a nova ordem, mas informados pelas maneiras de um mundo que, aos poucos, deixava de existir. ${ }^{240}$

Uma das prerrogativas inerentes ao pragmatismo que definiu esse historicismo romântico foi a ampliação do alcance de suas publicações, sobretudo porque suas obras possuíam uma forma mais palatável ao grande público, oferecendo narrativas que encadeavam princípio, meio e fim e ofereciam um sentido. Magalhães, no Ensaio sobre a História da Literatura do Brasil, publicado na Nitheroy, já parecia atento, tanto ao movimento de tornar os textos mais acessíveis, quanto a essa nova maneira de lidar com o passado:

(...) o nosso fim não é traçar a biografia cronológica dos Autores Brasileiros, mas sim a História da Literatura do Brasil, que toda história, como todo drama, supõe lugar da cena, atores, paixões, um fato progressivo, que se desenvolve, que tem sua razão, como tem uma causa, e um fim. Sem estas condições nem há história, nem drama. ${ }^{241}$

Então, se caíam em desuso as histórias cronológicas - compostas por eventos elencados pela ordem temporal na qual haviam ocorrido -, ganhavam espaço as histórias filosóficas, marcadamente orientadas por estratégias discursivas, que, por sua vez, redimensionavam as fronteiras, há muito nuançadas, entre o factual e o ficcional. ${ }^{242}$ Todavia, apesar do compromisso cada vez maior da escrita da história com a objetividade e com critérios metodológicos, a forma narrativa,

\footnotetext{
${ }^{240}$ De acordo com a análise de François Hartog sobre a vida e obra de Chateaubriand, a atuação intelectual dessa geração de românticos foi marcada pela transitoriedade entre dois regimes de historicidade distintos: o antigo e o moderno. A eles corresponderiam os distintos modos de se operar o passado: a Histoire e a Geschichte, respectivamente mobilizadoras dos usos magistra e progressista dos eventos pretéritos. A esse respeito ver: HARTOG, François. Regimes de historicidade: presentismo e experiências do tempo. Belo Horizonte: Autêntica Editora, 2014. Ver também: KOSELLECK, Reinhart. Futuro Passado: contribuição à semântica dos tempos históricos. Rio de Janeiro: Contraponto: Ed. PUC-Rio, 2006. E ainda: GUIMARÃES, Manoel Luiz Salgado. Entre amadorismo e profissionalismo: as tensões da prática histórica no século XIX. Topoi, Rio de Janeiro, dezembro 2002, pp.184-200.

${ }^{241}$ Domingos José Gonçalves de Magalhães. Ensaio sobre a História da Literatura do Brasil. Nitheroy Revista Brasiliense. Tomo I, vol.1, Dauvin et Fontaine Libraires: Paris, 1836. p.135. ${ }^{242}$ LIMA, Luiz Costa. História. Ficção. Literatura. São Paulo: Companhia das Letras, 2006.
} 
tradicionalmente associada ao espectro ficcional, passava a se apresentar como uma importante aliada do universo factual, na tarefa de forjar o enredo no qual o EstadoNação se manifestava, atendendo à prerrogativa teleológica, então em alta. ${ }^{243}$ Assim, a experiência historicista compartilhada por esses letrados, os colocava diante do axioma da inevitabilidade do surgimento dos Estados nacionais, como se apenas esta configuração - a do Estado-Nação - estivesse no destino das sociedades ocidentais. Era como se estivesse determinado, no caso do Brasil, que desde os tempos das primeiras incursões lusitanas, essas terras americanas estivessem fadadas a se tornar o Império que se tornou no século XIX.

Operavam naquele tempo presente, portanto, esforços no sentido de uma conscientização do passado literário da América portuguesa como um passado literário brasileiro. Aliás, a apologia que faziam em torno de uma espécie de nacionalização retroativa das peças literárias de um fragmentado passado colonial acompanhava a tendência epistemológica ocidental - muito influenciada pela fenomenologia de Hegel ${ }^{244}$ a reconhecer o tempo como agente modificador de todos os fenômenos humanos. Daí decorreria, aliás, boa parte da inclinação do pensamento ocidental oitocentista à temporalização, ou ao ímpeto por situar no tempo toda a ação humana no mundo. Movimento que, de alguma maneira, já se antecipava nos recorrentes esforços ilustrados por interpretar historicamente a natureza, ou por temporalizar a velha e respeitável história natural. ${ }^{245}$ Fim para o qual, conforme já apontamos, contribuíram toda uma série de pensadores setecentistas, responsáveis por ressignificar o mundo das coisas e dos seres. ${ }^{246}$ No alinhavar das descrições oferecidas pelos naturalistas, foi se produzindo o entendimento, sobretudo a partir da publicação da Histoire Naturelle de Buffon, de que os avanços da humanidade refletiam uma marcha de melhoramento dos seres no tempo. Perspectiva que, com algum efeito, acabaria por corroborar

\footnotetext{
${ }^{243}$ De acordo com as reflexões de Ricardo Benzaquen a respeito das fronteiras da História, importa pensar a narrativa historiográfica como a dimensão literária do trabalho historiográfico, o que de modo algum, anula ou compromete as demais dimensões, sobretudo aquela relativa a sua aporia maior: o que de fato aconteceu. A esse respeito ver: ARAÚJO, Ricardo Benzaquen de. História e narrativa. In: MATTOS, Ilmar Rohloff de. (org.) Ler \& Escrever para contar: documentação, historiografia. Rio de janeiro, Access Editora, 1998. Pp. 221-258.

${ }^{244}$ Ibid.

${ }^{245}$ KOSELLECK, Reinhart. Estratos do tempo: estudos sobre história. $1^{\text {a }}$ Edição, Rio de janeiro: Contraponto: PUC-Rio, 2014, p.10.

${ }^{246}$ De acordo com Koselleck, Kant e Buffon desempenharam um certo protagonismo em explicar racionalmente o mundo da natureza, desde a Criação aos seus dias. A esse respeito ver: KOSELLECK, Reinhart. Op.cit., p.10.
} 
racionalmente, conforme temos afirmado, toda uma tradição retórica de hierarquização dos povos.

De qualquer modo, embora houvesse em franca coexistência outros modos de enxergar a experiência humana no mundo, o historicismo hegeliano acabaria por se tornar hegemônico nas enunciações do pensamento ocidental. Embora um Diderot fosse capaz de se fazer popular publicando obras alheias à expectativa teleológica e, portanto, indiferentes à lógica da narrativa linear e otimista, ${ }^{247}$ o modo historicista de interpretar o mundo ganharia cada vez mais adeptos à medida em que parecia se tornar a ferramenta cada vez mais apropriada para dar conta de explicar uma realidade exposta a profundas e inéditas transformações, como aquelas colocadas pela Revolução Americana, pela Revolução Francesa e pela Revolução do Haiti. Historicismo esse que inculcava o entendimento de que os sacrifícios e desconstruções do presente se justificavam frente à superação do passado em nome de um porvir sempre mais positivo. À tal inclinação à temporalização corresponderiam as aspirações do chamado Grupo de Paris por encadear autores e movimentos literários da lusofonia meridional, de modo a produzir uma História da Literatura do Brasil. Nesse sentido, a narrativa historicizante que pretendiam alavancar atendia, para além das demandas daquele tempo presente por uma ascendência literária, às projeções em relação a um futuro de coesão nacional. Consideramos tal convocação à formulação de uma literatura pátria, como um dos exponenciais episódios reais aos quais Koselleck se refere quando discute a capacidade que algumas circunstâncias possuem de dar a ver as encruzilhadas do tempo, na qual "o passado e o futuro se entrelaçam na presencialidade da experiência e da expectativa." ${ }^{248}$ O Ensaio sobre a História da Literatura do Brasil, comporta , em todo o seu percurso, esse jogo no qual o presente exerce a função de árbitro do passado e do futuro, reconstituindo linear e homogeneamente, com vistas a um futuro de unidade, um passado pulverizado em mesquinhos e esparsos documentos. ${ }^{249}$ Do trecho a seguir, emana, inclusive, a intenção de fazer retroagir a noção de Estado do Brasil aos tempos da chegada dos

247 GUMBRECHT, Hans Ulrich. Prose of the world: Denis Diderot and the periphery of the Enlightenment.

${ }^{248}$ KOSELLECK, Reinhart. Estratos do tempo: estudos sobre história. $1^{\text {a }}$ Edição, Rio de janeiro: Contraponto: PUC-Rio, 2014, p. 307.

249 Domingos José Gonçalves de Magalhães. Ensaio sobre a História da Literatura do Brasil.Nitheroy Revista Brasiliense. Tomo I, vol.1, Dauvin et Fontaine Libraires: Paris, 1836, p.136. 
europeus por esses territórios da América do Sul, de modo que soasse natural uma ideia transcendente de unidade pátria, em verdade gestada há pouco mais de uma década. Parecia, portanto, ao Gonçalves de Magalhaes de 1836 ser:

(...) mister remontarmo-nos ao estado do Brasil de pois [sic] de seu descobrimento, d'ahi pedindo conta à história, e à tradição viva dos homens de como se passaram as cousas [sic], seguindo a marcha do desenvolvimento intelectual, e pesquisando o espírito que a presidia, poderemos livremente mostrar, não acabado, mas ao menos verdadeiro quadro histórico da nossa Literatura." ${ }^{250}$

Curiosamente, o trecho supracitado do Ensaio recorre à literatura produzida durante o período colonial na intenção de transformar suas manifestações líricas em exemplares de uma espécie de protonacionalismo literário. ${ }^{251} \mathrm{Se}$, por um lado, tal postura pode soar incongruente em relação às acirradas críticas que a própria Nitheroy desferia contra o projeto colonizador português, avaliado como arcaico e, portanto, como um legado a ser superado, por outro, ela constitui uma via de incorporação de um recorte desse passado, pois, embora maculado pelas privações impostas pela censura intelectual e pelo estigma da escravidão, ele se fazia necessário naquela encruzilhada do tempo na qual o presente carecia de uma trajetória pretérita para ser capaz de inventar um futuro.

Nessa esteira, Magalhães invoca a noção de pátria para lidar com a noção de unidade política que permeia seu tempo presente, sem fazer qualquer menção ao Brasil como nação. Seu Ensaio, enquanto um dos atos de fala mais definidores de seu tempo, ${ }^{252}$ testemunha, muito claramente, a ressignificação da ideia de pátria diante das irreversíveis modificações desencadeadas pelas ocupações napoleônicas e o seu impacto sobre a própria trajetória da Literatura brasileira. Os editores da Nitheroy invocam a pátria em um sentido muito próximo ao de nação, pois, na medida em que conciliam a ideia de pátria como lugar à demanda pela coesão,

${ }^{250}$ Domingos José Gonçalves de Magalhães. Ensaio sobre a História da Literatura do Brasil, Nitheroy Revista Brasiliense. Tomo I, vol.1, Dauvin et Fontaine Libraires: Paris, 1836, p.135.

${ }^{251}$ A ideia de um protonacionalismo é trabalhada por Marco Antônio Pamplona em: PAMPLONA, Marco A. Comentarios sobre las independências y la formacion de estados-naciones em IberoAmerica: um abordaje comparado entre la America portuguesa y la America hispânica. In: GONZALEZ BERNALDO, Pilar (ed.): Independencias Iberoamericanas: nuevos problemas e aproximaciones. 2015, pp. 87-103.

${ }^{252}$ De acordo com Pocock, os atos de fala constituem ação de um sujeito histórico que verbaliza suas demandas dentro do escopo linguístico que lhe é acessível. Escopo esse recorrentemente alterado por enunciados inovadores - atos de fala - que podem representar verdadeiras guinadas lance - para o contexto linguístico em questão. A esse respeito, ver: POCOCK, J.G.A. Linguagens do ideário político. São Paulo: EDUSP, 2003. 
atualizam o seu sentido, enunciando o território como condicionante da unidade. Nas palavras de Magalhães:

No século XIX com as mudanças, e reformas políticas, que tem o Brasil experimentado, nova face literária [se] apresenta. Uma só ideia absorve todos os pensamentos, uma nova ideia até ali desconhecida, é a ideia da Pátria; ela domina tudo, tudo se faz por ela, ou em seu nome. Independência, Liberdade, instituições sociais, reformas, política enfim, tais são os objetos que atraem a atenção de todos, e os únicos, que ao povo interessam. ${ }^{253}$ (grifos meus)

Os usos que faz dos termos pátria e povo testemunham o amplo movimento singularizador da modernidade oitocentista, em meio ao qual o historicismo romântico atuou, com sua verve didática, na conversão das consciências, contribuindo para persuadir os povos integrantes de um mesmo Estado de que constituíam um único povo, assim como convencendo as múltiplas pátrias regionais de que eram apenas partes integrantes de uma única pátria, aquela maior e indivisível, correspondente aos limites territoriais do Estado. ${ }^{254}$ Não seria casual, portanto, a ambição dos Institutos Históricos por escrever a História Pátria, assim como não seria inoportuna a predileção desses espaços pelos gêneros biográfico e romanesco, como gêneros acessórios dessa grande narrativa da História una e disciplinar- com H maiúsculo. Afinal, a biografia e o romance serviam também ao propósito das construções narrativas lineares e teleológicas, porque capazes de espraiar o enredo da unidade pátria e de inventar um passado que justificasse o presente. ${ }^{255}$ No que concernia à elaboração discursiva de um passado intencionalmente colocado a serviço do presente, bem como do futuro, Gonçalves de Magalhães alertava:

(...) tudo o que puder concorrer para o esclarecimento da história geral dos progressos da humanidade merecer deve nossa consideração. Jamais uma Nação poderá prever o seu futuro, quando ela não conhece o que ela é, comparativamente com o que foi. Estudar o passado é ver melhor o presente, é saber como se deve marchar. (... $)^{256}$

Nesse sentido, a todo o legado hegeliano da categorização do tempo corresponderam não apenas a escritura de uma história - aquela História da política

\footnotetext{
253 Domingos José Gonçalves de Magalhães. Ensaio sobre a História da Literatura do Brasil, Nitheroy Revista Brasiliense. Tomo I, vol.1, Dauvin et Fontaine Libraires: Paris, 1836. p.152.

${ }^{254}$ PAMPLONA, Marco A. Pátria - Brasil. In: SEBÁSTIAN, Javier Fernandez (Dir.). Dicionario Politico y social del mundo ibero-americano. Tomo 8, Centro de Estudos Politicos y Constitucionales: Madrid, 2014.

${ }^{255}$ LORIGA, Sabina. O pequeno X: da biografia à história. Belo Horizonte: Autêntica Editora, 2011.

${ }^{256}$ Domingos José Gonçalves de Magalhães., op.cit., p.145.
} 
e da boa sociedade, como também a História da Literatura - determinada pelas balizas espaciais e temporais do Estado, como também a popularização de biografias e romances determinados a situar na trajetória supostamente nacional os feitos reais e míticos. Transitando pelas fronteiras borradas do factual e do ficcional, a biografia e o romance oitocentista foram colocados, assim como a história, a serviço da legitimação dos Estados nacionais. Aliás, talvez o sucesso editorial do gênero biográfico se justifique mesmo pela conveniência de sua condição apriorística: estar situado no cruzamento entre fato e subjetividade. Costurando circunstâncias reais e alinhavando um devir, a biografia ultrapassava os limites do relato e avançava, pois, na direção de uma narrativa acessível, dotada da potência de explorar as relações entre o indivíduo em foco e a superfície social a qual pertencia. Em um esforço por preencher a galeria de heróis nacionais, trajetórias de vida cirurgicamente selecionadas, tinham suas eventuais fissuras pessoais silenciadas e seus feitos públicos -que fossem convenientes- exaltados, assim se transformando em vidas exemplares, ou como não à toa o IHGB categorizou, como biografias de brasileiros ilustres. ${ }^{257} \mathrm{O}$ romance, por sua vez, também servia a uma certa popularização do fazer literário, ${ }^{258}$ mas não só porque oferecia uma narrativa inteligível, mas sobretudo porque operava com a simultaneidade das ações, narrando as personagens a partir de um lugar comum de pertencimento. De todo modo, tanto a narrativa histórica - nos padrões sinalizados por Magalhães -, quanto os dicionários biográficos e os romances nativistas em franca difusão na transição entre as décadas de 1830 e 1840 serviriam à propagação da ideia de que todo o restrito escopo de cidadãos do Império do Brasil pertencia a uma mesma pátria, possuía uma mesma origem, se identificava com os mesmos heróis, compartilhava a mesma memória e o mesmo horizonte.

Ademais, é bastante provável que a atuação de Magalhães, Torres Homem e Porto-Alegre no Institut tenha interferido tanto no discernimento que possuíam acerca das fragilidades do Brasil como unidade política, quanto na imagem, em grande medida estereotipada, que os letrados franceses faziam do Brasil. O convite

\footnotetext{
257 OLIVEIRA, M. da Glória de. Escrever vidas, narrar a história. A biografia como problema historiográfico no Brasil oitocentista. 1a. ed. Rio de Janeiro: FGV Editora/ EDUR/ ANPUH-Rio, 2011.

${ }^{258}$ De acordo com Wayne Both, a construção narrativa romanesca característica da modernidade oitocentista tornava a experiência do leitor mediano mais confortável se comparada à experiência com a poesia. Ver: BOOTH, Wayne. The rethoric of fiction. Chicago: University Chicago Press, 1982 , p. 160 .
} 
de Monglave para que tantos brasileiros integrassem o Institut certamente refletia interesse francófono em selar, institucionalmente, a parceria com autores da lusofonia tropical, assim construindo pontes entre a tradição interpretativa francesa que se reconfigurava e os representantes de um pensamento que começava a galgar a sua autonomia pós-colonial. Interesse esse que parecia, inclusive, corresponder à ambiciosa estratégia diplomática francesa por contrabalançar a predominância britânica na seara econômica do Brasil independente com a presença e a referência francesa em tudo o que fosse concernente às artes, às letras e às ciências. ${ }^{259}$ Nesse sentido, uma via de mão dupla se estabelecia: ao mesmo tempo em que a atuação dos letrados brasileiros em Paris colaborava com as intenções de um certo expansionismo civilizacional francês, a performance deles se beneficiava de uma abordagem romântica capaz de converter elementos comuns da fauna, da flora e dos povos em elementos potencializadores do específico, do local, do brasileiro.

Se colocava, então, a tensão entre a medida da inspiração e a da invenção, ou, em outras palavras, o quanto o movimento emancipador da intelectualidade brasileira deveria estar ancorado na originalidade literária e no reconhecimento e exaltação da cor local. De acordo com o manifesto de Gonçalves de Magalhães, ${ }^{260}$ o exercício literário que precisavam inaugurar deveria se livrar do peso colonial que por séculos lhes secundarizou em relação à metrópole, alavancando uma literatura capaz de enaltecer o que era próprio do Brasil, afinal, “em Poesia requer-se mais que tudo invenção, gênio, e novidade; (...) [pois] o que dá realce, e nomeada a alguns dos nossos Poetas é (...) sim outro gênero de belezas naturais, não colhidas nos livros, mas que só a Pátria lhes inspirará.” 261

A apreensão ficcional da realidade, operada em grande medida pelas artes e pela literatura, deveria passar a trabalhar, portanto, na chave da construção

\footnotetext{
${ }^{259}$ De acordo com Wilma Peres Costa, derivaram desta estratégia diplomática as várias missões artísticas e naturalistas que aportaram no Brasil a partir de 1816. Não apenas Missões da França, como também da Áustria, da Rússia e da Prússia - tríade pertencente à Santa Aliança- eram convidadas e recebidas em solo lusoamericano pelas Corte de D. João. A esse respeito, ver: COSTA, Wilma Peres. Viajantes europeus e o escrever da nação brasileira. In: DOYLE, Don H. \& PAMPLONA, Marco A. Nacionalismo no Novo Mundo. Editora Record: RJ e SP, 2008, p.306.

${ }^{260}$ Referimo-nos aqui ao Ensaio sobre a História da Literatura do Brasil, em sua dimensão convocatória dos letrados do Brasil à emancipação do pensamento. Domingos José Gonçalves de Magalhães. Ensaio sobre a História da Literatura do Brasil. In: Nitheroy Revista Brasiliense: Sciencias, Letras e Artes. Tomo I. Dauvin et Fontaine Libraires: Paris, 1836.

${ }^{261}$ Ibid., p.147.
} 
imagética do que se definia como essência pictórica da pátria. ${ }^{262}$ A propósito, uma ideia de pátria brasileira pouco precisa à época do ato de fala de Gonçalves de Magalhães, tendo em vista as potentes manifestações regionais contrárias à centralização imperial. Disputas essas que, na seara da formação das subjetividades, seriam, aliás, consideravelmente pacificadas pelo movimento romântico que Magalhães e seus pares da Nitheroy iniciavam ali, em $1836 .{ }^{263}$

No entanto, é preciso considerar o quão castrador ou delimitador das subjetividades foi o Romantismo em sua empreitada de fazer da literatura, mas não só dela, instrumento escultor da identidade nacional, ${ }^{264}$ restringindo toda a sua potência criativa aos temas correlatos à ideia de Brasil que procuravam emplacar, fosse através da exaltação da beleza das palmeiras e dos sabiás ou das virtudes dos índios. Machado de Assis, olhando do futuro, diria que a valorização excessiva da cor local seria, mesmo, a maior das agruras daquele movimento, na medida em que comprometeria o aprofundamento crítico das peças literárias do Romantismo e, ao mesmo tempo, macularia a intenção de uma literatura consistente e plena em termos de uma real originalidade e da exploração das subjetividades humanas em toda a sua potência. ${ }^{265}$

Gonçalves de Magalhães, no Ensaio de 1836, sinalizava que o índio singularizado, homogeneizado e negligenciado em sua pluralidade - deveria personificar a noção retrospectiva do ser brasileiro. Uma noção, cabe reiterar, frágil naquele tempo presente e que, por isso mesmo, carecia de uma gênese, de uma origem e de uma trajetória que, ficcional e factualmente, desenrolasse o novelo desde os tempos da Primeira Missa aos do Império do Brasil. A sinalização de Magalhães a respeito do índio como entidade da originalidade brasileira é precedida

\footnotetext{
${ }^{262}$ CARDOSO, Wright Eduardo. A cor local e a escrita da história no século XIX: o uso da retórica pictórica na historiografia nacional. Porto Alegre, RS: Editora FI, 2019.

${ }^{263}$ LIMA, Ivana Stolze. Cores, marcas e falas. Sentidos de mestiçagem no Império do Brasil. Rio de Janeiro: Arquivo Nacional, 2003, p.18.

${ }^{264}$ Wlad Godzich em artigo intitulado A ilegibilidade de Luiz Costa Lima chama a atenção para a crítica que seu autor-objeto realiza em Dispersa demanda: ensaios sobre literatura e teoria. Segundo Godzich, Luiz Costa Lima ao afirmar que "a literatura não é um instrumento nacional coletivo, nem um privilégio individual, pessoal (...)", contribuiria para o entendimento de que a literatura estaria para além dessa função reduzida imposta pelo contexto discursivo do Romantismo, constituindo, de modo muito mais amplo, expressão de "algo (...) essencial ao desenvolvimento dos seres humanos enquanto espécie." Ver: GODZICH, Wlad. A ilegibilidade de Luiz Costa Lima. In: GUMBRECHT, Hans Ulrich. \& ROCHA, João Cezar de Castro. Máscaras da mímeses: a obra de Luiz Costa Lima. Editora Record: RJ \&SP, 1999, p.349-50.

265 J. M. Machado de Assis. Obra completa. Rio de Janeiro: Ed. Nova Aguilar, 1962, 3 v.
} 
por uma crítica - recorrente em toda sua peça retórica- aos colonizadores portugueses,

(...) que viviam (...) de um trato vilíssimo salteando os pobres Índios, ou nos caminhos, ou em suas terras, servindo-se deles, e avexando-os contra todas as leis da razão. E mais abaixo diz ainda [refere-se a trecho de Crônica da Companhia de Jesus]: 'viviam (os Portugueses) do rapto dos Índios, e era tido o ofício de assalteaos [sic] por valentia; e por ele eram os homens estimados.' Tal era o estado daqueles tempos. (...) Tal era toda a indústria, a arte, e a ciência dos primeiros habitantes do Brasil. Triste é sem dúvida a recordação desta época, em que o Brasileiro, como lançado em uma terra estrangeira, duvidoso em seu próprio país vagava, sem que dizer pudesse: isto é meu, neste lugar nasci. Envergonhava-se de ser Brasileiro, e muitas vezes com o nome Português se acobertava, para ao menos aparecer como um ente da espécie humana, e poder alcançar um lugar em seu país. Destarte circunscrito em tão curto estádio, estranho à nacionalidade, sem o incentivo da glória, este novo povo vegetava. ${ }^{266}$ (grifos meus)

Para além de persuadir seus leitores do caráter antiético do projeto colonizador, Magalhães introduz, a partir desse momento de seu Ensaio, a ideia de que $o$ índio - sempre homogeneizado- por ter sido o primeiro habitante dessas terras, que são aqui retroativamente chamadas de Brasil, seria o Brasileiro na essência. Mais uma vez, a singularização opera no sentido da produção da identidade e, nessa esteira, o Brasileiro - no singular e com letra maiúscula- aparece como uma nova categoria, então associada à imagem do índio, que, por sua vez, tem sua identidade associada ao seu lugar de nascimento. Nessa esteira, $o$ índio seria o brasileiro legítimo, o único elemento pátrio original, o que explica a associação que Magalhães faz entre a posse do espaço e a pátria natal, quando diz: isto é meu, neste lugar nasci. Ele reafirma aqui a atualização comumente impressa pelos Estados independentes do Novo Mundo ao termo pátria, que passa a ter agregado ao seu sentido original de pertencimento local a dimensão da unidade territorial do novo país. Se faz pertinente recuperar aqui o que desenvolvemos no capítulo 1: a ideia de que, nos tempos anteriores à independência, o entendimento de nação pautava-se na prerrogativa de uma unidade atlântica, operando na chave “de uma única identidade nacional entre as diferentes partes componentes do mundo português" ${ }^{267}$. A essa altura, a ideia de pátria servia para designar o local de nascimento, assim, a pátria brasileira e a pátria lusitana conservavam suas

\footnotetext{
${ }^{266}$ Domingos José Gonçalves de Magalhães. Ensaio sobre a História da Literatura do Brasil. Nitheroy Revista Brasiliense. Tomo I, vol.1, Dauvin et Fontaine Libraires: Paris, 1836, p.140-1.

${ }^{267}$ PAMPLONA, Marco A. Pátria - Brasil. In: SEBÁSTIAN, Javier Fernandez (Dir.). Dicionario Politico y social del mundo ibero-americano. Tomo 8, Centro de Estudos Politicos y Constitucionales: Madrid, 2014, p.60.
} 
especificidades locais e compartilhavam uma noção de pertencimento comum ao mundo português, ou "à nação inteira de ambos os hemisférios." 268 Com o passar do tempo e com a potencialização do efeito nacionalizador dos Estados, a dimensão metafórica do conceito de pátria foi se complexificando. Nesse movimento, a subjetivação do termo foi se tornando mais ampla do que aquela experimentada à época das pequenas comunidades, e o entendimento de pátria foi sendo singularizado e interagindo com os conceitos de nação e reino, até se tornar, como expressa o excerto do Ensaio de Magalhães, sinonímia da ideia de nação. ${ }^{269}$

No mais, o historicismo romântico de Magalhães reivindica ao passado uma angústia de seu tempo presente, de seu lugar de fala, quando se solidariza com o índio por ter sido, enquanto categoria, expropriado em seu próprio país, em sua própria pátria, perdendo, assim, o direito ao que a boa sociedade oitocentista considerava legítimo: a posse/o pertencimento sobre/ao país de nascimento, algo completamente alheio às múltiplas compreensões de mundo compartilhadas pelas diversas nações de povos sul-americanos. Por essa via, se evidencia mais um traço da persistente perspectiva universalista do Romantismo em geral e de Magalhães em particular: o de defender o outro, aqui o índio, de acordo com os paradigmas de si, isto é, segundo a maneira brancal europeia de se colocar e de olhar o mundo, fazendo de si o geral ou, em outras palavras, do europeu o universal. ${ }^{270}$

Ainda sobre o passado de espessas trevas com o qual pretendiam romper para fundar uma nova empreitada civilizacional, Magalhães e seus companheiros editores da Nitheroy eram unânimes em afirmar que as potencialidades do Brasil foram por três séculos ofuscadas pela mentalidade escravista que atingia aos africanos e aos seus descendentes, como também aos próprios filhos do Brasil refere-se aos índios - para os quais "[os colonizadores] olhavam como para uma raça degenerada, inepta para tudo." 271 Grande o erro, no entender dos letrados

268 PAMPLONA, Marco A. Pátria - Brasil. In: SEBÁSTIAN, Javier Fernandez (Dir.). Dicionario Politico y social del mundo ibero-americano. Tomo 8, Centro de Estudos Politicos y Constitucionales: Madrid, 2014, p.60.

${ }^{269}$ A esse respeito, ver: PAMPLONA, Marco A. Nação. In: JUNIOR, João Feres (org.). Léxico da História dos conceitos políticos do Brasil. UFMG.

${ }^{270}$ Cabe reiterar aqui que as elites crioulas ibero-americanas se esforçavam para se colocarem como equivalentes ou assumirem a identidade do fenótipo branco/europeu. A esse respeito, ver: PRATT, Mary Louise. Imperial Eyes. Travel Writing and Transculturation. 2nd ed., London: Routledge, 2008. Ver também: TODOROV, Tzvedan. Nós e os outros: a reflexão francesa sobre a diversidade humana. Rio de Janeiro: Jorge Zahar Ed., 1993.

${ }^{271}$ Domingos José Gonçalves de Magalhães. Ensaio sobre a História da Literatura do Brasil. Nitheroy Revista Brasiliense. Tomo I, vol.1, Dauvin et Fontaine Libraires: Paris, 1836, p.139. 
residentes na Paris da década de 1830: em primeiro lugar, porque os ditos colonizadores não haviam sido capazes de reconhecer as virtudes específicas desses que, no contexto discursivo de Magalhães, eram considerados os primeiros brasileiros. E em segundo, porque tais práticas colocavam em questão a própria humanidade dos índios, que ao serem “(...) perseguidos com ferro e fogo como se fossem animais ferozes", ${ }^{272}$ eram equiparados aos povos menos afeitos à civilização e ao cristianismo. Implícita na reflexão de Magalhães, reside a compreensão, há muito compartilhada entre os letrados lusófonos, a respeito de uma diferenciação positiva do índio em relação ao negro. Isto porque, embora a prática escravista de modo geral o incomodasse, é em relação ao índio que manifesta sua maior indignação, sobretudo no que se referia ao tratamento degradante dado a esses primeiros brasileiros, o que teria implicado diretamente na ausência de originalidade dos escritos coloniais, limitando e desidratando as possibilidades de desenvolvimento das Artes, das Letras e das Ciências, afinal:

Quem, não tendo o conhecimento de sua própria existência, e só de cenas de miséria rodeiado [sic], pôde soltar riso de alegria, e exalar o pensamento de sua individualidade? Não; as Sciencias, a Poesia, e as Artes, filhas da Liberdade, não são partilhas do escravo; Irmãs da glória, fogem do país amaldiçoado onde a escravidão rasteja, e só com a Liberdade habitar podem. ${ }^{273}$

Pois, no que dependesse dos editores da Nitheroy, para romper com a inércia civilizacional gestada pelos colonizadores e, por muitos vieses, perpetuada pelo projeto independentista lavrado pela Constituição de 1824 - que, cabe lembrar, reiterou a escravidão de africanos e de seus filhos nascidos na América -, era preciso refundar, então, o Brasil, tendo como esteio a valorização do índio como genuíno representante da ideia de brasileiro que gestavam, e a superação do passadopresente escravista, unindo assim as pontas esparsas de um projeto de país que desde 1822 vinha tentando se definir por si próprio, mas que nem tão facilmente conseguiria se desvencilhar dos nós atados pelo colonialismo português.

\footnotetext{
272 Domingos José Gonçalves de Magalhães. Ensaio sobre a História da Literatura do Brasil. Nitheroy Revista Brasiliense. Tomo I, vol.1, Dauvin et Fontaine Libraires: Paris, 1836, p.140.

${ }^{273}$ Ibid., p.142-3.
} 


\subsection{O indianismo e a inferioridade reiterada}

A retórica de Gonçalves de Magalhães no decisivo Ensaio publicado na Nitheroy, em 1836, seria determinante para a abordagem que dali por diante os letrados adeptos do Romantismo desenvolveriam, sobretudo em relação a uma certa idealização do índio como elemento síntese da autenticidade brasileira. Autenticidade considerada fundamental tanto à originalidade literária quanto, em maior escala, à incubação do gérmen nacional que almejavam alavancar. Embora julgasse que o peso do arcaísmo português ainda entorpecia o progresso da civilização e da indústria, ${ }^{274}$ Magalhães apostava em uma espécie de redenção do Brasil através de uma persuasiva estratégia de enaltecimento do índio como índice incorruptível da gênese da pátria brasileira.

Acepção que não era inteiramente nova para os leitores de Rousseau e também de Chateaubriand. Referências que, em distintas ocasiões, haviam pensado sobre o lugar que o nativo americano deveria ocupar no mundo regulado pelo universalismo europeu, sugerindo, inclusive, que constituiriam uma nova possibilidade de que a humanidade recomeçasse sua marcha de modo mais virtuoso. De modo que, para Rousseau, os povos americanos, em sua condição original, estariam menos contaminados pelos vícios inerentes à civilização moderna, a qual seria a responsável, diz o mesmo Rousseau, pela “(...) maioria de nossos males (...) e que teríamos evitado quase todos se tivéssemos conservado a maneira simples, uniforme e solitária de viver prescrita pela natureza."275 Enquanto para Chateaubriand, já no limiar do Romantismo, tanto as populações nativas da América, quanto as recém contactadas da Oceania, poderiam servir como alternativa à implantação de um novo projeto civilizador, já que, no seu entender, a civilização europeia, e sobretudo a francesa, vinha sinalizando suas fraturas mais severas a partir das rupturas ocasionadas pelos processos revolucionários das últimas décadas. ${ }^{276}$

\footnotetext{
274 Domingos José Gonçalves de Magalhães. Ensaio sobre a História da Literatura do Brasil. Nitheroy Revista Brasiliense. Tomo I, vol.1, Dauvin et Fontaine Libraires: Paris, 1836, p.138. 275 Jean Jacques Rousseau. Discurso sobre a origem e o fundamento da desigualdade entre os homens. Coleção Pensadores: $1^{a}$ Edição, São Paulo: Abril S.A. Cultural e Industrial, 1973, p.247.

${ }^{276}$ HARTOG, François. Regimes de historicidade: presentismo e experiências do tempo. Belo Horizonte: Autêntica Editora, 2014.
} 
Nessa esteira, o que o arcabouço interpretativo europeu, compartilhado pelos letrados vivos na transição do XVIII para o XIX, podia perceber e transpor para a linguagem era a impressão de que os povos ditos nativos a eles cronologicamente contemporâneos pareciam viver em estágio anterior ao europeu. Ou seja, o que testemunhavam, quando em contato com populações nativas não cristianizadas ou não aldeadas, lhes pareciam uma espécie de encarnação de um passado remoto, ou mesmo pré-histórico. É o que Koselleck chama de contemporaneidade do não contemporâneo, ${ }^{277}$ sensação possível apenas a partir do século XVIII, quando o tempo da natureza fora submetido ao tempo histórico, ou quando "Kant e Buffon inauguraram um novo horizonte temporal, submetendo a Terra e todos os seres biológicos -animais e seres humanos- a uma perspectiva histórica."278 A essa compreensão da natureza, já explorada neste capítulo, corresponderia o que Koselleck nomeia estratificação do tempo. A metáfora espacial, diz ele, figura o que os sujeitos imersos no contexto discursivo da virada do XVIII para o XIX sentiam ao olhar para o passado, tanto coletiva quanto individualmente. A sensação era a de que várias camadas de tempo se sobrepunham, como em milenares formações geológicas, remetendo a diversas composições, de origens distintas, mas que existiam e agiam no mundo à mesma época. ${ }^{279}$

Partilhando desse entendimento do tempo como uma conjunção de múltiplos tempos que atuam simultaneamente, os brancos europeus, sem deixar de hierarquizar esses outros tempos, acabavam por vislumbrar os seres humanos desses outros contextos de experiência, como atrasados em relação ao seu modo de vida. Ocorre que esse outro tempo que se desenrolava concomitantemente ao tempo da civilização europeia era habitado e construído por um ser humano outro, não só na maneira de se colocar espiritualmente no mundo, como também nas suas características físicas, o que, àquela altura, configurava a ideia de uma outra raça. Como já pontuado neste capítulo, toda uma tradição retórica de inferiorização dos não-brancos, de muitas maneiras reiterada pelas vozes de filósofos e naturalistas imersos no contexto discursivo dos iluminismos, seria endossada por essa nova

\footnotetext{
${ }^{277}$ KOSELLECK, Reinhart. Estratos do tempo: estudos sobre história. $1^{\text {a }}$ Edição, Rio de janeiro: Contraponto: PUC-Rio, 2014.

${ }^{278}$ Ibid., p.10.

${ }^{279}$ Ibid., p.9.
} 
compreensão progressiva do tempo que ganha força justamente nessa transição do século XVIII para o XIX.

Pois, se a compreensão branca-europeia era a de que o seu tempo estava linearmente mais avançado do que aquele dos selvagens, então se fazia premente cooperar com esses povos para que eles se adiantassem na marcha da humanidade. Cabe lembrar, uma marcha de uma humanidade branca europeia, inventada e legitimada retoricamente por seus registros religiosos, filosóficos e científicos e propagada como se fosse a única forma de humanidade possível, aos outros exterminando, ou impondo seus modos de estar no mundo. Evidente que o objetivo da retórica civilizatória europeia não era de integração dos povos considerados inferiores, tampouco de promoção da equidade entre todos os tipos humanos. Havia, sim, uma preocupação direcionada à promoção de uma convivência que reforçasse o imaginário da superioridade branca e, simultaneamente, não permitisse que os povos não-brancos obstaculizassem os projetos políticos civilizatórios do arquétipo europeu, fosse nas Américas, na África ou na Oceania.

Embora as maneiras de vestir, comer, falar e reverenciar pudessem ser, em algum grau, convertidas, havia algo de irredutível: a alteridade física, a diferença fenotípica. Conforme desenvolvemos no primeiro capítulo, a diretriz do discurso mais hegemônico entre os ilustrados era a de que as diferenças comportamentais deveriam ser minimizadas para que esses contingentes de não-brancos fossem incorporados - a partir de uma perspectiva hierarquizada - ao projeto civilizacional conduzido por europeus, ou por seus descendentes no além-mar. Já entre os adeptos do Romantismo, no que se referia ao nativo americano, convinha, como já antecipamos, positivar a imagem do índio e, para atingir essa intenção, valia se reapropriar da ideia de bom selvagem, dela fazendo distintos usos contingenciais. Assim, recorrendo, em alguns enunciados, à perspectiva roussseauniana de valorização da inocência do índio como índice evidenciador da depravação dos nobres, tal qual se evoca no Emilio; ${ }^{280} \mathrm{e}$, em outros, àquela postura mais

280 Publicado por Rousseau em 1762, quase que imediatamente após a publicação d' $O$ Contrato Social, Emilio ou da Educação constitui parte da iniciativa preceptoria de Rousseau, defendendo a ideia de que a Educação de um ser possui três dimensões: a da natureza, a dos homens e a das coisas. E a educação como vinha sendo feita pelos colégios não servia ao engrandecimento do homem, mas apenas para que tivesse duas caras. Nesse sentido, Rousseau advogava em favor da potência da infância, enquanto fase regida mais pelo instinto do que pela consciência. Em função dessa aproximação entre infância e instinto, Rousseau sugere que uma educação mais próxima dos ritmos da Natureza fosse desempenhada na infância, de modo que a civilização artificial que se vinha 
aristocrática, presente em Chateaubriand, onde a noção de bom selvagem é utilizada como exemplo de grandeza oposta à grosseria burguesa. ${ }^{281}$

Fosse como fosse, o Romantismo enunciado pelo grupo de Magalhães precisaria recriar a ideia do índio, fazendo dela o uso que melhor conviesse ao projeto de Brasil que almejavam. E esse projeto possuía em seu cerne a conciliação entre dois dos temas mais correntes daquele contexto discursivo: natureza e civilização. A natureza como pano de boca de uma cena pátria encenada por índios virtuosos, inclinados à liberdade, insubordinados aos colonizadores, "com preferência ao cativeiro em cardumes [a] cair debaixo das espadas dos Portugueses, que embalde tentavam submetê-los a seu jugo tirânico". ${ }^{282}$ Essa era a cena que pintavam do passado: um passado pátrio inventado, habitado por um índio idealizado. Contudo, em relação ao presente e ao futuro, a natureza não seria suficiente para alçar o Brasil ao patamar que desejavam. Ao presente e ao futuro, a civilização se fazia imprescindível. O índio do presente não é aquele do passado. $\mathrm{O}$ índio do presente precisa ser civilizado, e essa ação civilizatória, para o Romantismo de modo geral e também para o grupo de Magalhães, está atravessada pelo Cristianismo, que atua como uma espécie de catalizador espiritual das engrenagens civilizatórias, conforme fica evidente tanto no Ensaio sobre a História da Literatura do Brasil, quanto no prefácio de Suspiros Poéticos e Saudades, ${ }^{283}$ ocasião na qual antecipa: “(...) nossa religião, nossa moral é aquela que nos ensinou o Filho de Deus, aquela que civilizou o mundo moderno, aquela que ilumina a Europa e a América: e só este bálsamo sagrado devem verter os cânticos dos poetas brasileiros. ${ }^{284}$

Essa moral cristã, a qual Magalhães se refere como civilizadora do mundo moderno, constitui uma espécie de atualização daquela mesma moral que, por séculos, chancelou, através da catequese, a inferiorização das populações originárias das Américas. Moral que remonta, portanto, ao tempo da chegada dos

implementando fosse superada em nome de uma sociedade de menos vícios, de menos artificialidades e de maior fluidez.

${ }^{281}$ BOSI, Alfredo. História concisa da Literatura Brasileira. 37ª edição, São Paulo: Cultrix, 1994, p. 195.

${ }^{282}$ Domingos José Gonçalves de Magalhães. Ensaio sobre a História da Literatura do Brasil. Nitheroy Revista Brasiliense. Tomo I, vol.1, Dauvin et Fontaine Libraires: Paris, 1836, p.157.

${ }^{283}$ Obra publicada por Domingos José Gonçalves de Magalhães no mesmo 1836 em que foi lançada a Nitheroy Revista Brasiliense.

${ }^{284}$ Domingos José Gonçalves de Magalhães. Suspiros poéticos e saudades. Ministério da Cultura, Fundação Biblioteca Nacional, Fundação Nacional do Livro, p.2. Disponível em: http://www.dominiopublico.gov.br/download/texto/bn000076.pdf 
europeus às Américas e à discussão sobre o grau de humanidade dos então chamados grupos acobreados. ${ }^{285}$ É a mesma moral, por fim, que reinveste de sentido, em plena modernidade, a premissa plantada pela Maldição de Cam de que os povos do Sul e os do Leste seriam os fadados à escravidão. Interessante como Magalhães, ao mesmo tempo em que é capaz de rechaçar a dúvida sobre a humanidade do índio, é capaz de enaltecer o empreendimento jesuíta por sua destreza em usar da música e da poesia para atrair "os selvagens [que] abandonavam seus desertos, e amoldavam-se ao Cristianismo, e à civilização."286

Tudo indica que seja mesmo indubitável essa inclinação de Magalhães e de seu grupo aos progressos possibilitados pelo que compreendiam como civilização, a saber: a contenção dos instintos, a valorização das Artes, das Letras e das Ciências, e a evolução progressiva da sociedade. Aliás, no mesmo prefácio de Suspiros Poéticos e Saudades está posta essa espécie de ode à civilização. Uma civilização de contornos cristãos e de essência ilustrada, orientada pela experiência do racionalismo francês, cujo viés religioso se justificava por sua associação com o subjetivismo característico do movimento romântico, enquanto sua adesão ao espectro civilizacional franco guardava relação com as pontes criadas, no pós 1808, entre o mundo dos saberes luso-americano e o francês. ${ }^{287}$ Elucidativa desse mosaico de referências, que mais reiterava a tópica ilustrada do que propriamente inaugurava uma arte madura, ${ }^{288}$ é a observação de Magalhães, no Ensaio, sobre o estado atual da civilização do Brasil, “(...) hoje filho da civilização francesa; e como Nação é filho desta revolução famosa, que balançou todos os tronos da Europa, e repartiu com os homens a púrpura, e os cetros dos reis. "289

Em que pesasse a cautela do movimento romântico em relação às revoluções que resultaram, em alguma medida, das sementes dos iluminismos, há aqui o reconhecimento da Revolução Francesa como agente descentralizador do poder, indicando que nem de tanto apego ao passado perene das aristocracias se constituía

\footnotetext{
${ }^{285}$ Tais afirmações acerca do traço racialista presente nos enunciados de Magalhães se apoiam no amplo exercício de historicização da retórica hierarquizadora dos povos presente na recente obra de Francisco Bethencourt. Ver: BETHENCOURT, Francisco. Racismos: das Cruzadas ao século XX. São Paulo: Companhia das Letras, 2018.

${ }^{286}$ Domingos José Gonçalves de Magalhães. Ensaio sobre a História da Literatura do Brasil. Nitheroy Revista Brasiliense. Tomo I, vol.1, Dauvin et Fontaine Libraires: Paris, 1836, p.156.

${ }^{287}$ COSTA, Wilma Peres. Viajantes europeus e o escrever da nação brasileira. In: DOYLE, Don H. \& PAMPLONA, Marco A. Nacionalismo no Novo Mundo. Editora Record: RJ e SP, 2008, p.306. ${ }^{288}$ A expressão é de Alfredo Bosi. Ver: BOSI, Alfredo. História concisa da Literatura Brasileira. $37^{\mathrm{a}}$ edição, São Paulo: Cultrix, 1994, p.87.

${ }^{289}$ Domingos José Gonçalves de Magalhães., op.cit., p.149.
} 
o Romantismo. As revoluções são tratadas, então, como "meios indispensáveis para o progresso do gênero humano", ${ }^{290}$ ocupando, portanto, um espaço relevante na marcha de melhoramento da humanidade. De qualquer modo, o grau de aceitação dessas transformações desencadeadas pelos processos revolucionários não era tão elevado na retórica romântica. Magalhães chega, inclusive, a atribuir às agitações revolucionárias um certo adormecimento da atividade poética, pois "quando elas agitam as sociedades, é verdade, a cansada Literatura para um pouco, e desmaiar parece", ${ }^{291}$ mas logo trata de interpretar a sua constatação de retrocesso da produção literária como apenas mais uma etapa inserida no mesmo destino progressivo da humanidade, dizendo que o adormecimento literário em tempos revolucionários serve para que depois ela “(...) continu[e] mais bela e remoçada em sua carreira.”292

De qualquer modo, as ideias de natureza e de civilização enunciadas no prefácio de Suspiros Poéticos e Saudades não parecem antagônicas como Rousseau as apresenta em seu celebre Discurso sobre a origem das desigualdades, ${ }^{293}$ mas sim complementares, mesmo porque servem à construção de temporalidades distintas. Isto é, quando Magalhães afirma no prefácio em questão que lhe “(...) causa[va] mesmo dó que cantasse o homem selvagem de preferência ao homem civilizado, como se aquele a este superasse, como se a civilização não fosse obra de Deus (...)" ${ }^{294}$ ele realiza um discernimento importante acerca da noção de selvagem, enquanto ser intimamente vinculado à ideia de natureza tão cara ao Romantismo, e a ideia de homem civilizado, como encarnação do ideal da razão ilustrada. E, mais ainda, está enunciada uma certa preponderância do civilizado em relação ao selvagem, indicando que a civilização, enquanto obra de Deus, havia formado homens que na marcha da humanidade superavam os ditos selvagens, então consideradas atrasados. Seria como dizer que a civilização, nos moldes do racionalismo cristão francês, constituiria uma etapa inerente ao desenvolvimento da espécie humana. Em última instância, a temporalidade do índio mitificado, virtuoso, era a de um passado distante, encantado, que com o presente e o futuro só

\footnotetext{
${ }^{290}$ Domingos José Gonçalves de Magalhães. Ensaio sobre a História da Literatura do Brasil. Nitheroy Revista Brasiliense. Tomo I, vol.1, Dauvin et Fontaine Libraires: Paris, 1836, p.152.

${ }^{291}$ Ibid., p.153.

${ }^{292}$ Ibid., p.153.

${ }^{293}$ Jean Jaques Rousseau. Discurso sobre a origem e o fundamento da desigualdade entre os homens. Coleção Pensadores: $1^{a}$ Edição, São Paulo: Abril S.A. Cultural e Industrial, 1973.

${ }^{294}$ Domingos José Gonçalves de Magalhães. Suspiros poéticos e saudades. Ministério da Cultura, Fundação Biblioteca Nacional, Fundação Nacional do Livro, p.2. Disponível em: http://www.dominiopublico.gov.br/download/texto/bn000076.pdf.
} 
preservava os laços subjetivos necessários à conformação da ideia de um Brasil supostamente latente naquele índio e naquela natureza de um passado imaginado. Enquanto isso, a temporalidade do homem civilizado era a do presente e a do porvir, já que o ingresso do Brasil no trilho do progresso, bem como sua sedimentação como nação, dependeria da ampliação da civilização da dita boa sociedade. Horizonte esse avistado apenas por esse restrito grupo - e para os seus iguais -, já que a proposta civilizatória do outro dizia respeito mais à garantia da convivência pacífica, na chave do adestramento, do que propriamente a um hipotético enriquecimento espiritual dos que consideravam, por esse e por outros vieses, inferiores. De outro modo, a dita boa sociedade, não por acaso composta por sujeitos autorreferenciados como brancos - ou que se queriam fazer parecer brancos- compartilhava um entendimento do presente e uma expectativa de futuro que via índios e negros como contingentes acessórios - e dispensáveis, inclusive a seu devir civilizatório, o devir moderno da branquitude. Ainda no que tange à inegociável adesão dessa branquitude à hegemônica agência civilizadora ocidental, bem como às pretensões de que o progresso civilizacional fizesse da pátria brasileira uma nação, Magalhães é enfático em determinar os afazeres de sua geração, afirmando:

Toca ao nosso século restaurar as ruínas, e reparar os erros dos passados séculos. Cada Nação livre reconhece hoje, mais que nunca, a necessidade de marchar. Marchar para uma Nação é engrandecer-se, é desenvolver todos os elementos da civilização. ${ }^{295}$

$\mathrm{Na}$ prática, no Brasil dos anos 1830, fragmentado socialmente pela manutenção da escravidão, assim como fragilizado politicamente pela abdicação de D. Pedro I, converter $o$ índio em elemento da genuinidade brasileira não seria tarefa tão óbvia como poderia, à primeira vista, parecer. Ciente disso, Magalhães se encarrega de desmontar, discursivamente, alguns estereótipos pejorativos aos quais os índios estavam associados, para então investi-los de um caráter admirável e autêntico, procurando reverter o imaginário que o vinculava à indolência e à decorrente indisposição para o trabalho nos moldes europeus. ${ }^{296}$ Magalhães, em

\footnotetext{
${ }^{295}$ Domingos José Gonçalves de Magalhães. Ensaio sobre a História da Literatura do Brasil. Nitheroy Revista Brasiliense. Tomo I, vol.1, Dauvin et Fontaine Libraires: Paris, 1836, p.144.

${ }^{296}$ Cabe reafirmar a intrínseca relação que se verifica entre a formulação e difusão de tais estereótipos e as diversas camadas sobrepostas de manifestações discursivas atravessadas por concepções racialistas.
} 
certo momento de seu Ensaio, deixa entrever as bases argumentativas que sustentam a apologia do índio em sua escrita. Ele parece sinalizar que essas bases estão ancoradas na "tão geralmente conhecida verdade [de que] a disposição e caráter de um país a mais decisiva influência exerce sobre o físico e moral de seus habitantes."297 Explico: quando Magalhães nesse seu texto seminal exalta os elementos da natureza e enaltece "este rico e imenso país da América, debaixo do mais belo céu situado, cortado de tão pujantes rios (...)"298, ele incorpora a essa sua retórica da valorização da paisagem, os seus habitantes originais, numa clara referência - e ele os cita nominalmente - a Buffon e Montesquieu, ${ }^{299}$ dois dos mais influentes pensadores do iluminismo francês a se debruçarem sobre as relações entre o ser humano e o espaço.

A essa altura, cabe retomar as observações já sinalizadas neste capítulo acerca da guinada operada pelo Romantismo na seara discursiva que apregoava a suposta implicação do clima na formação do caráter dos povos. De modo geral, tal guinada se inicia com o crescente encantamento dos viajantes estrangeiros pela natureza sul-americana, sobretudo a partir de 1804, com a publicação dos relatos de Humboldt, e se desdobra num crescente movimento de elogio de paisagens alheias aos parâmetros europeus. Movimento esse que, no contexto das independências ibero-americanas, acaba por se converter em estímulo aos autores e aos temas locais, sobretudo nas Artes e na Literatura, áreas caras, à propósito, ao empreendimento civilizacional abraçado pelo Romantismo. ${ }^{300}$ A apropriação que Magalhães e seu grupo realizam de Buffon e de Montesquieu opera ressignificando alguns aspectos e mantendo outros. ${ }^{301}$ Ressignifica, sobretudo, a abordagem em relação à natureza dos espaços tradicionalmente inferiorizados, considerada, tanto por Buffon quanto por Montesquieu, inóspita e exótica; mas, em contrapartida, reitera a tônica de que o caráter físico e moral dos povos era inteiramente

\footnotetext{
297 Domingos José Gonçalves de Magalhães. Ensaio sobre a História da Literatura do Brasil. Nitheroy Revista Brasiliense. Tomo I, vol.1, Dauvin et Fontaine Libraires: Paris, 1836, p.153.

${ }^{298}$ Ibid., p. 154.

${ }^{299}$ Ibid., p.153.

${ }^{300}$ De acordo com Flora Sussekind, as descrições realizadas por naturalistas e viajantes sobre a natureza americana contribuiriam de modo decisivo, como, aliás, já sinalizamos na primeira parte deste capítulo, para a formulação posterior de uma imagem-Brasil. Ver: SUSSEKIND, Flora. $O$ Brasil não é longe daqui. São Paulo: Companhia das letras, 1990. E ver também: KODAMA, Kaori. Os índios no Império do Brasil: a etnografia do IHGB entre as décadas de 1840 e 1860. SP / RJ: EDUSP / Editora Fiocruz, 2009.

${ }^{301}$ KURY, Lorelai Brilhante. No calor da pátria. Revista USP, São Paulo, nº72, p.80-89, dez. - fev. 2006-2007.
} 
determinado pelas condições climáticas do ambiente. Equação que resulta em uma literatura que enaltece a paisagem tropical e, por isso mesmo, é capaz de positivar e idealizar seu habitante original, sem, no entanto, equipará-lo ao padrão físico e moral da branquitude. Assim, reiterando, a todo tempo, a dupla face do que o Romantismo formula como sendo a virtude do índio: a face da ingenuidade/ da pureza e a da infância civilizacional, assim vislumbrando o índio como pedra bruta a ser lapidada, ou, em outras palavras, como tipo humano passível da tutela dos que supostamente já haviam alcançado a maturidade civilizacional, o que, com efeito, sugere a sobrevivência no Romantismo de concepções racialistas afinadas à retorica dos naturalistas do XVIII.

De qualquer modo, no Romantismo em favor do qual Magalhães panfleta estão intimamente imbricados os conceitos de natureza, povo e poesia, conforme é possível observar na associação que encerra o seu raciocínio a respeito da suposta vocação inata dos habitantes originais do Brasil para as Artes, ao dizer que "com tão felizes disposições da Natureza, o Brasil necessariamente inspirar deverá seus primeiros habitadores; os Brasileiros (refere-se aos índios) músicos e poetas nascer deviam." 302 Ora, deveria ser então uma característica inerente aos Brasileiros ${ }^{303}$ a habilidade para a música e para a poesia, dada a exuberância da paisagem que os cercava, afinal se o clima (natureza) interferiria diretamente no caráter dos povos, conforme afiançavam tantos naturalistas e filósofos setecentistas, ele incidiria também sobre a predisposição para a poesia e para a música. A esse respeito, Magalhães, já nas últimas páginas de seu Ensaio, arremata dizendo que:

Do que dito havemos, concluímos, que à Poesia não se opõe o país, antes pelas suas disposições físicas muito favo[rece] o desenvolvimento intelectual; e se até hoje a nossa Poesia não oferece um caráter inteiramente novo e particular, é que os Poetas, dominados pelos preceitos, atados pela imitação dos Antigos, que como diz Pope, é imitar mesmo a Natureza (como se a Natureza se ostentasse sempre a mesma nas regiões polares, e nos trópicos, e diversos sendo os costumes, as leis e as crenças, só a Poesia não partilhasse essa diversidade) não tiveram bastante força para despojarem-se do jugo dessas leis, as mais das vezes arbitrárias, daqueles, que se arrogam o direito de torturar o Genio, arvorando-se Legisladores do Parnaso. ${ }^{304}$

\footnotetext{
${ }^{302}$ Domingos José Gonçalves de Magalhães. Ensaio sobre a História da Literatura do Brasil. Nitheroy Revista Brasiliense. Tomo I, vol.1, Dauvin et Fontaine Libraires: Paris, 1836, p.155.

303 Aqui retomamos o termo Brasileiro, tal qual enunciado por Magalhães em seu Ensaio. O Brasileiro de Magalhães que evoca a ideia do índio idealizado de um passado remoto, usurpado e violentado pelos colonizadores em seu direito à terra na qual nascera, conforme desdobrado no item 3.2 deste capítulo.

${ }^{304}$ Domingos José Gonçalves de Magalhães., op.cit., p.157-8
} 
Toda essa construção argumentativa na intenção de comprovar que o Brasil possuía, desde os seus mais remotos tempos, elementos suficientes à inspiração poética, em verdade, possuía um objetivo maior: o de demonstrar que o índio considerado o Brasileiro original - fazia poesia, fazia música. Isto é, a Natureza do Brasil seria, há muito, suficientemente inspiradora de manifestações artísticas pátrias. Como se, a noção de pátria compartilhada naquele contexto discursivo do XIX pudesse estar presente na música e na poesia feitas no passado por Tamoyos, Caités e Tupinambás. ${ }^{305}$

\subsection{0 negro e o não-pertencimento à pátria do Brasil}

Pensar o negro como categoria implica em reconhecer as naturalizações que o signo incorporou ao longo do tempo, a começar por pontuar a sua invenção pela branquitude europeia como vocábulo designatório - e uniformizante - dos habitantes de um continente inteiro: o africano. Tal identificação de homens e mulheres de múltiplas etnias, das mais variadas latitudes de África, como tão somente negros, constituiu uma das mais eficazes estratégias intencionalmente esvaziadoras da pluralidade e da potencialidade de diversos e alheios povos habitantes do continente africano, identificando-os como se compartilhassem uma mesma essência, atribuindo-lhes uma designação marcadamente racial. $^{306} \mathrm{Se}$ pensarmos a própria ideia de raça, no sentido étnico, como um produto do contexto linguístico ibérico dos séculos XV e XVI, cunhado para definir as alteridades com as quais se deparavam à medida em que ampliavam a sua percepção espacial de mundo, conseguimos compreender uma face do discurso de verdade formulado pelos que se identificavam como brancos acerca da inferioridade racial do outro, fosse ele judeu, árabe, africano, ou americano. ${ }^{307}$

\footnotetext{
${ }^{305}$ Domingos José Gonçalves de Magalhães. Ensaio sobre a História da Literatura do Brasil. Nitheroy Revista Brasiliense. Tomo I, vol.1, Dauvin et Fontaine Libraires: Paris, 1836, p.155.

${ }^{306}$ MBEMBE, Achille. Crítica da razão negra. n-1 Edições, 2018, p. 41-2.

${ }^{307}$ De acordo com Francisco Bethencourt, o sentido étnico de raça começa a ser mobilizado pelos ibéricos - cristãos- ao tempo da Reconquista, para designar judeus e muçulmanos, como impuros de sangue. Ver: BETHENCOURT, Francisco. Racismos. São Paulo, Companhia das letras, 2018, p. 29.
} 
Não por acaso, a invenção do negro ${ }^{308}$ guarda relação com o desenrolar da era moderna e a crescente demanda por exorbitantes quantitativos de mão-de- obra que dessem conta de alavancar as grandes extensões de terra cultiváveis do Novo Mundo. Derivavam do mesmo movimento, pois, a inferiorização prática e linguística daqueles que constituíam as alteridades europeias no mundo atlântico que se descortinava. De outro modo, mas no mesmo sentido, Achille Mbembe afirma que:

(...) o negro não existe enquanto tal. Ele é constantemente produzido. Produzi-lo é gerar um vínculo social de sujeição e um corpo de extração, isto é, um corpo inteiramente exposto à vontade de um senhor e do qual nos esforçamos para obter um máximo de rendimento. ${ }^{309}$

O que se tornou o Brasil no século XIX foi resultado desse arranjo. Um arranjo que reiterou, cotidianamente, ao longo de três séculos de colonização, diversos discursos e práticas de inferiorização dos não-brancos, beneficiando econômica e psicologicamente aos que estiveram dispostos a se imporem como sujeitos universais. ${ }^{310}$ Em que pesassem as disputas e as diversas formas próprias de resistir dos povos considerados inferiores, os teólogos, os filósofos, os artistas e a própria burocracia do Antigo Regime se encarregava de ir definindo, ajustando e naturalizando no imaginário do senso comum qual era o padrão étnico, religioso e político. Assim, branquitude, cristandade e monarquismo constituíram os principais parâmetros definidores dos povos ditos superiores, enquanto aos demais, sobretudo aos que no mundo atlântico não se enquadravam nos tais parâmetros, restaria a conversão e/ou a escravidão.

Conforme já sinalizamos anteriormente, enquanto em relação aos nativos americanos havia uma hesitação maior em atestar legalmente a sua escravização, em relação aos contingentes advindos do continente africano, nomeados genericamente de negros, não havia qualquer pudor em referendar a sua inata propensão à escravidão. A preocupação do aparato estatal/religioso/filosófico do Antigo Regime em relação à escravização dos genericamente chamados índios tinha origem na condição de nativos americanos desses povos, ou seja, na sua legítima relação com a terra então ocupada majoritariamente por expedições

\footnotetext{
${ }^{308}$ MBEMBE, Achille. Crítica da razão negra. n-1 Edições, 2018, p.45.

${ }^{309}$ Ibid., p.42.

${ }^{310}$ TODOROV, Tzvedan. Nós e os outros: a reflexão francesa sobre a diversidade humana. Rio de Janeiro: Jorge Zahar Ed., 1993.
} 
ibéricas, o que colocava em questão se deveriam, ou não, ser considerados súditos da Coroa. Em meio aos debates filosófico-teológicos, que tiveram lugar nos séculos XVI e XVII, ${ }^{311}$ o aparato da branquitude inclinou-se a reconhecer a humanidade dos índios, considerando-os súditos e impondo uma série de limites à sua escravização. Essa guinada, é bem verdade, ofuscava uma espécie de reconhecimento acerca da dificuldade do colonizador branco em subjugar o nativo americano, conhecedor de sua terra, detentor dos segredos locais, que lhes permitiam fazer do meio um aliado importante para fugir ou derrotar seus algozes. De qualquer modo, o destino desses índios, súditos da Coroa, no entender do branco colonizador, deveria ser a conversão ao cristianismo e à toda cartilha comportamental a ele acoplada, mantendo-os, portanto, em posição hierarquicamente inferior ao europeu, mas, por outro lado, distanciando-os e elevando-os a patamar superior ao dos negros nessa escala de humanidade forjada pela retórica da branquitude seiscentista. Tudo isso para dizer que ao negro, a essa altura já sinonímia de africano, recairia o peso da escravização institucionalizada ou, em outras palavras, o fardo da migração forçada, assim como a violação imposta pela mercantilização de seus corpos e o funesto legado da condição jurídica de escravo aos seus descendentes.

Esse negro coisificado, destituído de qualquer traço de dignidade, apartado da própria ideia de humanidade, é o mesmo negro que chega ao século XIX, assiste às disputas pela conformação do Brasil independente, mas não vê, pelo menos até 1831, qualquer mudança político-jurídica no sentido de humanizar sua experiência no mundo. Com a Lei Feijó ${ }^{312}$ e a proibição da mercantilização de africanos nos portos do Brasil, se verificava uma sinalização em direção à condenação do tráfico de pessoas escravizadas por parte do Estado. No entanto, a fragilidade das instâncias fiscalizatórias combinadas aos vultuosos interesses financeiros em jogo, fizeram da Lei uma tímida contribuição do governo no sentido de colaborar com as articulações transatlânticas em prol da extinção do tráfico.

\footnotetext{
${ }^{311}$ No capítulo anterior a este, tais debates são problematizados em seus efeitos coetâneos, bem como em suas repercussões posteriores. À título de referência, reflexão consistente sobre o tema pode ser encontrada em: BETHENCOURT, Francisco. Racismos. São Paulo, Companhia das letras, 2018.

${ }^{312}$ Lei publicada em 7 de novembro de 1831 e que, grosso modo, proibia a entrada de escravos e de libertos estrangeiros nos portos do Brasil. Tal Lei será objeto de problematização no Capítulo 3 desta tese. Ver: Coleção de Leis do Império do Brasil - 1831, p.182. Disponível em: https://www2.camara.leg.br/legin/fed/lei_sn/1824-1899/lei-37659-7-novembro-1831-564776publicacaooriginal-88704-pl.html
} 
Poucos anos depois, mais precisamente em 1836, com o negro em condições análogas, surgiriam, como já apontamos, os primeiros rumores e as primeiras publicações de um Romantismo de contornos pátrios no Brasil. O cânone romântico, por todas as contingências que o gestaram, ${ }^{313}$ não foi capaz de fazer do negro sujeito de sua literatura, mas apenas objeto. ${ }^{314}$ Por se constituir como um movimento permeado pelos interesses dos grupos letrados da Corte, circunstancialmente em interlocução com franceses semeadores dos germens de seu nacionalismo romântico, o Romantismo brasileiro, apesar de crítico da prática escravista, ${ }^{315}$ fez reiterar os estereótipos negros compartilhados pela dita boa sociedade da época, assim endossando, em meio à costura da trama da nacionalidade, a inferioridade racial do negro, bem como seu alijamento do que procuravam definir como brasileiro.

O tom crítico em relação à escravidão que, por exemplo, Gonçalves de Magalhães e Torres-Homem adotam em seus respectivos textos publicados na Nitheroy tem origem antes em referências de um liberalismo econômico de contornos políticos moderados, ${ }^{316}$ do que em uma suposta consciência em relação à inferiorização racial do negro. De modo geral, a crítica de ambos à permanência do escravismo se assenta em duas bases congruentes: a do empecilho à plena civilização - sobretudo a dos brancos ${ }_{-}^{317}$ e a do atravancamento do desenvolver de

\footnotetext{
${ }^{313}$ Wayne Both, em seu estudo sobre a retórica da ficção, afirma que as limitações contingenciais condicionam toda a construção narrativa. Ver: BOOTH, Wayne. The rethoric of fiction. Chicago: University Chicago Press, 1982, p.160-1.

314 FILHO, Domício Proença. A trajetória do negro na literatura brasileira. Estudos Avançados, vol.18, no.50. São Paulo: Jan./Apr. 2004.

315 Tanto no Ensaio sobre a História da Literatura assinado por Domingos José Gonçalves de Magalhães, quanto nas Considerações Econômicas sobre a Escravatura, de autoria de Francisco Sales Torres-Homem, há menção clara à escravidão como entrave ao desenvolvimento civilizacional do país. Ver: Nitheroy Revista Brasiliense. Tomo I, vol.1, Dauvin et Fontaine Libraires: Paris, 1836. 316 As diversas faces que o liberalismo assume diante da realidade do Brasil independente já foram objeto de análises historiográficas consistentes, que procuraram mapear e identificar as nuances que distinguiam uns e outros grupos ao longo dos anos e das décadas de Monarquia no Brasil. Dos mais aguerridos -logo associados à ideia de republicanismo- passando pelos mais moderados -vinculados à preservação da centralização política através da monarquia constitucional-, aos mais conservadores -defensores da concentração de poder no Executivo-, outros tantos aspectos se encarregavam de subdividir esses grupos e criar novas legendas com novas bandeiras. E a defesa ou a condenação da escravidão constituía um desses pontos definidores, a partir do qual esses escritores da Nitheroy se definiriam e redefiniriam constantemente à medida em que se aproximavam ou se distanciavam das políticas de Estado que D. Pedro II e seus gabinetes implantariam a partir da década de 1840. A esse respeito ver: MATTOS, Ilmar Rohloff de. O tempo Saquarema. São Paulo: HUCITEC, 1987.

317 Tal formulação acerca dos danos causados pela escravidão aos senhores de escravos e à branquitude de modo geral já estava presente em José Bonifácio, o qual, por sua vez, recuperava apontamentos de Buffon a esse respeito. As enunciações ilustradas nesse sentido costumavam sinalizar que, para além dos danos óbvios causados às pessoas escravizadas, havia também prejuízos
} 
uma economia dinâmica ancorada na remuneração pelo trabalho livre. Nas Considerações Econômicas sobre a Escravatura, texto publicado na Revista

Nitheroy por Torres-Homem, sujeito filho de uma mulher negra alforriada e de um padre fenotipicamente branco, ${ }^{318}$ a argumentação em torno da ilegitimidade do tráfico de pessoas escravizadas e da própria escravatura em si está toda centrada nos prejuízos econômicos causados pelo que considerava a chaga roedora da antiga civilização. ${ }^{319} \mathrm{Na}$ compreensão dele, que desfrutava dos privilégios da branquitude, ${ }^{320}$ mas que chegou a ser descrito como impuro de sangue: ${ }^{321}$

(...) os suores do obreiro escravo jamais se vertem em chuva d'ouro para o proprietário, que menos funesto ao primeiro, do que ao segundo, é o fato da escravidão, e que se o livre trabalho em sua lata acepção é um dos destinos da espécie humana a título de instrumento primordial de toda a civilização, os povos que tem a desdita de engastar em seu solo os horrores da escravidão doméstica, comprometem de gravíssimo modo o seu porvir, afugentando, todo o prospecto de opulência, e prosperidade. ${ }^{322}$

Ainda a esse mesmo respeito, Torres Homem recorre a Tocqueville ${ }^{323}$ para endossar sua retórica liberal e reafirmar, a partir das palavras do autor francês em

ao caráter do escravista, bem como de todos aqueles que se identificavam com tal postura, na medida em que despertariam instintos agressivos e rotina de ócio improdutivo.

318 Conforme descreve R. Magalhães Junior, há uma certa dificuldade em se localizar referências consistentes sobre a origem de Francisco de Sales Torres-Homem, mesmo poque ele próprio teria feito questão de solapá-la o quanto fosse possível. Aliás, a própria biografia traçada pelo IHGB de F.S. Torres-Homem não menciona sua filiação, como de praxe nas descrições dos demais sócios. De todo modo, Magalhães Junior recupera os poucos relatos escritos por contemporâneos de F.S. Torres-Homem. Relatos que fazem referência à sua mãe como "uma preta quitandeira que estacionava no largo do Rosário para fazer o seu negócio" e a seu pai como "sacerdote, negocista, senhor de escravos, metido em brigas, de conduta tão escandalosa, que até acabou proibido de celebrar o ofício divino". A esse respeito, ver: Junior, R. Magalhães. Três panfletários do Império. Coleção Afrânio Peixoto. RJ: ABL, 2009, p. 10-11.

319 Francisco Sales Torres-Homem. Considerações econômicas sobre a escravatura. Nitheroy Revista Brasiliense, Tomo I, vol.1, Dauvin et Fontaine Libraires: Paris, 1836, p. 36.

${ }^{320}$ Os privilégios aos quais nos referimos guardam relação com o que não se apresentava como habitual a um sujeito do fenótipo de Torres Homem: a oportunidade de acessar aos estudos superiores no Brasil, viver a sociedade letrada parisiense e constituir-se um dos mais atuantes letrados da Corte.

321 Tal descrição de Torres-Homem é atribuída ao Padre João Manuel de Carvalho, que teria complementado sua constatação acerca da origem de seu contemporâneo, enaltecendo sua intelectualidade, afirmando que "sua impureza de sangue não o maculava a fidalguia do [seu] talento." Ver: Junior, R. Magalhães. Três panfletários do Império. Coleção Afrânio Peixoto. RJ: ABL, 2009, p. 11.

322 , Francisco Sales Torres-Homem., op.cit., p. 37.

${ }^{323}$ Cabe considerar o espaço que a obra de Alexis de Tocqueville, sobretudo o livro De la démocracie en Amérique ganha em meio aos românticos franceses e, por conseguinte, entre os letrados do Brasil que com eles dialogavam. De acordo com Hartog, houve como que uma "passagem de bastão" do velho Chateaubriand ao jovem Tocqueville, na medida em que, para além de compartilharem laços de parentesco e origens nobres, incursionaram pela América, em momentos distintos, atentos ao que a experiência do Novo Mundo e da Revolução Americana lhes poderia acrescentar. Tais incursões, separadas por um intervalo de quarenta anos, concluiriam, nos livros que delas derivaram respectivamente - Voyage em Amérique e a supracitada De la démocracie em 
relação aos Estados Unidos, que "a servidão tão cruel para o escravo, e[ra] ainda mais funesta ao senhor." ${ }^{324} \mathrm{O}$ momento do texto no qual recorre a tal autoridade discursiva para legitimar seus argumentos, é o mesmo no qual procura oferecer uma análise comparativa entre o Sul e o Norte dos EUA, demonstrando os prejuízos causados pelo escravismo ao Sul, à despeito de seu clima mais salubre que o do Norte. ${ }^{325}$ No desdobrar de suas ideias, Torres-Homem deixa entrever a lógica associativa que relaciona escravo, índio, deserto e floresta como elementos constitutivos de uma realidade de atraso e de barbárie espacialmente atrelada ao Sul. No polo oposto, discursivamente positivadas, estão as noções de indústria e de civilização, encampadas pelo que Torres-Homem considera ser o espírito do Americano do Norte, espírito esse que por ser alheio à escravidão é capaz de:

(...) afronta[r] a flecha do índio e os horrores do deserto; (...) marcha[r] em coluna contra a Floresta, sua natural inimiga, (...) apresentando o aspecto de um diluvio de indústria e de civilização, que sobe sem parar, e levanta a mão do Criador. ${ }^{326}$

Tal abordagem de Torres-Homem contra a escravidão acabava por constituir um persuasivo discurso, que possivelmente colaborou para engrossar as fileiras de brancos/ embranquecidos favoráveis à extinção não apenas do tráfico, como também da própria prática escravista, na medida em que passavam, cada vez mais, a significar um fardo para eles mesmos, enquanto indivíduos e como sociedade. No entanto, tais críticas à escravidão não podem ser confundidas com preocupação em relação ao sujeito escravizado. Não há, nas palavras de TorresHomem ou mesmo nas de Gonçalves de Magalhães, qualquer sinalização em relação à humanização do negro, fosse ele escravo ou liberto. Há sim, nas Considerações de Torres Homem, trechos flagrantes do quão cooptado ele, como sujeito miscigenado, estava pelo discurso da branquitude, aquele mesmo discurso que propalava a superioridade de uns a partir da inferiorização de outros, aqui

\footnotetext{
Amérique - primeiro, sobre a América como um refúgio, idealizada em sua pureza, liberdade e autenticidade do selvagem, e depois, como um laboratório do mundo novo, sem precedentes na História. Essa impressão de Tocqueville sobre o ineditismo da experiência americana, parece se evidenciar no seguinte trecho De la démocracie recuperado por Hartog: "remonto de século em século até a Antiguidade mais remota: não percebo nada que se pareça com o que está diante dos meus olhos." HARTOG, François. Regimes de historicidade: presentismo e experiências do tempo. Belo Horizonte: Autêntica Editora, 2014, p.127-9. A esse respeito, cabe mencionar também: RANGEL, Marcelo de Mello. Escravidão e decadência nos Estados Unidos e no Império do Brasil: Torres Homem e seu diálogo com Alexis de Tocqueville. Dimensões, vol. 29, 2012, p. 208-237.

${ }^{324}$ Francisco Sales Torres-Homem. Considerações econômicas sobre a escravatura. Nitheroy Revista Brasiliense, Tomo I, vol.1, Dauvin et Fontaine Libraires: Paris, 1836, p.55.

${ }^{325}$ Ibid., p. 52.

${ }^{326}$ Ibid., p. 54.
} 
especificamente a dos negros, aos quais ele mesmo se refere como ruim laia de população. ${ }^{327}$ Torres-Homem encarnava aquilo que a retórica civilizacional da branquitude esperava quando defendia o aperfeiçoamento das raças inferiores: ele se desfazia o tanto quanto podia dos indícios que denunciavam a sua ascendência negra. Sua adequação aos parâmetros de intelectualidade da branquitude letrada constituíam uma espécie de exemplo bem sucedido daquilo que acreditavam ser o poder civilizatório de melhorar os não-brancos. Mas haveria, a despeito de todos os seus esforços por demonstrar seu talento intelectual, algo de irredutível: sua fisionomia. Suas estratégias para parecer branco não só no espírito, como também na aparência - usando perucas, se vestindo como um parisiense- não seriam suficientes. Torres-Homem seria recorrentemente descrito, até pelos mais próximos, como uma figura de físico nada atraente, de "lábios grossos, olhos pardacentos, esbugalhados, e vasta cabeleira postiça." ${ }^{328}$ Nabuco de Araújo o ironizaria, evidenciando a lógica das concepções racialistas que, nas entrelinhas, informavam a persistência da hierarquização fenotípica, ao dizer: "Se o Sales não tivesse tanto talento era um peru de roda...só não digo pavão, porque este, segundo Buffon, é o rei da natureza em formosura."329

Em que pesassem as provocações, Torres-Homem se via integrado à dita boa sociedade e, como tal, encampava a sua retórica, que era também a retórica da branquitude civilizada. Ele se demonstrava, inclusive, convencido de que não bastaria superar a escravidão, seria preciso ainda "precaver-se contra um outro mal: a presença dos numerosos negros libertos. ${ }^{330}$ Sua fala se torna ainda mais aguda quando faz referência ao envio forçado de negros libertos do Sul dos EUA para a Libéria, território esse criado e assim nomeado por uma sociedade de colonização, dedicada a fazer permanecer em território americano apenas os negros úteis, ou seja, os escravizados. ${ }^{331}$ Aos que fossem libertos, caberia retornar ao continente de onde provinham, sem que fossem levados de volta a sua região ou ao seu povo de origem, sendo despejados em um estabelecimento criado artificialmente no intuito mesmo de configurar um depósito às pessoas que não serviam mais como escravas

\footnotetext{
327 Francisco Sales Torres-Homem. Considerações econômicas sobre a escravatura. Nitheroy Revista Brasiliense, Tomo I, vol.1, Dauvin et Fontaine Libraires: Paris, 1836, nota 1, p.75.

${ }^{328}$ Junior, R. Magalhães. Três panfletários do Império. Coleção Afrânio Peixoto. RJ: ABL, 2009, p.11-12.

${ }^{329}$ Ibid., p.13.

${ }^{330}$ Francisco Sales Torres-Homem., op.cit., p.75.

${ }^{331}$ Ibid., idem.
} 
e que, no entender da branquitude americana, não serviam também para serem cidadãos dos EUA. As palavras de Torres Homem que legitimam essa prática de remeter pessoas, como se coisas fossem, são mais uma demonstração da dimensão racialista que integra suas Considerações Econômicas sobre a escravatura, pois evidencia que não apenas os prejuízos econômicos ao projeto civilizatório da branquitude constituíam o problema, mas também a própria presença daqueles que considerava indolentes e incapazes. ${ }^{332} \mathrm{O}$ único inconveniente que conseguia perceber nesse deslocamento de negros libertos para a Libéria era de ordem financeira, sem, aliás, esboçar qualquer pudor em mencionar a ideia de eliminação da raça, como se pode verificar no trecho a seguir:

A sociedade de colonização tem calculado o transporte de cada liberto a 38 dólares (réis 38400). Ora que grandíssimo dispêndio não é mister fazer, para eliminar a raça negra, quando os nascimentos enchem por um lado o que a colonição [sic] vaza fora pelo outro. ${ }^{333}$ (grifo meu)

Interessante notar como os EUA, considerados em sua porção Norte, constituem, no entender de Torres-Homem, uma espécie de paradigma civilizacional possível de ser replicado no Novo Mundo. Tal compreensão carrega, intrinsecamente, a ideia de que o modelo bem sucedido da porção estadunidense do Atlântico Norte, calcado no trabalho livre e na industrialização, deveria se difundir por todo o espaço que, a esta altura, o Destino Manifesto já havia predestinado à branquitude americana de ascendência europeia, podendo servir, inclusive, de inspiração para a parcela da boa sociedade brasileira crítica do escravismo. Afinal, de acordo com a crescente adesão à retórica liberal cunhada nos jovens países independentes do Novo Mundo, o alcance da marcha do progresso parecia estar cada vez mais condicionado à adoção do trabalho livre e assalariado, aos moldes do que os EUA podiam duplamente exemplificar: tanto com sua experiência escravista ao Sul, quanto com sua realidade assalariada ao Norte.

Aliás, as diversas forças que contribuíram, por vezes à sua própria revelia, para que esse projeto de Estado e depois de nação estadunidense tomasse forma, compartilhavam um imaginário, aparentemente espontâneo e despretensioso, no qual a Revolução Americana, quase que predestinadamente, havia elevado os EUA ao patamar dos países europeus. Esse reposicionamento positivo da América do

\footnotetext{
332 Francisco Sales Torres-Homem. Considerações econômicas sobre a escravatura. Nitheroy Revista Brasiliense, Tomo I, vol.1, Dauvin et Fontaine Libraires: Paris, 1836, p.82.

${ }^{333}$ Francisco Sales Torres-Homem., op.cit., nota 1, p.75.
} 
Norte na retórica oitocentista advinha de uma constatação política: a de que os EUA foram pioneiros em romper com a ordem colonial e, portanto, com os ditames do colonialismo moderno. Mas havia ainda uma outra dimensão: aquela da retórica de hierarquização dos povos, pois se antes da Revolução Americana, todo o continente estava associado à ideia de que os povos originários do Novo Mundo eram intrinsecamente inferiores aos povos brancos do Velho Mundo, depois desse advento, a América do Norte passou a ser incorporada à noção positivada que tradicionalmente cabia aos povos do Norte, se aproximando daquilo que há séculos, mesmo muito antes de os europeus terem consciência da América, já se propagava a partir dos desígnios da Maldição de Cam. Conforme já mencionamos, essa tradição bíblica se fez precisa em afirmar que os povos amaldiçoados por Noé seriam os do Sul e os do Leste, o que, de alguma maneira, fazia da América do Norte - habitada por selvagens - uma experiência fora da curva, mesmo porque imprevisível ao tempo da escritura do Livro do Gênesis. Não obstante, a concomitância entre a Independência das Treze Colônias e a racialização cada vez mais contundente do discurso erudito ao longo do XVIII, reuniria condições bastante propícias para que, no alvorecer do XIX, fossem legitimadas tanto as campanhas contra os povos autóctones à Oeste, quanto contra os africanos e seus descendentes escravizados ao Sul do território americano.

Assim, talvez se tornem mais evidentes as concepções racialistas que subjazem à compreensão antiescravista de Torres-Homem, segundo a qual o escravismo do Sul -mas não só ele, como também seus vestígios humanosdeveriam ser extirpados do território estadunidense para que o caminho fosse, então, pavimentado pelos princípios civilizacionais irradiados pelo Norte. Fosse como fosse, fato é que essa concepção, impregnada de afirmações racistas, foi publicada na Revista que se tornaria fundadora do Romantismo no Brasil, bem como agenciadora da dimensão sensível da ideia de pátria brasileira, o que sugere muito acerca da formação da subjetividade coletiva, ou do imaginário nacional. ${ }^{334}$

Gonçalves de Magalhães, por sua vez, em Suspiros Poéticos e Saudades, dedica o trecho final do poema Invocação à saudade ao negro melancólico, saudoso

\footnotetext{
334 SCHWAB, Gabriele. Criando irrealidades: a mímeses como produção da diferença. In: GUMBRECHT, Hans Ulrich. \& ROCHA, João Cezar de Castro. Máscaras da mímeses: a obra de Luiz Costa Lima. Editora Record: RJ \&SP, 1999.
} 
de sua terra. ${ }^{335}$ Tal poetização da angústia daqueles identificados como negros, tanto os escravizados como os libertos, está associada, sobretudo, ao distanciamento que vivenciavam em relação a seu lugar de origem. Na ficção de Magalhães, a melancolia já ocupava um lugar importante. Ela era como que “(...) um fundamento da visão de mundo dos homens que compunham o Grupo de Paris." ${ }^{336}$ Isto é, uma espécie de sentimento compartilhado por todos aqueles que tomavam consciência, como era próprio daquele tempo, da brevidade da vida e da finitude humana. Com as lentes da melancolia, esses autores românticos enxergariam a existência do negro no Brasil e rascunhariam a sua imagem associada ao desamparo, à tristeza e, implicitamente, ao não pertencimento ao Brasil que se definia como nação. O trecho de Invocação à saudade, transcrito abaixo, demonstra a construção desse estereótipo negro, ${ }^{337}$ o do negro melancólico expatriado:

\footnotetext{
Oh terra do Brasil, terra querida,

Quantas vezes do mísero Africano

Te regaram as lágrimas saudosas?

Quantas vezes teus bosques repetiram

Magoados acentos

Do cântico do escravo,

Ao som dos duros golpes do machado?

Oh bárbara ambição, que sem piedade,

Cega e surda de Cristo a lei postergas,

E assoberbando mares, e perigos,

Vais infame roubar, não vãs riquezas,

Mas homens, que escravizas!

Mil vezes o Senhor, para punir-te,

Opôs ao teu baixel ondas, e ventos;

Mil vezes, mas embalde,

Nas cavernas do mar caiu gemendo.

Á voz do Eterno obediente a terra

Se mostra austera e parca,

Que a lágrima do escravo esteriliza

O terreno que orvalha.

A Natureza preza a Liberdade,
}

\footnotetext{
${ }^{335}$ FRANÇA, Jean M. Carvalho. Imagens do negro na literatura brasileira. SP: Brasiliense, 1998. p. 37.

${ }^{336}$ RANGEL, Marcelo de Mello. Poesia, história e economia política nos Suspiros Poéticos e Saudades e na Revista Niterói. Os primeiros Românticos e a civilização do Império do Brasil. Tese de Doutorado. PUC-Rio, 2011, p.27.

${ }^{337}$ De acordo com Domício Proença Filho, os estereótipos negros criados pelos autores românticos e disseminados no senso comum por suas obras não se restringiram ao do negro melancólico expatriado. Para além desse, as gerações de autores subsequentes à esta geração de Gonçalves de Magalhães, se encarregaria de formular e projetar literariamente estereótipos que, ao mesmo tempo, provinham e se destinavam ao senso comum, como por exemplo, o negro perturbador dos lares $e$ da família, o negro heroico, o negro amante e o negro enérgico trabalhador. Ver: FILHO, Domício Proença. A trajetória do negro na literatura brasileira. Estud. av. vol.18 no.50 São Paulo Jan./Apr. 2004.
} 
E só franqueia aos livres seus tesouros.

Oh suspirada, oh cara Liberdade,

Descende asinha do Africano à choça,

Seu pranto enxuga, quebra-lhe as cadeias,

E adoça-lhe da pátria a dor saudosa. ${ }^{338}$ (grifos meus)

Os termos grifados no poema nos ajudam a compreender as concepções de africano, de escravo e de pátria que atravessam a escrita de Magalhães. Nela, africano e escravo parecem ser utilizados como ideias sinônimas, o que muito provavelmente configura a transposição linguística da naturalizada associação entre a origem africana e a condição de escravo efetuada pelas elites brancas/embranquecidas do Novo Mundo. A nefasta vinculação, que de muitas maneiras a Literatura e a História se encarregaram de cristalizar, entre a ideia de escravidão e a sua personificação na imagem do negro, do africano, rendeu prejuízos humanitários capazes transcender o próprio fim do sistema escravista. $\mathrm{Na}$ esteira dessa retórica que só conseguia vislumbrar o corpo negro como corpo escravizado, servil, Magalhães deixa entrever nos últimos versos aqui transcritos, o seu entendimento - e o de seus pares - sobre o lugar desse imenso grupo de habitantes identificados como negros, ou como africanos na pátria que o Romantismo se encarregava de demarcar no imaginário dos habitantes do Brasil. Sua compreensão de pátria vinculava o pertencimento ao lugar de nascimento, o que quase automaticamente excluía o negro de origem africana da possibilidade de constituir-se como um ser integrante da pátria brasileira. Fosse o sujeito negro escravizado e nascido no Brasil, o que the conferia a alcunha de crioulo, ${ }^{339}$ a privação do pertencimento era da mesma ordem daquela do africano, já que aos escravizados, mesmo aos nascidos em solo brasileiro, não se aplicavam sequer as noções de equidade jurídica, tampouco a extensão da noção de brasileiro.

\footnotetext{
${ }^{338}$ D. J. Gonçalves de Magalhães. Invocação à saudade. In: Suspiros poéticos e saudades. Ministério da Cultura, Fundação Biblioteca Nacional.

${ }^{339} \mathrm{~A}$ alcunha crioulo servia como vocábulo designatório àqueles que descendiam de africanos, mas nasciam no Brasil. Nessa esteira, havia crioulos em situação de escravidão, já que o estatuto jurídico garantia que os filhos e filhas de pessoas escravizadas permaneceriam em cativeiro, assim como seus pais. Mas havia também crioulos em situação distinta, ou seja, crioulos livres, já que a prática da compra/ concessão da alforria era notória. A esse respeito, ver: WEINSTEIN, Barbara. Escravidão, cidadania e identidade nacional no Brasil e no Sul dos Estados Unidos. In: DOYLE, Don H. \& `PAMPLONA, Marco A.V. Nacionalismo no Novo Mundo. RJ / SP: Editora Record, 2008.p. 377-408.
} 
Tal alijamento metafórico do negro correspondia ao apartamento prático vivenciado pela população identificada como de cor, uma vez que a condição jurídica predominante desse contingente de pessoas estava associada ao estatuto da escravidão. Mesmo os que, nesse contexto dos anos 1830/1840, conseguissem se desvencilhar da condição jurídica de escravizados, não encontravam espaço, por sua característica fenotípica, para se identificarem como cidadãos da pátria brasileira, sobretudo porque, ou permaneciam trabalhando em condições análogas às da escravidão, ou possuíam ocupações que, por serem desprezadas pela etiqueta social da branquitude, acabavam por lhes associar a trabalhos braçais, que dispensavam qualificação intelectual. E assim permaneciam interditados de disputar o exercício pleno da cidadania, já que a Constituição vinculava tal exercício à renda e à propriedade. ${ }^{340}$ Subjetiva e pragmaticamente, ou literária e juridicamente, eram, portanto, tratados como alheios à ideia de brasileiro que se configurava.

Cabe reiterar, que nos referimos aqui ao negro como categoria, como identidade construída e marcada por noções de inferioridade. Mas é preciso considerar que, para além dessa categorização mais ampla, a população de pessoas miscigenadas experimentava, de acordo com suas possibilidades de acesso à escolaridade e aos recintos de sociabilidade produzidos pela branquitude, a sensação de que poderiam ser considerados pertencentes à noção de brasileiro que se delineava. A construção literária da figura do mulato, a propósito, reforçava tal possibilidade de que a população miscigenada poderia aderir aos padrões da branquitude, adquirindo traços de caráter identificados tradicionalmente à sensibilidade branca $^{341}$ Dentro do universo não tão amplo de peças ficcionais românticas protagonizadas por pessoas não-brancas, o mulato embranquecido foi a figura que ocupou esses espaços literários, como uma espécie de atenuação, ou mesmo de saída ficcional para a dura realidade de manutenção do escravismo que insistia em se colocar. ${ }^{342}$ Com efeito, é uma operação que forma uma subjetividade,

\footnotetext{
${ }^{340}$ A esse respeito, ver: PARRON, Tamis Peixoto. A política da escravidão no Império do Brasil (1826-1865). SP: Civilização Brasileira, 2011. Ver também: PEREIRA, Luisa Rauter. \& SENA, Hebert Faria de. A historicidade do político: o debate sobre representação e cidadania no Império Brasileiro (1823- 1840). Revista História da Historiografia. Ouro Preto, n. 22, dezembro/ 2016. p. 258-274.

${ }^{341}$ MELLO e SOUZA, Antônio Cândido. Formação da Literatura Brasileira. SP: Editora Ouro sobre Azul, 2020.

${ }^{342}$ FRANÇA, Jean M. Carvalho. Imagens do negro na literatura brasileira. SP: Brasiliense, 1998.
} 
ou delineia um imaginário coletivo, capaz de tolerar o pertencimento do mulato à ideia de pátria brasileira. Tolerar porque, a esses autores românticos formados na chave da retórica civilizatória impregnada de concepções racialistas, não lhes aprazia a ideia de incorporar o fenótipo do negro como sujeito brasileiro, mas dada a enorme parcela de pessoas miscigenadas habitando o território atribuído ao Império do Brasil, o que lhes restava era reconhecer o mulato como elemento constitutivo do imaginário brasileiro, mas sem deixar de realçar sua tendência física e moral ao branqueamento. ${ }^{343} \mathrm{O}$ poema épico A Independência do Brasil, de autoria de Teixeira e Sousa, ${ }^{344}$ ilustra bem essa aceitação enviesada da figura do mulato, eivada, aliás, de arraigadas concepções inferiorizantes das pessoas de cor, conforme demonstram os versos abaixo transcritos que apresentam, Gonzaga (branco) e Nunes (mulato), os dois heróis do poema:

Era o moço Gonzaga descendente

De pais d'Europa: belo era e formoso

De Nunes veio a avó d'África ardente

O avô da Europa: lindo era e garboso;

Destarte tinha a cútis o acidente

Entre o branco, entre o preto duvidoso;

Era Gonzaga branco, e na presença

Havia entre eles esta só diferença. ${ }^{345}$

De qualquer modo, embora o mulato precisasse lidar com um perene menosprezo associado à sua ascendência negra, lhe faziam crer na possibilidade de acessar ao arcabouço jurídico destinado aos brancos, justo em função de sua porção de branquitude. Já no que dizia respeito ao africano ou ao crioulo, escravizado ou livre, recaía um fardo ainda mais pesado. O fardo de camadas e camadas de discursos racialistas que por séculos, e por diversos vieses, fizeram do negro - não miscigenado - uma expressão quase que inumana do que compreendiam como

\footnotetext{
343 FILHO, Domício Proença. A trajetória do negro na literatura brasileira. Estud. av. vol.18 no.50 São Paulo Jan./Apr. 2004.

344 O poema ao qual fazemos referência foi publicado em 1847, portanto, nove anos depois da publicação da Revista Nitheroy e de Suspiros Poéticos e Saudades. Como constitui expressão do mesmo Romantismo em favor do qual atuava Gonçalves de Magalhães e seu grupo, consideramos pertinente citá-lo aqui, sobretudo porque enuncia a figura do mulato e deixa entrever algumas das muitas camadas de estereótipos racialistas subjacentes a essa aparente aceitação do mulato pela branquitude luso-americana. Cabe aqui pontuar que tal poema é coetâneo ao texto de K.F.P.von Martius, premiado pelo IHGB em 1847, no qual é aventada a ideia de que o povo brasileiro se definiria pela característica da mescla. Sobre isso nos aprofundaremos no último item do último capítulo desta tese.

${ }^{345}$ Antonio Gonçalves Teixeira e Sousa. A independência do Brasil. Rio de Janeiro. Tipografia de Paula Brito, vol. I, 1847, p.209.
} 
humanidade. ${ }^{346}$ Desse modo, como uma espécie de desdobramento espontâneo dessas arraigadas convicções que pautavam a existência dos que se percebiam brancos, não havia possibilidade léxica, ou mesmo coerência discursiva que desse conta de incorporar este outro, este negro tão alheio e tão rejeitado, ao projeto de pátria que, por princípio, se definia por aqueles que convinha apontar como mesmos.

Fosse como fosse, a poesia e a crítica romântica faziam ecoar temas tangentes a essa racialista construção da subjetividade patriótica, tais como a centralização monárquica e noções restritivas de cidadania. ${ }^{347}$ Tal esforço guardava relação com a crescente intimidade entre os maiores expoentes do cânone romântico dessa primeira fase, como Gonçalves de Magalhães, Gonçalves Dias, TorresHomem e Porto-Alegre, e os mais altos escalões governativos, consumando uma parceria que se tornaria essencial para ambos os lados: para os autores porque faziam literatura em um país desprovido de leitores, ${ }^{348}$ o que fazia do financiamento monárquico uma espécie de mecenato sem o qual a atividade dificilmente se sustentaria; e para o governo porque, esses letrados, pelas próprias características do Romantismo enquanto movimento, constituíam-se como valiosos aliados na tarefa de criar a estética nacional tão fundamental à sustentação dos Estados oitocentistas. Por essa via de mão dupla, na qual os letrados adeptos do Romantismo e a Monarquia se beneficiavam mutuamente, foram frequentes também, sobretudo a partir de 1840, nomeações de alguns deles a cargos públicos, assim como indicações de seus nomes ao quadro de sócios do Instituto Histórico e Geográfico Brasileiro, atrelando-os ainda mais aos interesses políticos e administrativos, o que, com efeito, acabava por pautar o fazer literário desses sujeitos.

\footnotetext{
${ }^{346}$ MBEMBE, Achille. Crítica da razão negra. n-1 Edições, 2018.

${ }^{347}$ Cabe demarcar que a noção de cidadania política no Brasil monárquico estava restrita àqueles que possuíam cabedal financeiro para elegerem e serem eleitos, o que acabava por ser ainda mais restritivo quando consideramos os arranjos de controle do poder público pelos grupos regionais locais, reservando o acesso às decisões políticas aos grupos -brancos/ embranquecidos - que compunham as elites luso-brasileiras há gerações. Em termos de cidadania civil, a garantia das liberdades clássicas - de ir e vir, de propriedade e da família -, bem como a liberdade de opinião e a integridade física eram privilégios apenas dos considerados cidadãos brasileiros, a saber: os brancos e os de cor nascidos livres, sendo vetado aos escravizados, fossem eles de origem africana ou nascidos no Brasil. A esse respeito, ver: MATTOS, Hebe. Os combates da memória: escravidão e liberdade nos arquivos orais de descendentes de escravos brasileiros. Revista Tempo, n6. Ver também: PEREIRA, Luisa Rauter. \& SENA, Hebert Faria de. A historicidade do político: o debate sobre representação e cidadaniano Império Brasileiro (1823- 1840). Revista História da Historiografia. Ouro Preto, n. 22, dezembro/ 2016. p. 258-274.

${ }^{348}$ Mello e Souza, Antônio Cândido. Literatura e Sociedade. $8^{\text {a }}$ edição, São Paulo: Publifolha, 2000 Coleção Grandes Nomes do Pensamento Brasileiro, p.74-5.
} 
Os canônicos autores do Romantismo conduziram, então, o delinear daquilo que Benedict Anderson chamou de comunidade imaginada, ${ }^{349}$ direcionando as consciências, em acordo com o patriotismo liberal cristão que os orientava, ${ }^{350}$ para a ideia de pertencimento nacional que intencionavam. Travestindo-se, ora de políticos, ora de intelectuais, lançando mão do patriotismo e do civismo como pretextos para se auto investirem da função de intérpretes didáticos do Brasil, ${ }^{351}$ através de seus romances procuravam tornar a literatura um lazer acessível, uma atividade prazerosa, em um país de tão poucos iniciados, ampliando, assim, o seu público leitor para além de seus pares. Dessa forma, buscavam fazer permear no imaginário do senso comum uma espécie de síntese do país. Nela, a idealização do passado remetia ao índio virtuoso e corajoso que habitava essas terras antes da implantação do que consideravam o malogrado empreendimento colonizador. Nela, a interpretação do presente-futuro, linear e progressivo, se resumia a uma aposta no Brasil independente e monárquico. Uma aposta que lhes parecia profícua se, e somente se, a boa sociedade branca e civilizada fosse capaz, em primeiro lugar, de extirpar o continuísmo mais nefasto dos tempos coloniais - a escravidão -, para depois encampar o projeto que alçaria o Brasil ao rol dos países civilizados.

Os propósitos que esses mesmos letrados compartilhavam, em suas diversas esferas de atuação, convergiam, de todo modo, para um mesmo objetivo: o da gestação de uma subjetividade nacional. Para tanto, viam na ampliação das práticas civilizatórias, na disseminação do sentimento patriótico e na garantia da ordem monárquica, os motores para que o Brasil, sob as bençãos do cristianismo, ${ }^{352}$ alcançasse o carro da civilização ${ }^{353}$ No entender de Torres-Homem, aliás, a

\footnotetext{
${ }^{349}$ ANDERSON, Benedict. Comunidades Imaginadas. Reflexões sobre a origem e a difusão do nacionalismo. São Paulo: Companhia das Letras, 2008.

${ }^{350}$ A referência aos redatores da Nitheroy como adeptos de um "patriotismo liberal cristão" é de Marcelo Rangel. Ver: RANGEL, Marcelo de Mello. Poesia, história e economia política nos Suspiros Poéticos e Saudades e na Revista Niterói. Os primeiros Românticos e a civilização do Império do Brasil. Tese de Doutorado. PUC-Rio, 2011.

${ }^{351}$ A expressão intérpretes didáticos é de Antônio Cândido. Ver: Mello e Souza, Antônio Cândido. Literatura e Sociedade. $8^{\text {a }}$ edição, Coleção Grandes Nomes do pensamento Brasileiro. São Paulo: Publifolha, 2000, p.78.

${ }^{352}$ Nos textos românticos que analisamos é recorrente a fidelidade do projeto e dos indivíduos letrados ao cristianismo. Críticos literários referenciais também reconhecem em tal inclinação religiosa fator determinante da conduta estética desses letrados. A esse respeito ver: BOSI, Alfredo. História Concisa da Literatura Brasileira. São Paulo: CULTRIX (37ª edição), 1994. Ver também: Mello e Souza, Antônio Cândido., op.cit.

${ }^{353}$ A expressão é de autoria de Francisco de Sales Torres-Homem, conforme mencionada na citação que se segue a esta nota. Ver: Francisco Sales Torres-Homem. Considerações econômicas sobre a escravatura. Nitheroy Revista Brasiliense, Tomo I, 1836, p. 39.
} 
resistência dos escravocratas em reconhecer as mazelas provocadas pela permanência da escravidão dificultavam o acesso do Brasil ao dito carro, atravancando o caminho, impedindo o desenvolvimento e, em última instância, apartando o país da irreversível marcha civilizacional. Em suas palavras:

(...) os interessados no status quo do sistema da escravidão ofendem a um só tempo o senso comum, e a experiência dos fatos, quando presumem, que a inteira cessação do trafego implica em suas consequências sacrifício da produção nacional, e desfalque nos benefícios da indústria particular; e igualmente deslembram-se dos conselhos da prudência, quando ouvindo rodar ao longe o carro da civilização, em vez de aparelhar-se para alcança-lo na passagem, e dentro também lançar-se, procuram ao contrário empecer-lhe a marcha com barrancos e aturados esforços. No fim de contas porém, e a despeito de todos os obstáculos, o carro tem de passar, e tem de passar, porque obedece em seu curso a uma lei infinitamente mais forte, que a vontade dos recalcitrantes, a Lei do progresso, e da civilização; somente em vez de leva-los por diante, pode abalroa-los com as suas rodagens. A história diz, que as grandes reformas se hão feito no mundo, não só a despeito, mas à custa dos que para elas se não achavam preparados. ${ }^{354}$ (grifo meu)

É, portanto, em nome do progresso que a escravidão deveria ser expurgada, assim como deveriam ser também os tipos humanos que a ela associados não conseguissem embarcar nesse carro da civilização. Não se tratava, pois, de findar uma prática violadora dos princípios humanos defendidos desde as revoluções atlânticas, mas sim de equalizar um problema que, econômica e moralmente, impedia as elites brancas/ embranquecidas de lançarem o Brasil na marcha do progresso. A literatura patriótica e ao mesmo tempo estatal que os autores da Nitheroy passam a encampar em seus textos críticos e ficcionais a partir de 1836, acaba por forjar uma estética nacional que atualiza uma premissa, de alguma maneira já anunciada pelo contexto discursivo dos letrados da geração da independência, de que eram as elites luso-americanas, identificadas como brancas, as representantes da ideia de cidadão brasileiro do Império do Brasil. A irrefutável presença de índios e negros deveria ser minimizada, ou mesmo silenciada, ao ponto que não constituíssem entraves aos avanços civilizacionais dessa branquitude, esforço para o qual a ficção romântica em muito contribuiria, costurando uma subjetividade pátria competente em rechaçá-los.

354 Francisco Sales Torres-Homem. Considerações econômicas sobre a escravatura. Nitheroy Revista Brasiliense, Tomo I, 1836, p. 39. 


\section{Um Estado, uma História, um povo: aparente unidade.}

Modo de ser de tudo o que nos é dado na experiência, a História tornou-se assim o incontornável de nosso pensamento. ${ }^{355}$

Michel Foucault

${ }^{355}$ FOUCAULT, Michel. As palavras e as coisas: uma arqueologia das ciências humanas. São Paulo, Martins, 2000. 


\subsection{O Regresso e a positivação do escravismo}

Desde os primórdios da fundação do Estado Imperial, a continuidade do tráfico transatlântico de pessoas escravizadas e a existência de povos americanos vivendo em suas condições originais constituíam questões inevitáveis aos articuladores políticos. Sujeitos herdeiros das tradições arremedadas pelas várias camadas de discursos racialistas, e que se viam envolvidos na definição e implementação de um projeto civilizatório de Brasil. Com a derrota das propostas de Bonifácio na Constituinte de 1823 e o avanço do grupo leal ao continuísmo que D. Pedro passou a representar, o Império do Brasil acabou por reiterar as estruturas sociais, que haviam, ao mesmo tempo, fundado e sido fundadas ao longo dos três séculos de colonização. Ou seja, o rompimento de D. Pedro com os Andrada e com os Constituintes de 1823, evidenciou as prerrogativas liberais com as quais o Imperador estava alinhado: o Brasil, enquanto país independente, haveria de assumir uma outra organização política que não aquela dos tempos coloniais, mas deveria, ao mesmo tempo, fazer com que essa nova ordem política fosse capaz de preservar os antigos interesses da classe senhorial. ${ }^{356}$ Interesses esses representados por privilégios não apenas determinados pelo lugar social de nascimento, mas também por critérios racialistas.

Não que a concepção de Estado de José Bonifácio e de seu grupo designasse propriamente uma ruptura em relação à ordem anterior. Muito ao contrário. Do ponto de vista político, aliás, Bonifácio havia apoiado o modelo constitucional de monarquia como expressão da moderação do discurso liberal que encampava. Em alguma medida, tal opção, combinada às articulações pela condução do herdeiro do trono português ao posto máximo da hierarquia política do novo país, expressava a

\footnotetext{
${ }^{356}$ Aqui fazemos menção ao conceito de classe senhorial desenvolvido por Ilmar Rohloff de Mattos para dar conta de nomear os grupos proprietários de terras e de escravos, produtores, sobretudo, de café, sediados no vale do Paraíba Fluminense. À propósito, cabe destacar que o uso da expressão classes senhoriais reflete uma escolha teórica de Ilmar Rohloff de Mattos. Sua escolha difere da de outros autores, como José Murilo de Carvalho e Ricardo Salles, os quais, posteriormente, se referiram a esse mesmo grupo como elite política e elite estadista, respectivamente. A esse respeito, ver: MATTOS, Ilmar Rohloff de. O tempo Saquarema. São Paulo: HUCITEC, 1987. Ver também: CARVAlHO, José Murilo de. A Construção da Ordem e Teatro das Sombras. Rio de Janeiro, EDUFRJ/Relume Dumará, 1996. Ver ainda: SALLES, Ricardo. O Império do Brasil no contexto do século XIX. Escravidão nacional, classe senhorial e intelectuais na formação do Estado. Almanack, Guarulhos, n.04, nov/2012.
} 
face continuísta do projeto independentista orquestrado pelos Andrada. ${ }^{357}$ Projeto esse, não se pode perder de vista, orientado pela dupla missão de garantir que o extenso território fosse preservado em sua integridade e que a dita boa sociedade, branca e civilizada, permanecesse desfrutando dos mesmos privilégios dos quais há pelo menos dois séculos se beneficiava.

Bonifácio, como um dos representantes ilustrados dessas elites lusoamericanas brancas e civilizadas, enxergava, assim como a maioria dos que compartilhavam a mesma tradição racialista, nos contingentes não-brancos a alteridade. Não obstante, avaliava que tais alteridades, na impossibilidade de sua invisibilidade, deveriam ser incorporadas ao que entendia como nação: um corpo político coeso, no qual seus componentes desfrutassem, desde que submetidos ao enquadramento civilizatório, das mesmas prerrogativas jurídicas. Ao sugerir a extinção imediata do tráfico escravista e a gradual emancipação das pessoas escravizadas, Bonifácio argumentava no sentido de que pretendia produzir critérios mínimos de homogeneidade civil, o que, na sua perspectiva, só seria possível quando os povos originários do território - povos indígenas-, assim como os africanos aqui residentes e os crioulos aqui nascidos, tivessem sua liberdade garantida e fossem submetidos aos parâmetros civilizatórios característicos das sociedades modernas. Nos textos nos quais desenvolveu tais argumentos, não havia qualquer intenção em suprimir as hierarquias raciais fundadoras dos privilégios das classes senhoriais brancas condutoras do empreendimento colonial e que, reinventadas pelas problematizações ilustradas - tal como bem expressava a trajetória do próprio Bonifácio - conduziriam também as articulações independentistas. Nesse sentido, os projetos que ofereceu à Constituinte, propunham que negros e índios fossem progressivamente equiparados, apenas e tão somente pela perspectiva jurídica, aos contingentes habilitados à cidadania. Tudo indica que o propósito de Bonifácio era o de demarcar as fronteiras da cidadania do nascente país com a régua da civilização. Assim, negros e índios, mesmo que

\footnotetext{
${ }^{357}$ É indispensável fugir da armadilha teleológica de considerar o projeto emancipacionista das elites de Rio de janeiro e de São Paulo como o preponderante desde os tempos de sua gestação. É preciso que todos os projetos autonomistas desenvolvidos nas mais diversas províncias, ao longo de pelo menos três décadas (1820-1840) sejam encarados como potenciais projetos de novos Estados. É necessário, nessa esteira, que se abandone a perspectiva pejorativa de que todos os projetos alheios ao capitaneado pelo Rio de Janeiro, sejam considerados separatistas. A esse respeito, ver: MELLO, Evaldo Cabral de Melo, A outra independência: o federalismo republicano de 1817 a 1824 . São Paulo: Editora 34, 2004. E ver também: SÁ, Maria Elisa Noronha de. Civilização e barbárie: a construção da ideia de nação: Brasil e Argentina. Rio de Janeiro: Garamond, 2012, p.12.
} 
continuassem a ser encarados pelos donos do poder ${ }^{358}$ como seres moral e fisicamente inferiores, poderiam, se submetidos aos parâmetros civilizatórios, compor o rol dos cidadãos brasileiros.

Como sabemos, tal pretensão de Bonifácio soou progressista demais, àquele investido de assegurar a contiguidade do território imperial. ${ }^{359} \mathrm{O}$ teor da carta constitucional aprovada pelo Imperador, então considerado dos maiores expoentes do liberalismo português, comprova sua resistência em admitir medidas legislativas capazes de reformular, mesmo que minimamente, o estatuto político-jurídico daqueles que pela cor da pele eram associados à ideia branca civilizada do que era mão-de-obra. Não havia, portanto, espaço para redefinições que extrapolassem as inevitáveis mudanças políticas decorrentes da emancipação. O próprio D. Pedro encarnava a metáfora da metrópole que continua a controlar sua colônia mesmo quando ela deixa de ser colônia. Todo o seu governo seria marcado por esse traço definidor: o da reacomodação das estruturas seculares ao novo estatuto político do Brasil, o que, colateralmente, acabava por beneficiar de forma contínua aos integrantes da dita boa sociedade, expressão maior das práticas e do imaginário dos que se denominavam brancos no mundo ibérico. ${ }^{360}$

Com a abdicação de D. Pedro e o descrédito do peculiar liberalismo que procurou implementar, as forças políticas se reorganizariam em torno de pautas

\footnotetext{
358 Aqui fazemos referência ao clássico homônimo de Raymundo Faoro. Ver: FAORO, Raymundo. Os donos do poder: formação do patronato político brasileiro. RJ: Editora Globo, 1997.

359 No contexto da prisão e deportação de José Bonifácio, os liberais mais conservadores que se aproximaram de D. Pedro I associaram a postura de Bonifácio e seus grupo a manifestações de republicanismo. Assim, o mesmo Bonifácio que havia colaborado no desenho desse projeto político de independência seria, sobretudo por conta da retórica antiescravista de sua Representação apresentada à Constituinte, banido por ser considerado uma ameaça às expectativas estadistas do Imperador. A respeito das tensões que se sucederam em meio à Constituinte e culminaram na sua dissolução e na prisão e deportação de vários de seus membros, entre eles José Bonifácio, ver: CARVALHO, José Murilo de; BASTOS, Lucia; BASILE, Marcelo. Constitucionalismo, liberalismo, nação. In: CARVALHO, José Murilo de; BASTOS, Lucia; BASILE, Marcelo (orgs.). Guerra literária: panfletos da independência (1820-1823). Vol.1: Cartas. Belo Horizonte: Editora UFMG, 2014. p.33-5. Já no que concerne às diversas camadas de apropriações do termo republicano na América portuguesa ao longo dos séculos XVII e XVIII (fundamentais para a compreensão dos usos do termo no contexto da independência), ver: STARLING, Heloisa Maria Murgel. Como ser republicano no Brasil colônia: uma tradição esquecida. São Paulo: Companhia das Letras, 2018.

${ }^{360}$ Cabe reafirmar que a categoria branco, assim como negro e índio, constituem construções discursivas que suprimem as diferenças étnicas em prol da criação de uma identidade fenotípica. As múltiplas origens étnicas presentes no que se considerava o branco ibérico são ilustrativas da estratégia retórica de produção de identidades supostamente raciais, que se justificariam por características físicas e psicológicas comuns. A esse respeito, ver: BETHENCOURT, Francisco. Racismos: das Cruzadas ao século XX. São Paulo: Companhia das Letras, 2018. E ver também: TODOROV, Tzvetan. Nós e os outros: a reflexão francesa sobre a diversidade humana. Rio de Janeiro: Jorge Zahar Ed., 1993.
} 
comprometidas em apresentar reformas capazes de limitar novas investidas autoritárias, freando assim as intenções restauradoras e, ao mesmo tempo, abrindo caminho para que os principais críticos do Imperador expusessem suas propostas. A essa altura, cabe lembrar, Bonifácio já tinha retornado de seu exílio involuntário na Europa e curiosamente sido nomeado, pelo mesmo D. Pedro que havia autorizado sua prisão por ocasião da Constituinte de 1823, como tutor do pequeno herdeiro do trono brasileiro. De qualquer modo, embora Bonifácio não protagonizasse mais a cena política do Rio de Janeiro, outros nomes surgiam e ganhavam importância no debate político que, desde o primeiro suspiro do Brasil independente, era atravessado por questões tangenciadas pela retórica racialista. Questões que insistiam em se colocar, pois implicavam, por um lado, na definição dos contingentes destinados à mão-de-obra e, por outro, na conformação identitária do que pretendiam definir como brasileiro. Então, os dirigentes políticos do país, balizados pelas noções racialistas que naturalizavam as hierarquias fenotípicas, se perguntavam: como lidar com os contingentes não-brancos habitantes do Império do Brasil? Como garantir quantitativo expressivo de mão-de-obra em um contexto discursivo atlântico cada vez mais crítico da escravidão? Como forjar a ideia de uma nação brasileira a partir de populações racialmente tão distintas? ${ }^{361}$

Bernardo Pereira de Vasconcelos foi um dos que conquistou espaço no debate legislativo ainda durante os anos em que D. Pedro governava. Sua atuação pública se estenderia até os anos finais da década de 1840 e sua potente oratória faria seu tom reverberar pelos salões legislativos, inspirando, sobretudo a partir de meados da década de 1830, a articulação do movimento popularizado pela historiografia como Regresso. ${ }^{362}$ Esse movimento, que na prática extrapolava em

${ }^{361} \mathrm{O}$ termo dirigentes é usado por Ilmar Rohloff de Mattos para se referir ao grupo de letrados/ intelectuais que ocupavam cargos decisivos da esfera política, como as cadeiras da Câmara, do Senado e do Conselho de Estado. Ver: MATTOS, Ilmar Rohloff de. O tempo Saquarema. São Paulo: HUCITEC, 1987. Embora tratemos aqui das variações argumentativas desses dirigentes sobretudo em torno da questão da mão-de -obra, vale salientar as observações de Ricardo Salles sobre esses dirigentes / intelectuais e a sua importância para a construção da hegemonia discursiva que daria o tom da consolidação do Estado, como um Estado escravista e centralizador. Remontando ao uso que Ilmar atribui ao termo dirigente, Ricardo Salles conclui: “(...) os intelectuais eram assim representantes e, mais importante, dirigentes da classe senhorial, e não de si mesmos. Quando deixaram de sê-lo, na conjuntura pautada pela ascensão do movimento abolicionista e das lutas escravas, entre 1885 e 1888, o Estado Imperial caiu." SALLES, Ricardo. O Império do Brasil no contexto do século XIX. Escravidão nacional, classe senhorial e intelectuais na formação do Estado. Almanack, Guarulhos, n.04, nov/2012, p.32.

${ }^{362}$ Bernardo Pereira de Vasconcelos (1795 -1850) acabou por inspirar aqueles que mais adiante formariam o grupo por Nabuco nomeado Trindade Saquarema. Seu legado aos Saquaremas seria o de um liberalismo conservador, traduzido na máxima do progresso dentro da ordem, e 
muito as esferas de decisão política propriamente ditas, se constituiu, na verdade, como uma espécie de sintetizador das frequências sociais, mais especificamente das frequências emitidas pelas classes senhoriais temerárias em relação ao avanço das pautas liberais, as quais incluíam as contendas em torno da extinção do tráfico e em relação à possível supressão da escravidão. ${ }^{363}$ No mesmo sentido, Ilmar Rohloff de Mattos advertiu que o avanço do Regresso representava uma ampla demanda dos homens livres do Império "pela difusão (...) dos valores, normas e padrões que distinguiam as nações civilizadas, mas de tal forma que, pela recuperação de um jogo de inversões, estes homens deveriam ver na civilização a face complementar da escravidão." 364

Como se pode notar, o chamado Regresso foi o movimento que emergiu de um tempo no qual elementos até então controversos passaram a coexistir como dois lados complementares. E, na esteira desse tempo, Vasconcelos foi hábil em alinhavar uma retórica simultaneamente liberal e escravista, da qual dependeria o avanço civilizacional do país. Com essa habilidade, Vasconcelos fez parecer plausível, por exemplo, que a escravidão contribuía para a civilização, operando, assim, uma completa reordenação retórica do discurso pró-escravista. ${ }^{365}$ Reordenação porque, do contexto da Independência até os anos finais da década de 1830, os argumentos favoráveis à continuidade da escravidão reconheciam, em sua maioria, o arcaísmo de tal prática e sua nocividade aos avanços civilizacionais, mas apoiavam-se, sobretudo, na ideia de sua indispensabilidade momentânea, ou na resiliente interpretação do mal necessário. ${ }^{366}$ A retórica da proficuidade

significativamente orientado pelo utilitarismo de Benthan. A esse respeito, ver: MATTOS, Ilmar Rohloff de. O tempo Saquarema. São Paulo: HUCITEC, 1987. Ver também: CARVALHO, José Murilo (org.) Bernardo Pereira de Vasconcelos (1795-1850). São Paulo: Editora 34, 1999.

363 O Regresso é compreendido pela historiografia como um movimento articulado em resposta ao avanço das pautas liberais no momento posterior à abdicação. Isto é, o Regresso como reação à Lei antitráfico de 1831, ao novo Código Criminal (1831) e ao Ato Adicional de 1834. Importante notar que tal compreensão remonta à análise de Justiniano José da Rocha, contemporâneo do Regresso e autor do célebre panfleto Ação, reação, transação. A esse respeito, ver: GUIMARÃES, Lucia Maria Paschoal. Justiniano José da Rocha (1812-1862) Ação: Reação: Transação. Duas palavras acerca da atualidade política do Brasil, pp. 199-204. In: PRADO, Maria Emília. Dicionário do pensamento brasileiro: obras politicas do Brasil imperial. Rio de Janeiro: Revan, 2012.

${ }^{364}$ MATTOS, Ilmar Rohloff de., op.cit., p.201.

365 Conforme demonstramos nos dois primeiros capítulos desta tese, tanto nos textos de José Bonifácio, no contexto dos anos 1820, quanto nos publicados por Gonçalves de Magalhães e Torres Homem na Revista Nitheroy, já no contexto do Romantismo dos anos de 1836 e 1837, a incompatibilidade entre escravidão e progresso civilizacional lhes parecia latente.

${ }^{366}$ Barbara Weinstein desenvolve análise sobre as variações discursivas em torno do tráfico e do escravismo, procurando demonstrar as nuances entre as concepções de "bem explícito ou mal necessário". A esse respeito, ver: WEINSTEIN, Barbara. Escravidão, cidadania e identidade 
civilizacional do escravismo era, aliás, a esse mesmo tempo, mobilizada por autores influentes do Sul dos EUA em meio às pressões pela abolição. ${ }^{367}$ Suas alegações, de modo geral, procuravam demonstrar que, no universo do capital, sempre haveria tensões entre os empregadores e os empregados, fossem eles livres ou escravizados. Assim, tentavam esvaziar as críticas às violações impostas pelo escravismo, comparando-as aos mecanismos de cerceamento e exploração que regiam os trabalhadores livres, enunciando o escravismo como uma instituição protetora. Proteção essa que se daria tanto em relação à manutenção da ordem, livrando a sociedade de tumultos e perigos, quanto em relação ao próprio sujeito escravizado, pois os livrariam do que os autores brancos do Sul diziam ser a verdadeira servidão do trabalho livre. ${ }^{368}$ Com o fortalecimento do Regresso entre os últimos anos da década de 1830 e os primeiros da década de 1840, ventos semelhantes aos do Sul dos EUA pareciam soprar também na capital do Império do Brasil. Não à toa, Vasconcelos, que encarnava uma das principais vozes do Regresso, teria espaço para enunciar, diante de seus pares legislativos, que "a África tem civilizado a América". ${ }^{369} \mathrm{Tal}$ fala só pôde ser dita porque havia um novo contexto discursivo, havia um clima propenso, havia, por fim, uma reorganização das forças políticas e sociais capazes de permitir que se elaborasse, enunciasse e produzisse sentido com essa colocação, justo nesse momento.

A atuação política de Vasconcelos adquiriu esses contornos à medida em que os pilares do liberalismo ao qual se filiava começaram a ser ameaçados. Se por um lado Vasconcelos demonstrou-se intolerante para com o centralismo de D. Pedro I, por outro, não pretendia colocar em risco aqueles pilares sobre os quais se assentavam os privilégios das classes senhoriais brancas, tais quais o escravismo e a unidade territorial do Império. Nessa esteira, à época de sua primeira legislatura, iniciada em 1826, dedicou boa parte de seus esforços retóricos a questionar a unilateralidade das determinações de D. Pedro e de seu ministério. Na Carta aos

nacional no Brasil e no Sul dos Estados Unidos. In: DOYLE, Don H. \& PAMPLONA, Marco A.V. Nacionalismo no Novo Mundo. RJ / SP: Editora Record, 2008, p.382.

${ }^{367}$ MCKIITRICK, Eric L. (org.). Slavery defended: the views of the Old South. Englewood Cliffs. N.J., 1963.

368 WEINSTEIN, Barbara. Escravidão, cidadania e identidade nacional no Brasil e no Sul dos Estados Unidos. In: DOYLE, Don H. \& `PAMPLONA, Marco A.V. Nacionalismo no Novo Mundo. RJ / SP: Editora Record, 2008, p.385.

${ }^{369}$ Bernardo Pereira de Vasconcelos. Discurso na Câmara dos Deputados, sessão de 25 de abril de 1843. In: CARVALHO, José Murilo (org.) Bernardo Pereira de Vasconcelos (1795-1850). São Paulo: Editora 34, 1999, p.268. 
senhores eleitores da província de Minas Gerais, denunciou, inclusive, que as violações à Constituição e o crescente despotismo e arbitrariedades estavam vinculados ao retardamento da instalação da Câmara, pois "não se tinham reunido os que tem todo o interesse na consolidação da monarquia, isto é, os srs. Deputados." 370

Em meio a esses enfrentamentos na dimensão da efetiva atuação do Legislativo, Vasconcelos discursou acerca do polêmico tema da escravidão em 3 de julho de 1827. Alguns comentadores, como José Murilo de Carvalho e Theo Lobarinhas Piñero, alertaram para a possibilidade de que a dita fala de Vasconcelos fosse toda ela perpassada pelo recurso da ironia. ${ }^{371}$ Embora haja considerável consenso em relação ao traço sarcástico e irônico de sua retórica, cabe observar essa fala de Vasconcelos em favor da extinção do tráfico com perícia, para que sejam evitadas as armadilhas teleológicas que comumente antecipam posições futuras, imputando a contextos discursivos distintos uma orientação desenvolvida posteriormente. Não nos parece, portanto, que toda a argumentação deste discurso de Vasconcelos tenha sido construída com a intenção de defender a permanência do tráfico, como que condizente com a postura por ele assumida, explicitamente, a partir do ano seguinte. Embora haja passagens nas quais o sarcasmo fique evidente, consideramos mais plausível que o texto expresse a já relativamente comum prerrogativa entre os monarquistas liberais de se opor ao tráfico, mas sem desconsiderar a escravidão.

Antes de nos concentrarmos em um exame mais pormenorizado do discurso de Vasconcelos, não seria exagero reafirmar a crucialidade da pauta do escravismo

\footnotetext{
370 Bernardo Pereira de Vasconcelos. Carta aos senhores eleitores da província de Minas Gerais, assinada em de 30 de dezembro de 1827. In: CARVALHO, José Murilo (org.) Bernardo Pereira de Vasconcelos (1795-1850). São Paulo: Editora 34, 1999, p.62.

${ }^{371} \mathrm{O}$ texto introdutório de José Murilo de Carvalho à coletânea de escritos de Bernardo Pereira de Vasconcelos, sugere que o discurso em questão fosse "ele todo uma grande ironia, no melhor estilo vasconceliano", pois registros do ano seguinte, produzidos pelo britânico Walsh, viajante e interlocutor do parlamentar brasileiro, já demonstravam a conhecida adesão de Vasconcelos ao tráfico e à escravidão. Ver: CARVALHO, José Murilo (org.)., op. cit., p.19. Já Théo Piñero, em artigo publicado cinco anos após a obra supracitada de José Murilo de Carvalho, aprofunda a discussão sobre o discurso em questão, sugerindo, também a partir dos escritos de Walsh, que a defesa vasconceliana do fim do tráfico seria uma espécie de cortina de fumaça à real intenção de "demonstrar que o governo imperial não deveria ter se comprometido com o tratado de 23 de novembro de 1826, que declarava ilegal o comércio de escravos no prazo de três anos após a sua ratificação." Nessa esteira, Piñero endossa a suspeita de Carvalho em relação à ironia contida na fala de Vasconcelos em relação ao fim do tráfico. A esse respeito, ver: PIÑERO, Théo Lobarinhas. Bernardo Pereira de Vasconcelos e a construção do império. Passagens. Revista Internacional de História Política e Cultura Jurídica Rio de Janeiro: vol. 6, no .3, setembro-dezembro, 2014, p. 424 5 .
} 
e, por conseguinte do tráfico. Como premente questão ao Estado, a essa altura já bastante pressionado pela diplomacia britânica, ${ }^{372}$ essa agenda se constituía indesviável na medida em que interferia diretamente na oferta de mão-de-obra à manutenção das lavouras, no comércio e, mais amplamente, na macroestrutura econômica do Império. Posto isso, passemos às palavras de Vasconcelos sobre o tráfico. Seu discurso é iniciado com a seguinte provocação: "qual de nós deixa de fazer os mais ardentes votos para ver terminado este flagelo que tem assolado a África, desonrado o mundo civilizado e afligido a humanidade, como reconheceu o Congresso de Viena? ${ }^{373}$ A esse trecho do discurso corresponderia a usual associação feita por liberais moderados entre o desumano tráfico de pessoas e o comprometimento dos avanços civilizacionais dos quais o Brasil tanto careceria, tal qual José Bonifácio advertia em sua Representação sobre a escravatura. ${ }^{374}$ Nessa esteira, a fala de Vasconcelos segue direcionada por uma contundente crítica ao tráfico associada a uma espécie de conformismo em relação à escravatura em si. Não obstante, em uma clara ode ao liberalismo britânico, chega a refletir sobre a produtividade do trabalho escravo se comparado ao trabalho livre e conclui dizendo que:

(...) o homem livre produz mais que o escravo, segundo os cálculos dos economistas; os escravos, senhores, não têm o estímulo da recompensa, nem segurança em seu estado, e o temor do castigo não pode suprir a estas faltas. ${ }^{375}$

Ironizando justificativas pró-tráfico, como aquelas que defendiam ser melhor aos africanos o destino da venda do que a morte reservada aos que não fossem comercializados, Vasconcelos disparava: "que grande humanidade! Degradar o homem de sua natural dignidade, reduzi-lo à condição de animal, darlhe uma morte mais lenta e mais dolorosa, pode em qualquer conjuntura considerar-

\footnotetext{
372 José Murilo de Carvalho informa em nota explicativa ao dito discurso de Vasconcelos na Câmara, que tal peça discursiva constituía resposta ao tratado anti-tráfico assinado em 23/11/1826, entre Brasil e Inglaterra. Por determinação do governo, esse tratado deveria ser referendado pela Câmara. Se referendado, o tratado determinaria que o tráfico de escravos se tornaria ilegal dentro do prazo de três anos. CARVALHO, José Murilo (org.) Bernardo Pereira de Vasconcelos (1795-1850). São Paulo: Editora 34, 1999, p.55

${ }^{373}$ Bernardo Pereira de Vasconcelos. Discurso na Câmara dos Deputados, sessão de 3 de julho de 1827. In: CARVALHO, José Murilo (org.) Bernardo Pereira de Vasconcelos (1795-1850). São Paulo: Editora 34, 1999, p.53.

${ }^{374}$ José Bonifácio de Andrada e Silva. Representação à Assembleia Geral Constituinte e Legislativa do Império do Brasil sobre a escravatura. Organização Miriam Dolhnikoff. São Paulo: Companhia das letras; Publifolha, 2000.

${ }^{375}$ Bernardo Pereira de Vasconcelos., op. cit., p.54.
} 
se benefício?"376 Por esse viés da desumanização imposta pelo tráfico aos escravizados, o discurso transcrito vai elencando uma série de argumentos que evidenciam o apoio aparentemente irrestrito de Vasconcelos ao fim do dito comércio. Nesse texto, sua compreensão sobre o escravismo e suas engrenagens de sustentação estão balizadas por dois princípios inseparáveis, o útil e o justo. ${ }^{377}$ No seu entender, a utilidade do trabalho escravo era inegável, mas tal constatação não deveria permitir que injustiças, como as praticadas nos porões insalubres das embarcações nas quais eram transportadas as pessoas escravizadas, continuassem a ocorrer. Sua expectativa, aliás, era a de que, na hipótese de supressão do tráfico, a povoação cativa que já habitava o solo do Império tenderia a se multiplicar, tanto porque a ela seria dispensado um melhor tratamento, como porque o clima do Brasil, por ser análogo ao clima de África - só com a diferença de ser mais saudável - estimularia o caráter prolífico da raça dos pretos. ${ }^{378}$ Como se pode notar, a argumentação de Vasconcelos em prol da abolição do tráfico estava direcionada pela otimista expectativa de que a oferta de mão-de-obra escrava não diminuísse, mas que fosse, inclusive, aumentada. Como que reproduzindo a teoria dos climas de Montesquieu, Vasconcelos afirmava ser o clima dos trópicos favorável à fertilidade característica da raça dos escravizados, verdade essa, dizia ele, confirmada por muitos fatos históricos. ${ }^{379}$

Depois de desenvolver seu ponto de vista acerca da questão, Vasconcelos arrematou, de modo direto e isento de sarcasmo, dizendo: "bem se vê que eu não posso reprovar a abolição deste tráfico." ${ }^{380}$ Isto para, na sequência, iniciar sua provocação ao governo, que, no seu entendimento, estaria remetendo à Câmara a responsabilidade de referendar o Tratado antitráfico assinado com a Inglaterra no ano anterior. De acordo com os extratos da Constituição citados em seu discurso, a Câmara não possuía a obrigação de referendar tratados assinados pelo governo, salvo aqueles que envolvessem cessão ou troca do território do Império. ${ }^{381}$ A partir dessa constatação, Vasconcelos sugere que o governo estaria, apenas por se tratar

\footnotetext{
${ }^{376}$ Bernardo Pereira de Vasconcelos. Discurso na Câmara dos Deputados, sessão de 3 de julho de 1827. In: CARVALHO, José Murilo (org.) Bernardo Pereira de Vasconcelos (1795-1850). São Paulo: Editora 34, 1999, p.53.

${ }^{377}$ Ibid., idem.

${ }^{378}$ Ibid., p.54.

${ }^{379}$ Ibid., idem.

${ }^{380}$ Ibid., p.55.

${ }^{381}$ Ibid., idem.
} 
de tema polêmico, remetendo o tratado para ser referendado pela Câmara, em vez de assumir a responsabilidade de chancelar a abolição do tráfico - agradando aos britânicos, mas despertando a ira dos setores diretamente afetados por tal mudança -, ou de romper o tratado - arriscando, assim, o bom relacionamento diplomático com os ingleses. No que concernia aos tais inevitáveis ônus com os quais o governo e os comerciantes de pessoas escravizadas teriam que lidar na possibilidade da efetiva abolição, Vasconcelos ponderava:

Não se pode duvidar que o comércio se sentirá desta abolição, pois que tem de dar nova aplicação aos capitais atualmente empregados neste tráfico; e nestes casos sempre há perda, qualquer que seja a nova aplicação. Mas o espaço de três anos minora o mal, e este sacrifício é devido aos imprescritíveis direitos da natureza. ${ }^{382}$

De todo modo, para além de sua opinião acerca do tráfico e da escravatura em si, o que estava em jogo nesse discurso de Vasconcelos era o papel da Câmara frente ao Imperador e seu Ministério, tanto que, ao abrir o discurso, já se antecipava a possíveis retaliações de seus pares e reconhecia a obviedade inerente em se defender o fim do tráfico perante às altas luzes e reconhecido liberalismo desta augusta Câmara. ${ }^{383}$ Nessa esteira, nos parece que o objetivo maior de Vasconcelos na ocasião desse discurso era o de expor as tensões entre o Executivo e o Legislativo. Em um contexto de violações à autonomia da Casa, caber à Câmara a validação de um tratado com implicações de tal envergadura, possuía, na sua compreensão, a intenção de tornar o parlamento, que há pouco mais de um ano havia sido instalado, impopular. A esse respeito alertava a seus ouvintes, fazendo, inclusive, ilações entre a figura de D. Pedro e a despótica figura de Napoleão:

Não queiramos pois uma atribuição, que além de nos não competir, pode suscitar contra nós o ódio popular; lembremo-nos que Napoleão, propondo-se a abolir todo o poder representativo na Constituição consular, investiu contudo as câmaras deste perigoso direito. ${ }^{384}$

Antes de encerrar o discurso, Vasconcelos emitiria ainda sua opinião sobre o que parecia criar controvérsia entre os parlamentares: as severas penas atribuídas aos que insistissem em traficar pessoas escravizadas após a efetivação do tratado. De acordo com suas observações, a definição das penas caberia à Assembleia Geral,

\footnotetext{
382 Bernardo Pereira de Vasconcelos. Discurso na Câmara dos Deputados, sessão de 3 de julho de 1827. In: CARVALHO, José Murilo (org.) Bernardo Pereira de Vasconcelos (1795-1850). São Paulo: Editora 34, 1999, p.54.

${ }^{383}$ Ibid., p.53.

${ }^{384}$ Ibid., p.56.
} 
o que não ocorreu. Pelo o que dá a entender, o enquadramento dos traficantes na pena de pirataria teria sido estabelecido pela articulação entre os representantes do governo de D. Pedro e os do governo britânico. No entanto, em nome da prudência, aconselhava seus pares a serem condescendentes com a nação britânica, evitando, assim, que se indispusessem com tão significativo parceiro comercial. ${ }^{385}$ Respondendo às conclusões tiradas pela comissão da Câmara no sentido de considerar exorbitantes as penas a serem fixadas sobre os traficantes de carne $e$ sangue humano, Vasconcelos seria taxativo em apoiar a aplicação de penas duras, já que as violações impostas pelo tráfico constituiriam, a essa altura, práticas inaceitáveis, uma vez que:

Nossos semelhantes roubados ou comprados, são atirados no porão dos navios; parte morre de sede e peste; parte é lançada ao mar como mercadoria avariada em ocasião de contágio, e a outra parte que sobrevive a tantas atrocidades satisfaz sua avareza em nossos mercados!!! Poderá duvidar-se que tais negociantes, se não são os autores de todos estes males, são ao menos cúmplices, e cúmplices tanto mais puníveis quanto mais refletida e mais premeditadamente obram? Homens que cometem tais crimes, que têm tanta facilidade em evadir-se às penas e tão forte incentivo em os perpetrar, não merecerão ser punidos com as penas mais severas dos códigos das nações? Eu entendo pois que sejam considerados como piratas e como tais punidos, os que depois de abolido o tráfico da escravatura o fizerem por qualquer modo. ${ }^{386}$

Por fim, sua fala, reiterava a crítica ao tráfico e afirmava seu apoio à inflexibilidade das penas. Não obstante, persuadia seus pares, por mais favoráveis que fossem ao cumprimento do tratado e à consequente abolição definitiva do tráfico, a aprovarem uma emenda capaz de os isentar de referendar o dito tratado, assim, retirando da Câmara a responsabilidade de ajuizar sobre tema tão espinhoso, recomendando que “(...) reenvia[sse] ao governo este tratado, reservando o seu juízo para tempo competente." 387 Conquistada a aprovação da emenda, Bernardo Pereira de Vasconcelos acabou por vencer a contenda, destinando ao governo os possíveis ônus relacionados à efetivação do dito tratado.

Nos anos seguintes, sobretudo a partir de 1835, Vasconcelos se inclinaria cada vez mais em direção ao argumento oposto, defendendo a continuidade do tráfico como uma espécie de fiador da perpetuação do escravismo que, por sua vez,

\footnotetext{
385 Bernardo Pereira de Vasconcelos. Discurso na Câmara dos Deputados, sessão de 3 de julho de 1827. In: CARVALHO, José Murilo (org.) Bernardo Pereira de Vasconcelos (1795-1850). São Paulo: Editora 34, 1999, p.56.

386 Ibid., p.57.

387 Ibid., idem.
} 
garantiria a preservação da estrutura agrária e das hierarquias sociais. Não que Vasconcelos tenha se transfigurado politicamente, ou abandonado o liberalismo. Seu compromisso continuava a ser, como sempre havia sido, com um liberalismo que defendia o progresso dentro da ordem, sendo fiel à monarquia constitucional $\mathrm{e}$ à preservação das hierarquias. Ocorre que pelo movimento autônomo e incontrolável das forças sociais, as reformas que idealizou e propôs com o intuito de frear os instintos autoritários de D. Pedro e depois dos Caramurus, acabaram por se converter em brechas para que grupos alheios às elites do Império, talvez afinados ao zeitgeist dos anos 1830, passassem a reivindicar suas próprias causas. ${ }^{388}$ Entre os diversos levantes contrários à ordem estabelecida, emergiram também os que mais preocuparam às classes senhoriais e, por extensão, aos dirigentes políticos: os organizados por grupos de pessoas escravizadas, como a Revolta de Carrancas, ${ }^{389}$ em Minas Gerais, e a Revolta dos Malês, em Salvador. ${ }^{390}$ De qualquer modo, o que importa extrair da variação retórica de Vasconcelos para as reflexões desta tese são dois aspectos: o primeiro tem a ver com a constatação de que os usos de argumentos relativos à manutenção ou à abolição do tráfico eram flutuantes, uma vez que condicionados pelas voláteis circunstâncias políticas; e o segundo guarda relação com uma camada anterior a esta externada nos debates públicos sobre a escravidão, trata-se, pois, das arraigadas concepções racialistas que orientavam tanto as opiniões mais progressistas, quanto as mais conservadoras a esse respeito, o que talvez ajude a explicar as oscilações discursivas de um mesmo personagem em referência ao tema do escravismo. Ou seja, apoiar ou condenar a engrenagem escravista constituía mais um posicionamento ligado a interesses políticos, do que ligado ao desenvolvimento de uma moral humanitária. Afinal, o entendimento compartilhado pelos dirigentes, e de modo bastante amplo pelos homens e mulheres livres do Império, era o de que

\footnotetext{
${ }^{388}$ Como crítico ferrenho do absolutismo do Imperador, Vasconcelos se dedicou a elaborar dois dos importantes projetos que liderariam a pauta antiautoritária depois da abdicação: a reforma do Código Criminal (aprovada em 1831) e o Ato Adicional à Constituição de 1824 (aprovado em 1834). A esse respeito, ver: CARVALHO, José Murilo (org.) Bernardo Pereira de Vasconcelos (1795-1850). São Paulo: Editora 34, 1999; ver também: PIÑERO, Théo Lobarinhas. Bernardo Pereira de Vasconcelos e a construção do império. Passagens. Revista Internacional de História Política e Cultura Jurídica Rio de Janeiro: vol. 6, no .3, setembro-dezembro, 2014, p. 415-438.

${ }^{389}$ ANDRADE, Marcos Ferreira de. A revolta de Carrancas: uma das rebeliões mais sangrentas da história da escravidão no Brasil. In FIGUEIREDO, Luciano. A era da escravidão. Rio de Janeiro: Sabin, 2009. pp. 51-58.

${ }^{390}$ REIS, João José. Rebelião escrava no Brasil: a história do levante dos malês em 1835. São Paulo: Companhia das Letras, 2003.
} 
os pretos - assim como os índios -, mesmo quando citados como seus semelhantes, eram seres inferiores. ${ }^{391}$ Aqui cabe reiterar a crescente adesão a concepções monogenistas das variações fenotípicas humanas. Tal entendimento partilhava a noção de uma origem comum a toda a humanidade e defendia, em linhas gerais, a ideia de que as diferenças físicas e morais características das raças teriam sido adquiridas a partir da interação dos grupos humanos com os diferentes ambientes e climas. ${ }^{392} \mathrm{O}$ próprio Vasconcelos, no mesmo discurso no qual defendia o fim do tráfico, se mostrava sensível à interpretação monogenista, ao exclamar:

Ah! Senhores, imitemos os estados americanos; o Brasil é hoje o único país do globo que ainda prossegue neste comércio; mudemos de conduta a respeito dos africanos em tudo nossos semelhantes, como provam os haitianos. ${ }^{393}$ (grifos meus)

Ora, em que pesasse essa concepção de que todos - brancos, índios e negros -fossem humanos, havia uma entranhada naturalização das hierarquias fenotípicas. Essa divisão da sociedade em patamares economicamente demarcados, mas antes de tudo, racialmente definidos, correspondiam às muitas camadas que, ao longo dos séculos, foram reafirmando, sob diversas chancelas, a verdade da superioridade branca. Abordar a questão por esse viés talvez contribua para que alarguemos as interpretações para além das motivações políticas e econômicas que claramente pautavam as decisões dos dirigentes do Brasil independente. Afinal, até que ponto, às pessoas livres que habitavam o Brasil, era conveniente se manterem fiéis aos paradigmas racialistas? E, igualmente, às subsequentes atitudes racistas deles decorrentes? Ou, até que ponto, reafirmar, mesmo que intimamente, a suposta inferioridade das pessoas de pele não-branca - mesmo as livres - não era fundamental para conservar a ordem?

Essa noção de escalonamento racial passaria a ser cada vez mais reiterada tanto no legislativo, quanto nos circuitos senhoriais, à medida que os desdobramentos das reformas liberais, implementadas nos primeiros anos da década de 1830, passaram a impactar não apenas à classe senhorial, mas também aos dirigentes e aos negociantes, uma vez que se perceberam afetados no que

\footnotetext{
${ }^{391}$ Bernardo Pereira de Vasconcelos. Discurso na Câmara dos Deputados, sessão de 3 de julho de 1827. In: CARVALHO, José Murilo (org.) Bernardo Pereira de Vasconcelos (1795-1850). São Paulo: Editora 34, 1999, p.54.

${ }^{392}$ BETHENCOURT, Francisco. Racismos: das Cruzadas ao século XX. São Paulo: Companhia das Letras, 2018.

${ }^{393}$ Bernardo Pereira de Vasconcelos., op. cit., p.54.
} 
entendiam e definiam como ordem. Ou seja, manter os contingentes populacionais não-brancos associados, de modo geral, ao trabalho braçal e, quando possível, à condição escrava contribuía para reforçar os paradigmas racialistas e a hierarquização social que deles derivavam e vice-versa. A imagem é a de uma engrenagem. Nela, as ideias determinam - e são também determinadas - pelas contingências. $\mathrm{O}$ entendimento de que aos grupos não-brancos estariam destinadas posições inferiores àquelas ocupadas pelos de pele e moral branca era então atualizado, assim como contribuía para atualizar as demandas contingenciais por mão-de-obra.

Com efeito, essa engrenagem garantia o funcionamento ordenado da máquina. As reformas implementadas depois da abdicação corresponderiam a ajustes nessa complexa engrenagem. Esses ajustes poderiam ter servido para reconfigurar a máquina em prol de um outro conceito de ordem, mais próximo das noções de equidade jurídica entre todos os habitantes do país, mas não. Acabaram sendo interpretados por Vasconcelos e pelos futuros integrantes do Regresso como entraves à manutenção daquele mesmo entendimento de ordem, que de alguma maneira era compartilhado desde os tempos coloniais. Isto é, a secular submissão estética, moral e física de índios, pardos e pretos deveria continuar se efetivando através da exploração de suas forças produtivas por aqueles que se identificavam como brancos e que, por isso mesmo, não se reconheciam como mão-de-obra - ou como sujeitos de trabalho braçal. Em última instância, manter essa submissão correspondia ao que senhores, negociantes, comerciantes e os idealizadores do Regresso compreendiam como a estabilidade necessária para que o seu Brasil progredisse, sem que a ordem - ou os seus privilégios- fossem ameaçados. ${ }^{394}$

Nessa esteira, a Lei de 7 de novembro de 1831, por declarar livres todos os escravos vindos de fora do Império do Brasil e impor penas aos importadores dos mesmos escravos, ${ }^{395}$ foi considerada por uma parcela dos latifundiários e dos que

\footnotetext{
${ }^{394}$ Ilmar Rohloff de Mattos sinaliza que o "racismo" atravessava todo o debate travado entre os "segmentos dos dirigentes", uma vez que diante da sempre latente escassez de mão-de-obra, se aventava a possibilidade de importar contingentes específicos de pessoas no intuito de submetê-las à exploração, como os coolies (de origem asiática), os chamados colonos africanos, ou aqueles pelos quais demonstravam explícita preferência: os imigrantes europeus. Preferência essa que correspondia à compreensão racialista de que grupos fenotipicamente identificados ao tipo branco seriam física e psicologicamente superiores. A esse respeito, ver: MATTOS, Ilmar Rohloff de. $O$ tempo Saquarema. São Paulo: HUCITEC, 1987, p.238.

${ }^{395}$ Ver Coleção de Leis do Império do Brasil - 1831, p.182. Acesso em 25/07/2020. Disponível em: https://www2.camara.leg.br/legin/fed/lei_sn/1824-1899/lei-37659-7-novembro-1831-564776publicacaooriginal-88704-pl.html.
} 
orbitavam seu raio de influência um elemento desconfigurador da engrenagem que garantia o bom funcionamento da máquina. Essa Lei, à propósito, seria amplamente debatida ao longo de toda a década de 1830, sendo pauta na Câmara, nos periódicos da Corte - protagonizando acaloradas disputas entre o Aurora Fluminense e o Sete d'Abril por exemplo- e até no IHGB, que fundado em 1838, dedicaria seus primeiros anos de atividades a pensar as demandas do presente como balizadoras da formulação da História Pátria que pretendiam produzir. Vasconcelos acusaria, inclusive, a Lei em questão de ter aberto precedentes para que a já mencionada revolta escrava de Malês ocorresse, já que a Lei reconhecia oficialmente a ilegalidade do tráfico e libertava, à revelia da vontade dos negociantes e/ou proprietários, as pessoas escravizadas que pisassem pela primeira vez em território brasileiro. ${ }^{396}$ Mas nem toda elite intelectual, nem todos os proprietários de escravos, enxergavam na Lei de 1831 um obstáculo à manutenção da ordem. Ao contrário, alguns viam, por exemplo, no seu artigo $7^{\circ}$, dedicado a impedir que qualquer homem liberto que não fosse brasileiro desembarcasse nos portos do Brasil, ${ }^{397}$ uma espécie de apoio à manutenção da estabilidade, pois esse artigo, quando associado ao propósito maior da Lei de impedir a entrada de novos escravos, garantia ainda mais: que o contingente de pretos no país - fossem eles escravizados ou livres não mais aumentasse. Isto, na concepção dessa vertente liberal da qual Vasconcelos vinha, aliás, se distanciando, implicava na diminuição da circulação de ideias revolucionárias ventiladas por pretos libertos, sobretudo os estrangeiros, aos pretos escravizados do Brasil. E, para além disso, constituía, de acordo com essa perspectiva moderada do liberalismo brasileiro, um primeiro passo em direção a uma provável eliminação definitiva da escravidão, uma vez que delimitava a população de pretos apenas aos radicados no Brasil e aos seus possíveis descendentes.

Diogo Antônio Feijó e Evaristo da Veiga seriam dois dos expoentes de peso da esfera pública a convergirem suas opiniões nesse sentido. Os mesmos Feijó e Evaristo que durante anos lutaram na mesma trincheira de Vasconcelos contra os desmandos de D. Pedro I, agora viam-se, então, distanciados dele, sobretudo em

\footnotetext{
396 RODRIGUES, Luaia da Silva. O Justo Meio: a política regressista de Bernardo Pereira de Vasconcelos (1835-1839). Dissertação de Mestrado, UFF, 2016.

${ }^{397}$ Ver Coleção de Leis do Império do Brasil - 1831, p.182. Acesso em 25/07/2020. Disponível em: https://www2.camara.leg.br/legin/fed/lei_sn/1824-1899/lei-37659-7-novembro-1831-564776publicacaooriginal-88704-pl.html
} 
função das oblíquas posições que assumiram em relação à questão do tráfico e do escravismo em si. O Sete d'Abril, em sua edição de 31/10/1835 publicou um artigo intitulado A Escravatura. Nele Evaristo é diretamente atacado, sendo inclusive chamado de Robespierre Brasileiro, em uma manobra discursiva que associava sua postura de crítica ao tráfico e à escravatura às do republicano francês. Há um trecho, em especial, no qual a argumentação pró-escravista dos editores do jornal -aliás, significativamente próximos de Vasconcelos- fica evidente. Observemos:

Em todas as Religiões, mestre Evaristo, em todas as seitas, a escravidão é considerada como um flagelo que faz parte da condição humana: nenhum dos fundadores de Religiões, nem Moysés, nem Confúcio, nem Mahometh, nem os Brachmanes da India, nem os Gymnosophistas do Egito pregaram a doutrina da extinção da escravatura. Invocamos aqui o testemunho do sábio Assessor da Sacra Camarilha; ele, que conhece, como as palmas de suas mãos, Platão e Aristóteles, diga se em algum dos livros de Platão, de Aristóteles e dos sete Sábios da Grécia, encontrou doutrinas para a extinção da escravatura!!! (...) Não fora pois, mestre Evaristo, os Brasileiros que inventaram o tráfico dos africanos; os Brasileiros só se aproveitaram dele: todos os príncipes, até mesmo Napoleão favoreceu esse tráfico. Não queremos contudo autorizar tratos desumanos, rigores condenáveis: às leis e às autoridades incumbe reprimir esses excessos. O que queremos dizer é que [como] Brasileiros achamos já estabelecido e autorizado este tráfico pelos costumes e pelos hábitos do país. ${ }^{398}$

Evocam-se, pois, as matrizes religiosas e laicas basilares dos referenciais interpretativos de mundo como esteio à defesa da escravidão e, ainda, à naturalização de tal condição a determinados povos, isentando os que nomeia de Brasileiros - leia-se aqueles que, por sua característica fenotípica, não estavam identificados a qualquer possibilidade de escravização - de possível culpa em relação à manutenção de tal prática. Cabe notar que o artigo supracitado foi publicado no Sete d'Abril em um ano chave para o movimento do Regresso. O apoio explícito à conservação de práticas já condenadas por boa parte dos pensadores atlânticos coetâneos, não ocuparia por acaso as páginas do jornal justo nesse ano de 1835. Fundado em 1833, o Sete d'Abril assumiria paulatinamente essa função de voz do Regresso na arena pública. Através de suas edições é possível acompanhar aquilo que já sinalizamos a partir de outras fontes: o cadenciado distanciamento de Vasconcelos de uma retórica liberal moderada - apoiadora do fim do tráfico, mas partidária das noções hierarquizantes das raças e da utilidade do escravismo - e sua

398 Sete d'Abril. Edição de 31/10/1835, p. 3. Acesso em 25/07/2020. Disponível em: http://memoria.bn.br/DocReader/docreader.aspx?bib=709476\&pasta=ano\%20183\&pesq=evaristo \&pagfis $=1211$ 
aproximação de uma retórica ainda liberal, mas mais conservadora, implicando não apenas na revogação das principais medidas descentralizadoras promulgadas pelo Ato Adicional, como também na revisão de sua posição a respeito do tráfico e da própria escravatura.

O fortalecimento das fileiras conectadas pela retórica de Vasconcelos na Câmara e endossada publicamente pelo Sete d'Abril fez ganhar espaço uma espécie de agudização do discurso liberal conservador sob diversos aspectos, sobretudo o pró-escravista e o favorável à recentralização dos poderes então concedidos às províncias, na contramão daquilo que estabelecia o Ato Adicional. Mas esse novo tempo, iniciado entre 1834 e 1835 e que é desenhado por Vasconcelos, tecido pela trindade saquarema ${ }^{399}$ e legitimado pelos grupos materialmente interessados em que a velha ordem não fosse posta em risco, foi também o tempo no qual outras parcelas da chamada boa sociedade, que não se identificavam com o Regresso - ou com os Saquaremas -, se organizaram para disputar os espaços discursivos, propondo visões alternativas a esta que parecia ter maior capacidade de cooptação dos grupos economicamente poderosos do país.

\subsection{Nuances racialistas do discurso antiescravista}

Em meio à presença cada vez mais contundente dos representantes saquaremas nos influentes cargos de Estado, ${ }^{400}$ ganhava fôlego, com a publicação da Nitheroy Revista Brasiliense, o movimento Romântico no Brasil, reunindo em torno de si os adeptos de um liberalismo moderado, patriótico e católico. ${ }^{401}$

\footnotetext{
${ }^{399}$ Integravam a dita Trindade Saquarema: Paulino José Soares de Sousa - Visconde do Uruguai -, Joaquim José Rodrigues Torres - Visconde de Itaboraí - e Eusebio de Queiroz Matoso da Câmara, todos ligados - fosse por nascimento ou por laços matrimoniais - aos grupos produtores de café do Vale do Paraíba fluminense, aos quais Ilmar Rohloff de Mattos chamou, em O tempo Saquarema, de classes senhoriais. A esse respeito, ver: MATTOS, Ilmar Rohloff de. O tempo Saquarema. São Paulo: HUCITEC, 1987. E para observar a análise dos vínculos entre os protagonistas saquaremas e os barões do café do Vale do Paraíba, ver: GUIMARÃES, Carlos Gabriel. Uma leitura sobre o Império do Brasil no contexto do século XIX: diálogo com Ricardo Salles. Almanack. Guarulhos. No 4. P.46-52. $2^{\circ}$ Semestre de 2012.

400 A esse respeito um dado chama a atenção: Paulino José Soares de Sousa foi Presidente da Província Fluminense entre 1836 e 1840 e nessa condição articulou, de acordo com Ilmar Rohloff de Mattos, a reação política ao Ato Adicional, convertendo o Rio de Janeiro de meados dos anos 1830 em uma espécie de laboratório saquarema. Ver: MATTOS, Ilmar Rohloff de., op. cit.

${ }^{401}$ Ver: RANGEL, Marcelo de Mello. Poesia, história e economia política nos Suspiros Poéticos e Saudades e na Revista Niterói. Os primeiros Românticos e a civilização do Império do Brasil. Tese de Doutorado. PUC-Rio, 2011.
} 
Publicada justamente em 1836, as duas únicas edições da Nitheroy procuravam despertar os letrados brasileiros para a construção de um pensamento independente, autônomo, que fosse capaz de apresentar interpretações do Brasil pela pena dos próprios brasileiros. Para tanto, os precursores do Romantismo reunidos na Nitheroy compartilharam, nas páginas da Revista, diagnósticos sobre o estado no qual se encontravam as áreas que entendiam serem estruturantes da noção de civilização que os pautava: a literatura, a economia e as ciências naturais. Conforme desenvolvemos no capítulo 2 desta tese, por mais afinados que os autores da Nitheroy fossem ao que o romantismo francês de Chateaubriand representava, por mais alinhados à ideia de que o progresso deveria ser alcançado sem sobressaltos, as sinalizações que emitiam sobre os ônus provocados pelo escravismo ao Brasil, os colocavam, no contexto político de 1836, em um lugar distinto daquele ocupado pelos identificados às ideias de Vasconcelos e aos interesses a ele associados.

Em linhas gerais, o liberalismo moderado patriótico dos Românticos da Nitheroy defendia o fim do escravismo, sobretudo porque entendia tal prática como uma espécie de obstáculo à entrada do Brasil na marcha das nações civilizadas. ${ }^{402}$ No entanto, essa postura não traduzia uma preocupação moral e muito menos uma expectativa de integração - mesmo que hierarquizada - das pessoas identificadas como negras. A interpretação desses autores da Nitheroy, que posteriormente integrariam inclusive os quadros do Instituto Histórico, era a de que os negros, fossem eles pretos africanos, ou mesmo pretos crioulos, não faziam parte da pátria brasileira, uma vez que seu pertencimento seria africano. À tal interpretação se agregava uma série de argumentos aparentemente sensíveis às usurpações materiais e subjetivas às quais foram expostas gerações e gerações de povos africanos arrancados de sua terra - ou de sua pátria como afirmavam os autores da Nitheroy. A leitura desses românticos era, portanto, a de que os negros eram afetados por uma melancolia quase que inerente à sua condição de escravo, mas também e sobretudo, provocada pela sua condição de expatriado. Assim, chegavam a sugerir que os negros habitantes do Brasil fossem devolvidos à África, o que, por um lado, constituía uma solução conveniente às expectativas de nação compartilhadas pelos sujeitos da boa sociedade, mas por outro, acendia um alerta a algumas parcelas

\footnotetext{
402 Esse tom está presente tanto no Ensaio sobre a História da Literatura de Gonçalves de Magalhães, quanto nas Considerações sobre a Escravatura de Francisco Torres-Homem. Ver: Nitheroy Revista Brasiliense, Tomo I, 1836.
} 
dessa mesma boa sociedade que os consideravam, apesar de indesejáveis, necessários, ou mesmo indispensáveis - tal como Vasconcelos e os adeptos de sua perspectiva.

Já no que tangia aos contingentes coetâneos de índios, o grupo da Nitheroy defendia que não mais fossem submetidos aos desmandos do servilismo - ainda persistente - mas fossem, sim, submetidos às estratégias civilizatórias para que assim pudessem integrar, mesmo que inferiorizados racialmente, a pátria brasileira. O tão popular índio, forjado pela poesia e pela prosa romântica, seria uma construção idealizada, relacionada ao índio puro de um passado distante, imune ao contato com o colonizador. Esse índio no qual residiria toda a essência do brasileiro servia, tão somente, como personagem da ficção de uma espécie de protonacionalismo brasileiro, anterior mesmo à chegada dos colonizadores. Aos índios reais, do presente, os Românticos da Nitheroy imputavam as ações civilizatórias que comumente destinavam aos identificados às ideias de atraso e de barbárie. Assim, a conversão ao cristianismo, à língua portuguesa e ao pertencimento ao Império do Brasil constituíam as principais estratégias de assimilação dos povos originários à pátria inventada pelas elites crioulas lusoamericanas.

Importa perceber que coexistiam diferentes modos da boa sociedade enxergar o lugar material e também moral dos grupos não-brancos. Essas ideias estavam em disputa nas revistas, nos jornais, nas poesias, nos panfletos, nas memórias, nas câmaras e nas ruas. O IHGB, fundado em 1838, seria mais um dos espaços atravessados por essas discussões. Longe de ser uma agremiação homogênea, ${ }^{403}$ o Instituto reunia em seus quadros, sócios que transitavam pelas nuances dos discursos moderados e conservadores. Pensado e criado por dois sujeitos conhecidos da cena política da Corte desde os anos 1820, e a essa altura filiados à Sociedade Auxiliadora da Indústria Nacional, ${ }^{404} \mathrm{o}$ Instituto dos primeiros anos, além de contar com a presença desses seus dois articulados fundadores -

\footnotetext{
${ }^{403}$ No artigo Polifonia e consenso nas páginas da Revista do IHGB: a questão da mão de obra no processo de consolidação da nação discuto justamente a aparente harmonia discursiva externada pela Revista do IHGB, frente aos debates revelados pelas atas das sessões ordinárias, sobretudo no que tangia à conveniência ou inconveniência da utilização da mão-de-obra involuntária de negros e indios. A esse respeito, ver: DIAS, Fabiana. Polifonia e consenso nas páginas da Revista do IHGB: a questão da mão de obra no processo de consolidação da nação. Revista História da Historiografia, Ouro Preto, número 05, Set./2010, p. 175-188.

${ }^{404}$ SILVA, José Luiz Werneck da. Isto é o que me parece: a Sociedade Auxiliadora da Indústria Nacional (1827-1904). Dissertação de Mestrado, UFF, 1979.
} 
Raimundo José da Cunha Matos e Januário da Cunha Barbosa - seria também frequentado por aqueles que, ligados a Aureliano de Sousa Coutinho, integrariam a chamada facção áulica e, como parte dela, seriam os responsáveis por articular o Golpe da Maioridade. ${ }^{405}$ Golpe esse que, nos bastidores, se configurou como uma manobra política orquestrada pelos liberais moderados com dois intuitos complementares: o de frear o avanço do Regresso e o de reaproximar dos círculos do poder os nomes remanescentes da cena da independência, então deles afastados pela ascensão dos chamados regressistas. ${ }^{406}$ Não seria casual a quase que imediata aproximação entre esses dirigentes do IHGB - chamados de áulicos por Vasconcelos - e o monarca. Aproximação, aliás, que acabaria por se converter em uma longa e decisiva relação de mecenato de D. Pedro II com o Instituto. ${ }^{407}$

Fosse como fosse, o fato era que no IHGB dos primeiros anos eram pautados, para além do conhecido propósito de reunir documentos com vistas a escrever a história pátria ${ }^{408}$ os assuntos conjunturais mais expressivos. Entre eles estavam duas questões associadas às múltiplas e sobrepostas camadas de discursos racialistas estruturantes da retórica da superioridade dos brancos/europeus: a utilidade da força de trabalho de negros e índios, e o lugar moral desses grupos no enredo nacional que precisavam definir.

Januário da Cunha Barbosa como fundador e Secretário Perpétuo do Instituto seria um dos maiores entusiastas da proposição de programas históricos dedicados a pensar a condição coetânea e pretérita de negros e índios. ${ }^{409}$ Este

\footnotetext{
${ }^{405}$ Facção áulica era o modo pelo qual Bernardo Pereira de Vasconcelos e seu grupo se referiam ao grupo que, liderado por Aureliano de Sousa Coutinho reunia liberais moderados (críticos de D. Pedro I) e veteranos caramurus (afinados a D. Pedro I). Cabe lembrar que, Vasconcelos tinha a origem de sua trajetória política nessa linha de moderados críticos do Imperador e, por volta de 1835, abandonou-a para construir uma terceira via: o chamado regresso conservador. A esse respeito, ver: GUIMARÃES, Lúcia Maria Paschoal. Debaixo da imediata proteção de Sua Majestade Imperial: o Instituto Histórico e Geográfico Brasileiro (1838-1889). In: R. IHGB, ano.156, n.388, p.459-613, jul./set. 1995. Ver também: RODRIGUES, Luaia da Silva. O Justo Meio: a política regressista de Bernardo Pereira de Vasconcelos (1835-1839). Dissertação de Mestrado, UFF, 2016.

406 CARVALHO, José Murilo (org.) Bernardo Pereira de Vasconcelos (1795-1850). São Paulo: Editora 34, 1999, p.30.

${ }^{407}$ Cabe observar que nenhum dos líderes saquaremas viriam a integrar o quadro de sócios do IHGB. Essa ausência se explica, em grande parte, pelo fato da facção áulica - envolvida na estruturação do Instituto - constituir uma espécie de oposição ao grupo dos Regressistas e ao que vinham conquistando em termos políticos. A esse respeito, ver: GUIMARÃES, Lúcia Maria Paschoal., op.cit.

${ }^{408}$ Ver RIHGB, Rio de Janeiro, tomo I, 1839, p.22-4.

409 A título de esclarecimento, os programas históricos eram proposições temáticas, comumente formuladas como indagações por um dos sócios do Instituto nas sessões ordinárias de periodicidade quinzenal. A rotina era a de que um ou mais sócios se predispusessem a discutir oralmente o tema em questão e que depois disso o desenvolvessem por escrito, na forma de dissertações. Depois de
} 
Januário era o mesmo que havia protagonizado disputas acaloradas com José Bonifácio por ocasião das diferenças entre os projetos de independência que encampavam. Naquela ocasião, era dele a voz propagada pelo Revérbero Constitucional Fluminense, um dos periódicos mais expressivos e, diga-se de passagem, mais progressistas da cena emancipacionista dos anos 1820. É certo que com o passar dos anos e com os novos arranjos políticos, o Cônego Januário foi abandonando a postura identificada pelos seus contemporâneos emancipacionistas como uma postura liberal radical e foi se aproximando de um discurso moderado. Através dos programas que propôs e das dissertações que desenvolveu em resposta a alguns deles é possível mensurar em que sentido apontavam suas convicções em relação à História do Brasil que os agremiados do Instituto pretendiam escrever, bem como seu entendimento acerca do papel que negros escravizados e índios deveriam desempenhar nessa trama.

Na sessão ordinária de 4 de fevereiro de 1839, o então Secretário Perpétuo do Instituto foi o responsável pela proposição de todos os seis programas históricos lançados. Desses seis, três tratavam exclusivamente da temática indígena e um da interface entre africanos e indígenas e todos remontavam à preocupação em torno das estratégias civilizatórias mais adequadas à conversão dos povos originários que viviam entranhados nos sertões. ${ }^{410}$ Em especial, esse dedicado a discutir a interface entre o uso da mão-de-obra indígena e africana traduz, em suas linhas e entrelinhas, o olhar não apenas do Secretário Perpétuo, mas também o consenso institucional em relação a estes que eram, antes de tudo, vistos como inferiores, atrasados e, por isso mesmo, destinados a servir - como força de trabalho - aos que se identificavam com a moral branca e se aproximavam fenotipicamente de seu ideal físico. $\mathrm{O}$

apresentada, a dissertação era também discutida oralmente pelos demais pares e, por fim, avaliada pelas comissões do Instituto, responsáveis por avalizá-las, ou não, à publicação na Revista do IHGB. A esse respeito dessa dinâmica, ver: DIAS, Fabiana Rodrigues. Por entre legados e demandas: um estudo sobre os programas históricos do IHGB (1838-1856). Dissertação de Mestrado, PPGH UERJ, 2009.

${ }^{410}$ Os três programas propostos por Januário tematizando os índios, intitulavam-se: 1. Quais sejam as causas da espantosa extinção das famílias indígenas que habitavam as províncias litorais do Brasil: se entre essas causas se deve numerar a expulsão dos jesuítas, que pareciam melhor saber o sistema de civilizar os indígenas; 2 . O que se deve concluir sobre a história dos indígenas ao momento da descoberta do Brasil; e daí por diante (...); 3. Qual seria hoje o melhor sistema de colonizar os índios do Brasil entranhados em nossos sertões; se conviria seguir o sistema dos jesuítas, fundado principalmente na propagação do cristianismo, ou se outro do qual se esperem melhores resultados do que os atuais. A esse respeito, ver: RIHGB (1), 1839; para observar a sistematização desta dinâmica de proposição de programas, ver: DIAS, Fabiana Rodrigues. Por entre legados e demandas: um estudo sobre os programas históricos do IHGB (1838-1856). Anexo. Dissertação de Mestrado, PPGH -UERJ, 2009, p.105-112. 
programa em questão continha em seu próprio título o questionamento retórico que daria o tom de seu desenvolvimento escrito: Se a introdução dos africanos no Brasil serve de embaraço à civilização dos índios, cujo trabalho lhes foi dispensado pelo dos escravos. Neste caso, qual é o prejuízo da lavoura brasileira entregue exclusivamente aos cativos? $?^{411}$

O texto escrito por Januário em resposta ao programa alavancado por ele mesmo é aberto com um alerta franco a respeito do lugar do qual o autor enunciava suas ideias: “(...) não sou patrono da escravidão, nem dos índios, nem dos negros: e por isso considero a liberdade como um dos melhores instrumentos da civilização dos povos." 412 Desse lugar, o de um homem, branco, católico e adepto de um discurso político moderado, Januário explanava suas convicções a respeito dos malefícios causados pela prática do escravismo, tanto em relação aos escravizados - fossem eles índios ou africanos - quanto em relação ao desenvolvimento econômico do país escravista. No seu entender, assim, aliás, como no de José Bonifácio e de Torres-Homem,

(...) os grilhões de uma miserável rotina nos embarga na carreira dos progressos industriais, que a tantos povos tem felicitado; e não queremos ver na escravatura africana um grande instrumento dessa detestável rotina. ${ }^{413}$

Se o clássico argumento liberal contra o escravismo não era novidade, o rumo que o texto segue, a partir de então, no sentido de atribuir à introdução de africanos - eles são reincidentemente mencionados como sinonímia da ideia de escravidão - as dificuldades encontradas em se civilizar os índios, constitui um artificio retórico pouco ou nada usual. Em suas palavras é possível notar um esforço por reconhecer, tal qual Domingos de Magalhães fizera, ${ }^{414}$ os equívocos cometidos pelos primeiros colonizadores que escravizaram de início os índios e depois os africanos, e com isso teriam comprometido o desenvolvimento civilizacional desta porção americana de Portugal. Nesse sentido, a tese de Januário da Cunha Barbosa é a de que havia uma espiral de erros, ainda alimentada pelos lavradores que

\footnotetext{
411 Januário da Cunha Barbosa. Programa Se a introdução dos africanos no Brasil serve de embaraço à civilização dos índios, cujo trabalho lhes foi dispensado pelo dos escravos. Neste caso, qual é o prejuízo da lavoura brasileira entregue exclusivamente aos cativos? RIHGB (1), 1839, p.123 -9.

412 Ibid., p.123.

${ }^{413}$ Ibid., p.128.

${ }^{414}$ Domingos José Gonçalves de Magalhães. Ensaio sobre a História da Literatura do Brasil. In: Nitheroy Revista Brasiliense: Sciencias, Letras e Artes. Tomo I. Dauvin et Fontaine Libraires: Paris, 1836.
} 
insistiam em recorrer aos africanos desde que os índios haviam deixado de estar disponíveis para serem escravizados. ${ }^{415}$ E essa continuidade do escravismo, elucubrava Januário, mesmo que não mais vitimasse aos povos americanos - pelo menos oficialmente - acabava por afugentá-los da catequese, pois temiam que fossem novamente escravizados. Assim, concluía sua crítica ao escravismo, afirmando que "como somos de opinião que só pela catequese se podem desentranhar os indígenas de suas matas, e trazê-los aos primeiros caminhos da civilização, cremos, por isso mesmo, que a introdução dos negros é um grande obstáculo a essa empresa." 416

Tais observações constituíam, portanto, para além de crítica ao passado colonizador escravista, análise dedicada a pensar possíveis soluções para três problemas coetâneos: a persistência da escravidão; as dificuldades em se arregimentar os índios para a catequese/ para a civilização; e a indesejável presença de negros - africanos ou crioulos - escravizados. Diferentemente do que considerava Vasconcelos a respeito da impossibilidade de que a força de trabalho dos negros escravizados fosse substituída sem prejuízos, Januário aventa uma possibilidade, aliás já sugerida anteriormente por José Bonifácio, de que os índios poderiam ocupar a vaga dos negros caso o escravismo fosse extinto. Dialogando, nas entrelinhas de seu texto, com as noções de escalonamento racial que, no mundo lusófono, atribuíam ao índio patamar mais positivo do que ao negro, Januário justificaria sua predileção pelos autóctones, no nível mais acessível de seu texto, por argumentos de ordem prática, como, por exemplo, quando afirma que "a experiência nos mostra que os índios são aptos para todos os trabalhos a que se apliquem, ou em terra, ou nos rios e mares. O que hoje fazem os negros, eles o faziam." 417

As expectativas do fundador e Secretário Perpétuo do IHGB em relação aos povos indígenas sobreviventes era a de que, a longo prazo, pudessem se converter no maior contingente de mão-de-obra livre do Império. Tal prognóstico estava

\footnotetext{
415 Januário faz uma longa digressão sobre a trajetória das leis que foram dificultando a escravização dos povos americanos até que a prática fosse definitivamente proibida em meados da década de 1750. Ver: Januário da Cunha Barbosa. Programa Se a introdução dos africanos no Brasil serve de embaraço à civilização dos índios, cujo trabalho lhes foi dispensado pelo dos escravos. Neste caso, qual é o prejuízo da lavoura brasileira entregue exclusivamente aos cativos? RIHGB (1), 1839, p.126.

416 Januário da Cunha Barbosa., op. cit., p.127.

${ }^{417}$ Ibid., p. 128 .
} 
orientado por prerrogativas que remetiam às referências ilustradas com as quais o autor dialogava. Essas prerrogativas, ao mesmo tempo em que condenavam e excluíam qualquer possibilidade de escravismo, eram capazes de legitimar que povos não-brancos, nesse caso os índios, para além de serem convertidos ao cristianismo e aos modos ditos civilizados, fossem utilizados como força de trabalho em benefício dos brancos, ou daqueles que se identificassem com o arcabouço estético-econômico das elites luso-americanas, autorreferenciadas como inaptas ao trabalho braçal. Isto é, manter os índios livres, catequizá-los e introduzilos ao trabalho poderia ser a chave para resolver aqueles três problemas com os quais Januário, o Instituto e a dita boa sociedade, se deparavam. Há um trecho em que ficam nítidos o diagnóstico e as expectativas do Cônego a respeito de índios e negros, trecho que ainda deixa entrever seu entendimento sobre a distância moral que os separava dos brancos, observemos:

(...) se forem bem tratados [refere-se aos índios], cumprindo-se fielmente as convenções, que com eles se fizerem. Se forem docemente chamados a um comércio vantajoso e a uma comunicação civilizadora, teremos, se não nos que hoje existem habituados a sua vida nômade, ao menos em seus filhos e em seus netos, uma classe trabalhadora, que nos dispense a dos africanos. ${ }^{418}$ (grifos meus)

Do trecho grifado se pode depreender, sem muita dificuldade, aquilo que já sinalizamos em relação ao distanciamento moral que os grupos identificados como brancos, ou mesmo os miscigenados a eles associados, conservavam em relação ao trabalho físico, sobretudo o exercido nas lavouras e no ambiente doméstico. ${ }^{419}$ Aqui uma alusão ao título da obra de Todorov, Nós e os outros,${ }^{420}$ parece apropriado: o sujeito oculto que precede ao teremos que grifamos no texto de Januário remete

\footnotetext{
418 Januário da Cunha Barbosa. Programa Se a introdução dos africanos no Brasil serve de embaraço à civilização dos índios, cujo trabalho lhes foi dispensado pelo dos escravos. Neste caso, qual é o prejuizo da lavoura brasileira entregue exclusivamente aos cativos? RIHGB, (1), 1839, p.128.

${ }^{419}$ Há de se apontar uma questão de gênero relevante presente neste ponto: o trabalho exercido na esfera doméstica recaía majoritariamente sobre as mulheres. Mas as mulheres brancas de famílias abastadas jamais se colocariam como sujeitas desse trabalho, assim como os homens brancos jamais se perceberiam como sujeitos do extenuante trabalho nas lavouras. No Brasil, tais afazeres eram - e em alguma medida ainda são - entendidos como ocupações destinadas a pessoas de pele não-branca, entendimento que se perpetua no inconsciente coletivo e na realidade cotidiana através da conservação do abismo social que, em muitos níveis, permite que mulheres e homens de pele nãobranca continuem a aceitar baixas remunerações como recompensa pelos trabalhos braçais que as classes médias e altas, não por acaso ainda predominantemente brancas, se recusam a fazer. Sobre isso, ver: HEBRARD, Jean. \& SCOTT Rebecca J. Provas de Liberdade: uma odisseia atlântica na era da emancipação. SP: Editora UNICAMP, 2014.

${ }^{420}$ TODOROV, Tzvetan. Nós e os outros: a reflexão francesa sobre a diversidade humana. Rio de Janeiro: Jorge Zahar Ed., 1993.
} 
não apenas ao Instituto, mas a todos os que se identificavam com esse lugar social encarnado pelas elites brancas. Toda essa boa sociedade, amparada por amplas camadas de versáteis discursos racialistas ressignificados e perpetuados pela ciência, pela filosofia e pela religiosidade europeias, viam em índios e negros os seus outros: outros na aparência, no comportamento e na aptidão para o trabalho. Essa alteridade não se manifestava em termos de diversidade, ou de relativismo cultural, obviamente. Mas sim em termos hierárquicos. Compreensão esta que, para além da indubitável noção da superioridade brancaleuropeia em relação aos demais grupos étnicos, manifestava também subníveis hierárquicos correspondentes às nuances entre europeus, mouros, asiáticos, americanos e africanos. ${ }^{421}$ No Brasil do XIX, embora essas variações tenham constituído um amplo e complexo mosaico de cores, ${ }^{422}$ os letrados atuantes na política, na imprensa, na Literatura e no IHGB pareciam mais preferir lidar com noções estanques do que compreendiam como raça, do que com a complexidade étnica mencionada. Isto é, na urgência de resolverem questões práticas, de ordem macro, como a própria questão da mão-deobra, reduziam a população habitante do Brasil a três grupos, aos quais se referiam como: nós -brancos- e eles -índios e negros/africanos. O trecho a seguir da dissertação de Januário ilustra bem essa retórica que, para além de inferiorizar índios e negros, expõe a preferência da branquitude luso-americana pelos índios aos negros:

A necessidade de trabalhadores obrigaria os fazendeiros a ser mais humanos com os índios livres, se lhes não tivesse sido fácil comprar negros para os substituir em suas lavouras. Os negros, portanto, servem de embaraço à civilização dos índios; e o que mais é, servem não pouco de retardar a nossa própria civilização. ${ }^{423}$ (grifo meu)

Ora, o texto vai além de sinalizar uma preferência subjetiva em relação aos índios: ele, de fato, defende não só a capacidade física deles para substituir os africanos, como afirma a dispensabilidade desses últimos, conforme grifado na citação anterior a esta. Ou seja: se era inevitável que houvesse um grande

\footnotetext{
${ }^{421}$ BETHENCOURT, Francisco. Racismos: das Cruzadas ao século XX. São Paulo: Companhia das Letras, 2018.

${ }^{422}$ LIMA, Ivana Stolze. Cores, marcas e falas. Sentidos de mestiçagem no Império do Brasil. Rio de Janeiro: Arquivo Nacional, 2003.

${ }^{423}$ Januário da Cunha Barbosa. Programa Se a introdução dos africanos no Brasil serve de embaraço à civilização dos índios, cujo trabalho thes foi dispensado pelo dos escravos. Neste caso, qual é o prejuizo da lavoura brasileira entregue exclusivamente aos cativos? RIHGB, (1), 1839, p.128.
} 
contingente de pessoas destinadas ao que entendiam como mão-de-obra, que fossem os índios, já que "os pobres negros, fora de seu país natal, são menos aptos aos nossos trabalhos do que os índios." ${ }^{424}$ Aqui se entrecruzam dois aspectos já trabalhados no decorrer desta tese: 1) a compreensão das elites crioulas iberoamericanas de que os povos originários das Américas, embora considerados inferiores aos europeus, seriam ainda superiores aos originários de África, o que, na verdade, constitui, como já ponderamos, uma apropriação operada por essa branquitude letrada luso-americana da longa tradição de hierarquização dos povos; 2) o entendimento, já compartilhado pelo senso-comum e selado na construção da subjetividade nacional pelo Romantismo, de que os africanos não pertenciam ao Brasil, porque estrangeiros. Noção essa que, em acordo com as aspirações branqueadoras da boa sociedade, acabava sendo validada, subjetivamente, aos de pele negra em geral, tanto aos que nasciam no Brasil sob a condição jurídica de escravizado, como aos que conseguiam conquistar a liberdade depois de adultos. Isto é, no nível mais objetivo do discurso, o significado de africano era imediatamente associado ao que se entendia por escravo. Já, em uma camada menos óbvia do discurso, mas nem por isso menos evidente, todos aqueles e aquelas que possuíssem características físicas que os identificassem ao que se convencionou chamar africano sofreriam os efeitos do nefasto legado dos colonizadores europeus sobre tudo o que significava ter a pele negra. Dentro dessa categoria, a dos negros nascidos no Brasil sobre os quais incidiam, analogamente, toda a gama de concepções pejorativas atribuídas aos africanos, há pelo menos dois grupos: o dos que nasciam escravos, condição que pressupunha automaticamente a impossibilidade de tornar-se cidadão no Brasil independente, o que lhe impunha uma espécie de vácuo de pertencimento, já que não era identificado como africano e nem era considerado brasileiro; e o dos que nasciam livres, ou tornavam-se livres, estatuto que não garantia a plena cidadania, mas a colocava como uma possiblidade se, e somente se, este sujeito negro ou mestiço recebesse ou conquistasse bens imóveis. De todo modo, embora alguns pretos livres ou libertos tenham conseguido furar as barreiras estruturais que os restringiam ao universo do trabalho braçal - ou

\footnotetext{
${ }^{424}$ Januário da Cunha Barbosa. Programa Se a introdução dos africanos no Brasil serve de embaraço à civilização dos índios, cujo trabalho lhes foi dispensado pelo dos escravos. Neste caso, qual é o prejuízo da lavoura brasileira entregue exclusivamente aos cativos? RIHGB, (1), 1839, p.128.
} 
por serem filhos de relações interraciais e receberem o investimento do pai branco em sua educação, ou por terem conquistado por meios próprios os cabedais necessários ao financiamento de sua ascensão material e intelectual -, pesava sobre todos os negros, fossem eles africanos, crioulos escravizados, crioulos livres, ou mestiços livres o fardo do imaginário de inferioridade construído sobre seu tom de pele, tal qual podemos verificar no trecho já citado do texto de Januário no qual afirma, sintomaticamente, que não os africanos ou os escravos, mas os negros embaraçavam a civilização dos índios e retardavam a nossa [dos brancos] própria civilização.

A publicação desse texto, assinado pelo Secretário Perpétuo, no primeiro tomo da Revista do IHGB tem um significado importante nesse contexto de definições que se desdobrou a partir da Lei de 1831. Ele expressa a assunção de uma postura condenatória da escravidão por parte do Instituto. E mais, expressa, através de uma proposta de substituição da mão-de-obra africana, a chancela do Instituto a um projeto civilizatório de integração gradual dos índios, destinandolhes o lugar de classe trabalhadora. Embora essa não fosse uma opinião unânime no Instituto, ela era endossada, por exemplo, pelos Românticos da Nitheroy que, recém chegados ao Brasil, trataram logo de se associar ao Instituto. A aproximação entre a retórica do Romantismo enunciada pela Nitheroy e a retórica de Januário chancelada pela Revista do IHGB é evidente: alijar o negro o tanto quanto fosse possível do pertencimento nacional, mitificar o índio anterior ao colonizador e incorporar os índios sobreviventes - desde que catequizados, civilizados e submetidos - ao projeto de Estado-nação branco que representava os interesses materiais e morais desses sujeitos que convergiam suas ideias em torno desse discurso caracterizado pela dupla face do liberalismo moderado do Brasil oitocentista, um discurso simultaneamente antiescravista e racialista.

Não obstante, é hora de lembrar que um grupo alheio a essa perspectiva adquiria, nesse limiar da década de 1840, cada vez mais legitimidade política: aqueles identificados como Regressistas. Liderados pela força retórica de Bernardo Pereira de Vasconcelos e impulsionados pelo crescimento da economia cafeeira no Vale do Paraíba, eles reuniam suas forças no sentido de manter a desigualdade jurídica entre os diferentes grupos étnicos habitantes do país. Assim, na contramão do que defendiam os redatores da Nitheroy e os sócios do IHGB aliados de Januário da Cunha Barbosa, os partidários de Vasconcelos se encarregariam de reafirmar a 
escravidão de africanos e de seus descendentes aqui nascidos, argumentando que a prática contribuiria para a civilização do país. ${ }^{425}$ Isto é, para a civilização do país de senhores brancos.

\subsection{0 enredo nacional e a atualização da retórica racialista}

Se até aqui tivermos conseguido sugerir que toda a estruturação política, jurídica, filosófica, teológica e científica articuladas desde a expansão ultramarina pelos europeus, e tidas como padrão, na realidade, expressavam a verdade não do todo, mas de uma parcela, capaz de convencer a si e aos seus outros de sua superioridade, talvez consigamos demonstrar que a implantação do Estado-nação na vaga aberta pela crise do Antigo Regime, assim como a própria formulação disciplinar da História, também corresponderam a construções parciais, embora se pretendessem totais.

Pois, as discussões que tiveram lugar no IHGB sobre a definição das verdadeiras épocas da História do Brasil ${ }^{426}$ dão a ver o raio que a narrativa retrospectiva de um Brasil inventado há pouco mais de uma década deveria alcançar. O raio, no sentido espacial, alcançava todos os territórios convertidos em províncias do Império, o que demandaria um grande esforço não apenas para mapear toda essa diversidade, como também para convertê-la em unidade. Daí toda a tensão entre os sócios que defendiam a imediata dedicação à escrita da história geral, tal qual incentivava Januário da Cunha Barbosa, e aqueles que alertavam sobre a necessidade de um esforço de escrita das várias histórias provinciais, como pré-requisito a uma tessitura - como chamavam - filosófica da história. ${ }^{427}$ Isto é,

\footnotetext{
${ }^{425}$ Bernardo Pereira de Vasconcelos. Discurso na Câmara dos Deputados, sessão de 25 de abril de 1843. In: CARVALHO, José Murilo (org.) Bernardo Pereira de Vasconcelos (1795-1850). São Paulo: Editora 34, 1999, p.268.

${ }^{426}$ Na primeira sessão ordinária do Instituto, no dia 1/12/1838, Januário da Cunha Barbosa propôs o que seria o primeiro programa histórico do Instituto, formulado da seguinte maneira: "Determinarse as verdadeiras épocas da História do Brasil, e se esta se deve dividir em antiga e moderna, ou quais devem ser suas divisões" RIHGB (I), 1839, p.45.

${ }^{427}$ De acordo com as atas das primeiras sessões ordinárias do Instituto é possível acompanhar a intensidade dos debates acerca da querela entre os partidários da História Geral e os defensores das Histórias Provinciais. A partir do que apurei por ocasião da pesquisa de mestrado dedicada aos programas históricos, tudo indica que a falta de consenso em relação a esta questão - em torno da qual estavam polarizados de um lado o Secretário perpétuo e fundador Januário da Cunha Barbosa e de outro o Presidente Visconde de São Leopoldo e o Vice Cunha Mattos - fez com que a dissertação redigida e apresentada à plenária do IHGB por Cunha Mattos, nos primeiros meses de
} 
uma narrativa que criasse um passado comum a todas as províncias, ou melhor, que produzisse um sentido de unidade, uma História do Brasil. Devir esse, cabe ressaltar, expressivo dos anseios dos letrados da Corte, daqueles adeptos da ideia de Império do Brasil pela via de um centralismo político que se irradiava do Rio de Janeiro para as demais províncias. Ou melhor, História Geral do Brasil que, por se constituir como uma narrativa afirmativa do projeto de Brasil desses sujeitos, acabaria, obviamente, por minimizar ou mesmo silenciar as possibilidades de configuração de novos Estados a partir dos territórios que haviam determinado como províncias, convertendo-os, pela lente do centralismo emanado da Corte, em meros movimentos separatistas. ${ }^{428}$ De todo modo, mesmo entre os sujeitos que falavam desse lugar, o das vozes do Império do Brasil sediado no Rio de Janeiro e afiançado pelo Instituto Histórico e Geográfico - não à toa autorreferenciado como Brasileiro -, havia nomes de peso que faziam ressalvas relativas às dificuldades práticas de se realizar a escrita da dita história geral. Entre eles estavam o do próprio Presidente do Instituto, José Feliciano Fernandes Pinheiro (Visconde de São Leopoldo), e Raimundo José da Cunha Mattos - sócio fundador e vice-presidente, que acerca das ditas adversidades ponderava:

(...) O Exmo. Sr. Visconde de São Leopoldo, ferindo com mão de mestre o complexo dos argumentos mostrou, e parece-me que mui bem, que por hora não estamos habilitados a escrever a História Geral do Império do Brasil, por nos faltarem muitos elementos Provinciais para isso necessários - Felizmente o Exmo. Sr. Visconde de São Leopoldo faz honra a minha opinião, quando quer que indaguemos em primeiro lugar a História particular ou das Províncias, para com bons materiais escrevermos a História Geral do Império Brasileiro. ${ }^{429}$ (os grifos correspondem ao original)

1839, em reposta ao programa histórico relativo às épocas, só ganhasse as páginas da Revista do IHGB - com indícios de censura - na edição de 1863, quando todos os nomes envolvidos na polêmica já haviam deixado este mundo. A esse respeito ver: DIAS, Fabiana Rodrigues. Por entre legados e demandas: um estudo sobre os programas históricos do IHGB (1838-1856). Dissertação de Mestrado, PPGH -UERJ, 2009, p.90-6.

${ }^{428}$ Como bem lembrou Ilmar Rohloff de Mattos, a ideia de província remete à ideia de território conquistado, subjugado aos interesses e ao controle de um poder que emana de um centro, o que ajuda a compreender não só o uso do termo pela Corte para se referir aos territórios sob sua jurisdição, como colabora para a problematização da tão naturalizada abordagem no imaginário social de que o único projeto legítimo de Estado era o gestado no Rio de Janeiro. A esse respeito, ver: MATTOS, Ilmar Rohloff. Transmigrar - nove notas a propósito do Império do Brasil. In: PAMPLONA, Marco A. \& STUVEN, Ana Maria (orgs.). Estado e Nação no Brasil e no Chile ao longo do século XIX. Rio de Janeiro, Garamond, 2010. Ver também: MELLO, Evaldo Cabral de Melo, A outra independência: o federalismo republicano de 1817 a 1824. São Paulo: Editora 34, 2004.

${ }^{429}$ Raymundo José da Cunha Mattos. Dissertação acerca do sistema de se escrever a história antiga e moderna do império do Brasil. RIHGB (XXVI), 1863, p.122. 
A discussão sobre as épocas acabaria desdobrando outras questões para além dessa relativa aos impasses em torno da escrita de uma História do Brasil que resultasse de um esforço institucional. Uma delas - e talvez a mais importante no que tange a nossas investigações - guarda relação com o consenso do IHGB de que o primeiro capítulo da História do Império do Brasil corresponderia à época dos aborígenes ou autóctones. A ela se seguiriam a época do descobrimento pelos portugueses e da administração colonial e a terceira e última época que abrangeria "todos os acontecimentos nacionais desde o dia em que o povo brasileiro se constituiu soberano e independente e abraçou um sistema de governo imperial, hereditário, constitucional e representativo". ${ }^{430}$ Por mais que a segunda e terceira épocas sinalizassem que haveria dificuldades em reunir tamanha gama de documentos e memórias até então depositados cada qual em sua localidade de origem, a primeira época despertava uma inquietação ainda maior, uma inquietação relacionada à ausência do que constituía, e de alguma maneira ainda constitui, o cerne da História: o reconhecimento de uma trajetória civilizacional. ${ }^{431}$

Não por acaso, os sócios do IHGB incentivariam uma série de expedições que se propusessem a verificar notícias ou mesmo lendas sobre possíveis ruínas civilizacionais encravadas em florestas então pertencentes ao Império do Brasil. ${ }^{432}$ A busca por vestígios de civilizações indígenas que tivessem antecedido à presença do colonizador português equivalia, com efeito, à busca pela legitimidade histórica desses povos originais do território, a essa altura, aliás, já homogeneizados e convertidos, pelos primeiros românticos, na alegoria do brasileiro original. Como que orientados pelo propósito de comprovar documentalmente o status

\footnotetext{
${ }^{430} \mathrm{Na}$ dissertação na qual desenvolve o programa sobre as épocas, Cunha Mattos diz abraçar “(...) de boa vontade a opinião do ilustre Secretário Perpétuo [Januário da Cunha Barbosa] acerca da divisão das épocas da História do Brasil", ao que complementa enumerando as três épocas e seus respectivos marcos. RIHGB (XXVI), 1863, p.129.

431 Aqui penso na associação, quase que inconscientemente reiterada pelos historiadores, entre História e Civilização. Associação esta que nos provoca a pensar sobre o lugar - ou não-lugar - dos povos considerados não-civilizados na História, ou ainda na História como lugar cativo dos civilizados, isto é, dos povos autorreferenciados como brancos. Logo me ocorre a canônica coleção coordenada por Sergio Buarque de Holanda - e posteriormente por Boris Fausto - nos idos dos anos 1960, sob o sintomático título História Geral da Civilização Brasileira (HGCB), assim como me ocorre a delimitação do campo da Antropologia nas primeiras décadas do século XX, como que acompanhando a tendência do culturalismo, reconhecendo as alteridades ao que se entendia por civilização, mas sem conseguir romper com a estrutura que, em última instância, reiterava a História como o espaço narrativo da branquitude civilizada.

${ }^{432}$ Constitui exemplo deste anseio, o programa histórico proposto pelo Desembargador Pontes na sessão do dia 06/04/1839 intitulado pela seguinte indagação: "Quais são os vestígios existentes no Brasil, que possam provar uma civilização anterior à conquista dos portugueses?” RIHGB (1), 1839.
} 
civilizacional dos índios do Brasil, o IHGB criou uma sessão dedicada ao estudo dessa alteridade da História que, por analogia, era também alteridade ao protagonismo branco/colonizador dessa mesma narrativa: a seção de Arqueologia e Etnografia. ${ }^{433}$ Não que a comprovação de indícios civilizacionais dos índios do Brasil fosse algo capaz de os alçar ao mesmo patamar dos colonizadores na narrativa da trajetória pátria, mesmo porque, caso tais vestígios tivessem sido identificados e submetidos à crítica, eles serviriam mais para conferir status ao protonacionalismo que o grupo da Nitheroy e o de Januário pretendiam emplacar, do que propriamente ao reconhecimento efetivo desses povos como sujeitos da História. Basta lembrar como até os dias atuais são tratados os impérios Inca e Asteca por grande parte dos manuais de História da educação básica. Mesmo tendo suas experiências de vida em comunidade chanceladas pela régua civilizacional da narrativa produzida pelo colonizador/branco/europeu - leia-se pela História - como experiências civilizadas, elas continuam a ser nomeadas civilizações précolombianas. Isto é, uma civilização outra que não a inaugurada por Colombo. A hierarquia entre o colonizador/branco/europeu narrador da História e suas principais alteridades no mundo ibérico - o índio e o negro - haveria de ser, embora nuançada, sempre preservada, tal como, aliás, já faziam os viajantes quando enalteciam a diferença da paisagem e do clima do Novo Mundo, mas não deixavam de reiterar a inferiorização de seus habitantes não-brancos.

Não por acaso, na seção de Etnografia o objetivo era o de formar um arquivo paralelo ao da seção de História, dedicado a reunir tudo o que fosse possível em termos de elementos comprobatórios da existência dos índios, de modo que se tornasse possível averiguar esses vestígios com os mais recentes critérios metodológicos que começavam a definir a disciplinarização das áreas do conhecimento. ${ }^{434}$ A partir do exercício de crítica desses elementos, que passavam, então, a ser vistos como documentos históricos, lhes caberia a tarefa de alinhavar uma narrativa verossímil e nacionalizante desse outro interpretado como simulacro do exotismo ou, quando convinha, da autenticidade. O papel da seção de Etnografia

\footnotetext{
${ }^{433} \mathrm{O}$ trabalho de doutoramento de Kaori Kodama foi essencial para desenvolvermos as reflexões aqui apresentadas, principalmente porque já reconhece na criação da seção de Etnografia do IHGB uma função acessória ao propósito maior do Instituto: a escrita da dita História Geral. Ver: KODAMA, kaori. Os índios no Império do Brasil: a etnografia do IHGB entre as décadas de 1840 e 1860. Rio de Janeiro: FIOCRUZ; São Paulo: EDUSP, 2009.

${ }^{434}$ IGGERS, Georg. Historiography in the Twentieth Century. From objjectivity to the postmodern challenge. Hanover-London, Wesleyan University Press, 1997, p. 27.
} 
dentro da estrutura do Instituto seria, com efeito, o de auxiliar à escrita da História Geral, fundamentando essa que seria a primeira época - e acessória - ao que entendiam como sendo a narrativa principal, qual seja, a iniciada a partir da presença do elemento civilizado - branco - no território que viria a se tornar Brasil. No que diz respeito a esse esforço do Instituto em tentar encaixar na diacronia inventada do Estado-nação a diversidade dos povos americanos, Cunha Mattos confessava: "se eu houvesse de escrever a história dos aborígenes do Brasil, verme-ia tão embaraçado como todos os que em épocas mais ou menos remotas tem dissertado a respeito deles." ${ }^{435}$ Um desafio que se ampliava, à medida que se apresentavam os obstáculos inerentes à pretensa incorporação das plurais tradições dos povos americanos - regidas pela noção de tempo cíclico, profundamente conectado com o tempo da natureza- pela lógica historicista, ou lógica do tempo linear, a qual se associava a noção de que a submissão da natureza à humanidade garantiria o progresso, o lucro e, em última instância, a conquista dos patamares civilizatórios. Talvez se deva mesmo a essa insolúvel inadequação, a observação de Cunha Mattos no sentido de lamentar, a partir de seu olhar herdeiro do colonialismo, que “(...) as tradições entre os índios são mui confusas e disparatadas." 436

Parece óbvia, portanto, a preocupação em recuperar elementos capazes de tornar exequível a empreitada de escrita daquela que o Instituto convencionou definir como primeira época da História Geral do Império do Brasil. Pois, ainda que seu papel fosse coadjuvante em relação ao das duas épocas subsequentes, e que sua operação coubesse a uma sessão que não a de História, se costurou no IHGB um consenso em relação a sua indispensabilidade. De modo muito semelhante ao qual foram tratados pelos românticos da Nitheroy, os índios são então aproveitados por essa operação historiográfica de pretensão nacional como sujeitos da essência de um Brasil ancestral que, embora vilipendiado pela ambição dos colonizadores, teria recobrado sua potência original após a independência. Esse é o lugar que

\footnotetext{
${ }^{435} \mathrm{O}$ grifo é nosso e tem o intuito de marcar a relação de alteridade implícita na referência a uma História que não é a nossa, mas a deles. Ao que Cunha Mattos se refere como nossa História, sugerimos que se leia como narrativa do branco/civilizado, a qual o autor pertence como sujeito e o Instituto como fiador. RIHGB (XXVI), 1863, p.133.

${ }^{436}$ Raymundo José da Cunha Mattos. Dissertação acerca do sistema de se escrever a história antiga e moderna do império do Brasil. RIHGB (XXVI), 1863.
} 
conferem no rascunhar da História Geral do Império do Brasil à representação de índio que constroem. Mas e o negro? Qual seria o seu lugar nessa narrativa?

De antemão, talvez seja importante dizer que não houve contemplação das tradições de origem africana, ou de suas ressignificações na América portuguesa por qualquer seção do Instituto, o que denota um tratamento distinto, portanto, daquele dispensado ao passado dos povos indígenas. Posto isso, se pensarmos essa História de contornos nacionais, visceralmente ligada à chancela do Estado-nação oitocentista - ao mesmo tempo crítica e herdeira do colonialismo- como lugar narrativo da tradição branca/ europeia, avançaremos em direção à compreensão de que ela constitui mais uma das verdades forjadas na esteira das quase que onipresentes camadas discursivas legitimadoras da superioridade física e intelectual dos brancos. Com efeito, o raio moral dessa História cumpria o propósito de alcançar a todos os habitantes do Império, mas produzia diferentes sensações de pertencimento, então matizadas por uma complexa relação entre fenótipo, origem e condição jurídica. Afinal, a associação entre cor da pele e cidadania não era óbvia, mas sutil, já que a Constituição não definia os cidadãos brasileiros por critérios raciais, mas sim por seu estatuto de liberdade, o que evidentemente interditava o acesso à parte considerável dos negros - os escravizados. ${ }^{437}$ No entanto, a cidadania se estendia, guardadas todas as outras dimensões de inferiorização, aos negros que conseguissem conquistar a liberdade por meio da alforria ${ }^{438}$ e aos pardos nascidos livres em função do reconhecimento de sua ascendência branca, normalmente atestada pelo lado paterno. ${ }^{439}$

Em que pesem os inúmeros estudos de caso que extrapolem essa formulação de pretensão mais geral, as disputas em torno da escrita da História que tiveram lugar no IHGB dos primeiros anos pareciam sugerir que a retórica de maior ressonância nesse momento era aquela que defendia um roteiro protagonizado pela boa sociedade - política e intelectualmente emancipada do jugo colonizador - e

\footnotetext{
${ }^{437}$ PARRON, Tamis Peixoto. A política da escravidão no Império do Brasil (1826-1865). SP: Civilização Brasileira, 2011, p.26-7.

${ }^{438}$ É imenso o leque de estudos competentemente elaborados acerca dos mecanismos criados pelos escravizados para romperem com o status de servidão que definia sua existência. As brechas encontradas por muitos deles para utilizarem o próprio sistema jurídico configurado pelos interesses da branquitude civilizada em benefício de sua luta por liberdade são objeto do interessante trabalho de keila Grinberg. Ver: GRINBERG, Keila, $O$ fiador dos brasileiros- cidadania, escravidão $e$ direito civil no tempo de Antonio Pereira Rebouças, Rio de Janeiro: Civilização Brasileira, 2002.

${ }^{439}$ No que concerne às disputas em torno dos direitos civis e políticos concedidos e/ou conquistados pelos que eram identificados como pretos livres, pretos alforriados, ou pardos, ver: MATTOS, Hebe Maria. Escravidão e cidadania no Brasil monárquico. 2 ed. Rio de Janeiro, Jorge Zahar, 2004.
} 
coadjuvado pelo índio, retrospectivamente idealizado como manifestação da virtude brasileira e, no presente, pensado como potencial elemento substituidor da mão-de-obra de africanos e crioulos escravizados. Assim, a boa sociedade representada no IHGB corroborava a invisibilidade do negro na retórica de pretensões nacionais e, ao mesmo tempo, endossava as impressões correntes de que, em função de uma suposta ausência do índio contemporâneo do ambiente urbano/ dito civilizado, haveria de se atuar na conversão dos que chamavam de filhos das brenhas, resolvendo, desse modo, indiretamente, uma questão de suma importância ao Estado que representavam, a da posse sobre os territórios originalmente pertencentes a esses povos. Ademais, esses debates travados no IHGB sob a égide da escrita da história pátria estavam ainda atravessados por duas outras pautas correlatas: a do provável aumento das restrições em relação ao tráfico de africanos; e a da necessidade, decorrente da própria diminuição da entrada de novos escravos, de se pensar uma transição do modelo escravocrata ancorado na racialização dos africanos para um outro similar, que fosse capaz de recrutar, converter e submeter os índios ao trabalho, sem que fossem - diziam os civilizados - propriamente escravizados. Movimento que, se levado adiante, contribuiria, convenientemente, para estancar a presença negra no Brasil, forjando uma ideia de brasileiro afinada às concepções racialistas luso-americanas que preferiam o índio ao negro. Isto é, que toleravam o elemento indígena na composição étnica do que idealizavam como brasileiro, mas que relutavam em admitir o legado africano nessa composição.

De todo modo, na impossibilidade prática de eliminar o negro e civilizar o índio para utilizá-los em seu lugar, o que parecia se sedimentar era a noção de que a História do Brasil conferiria aos de ascendência ibérica o pertencimento pleno e, aos demais, o recado subliminar de que sua integração dependeria de sua aproximação - moral e fenotípica - dos parâmetros da branquitude civilizada. A esses habitantes de pele não-branca do território convertido em Império do Brasil, expropriados de suas formas plurais de pertencimento, inferiorizados na dinâmica de definição do Estado e, em última instância, esvaziados de sua humanidade por séculos de trabalhos forçados, miscigenar-se, não apenas física como moralmente, podia significar, então, aproximar-se daquilo que se apresentava como padrão, ou como universal. Podia, ainda, constituir uma espécie de oportunidade de acesso à cidadania e, em última instância, à História do Brasil. Gerar nesses contingentes não-brancos o anseio por liberdade, por reconhecimento, por pertencer estética e 
intelectualmente ao Brasil independente e civilizado, constituía uma das principais estratégias da dita boa sociedade branca e civilizada para alimentar o imaginário de coesão nacional, mantendo sempre vivo nos grupos racialmente inferiorizados o desejo duplo - e mesmo indissociável - por tornar-se livre e por perceber-se brasileiro.

No que tange aos horizontes que o XIX inaugurou para esses grupos racialmente inferiorizados, sobretudo a partir do encerramento do tráfico atlântico, se faz pertinente pensar, a partir de Achille Mbembe, em como o discurso ocidental, dito universal, testemunhou a abertura de três possibilidades para o enquadramento do negro - potencialmente liberado do escravismo - no mundo orquestrado pela branquitude ${ }^{440}$ Nos seus termos, “a noção de 'civilização' (...) autorizava [1] a distinção entre o humano e aquilo que não o é de modo nenhum, [2] ou não o é o bastante ainda, [3] mas que pode se tornar humano mediante um adestramento adequado." ${ }^{441}$ Corresponde a isso a aceitação cada vez mais frequente de que os grupos étnicos considerados inferiores seriam passíveis de aperfeiçoamento, desde que se colocassem disponíveis para serem adestrados. Conforme temos discorrido, pelo menos desde o XVIII, sobretudo a partir das contribuições de Buffon, vinha se desdobrando essa ideia de que embora fossem todos humanos, dentro da espécie havia variações que refletiam os diferentes ambientes, as migrações e as miscigenações em geral. O reconhecimento de que, independente das diferenças, todas as raças seriam humanas fez cair em desuso a ideia de que algumas delas sobretudo as não-brancas - teriam se degenerado com o tempo e se distanciado do que se convencionou definir como a humanidade. É como se a noção da perfeita criação divina - que remetia à origem única dos seres humanos e à degeneração irreversível de alguns deles - fosse cedendo espaço à perspectiva de que os humanos foram se definindo e se diferenciando no tempo e no espaço. ${ }^{442}$ Ocorre que, a partir de meados do XIX, se acopla a essa possibilidade da ação civilizatória

\footnotetext{
${ }^{440}$ Aqui cabe recuperar a discussão sobre a desumanização do negro e, em um grau talvez atenuado, a desumanização também do índio americano e, quiçá, de todos os demais povos colonizados, uma vez que tudo o que orbitava em torno da ideia de humanidade, bem como toda a sua encarnação material, estava, ou talvez ainda esteja, associado às conquistas, ao desenvolvimento, enfim, ao que a ideia de civilização ocidental representava/ representa. Nesse sentido, Achille Mbembe coloca a seguinte provocação: "era possível encontrar neles também a mesma humanidade, apenas dissimulada sob designações e figuras diferentes?” MBEMBE, Achille. Crítica da razão negra. n1 Edições, 2018, p.154.

${ }^{441}$ Ibid., p.158.

${ }^{442}$ BETHENCOURT, Francisco. Racismos: das Cruzadas ao século XX. São Paulo: Companhia das Letras, 2018, p. 342.
} 
como instrumento de aperfeiçoamento dos supostamente inferiores, uma nova função para esse devir civilizatório: colocar-se a serviço do arranjo dos Estadosnação. Ou seja, a ação civilizatória, para além de contribuir para a adequação moral de populações consideradas atrasadas, ou mesmo selvagens, demonstraria ser instrumento indispensável à equalização das diferenças, regulando, o quanto fosse possível, o compartilhamento de parâmetros comuns de convivência entre os que se consideravam sujeitos civilizados e aqueles que esses mesmos sujeitos pretendiam civilizar, mas sem que com isso fossem comprometidas as noções de hierarquia que os diferenciavam.

Cabe observar, que as disputas travadas pelos letrados do IHGB em função da escrita de uma história pátria correspondiam ao crescente uso cotidiano que o termo Geschichte vinha adquirindo como expressão de uma nova forma de relatar o passado. Expressão essa que, por sua vez, traduzia os desígnios de uma nova ordem que, paulatinamente, adentrava o mundo estamental, erguendo a bandeira das singularizações e fazendo, por exemplo, das pátrias, A pátria. A histoire dos acontecimentos narrados sob o signo da cronologia perdia seu espaço, à medida em que o modo Geschichte de narrar o passado passava a abarcar a coletividade dos acontecimentos como parte integrante de um mesmo sistema, no qual imbricavamse causas e efeitos de unidades, a priori, desvinculadas espacial e temporalmente. ${ }^{443}$ Nesse movimento, não apenas o negro como também o índio passaram a constituir um dilema para os maiores interessados nessa reordenação. Afinal, como integrálos? Como diluí-los? Ou mesmo, como apagá-los para que se produzisse uma unidade nacional/racial? Manuela Carneiro da Cunha, ao discorrer sobre as articulações em torno da política indigenista no Brasil do XIX - mais precisamente até a década de 1860 -, é precisa em afirmar que havia menos uma preocupação em relação aos fins, ou aos objetivos de longo prazo, e mais em relação aos meios de se resolver o que consideravam um problema: a presença dos índios que insistiam em existir. De modo similar à observação de Mbembe a respeito das possibilidades do negro em um mundo que nacionalizava a raça e, ao mesmo tempo, racializava

\footnotetext{
${ }^{443} \mathrm{O}$ capítulo 2 da tese de doutoramento de kaori Kodama trabalha justamente o movimento de formação da nação a partir da diluição das nações - no sentido antigo do termo- em um caldo único, aparentemente consistente. Ver: KODAMA, kaori. Os índios no Império do Brasil: a etnografia do IHGB entre as décadas de 1840 e 1860. Rio de Janeiro: FIOCRUZ; São Paulo: EDUSP, 2009. No que tange a tal reordenação imposta pela modernidade ao narrar o passado se faz indispensável citar Koselleck. Ver: KOSELLECK, Reinhart. Futuro Passado: contribuição à semântica dos tempos históricos. Rio de Janeiro: Contraponto: PUC-Rio, 2006.
} 
a nação ${ }^{444}$ Manuela Carneiro da Cunha identifica as alternativas consideradas pela boa sociedade do Brasil quando discutia o que fazer com os povos originários: “(...) exterminar sumariamente (...), distribuí-los aos moradores, ou se deviam ser cativados com brandura." 445

O IHGB como um dos espaços de debate criado e ocupado por essa boa sociedade - ou pelo menos por parte dela - sediou, como já antecipamos, importantes discussões relativas à questão do uso pragmático da mão-de-obra de índios e de negros, assim como do lugar - ou não-lugar - destinado a cada qual na História do Brasil. Os sinais emitidos pelo Instituto acerca da abordagem a ser dispensada aos habitantes de pele não-branca ressoavam nas esferas decisórias de poder, assim como eram também determinados pelas demandas de ordem mais prática que dessas esferas emanavam, sobretudo porque, nesses espaços, circulavam os mesmos sujeitos, ora protagonistas da ação política, ora dublês de intelectuais. Em função das disputas epistemológicas que se colocavam e das atualizações cotidianas que o assunto exigia, a encruzilhada para a qual convergiam os temas da escrita da História Geral e o do delinear da nação brasileira, acabou se tornando objeto de um concurso dedicado a premiar quem enviasse, até o final do ano de 1842, o melhor Plano de se escrever a história antiga e moderna do Império do Brasil, organizada com tal sistema que nela se compreendam as suas partes política, civil, eclesiástica e literária.

Pois em 10 de janeiro de 1843, Karl Friedrich Phillip von Martius assinou e datou de Munich um texto intitulado Como se deve escrever a História do Brasil. Este von Martius era o mesmo viajante-naturalista-botânico que na década de 1820 havia percorrido o Brasil registrando e descrevendo a paisagem e os habitantes, conjugando deslumbramento e repulsa ${ }^{446} \mathrm{E}$ este seu texto, tornado possível graças a essa sua longa experiência de viagem, parece mesmo ter sido confeccionado com a intenção de atender ao chamado feito pela Revista do Instituto, em 1842, para que fossem enviadas ideias sobre a composição de uma História do Brasil. No entanto,

\footnotetext{
${ }^{444}$ Acerca da intimidade criada entre o conceito de nação e o de raça ao longo do século XIX, bem como o uso das expressões grifadas, ver: MBEMBE, Achille. Crítica da razão negra. n-1 Edições, 2018, p.162.

${ }^{445}$ CUNHA, Manoela Carneiro da. Legislação indigenista do século XIX. São Paulo: EDUSP, 1992, p.5.

${ }^{446}$ A dicotomia aqui grifada é uma alusão a originalmente mencionada no texto de Manoel Luiz Salgado Guimarães sobre a experiência de viagem de Von Martius. Ver: GUIMARÃES, Manoel Luiz Salgado. História e natureza em von Martius: esquadrinhando o Brasil para construir a nação. História, Ciências, Saúde - Manguinhos, vol. VII(2), 389-410, jul.-out. 2000.
} 
essa dissertação de von Martius seria publicada originalmente no número 24 da Revista do Instituto, impressa em janeiro de $1845,{ }^{447}$ sem qualquer menção a ter vencido o concurso anunciado em 1842 e sem qualquer referência a ter recebido a premiação a ele vinculada. Somente na sessão ordinária de 10 de junho de 1847 seria posto em discussão e aprovado o parecer da comissão especial criada para avaliar as memórias concorrentes ao concurso proposto cinco anos antes. ${ }^{448}$ Esse parecer, com data de 20 de maio de 1847 reconhecia que a dissertação vencedora do concurso já estava publicada "há muito na Revista, [em função] de um descuido porque passou a redação (...) sendo a memória dirigida para o concurso: o que todavia lhe devemos relevar, e talvez mesmo agradecer, visto ser o assunto da memória tão transcendente para o Brasil, e aí tão sabiamente explanado." ${ }^{449}$ Apenas em 1847, a partir da discussão e publicação desse parecer, o texto de Von Martius Como se deve escrever a História do Brasil seria oficializado como vencedor do concurso e devidamente premiado, embora já circulasse impresso pela própria Revista do Instituto há pelo menos dois anos. O lapso temporal entre a publicação do texto e o seu reconhecimento como vencedor do concurso corresponde a um período de ampla queda na produtividade dos sócios do Instituto, o que talvez possa ser explicado, em parte, pelo adoecimento e posterior falecimento do Secretário perpétuo Januário da Cunha Barbosa, justamente entre os anos de 1845 e 1846 . A isso teria se somado, ainda em 1846, o afastamento por enfermidade do Presidente do Instituto, José Feliciano Fernandes Pinheiro. Baixas que impediram, inclusive, a realização da tradicional sessão aniversária nesses mesmos anos de 1845 e 1846 e que, muito provavelmente, contribuíram para adiar os ritos de avaliação dos trabalhos apresentados. Fato, no entanto, que não impediu a publicação do texto de Martius, antes mesmo de ter passado pelo crivo da comissão avaliativa designada para o concurso, o que pode refletir não só a gratidão do Instituto em receber um original escrito por um dos mais renomados naturalistas daquele tempo, como também o seu interesse em agregar valor à sua Revista. ${ }^{450}$

\footnotetext{
${ }^{447}$ Apesar de constar na primeira página da dissertação Como se deve escrever a História do Brasil que ela fora publicada em 1845 , no $\mathrm{n}^{\circ} 24$ da Revista, hoje o texto de von Martius encontra-se publicado no Tomo VI da RIHGB, relativo ao ano de 1844. Ver: RIHGB (6), 1844, pp. 381-403.

${ }^{448}$ Os nomes que assinam o dito parecer são: Dr. Francisco Freire Alemão, Monsenhor Joaquim da Silveira e Dr. Thomaz Gomes dos Santos. Ver: RIHGB (9), 1847, pp. 279-287.

${ }^{449}$ RIHGB (9), 1847, p. 279-80.

${ }^{450}$ Conforme analisamos no capítulo 2 desta tese, vale lembrar que a obra $A$ Viagem de autoria de von Martius e von Spix e, especialmente a publicação de Flora Brasilienses de autoria exclusiva do botânico Martius, foram obras de referência ao longo do XIX. A esse respeito, ver: TEIXEIRA,
} 
Apesar do imbróglio em torno da premiação, aqui importa repensar o significado desse texto na diacronia das interpretações definidoras da ideia de Brasil e também da ideia de brasileiro. Sobretudo porque é um texto que produziu uma série de impressões no senso comum em função de ter sido forjado, ao longo do século XX, como pedra angular de uma identidade nacional que se definiria a partir da mescla, como se já ensejasse uma abordagem culturalista. Apropriação que foi sendo realizada, à medida que foram surgindo, no rastro da influência dos Annales, interpretações de Brasil que superavam as noções plantadas pelo positivismo e pelo evolucionismo e pavimentavam o caminho de que o multirracialismo constituía a síntese do Brasil. Assim, as considerações de Martius sobre a mescla foram sendo convertidas em uma espécie de gérmen da interpretação freireana, como se antecipassem a perspectiva novecentista, eminentemente culturalista, de elogio à miscigenação. ${ }^{451}$ É como se de tão aceita e naturalizada a ideia de que o Brasil havia se constituído a partir de um projeto português, apenas coadjuvado por negros e índios, não se conseguisse identificar que no texto de Martius há flagrantes resquícios de concepções derivadas do amplo arcabouço discursivo diminuidor dos não-brancos. Talvez, o próprio campo da História da Historiografia, em ascensão a partir dos anos 1990 no Brasil, em suas menções ao IHGB e ao forjar da História como disciplina no XIX, tenha ficado mesmo aprisionado pela herança da armadilha criada pela própria historiografia oitocentista: a armadilha da História como narrativa nacional, com todas as implicações dos apagamentos que ela impôs. ${ }^{452}$

Mas, o que von Martius fez em Como se deve escrever a História do Brasil foi alertar, em meio a um contexto de negação absoluta da contribuição do negro e

\footnotetext{
karoline Viana. Arena de traços: os escritos de Carl Von Martius e Francisco Freire Alemão na composição de uma historiografia nacional. História Unisinos 18(1):68-77, Janeiro/Abril 2014.

${ }^{451}$ Aqui nos referimos ao arraigado entendimento, reproduzido pelos manuais da educação básica na esteira dos compêndios das interpretações de Brasil -, de que o texto de Martius constituía a gênese discursiva da positivação da miscigenação na definição do brasileiro. Inclusive, produções acadêmicas relativamente recentes, dedicadas a discutir as interfaces entre os autores-intérpretes do Brasil do XIX e do XX passam ao largo de problematizar a hierarquização racial que essas interpretações reproduziam. Aqui nos referimos, em especial, à obra de José Carlos Reis, intitulada Identidades do Brasil e às evidentes naturalizações que realiza da retórica da branquitude civilizada. Ver: REIS, José Carlos. As identidades do Brasil: de Varnhagen a FHC. Rio de Janeiro, Editora FGV, 2003.

452 Acerca dos limites da historiografia de contornos nacionais e também sobre o debate de sua superação metodológica a partir dos anos 1950/1960, ver: GREENE, Jack. Hemispheric history and Atlantic History. In: GREENE, Jack. \& MORGAN, Philip D. Atlantic History: a critical appraisal. Oxford University Press, USA, 2009.
} 
de esvaziamento orquestrado do modo de vida indígena, sobre a indispensabilidade de se considerar a contribuição desses elementos, aos quais ele também se referia como inferiores, na definição do Brasil, tal como ela se deu. Isto é, se considerarmos a longa trajetória de disputas em torno de solucionar a presença tida como indesejável, mas em muitos níveis considerada necessária dos sujeitos não-brancos no Brasil que se pretendia civilizado, as proposições de von Martius constituiriam uma espécie de sinalização a respeito da ineficiência - e do risco - de se criar uma trajetória nacional retrospectiva que impedisse esses contingentes de se perceberem pertencentes. Nos seus termos, a escrita da história do Brasil deveria, portanto, reconhecer, minimamente, que este país era o resultado:

Do encontro, da mescla, das relações mútuas e mudanças dessas três raças (...), cuja história por isso mesmo tem um cunho muito particular. (...) portanto, vendo nós um novo povo nascer e desenvolver-se da reunião e contato de tão diferentes raças humanas, podemos avançar que a sua história se deverá desenvolver segundo uma lei particular das forças diagonais. ${ }^{453}$ (grifos nossos)

A percepção de Martius era a de que a um povo resultante de uma fusão tão inédita de raças deveria corresponder uma narrativa igualmente inédita, um novo modo de se fazer História. Uma História que deixava de ser descritiva para se tornar narrativa, atribuidora de sentido, indicativa de direção. $\mathrm{O}$ argumento em defesa de uma atualização da maneira de se escrever História encerrava qualquer possibilidade de que algum modelo de História já experimentado por outros países ou governos pudesse servir de parâmetro à escrita da História do Brasil. A Comissão do IHGB, instaurada com o objetivo de avaliar as memórias participantes do concurso relativo ao Plano de se escrever a História do Brasil, parece ter aceito bem o argumento de von Martius dedicado a fazer da especificidade do povo a mola mestra da criação de um modelo sui generis de História e também de uma invenção toda peculiar da nação. Tanto que, no parecer final emitido acerca das duas memórias concorrentes, julgavam que o trabalho oferecido por Henrique Julio de Wallenstein, em função de recorrer ao método das Décadas à maneira de Tito Lívio e à organização das matérias tal qual o abade Millot na História da França, não respondia adequadamente à proposta do Instituto, pois acabava defendendo “(...) um método puramente fictício ou artificial, de modo algum apto a produzir uma

${ }^{453}$ Karl Friedrich Phillip von Martius. Como se deve escrever a História do Brasil. RIHGB (6), 1844, p.382. 


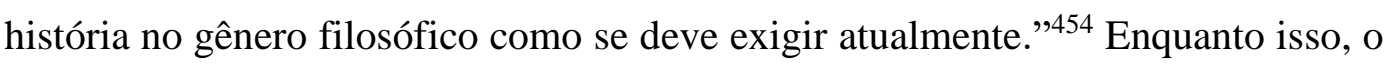
trabalho já publicado de von Martius era reconhecido pelos pareceristas -entre eles Francisco Freire Alemão (botânico e amigo-correspondente de von Martius)- como extenso e profundamente pensado, apesar de considerado inexequível na atualidade. ${ }^{455} \mathrm{~A}$ comissão parecia expressar um misto de admiração e receio pelo texto de K.F.P.von Martius. Admiração pelo que consideravam ser a atualidade metodológica do trabalho, e receio com relação à recepção dessas ideias, sobretudo as que consideravam a participação do negro como elemento constitutivo do caldo nacional, em meio aos círculos letrados, de modo geral, resistentes em aceitar estratégias capazes de reconfigurar, mesmo que minimamente, a condição moral dos pretos africanos ou crioulos, que habitavam - e constituíam - o Império do Brasil.

De qualquer modo, a Comissão não se furtaria a elogiar as soluções apontadas pelo Plano para questões que há muito afligiam aos membros do Instituto, como a relativa ao estabelecimento das épocas da História do Brasil. Ao sugerir que os povos indígenas fossem investigados para além do tempo da conquista, von Martius se demonstrava inclinado a considerar que a primeira época da História do Brasil, conviria mesmo ser firmada como a época dos aborígenes americanos, tal qual defendera, anos antes, Januário da Cunha Barbosa. Tema esse especialmente caro a von Martius, que aos indígenas americanos já havia dedicado alguns outros textos seus, ${ }^{456}$ sempre preocupado em discutir se constituíam populações primitivas, "como não há muito tempo era opinião geralmente adotada" ${ }^{457}$ ou expressões da decadência de uma civilização maior e muito antiga, com uma história perdida, como indicavam as investigações mais aprofundadas. ${ }^{458}$ Esse suposto passado indígena de glória civilizacional precisava, no entender de von Martius, ser desvelado para que então, a partir dele, fosse possível desenvolver sua hipótese principal de que o Brasil resultava da interação entre os autóctones americanos, os portugueses e os africanos. Para tanto, defendia ser importante que

\footnotetext{
${ }^{454}$ RIHGB (9), 1847, p.279.

${ }^{455}$ RIHGB (9), 1847, p.287.

456 GUIMARÃES, Manoel Luiz Salgado. História e natureza em von Martius: esquadrinhando o Brasil para construir a nação. História, Ciências, Saúde — Manguinhos, vol. VII (2), 389-410, jul.-out. 2000.

${ }^{457}$ Karl Friedrich Phillip von Martius. Como se deve escrever a História do Brasil. RIHGB (6), 1844, p. 385.

${ }^{458}$ Ibid., idem.
} 
esforços fossem mobilizados na direção de comprovar que o triste e penível quadro no qual os portugueses encontraram o indígena brasileiro constituía circunstancial desmonte de uma civilização próspera que, capaz de se fazer inteligível na língua tupi, possivelmente havia formado um grande e único Povo similar aos que falavam a língua dos Incas. ${ }^{459}$ Assim, caberia ao Instituto dispensar tantos investimentos quanto fossem possíveis, principalmente no que dissesse respeito às áreas da Arqueologia e da Linguística, para que o enigma dos povos americanos fosse enfim decifrado. Karl F. P. von Martius retomava, assim, mais um dos temas levantados como pauta de programa histórico ainda do primeiro ano de atividades do Instituto: o tema da busca por vestígios que provassem uma civilização anterior a dos portugueses. ${ }^{460}$ Apesar dos cinco anos de intervalo entre as oportunidades em que o tema foi colocado, o intuito da referência parecia continuar sendo o mesmo: o de encontrar provas da existência de uma civilização florescente, capaz de fortalecer a noção de que na origem do Brasil poderia se identificar a existência de um povo coeso e desenvolvido. ${ }^{461}$

Para o IHGB, um outro encaminhamento importante do texto de von Martius foi o relativo ao dilema de adequação das tradições e características regionais à uma História Geral, de silhueta nacional, o que já havia sido motivo de embate, conforme sinalizamos anteriormente, entre os dois principais fundadores do Instituto: Januário da Cunha Barbosa e Raimundo José da Cunha Matos. A sugestão de von Martius se aproximava mais daquilo que defendera, ainda em 1839, o Secretário Perpétuo Januário. Assim, a recomendação do botânico era de que fossem subsumidos os fatos repetitivos relativos à administração das cidades, municípios ou bispados tão comuns nas histórias provinciais, em benefício de uma abordagem que “(...) representa[sse] o estado do país em geral, conforme o que [houvesse] de particular em suas relações com a Mãe Pátria, e as mais partes do mundo." ${ }^{462}$ Aqui, o Plano mais uma vez revela a sintonia entre suas proposições e

\footnotetext{
${ }^{459}$ Karl Friedrich Phillip von Martius. Como se deve escrever a História do Brasil. RIHGB (6), 1844, p.385-6.

${ }^{460}$ Programa Histórico proposto na sessão de 06/04/1839 pelo sócio Desembargador Pontes. Ver: RIHGB (1), 1839.

${ }^{461}$ Karl Friedrich Phillip von Martius. Como se deve escrever a História do Brasil. RIHGB (6), 1844, p.386. A esse respeito vale citar a formulação de Manoel Salgado que considera a ideia de Martius sobre civilização como índice da História. GUIMARÃES, Manoel Luiz Salgado. História e natureza em von Martius: esquadrinhando o Brasil para construir a nação. História, Ciências, Saúde - Manguinhos, vol. VII(2), 389-410, jul.-out. 2000.

${ }^{462}$ Karl Friedrich Phillip von Martius. Como se deve escrever a História do Brasil. RIHGB (6), 1844, p. 400 .
} 
os paradigmas definidores dos novos usos da História. A História que propõe prioriza o sentido geral aos detalhes regionais, reduz o espaço da diversidade em nome da unidade e, por fim, situa a trajetória do país no fluxo histórico universal. Um fluxo capaz de abarcar tanto as manifestações da natureza, como as da humanidade. Um fluxo capaz de dispor linearmente inclusive as próprias leis universais que o regiam, oferecendo, pela via racional, um sentido e uma direção para o mundo. ${ }^{463}$ Partilhando desse horizonte, von Martius alertava, que ao historiador “(...) não compet[ia] tão somente descrever o desenvolvimento de um só povo, circunscrito em estreitos limites, mas sim de uma nação cuja crise e mescla atuais pertencem à História universal." ${ }^{464}$

Como se pode notar, toda a sua formulação estava amarrada pelo argumento central de que para entender o Brasil, e para narrar o Brasil, era preciso reconhecer a mescla das três raças como a contingência definidora do país tal qual ele se apresentava. Essa interpretação sobre quem era o brasileiro e o que era o Brasil conjugava os imperativos coetâneos ligados à formação da nacionalidade a referências racialistas bastante sedimentadas no imaginário branco/europeu, o que se traduzia, por um lado, na enunciação inédita do elemento negro como constitutivo da subjetividade brasileira e, por outro, na manutenção da perspectiva de que a interação racial entre brancos, índios e negros pressupunha a interação entre uma raça predominante e outras duas inferiores. Apesar de se demonstrar convencido da superioridade dos que chamava caucasianos sobre os de cor cobre e os de cor preta, von Martius encontrava espaço para sinalizar algo nunca antes verbalizado: a via de mão dupla dessa interação racial, ou a reação tanto dos indígenas como dos negros sobre a raça predominante. ${ }^{465}$ Isto é, a influência não só dos portugueses predominantes sobre os índios, ou sobre os negros, mas sim a mútua influência de uns sobre os outros, pois, de acordo com o que conhecia de suas andanças pelo Brasil, “(...) nesse país [as três raças] são colocadas uma ao lado da outra (...).[E] esta reciprocidade oferece na história da população brasileira em geral o quadro de uma vida orgânica." $" 466$

\footnotetext{
${ }^{463}$ Reinhart. Estratos do tempo: estudos sobre história. $1^{\text {a }}$ Edição, Rio de janeiro: Contraponto: PUC-Rio, 2014. p.10.

${ }^{464}$ Karl Friedrich Phillip von Martius. Como se deve escrever a História do Brasil. RIHGB, (6), 1844, p.398.

${ }^{465}$ Ibid., p. 382 .

${ }^{466}$ Ibid., p.384.
} 
Embora esse seu entendimento delineasse um novo diagnóstico sobre a constituição étnica do povo brasileiro, então reinventado em sua originalidade, atualizado em seu traço definidor, ele não se furtaria a defender, na esteira da retórica civilizatória encarnada pela branquitude, a necessidade do aperfeiçoamento desse povo brasileiro, desse povo mesclado. A propósito, ele dizia ser indispensável ao historiador reflexivo, isto é, àquele que extrapolasse a mera descrição de fatos e se aventurasse pela seara da história filosófica, estar atento ao poder transformador da ação civilizadora e ao reconhecimento da possibilidade sempre renovada de melhoramento dos modos e dos gostos. Há de se reparar que von Martius não recorre aos mesmos argumentos de aperfeiçoamento racial, outrora mobilizados por José Bonifácio. Se na retórica de Bonifácio havia espaço para que o aperfeiçoamento fosse defendido tanto em termos comportamentais como fenotípicos - através dos casamentos -, em von Martius, a partir da constatação de um povo irreversivelmente mesclado, a responsabilidade das elites brancas - que de alguma maneira pareciam ocupar patamar distinto do ocupado pelo povo mesclado - de aperfeiçoar se destinava estritamente ao aspecto moral. K. F.P von Martius diria, ainda, aos reticentes em acreditar que os não-brancos pudessem ser melhorados, que eles estavam presos a obsoletas concepções, não só civilizacionais, como também historiográficas. ${ }^{467}$

Ciente de que seu argumento central - mesmo recoberto por concepções inferiorizadoras dos não-brancos - possivelmente incomodaria não somente aos que se declaravam abertamente escravistas, como também a alguns dos que, embora se declarassem antiescravistas, conservavam a ideia de que o negro era alheio ao Brasil, von Martius se antecipava, dizendo:

Sei muito bem que Brancos haverá que a uma tal ou qual concorrência dessas raças inferiores taxem de menoscabo a sua prosápia. Mas também estou certo que eles não serão encontrados onde se elevam vozes para uma historiografia filosófica do Brasil. Os espíritos mais esclarecidos e mais profundos, pelo contrário, acharão na investigação da parte que tiveram e ainda tem as raças Índia e Etiópica no desenvolvimento histórico do Povo Brasileiro, um novo estímulo para o historiador humano e profundo. ${ }^{468}$ (os grifos correspondem ao original)

O recado certamente valia para os letrados afinados à retórica escravista propalada por Bernardo Pereira de Vasconcelos, mas, colateralmente, acabava

\footnotetext{
${ }^{467}$ Karl Friedrich Phillip von Martius. Como se deve escrever a História do Brasil. RIHGB, (6), 1844, p.384.

${ }^{468}$ Ibid., p.382-3.
} 
servindo de alerta ao próprio IHGB, especialmente ao Secretário Perpétuo Januário da Cunha Barbosa - falecido no ano seguinte à publicação do texto de von Martius - e aos antigos redatores da Nitheroy então associados ao Instituto. Todos hesitantes em relação à incorporação do negro como elemento constitutivo do Brasil de fato e do Brasil imaginado. Aqui cabe lembrar das justificativas mobilizadas por Januário, ainda no primeiro ano de atividades do IHGB, para persuadir seus pares de sua retórica antiescravista, ventilando a ideia - já pautada por Bonifácio e mais adiante recuperada por Varnhagen - de que a importação de negros seria a responsável por obstaculizar a civilização dos índios e também a dos próprios brancos, um problema, de acordo com eles, passível de ser equacionado com a substituição da mão-de-obra de negros escravizados pelo trabalho livre de indígenas. Ora, assim a demanda por mão-de-obra poderia continuar a ser atendida por uma raça inferior, mas por uma raça autóctone e não mais por uma raça estrangeira, o que acabava por chancelar sob o ponto de vista da ação, o arcabouço subjetivo que vinha sendo difundido pelo Romantismo: o de um Brasil formado por brancos civilizados, por índios submetidos e por negros destituídos de pertencimento, porque vistos como estrangeiros.

Em meio àquele cenário marcado pela concomitante ascensão da economia cafeeira e da retórica do Regresso, o aceite e a publicação do texto de Martius deve ser compreendido como expressão da polifonia dos letrados envolvidos na retaguarda intelectual do Império. Não que no IHGB houvesse dissonâncias expressivas de enfrentamentos políticos significativos, mas coexistiam, ainda que balizadas por uma consciência hierarquizante das variações fenotípicas humanas, distintos entendimentos de como se deveria organizar, no nível do discurso, a formação da nacionalidade. Tanto que o Plano de von Martius, mesmo ousando propor um outro arranjo nacional para além daquele mais aceito, aquele que silenciava a respeito da presença e contribuição negra, dizia-se convencido, assim como parecia ser consensual entre os membros do IHGB, “(...) da necessidade de uma monarquia em um país onde ha[via] um tão grande número de escravos."469 Em outro ponto do texto, quando se propõe a discutir a respeito da influência dos negros importados no desenvolvimento do Brasil, o botânico se exime de julgar positiva ou negativa a escravidão, sugerindo que a análise de seus prós e contras

${ }^{469}$ Karl Friedrich Phillip von Martius. Como se deve escrever a História do Brasil. RIHGB (6), 1844, p.402. 
constituísse um problema a ser resolvido pelo historiador, o que em termos objetivos significava evitar possíveis desgastes na recepção de seu texto pelo IHGB.

De todo modo, ao colocar as reflexões de von Martius sobre a função da História em perspectiva diacrônica é possível identificar, em sua dimensão mais evidente, a defesa de um uso moderno da arte de contar o passado. Uso esse que pressupunha, à medida em que a História passava a significar a história do Estadonação, a diluição das diferenças em nome de uma aparente unidade. Aparente, porque nas suas dinâmicas estruturantes conservava as diferenças, preservava as hierarquias e reiterava os privilégios de uma branquitude - encarnada pelas classes senhoriais, pelos negociantes e pela boa sociedade letrada - que jamais assumiria para si a identidade da mescla. Há um trecho de von Martius elucidativo a esse respeito. Elucidativo de quem eram os mesclados aos quais se referia naquele momento. Nas suas palavras:

O sangue português, em um poderoso rio deverá absorver os pequenos confluentes nas raças índia e etiópica. Em a classe baixa tem lugar esta mescla, e como em todos os países se formam as classes superiores dos elementos das inferiores, e por meio delas se vivificam e fortalecem, assim se prepara atualmente na última classe da população brasileira essa mescla de raças, que daí a séculos influirá poderosamente sobre as classes elevadas. ${ }^{470}$

Nessa ocasião do texto, se pode verificar, ainda, o que o naturalista bávaro vislumbrava acerca do porvir desse Brasil mesclado. Um Brasil no qual a mescla popular influenciaria o que chamava de classes elevadas. Horizonte de país que, por certo, não agradava à branquitude letrada com a qual dialogava. Mas, de qualquer forma, o Brasil que von Martius diz resultar da mescla é o Brasil que Bonifácio dizia ter uma heterogeneidade difícil de superar, um Brasil, nas palavras do naturalista paulista, difícil de amalgamar, porque habitado por brancos, pretos livres, escravos, mulatos e índios e etc. ${ }^{471} \mathrm{~A}$ guinada lançada pelo texto de von Martius é, portanto, a da singularização da ideia de povo brasileiro. Com efeito, sua proposta era de que a História do Brasil contribuísse para que o país deixasse de se pensar como uma pátria de origem indígena, construída e civilizada por descendentes europeus e circunstancialmente habitada por africanos, para que

\footnotetext{
${ }^{470}$ Karl Friedrich Phillip von Martius. Como se deve escrever a História do Brasil. RIHGB (6), 1844, p.383.

${ }^{471}$ Tais observações de José Bonifácio sobre heterogeneidade e amálgama encontram-se na Carta que escreveu a Domingo Antônio de Sousa Coutinho - Conde de Funchal -, em julho de 1813. Ver: Projetos para o Brasil / José Bonifácio de Andrada e Silva: organização Miriam Dolhnikoff. São Paulo: Companhia das letras; Publifolha, 2000, p.88.
} 
passasse a se enxergar como uma nação que, no confluir das contingências, se definia, em termos étnicos, por um povo único que resultava da combinação original de três raças. Mas essa ideia de um povo único, cabe ressaltar, continuava a manter apartados da noção de pertencimento uma parcela significativa dos habitantes negros do país, os escravizados. Isso porque eles continuavam a ser vistos como um contingente alheio ao pertencimento brasileiro, já que eram regidos por uma condição jurídica impeditiva tanto da liberdade, quanto da cidadania. A noção de homogeneidade que von Martius forja ao desenvolver a ideia de um povo brasileiro mesclado não era extensiva a todos os habitantes do território, mas apenas aos que fossem livres, o que permitia, portanto, incorporar na subjetividade nacional um enorme universo de pessoas não-brancas, mas continuava a alijar um outro tanto de pessoas identificadas jurídica e moralmente como escravas, pessoas identificadas racialmente como negras. K.F.P. von Martius disponibilizava, assim, à boa sociedade uma espécie de solução para lidar com dois dos ônus mais incontornáveis da perpetuação do escravismo no Brasil: a miscigenação da população e o crescente número de homens e mulheres de cor livres. O texto de von Martius, ao falar à boa sociedade sobre como se deveria escrever a História do Brasil, falava-lhes, antes, sobre como reinventar as hierarquias que os mantinham em condição de privilégio, mesmo diante de um expressivo número de miscigenados livres. Falava-lhes, ainda, sobre a História como lugar narrativo de uma branquitude civilizada que se via impelida a convencer as suas alteridades de seu projeto de nação. Não por acaso, dizia ele, o poder e a grandeza do Brasil se acharão quando, através de uma História verdadeiramente popular, for possível persuadir seus habitantes de que possuem "a mesma origem, o mesmo fundo histórico e as mesmas esperanças de um futuro lisonjeiro." ${ }^{772}$

${ }^{472}$ Karl Friedrich Phillip von Martius. Como se deve escrever a História do Brasil. RIHGB (6), 1844, p.402-3. 


\title{
5. Considerações finais
}

\section{Ausência do mesmo ou presença alheia}

\begin{abstract}
A noção de raça permitia representar as humanidades não europeias como se tivessem sido tocadas por um ser inferior. (...) Falar delas era, antes de mais nada, assinalar uma ausência - a ausência do mesmo - ou ainda uma presença alheia. ${ }^{473}$
\end{abstract}

Achille Mbembe.

${ }^{473}$ MBEMBE, Achille. Crítica da razão negra. n-1 Edições, 2018, p.42. 
Em um país onde o racismo conseguiu se subterfugiar em uma série de mecanismos de inferiorização nem sempre óbvios à primeira vista, em um país onde as estratégias de branqueamento fenotípico e moral da população buscaram forjar narrativas oficiais sobre um povo unido e miscigenado, em um país onde ainda há espaço para se falar em ausência de racismo, e mesmo de democracia racial, esta tese procura demonstrar como ele está mais presente que nunca, mesmo onde não costuma ser absolutamente evidente. Através do esforço analítico por identificar no pensamento e nas ações dos letrados da boa sociedade argumentos racialistas que, a propósito, em muito antecederam o racismo científico tão presente no pensamento dos intelectuais que interpretaram o Brasil no quartel final do XIX, esperamos poder contribuir para um debate que ainda está longe de ser esgotado: o debate acerca das especificidades que, na origem do Estado brasileiro, delinearam a complexidade do racismo nas ideias e nas atitudes entre as suas populações. Oscilando entre argumentos atravessados por um racismo explícito e alguns outros marcados por racismos mascarados por discursos filtrados pelo devir da homogeneidade nacional, pelos imperativos civilizacionais e pela noção de um povo brasileiro mesclado, a dimensão racialista da construção discursiva do Brasil independente precisa ser reconhecida. E precisa ser reconhecida, ainda, que ela esteve amparada por sobrepostas camadas de saberes, dos filosóficos aos fisiológicos, que chancelaram, por diversas entradas, uma complexa retórica de hierarquização dos povos.

Mas, de início, não tínhamos noção do quão decisivas haviam sido as apropriações dessa tradição hierarquizante das gentes na definição da ideia de Brasil e de brasileiro. Nossa hipótese primeira era a de que haveria, para além da camada mais superficial expressiva dos interesses econômicos e políticos envolvidos na arregimentação do Estado, um componente racialista inerente à retórica civilizatória que sustentava as falas dos letrados dedicados a forjar a unidade, a inventar a nação. Tal hipótese, aventada na ocasião em que reli, com os olhos do século XXI, os textos que Bonifácio apresentou à Constituinte, se comprovaria não apenas nesses textos de 1823, como também em outros textos posteriores, escritos por autores atuantes na redação da legislação do país e nas formulações de uma Literatura e de uma História de contornos nacionais. Não obstante, essa hipótese levaria as problematizações desta tese para um outro lugar. O lugar das múltiplas e versáteis camadas discursivas que foram moldando, na convergência das circunstâncias que promoveram a interação das três pontas do mundo Atlântico, as 
noções de que a paisagem, o clima e os habitantes europeus, identificados como brancos, seriam melhores, porque mais propensos à racionalidade do que os demais povos dos climas quentes com quem estavam em contato.

São esses os povos aos quais se refere Achille Mbembe na epígrafe que abre essas considerações finais. E, ao defini-los como humanidades não europeias, cabe frisar, reivindica um estatuto que nem sempre foi consensual, um estatuto que esteve, durante séculos, em disputa na cultura letrada da branquitude: o estatuto definidor do que caracterizaria o humano, e depois o estatuto demarcador dos supostos graus de humanidade. Disputas em muitos níveis ainda naturalizadas no inconsciente coletivo e que parecem mesmo ser realimentadas pela imagem da pobreza nas ruas, pelo tom de pele dos que realizam trabalhos braçais, pela imagem das campanhas de ajuda humanitária que retratam, à revelia de sua intenção, o tipo civilizado - dotado de conhecimento e que se dispõe a socorrer - e o semblante do despossuído de tudo que ainda constitui a ideia de dignidade humana.

Quando o filosofo camaronês fala da ausência do mesmo, ele fala de uma branquitude que não se reconhece nos que enxerga como diferentes e que, para dar conta de os enquadrar, cria a noção de raça. E a partir de então, quem tem raça são os outros, são as alteridades europeias, sejam elas chinesas, lapônicas, americanas, maoris, malaias ou africanas. Mas é importante destacar, tal como afirmam as irmãs Fields, que a noção de raça, não precede o racismo. ${ }^{474}$ Ela, na verdade, deriva dele, deriva da prática - aliás, não exclusiva dos europeus - de inferiorizar e discriminar a diferença, ainda que tal prática só tenha sido associada ao termo racismo entre os anos finais do século XIX e os iniciais do XX. No mundo ibérico, os únicos encarados como sujeitos de raça foram, não por acaso, os africanos e os índios. Eles constituíam a representação fenotípica e comportamental do que aos europeus parecia alheio. Quando Mbembe se refere a essas humanidades não europeias como uma presença alheia, ele reafirma de outro modo, mas no mesmo sentido, a noção de que a ideia de raça acabou servindo como marcador da diferença. Ele reafirma, nessa esteira, que a ampliação semântica da noção de raça, que no XVIII passa a abarcar as variações humanas, colaboraria para atualizar, pelo viés do racionalismo, as já difundidas concepções compartilhadas no mundo ibérico pelo menos desde o XVI, de que aparências e comportamentos alheios estavam

${ }^{474}$ FIELDS, Barbara J. \& FIELDS, Karen E. Racecraft. The Soul of inequality in American Life. Verso: NY, 2012. 
associados ao que entendiam como barbárie, como selvageria. Por presença alheia há, por fim, de se compreender tudo aquilo que se apresentava ao olhar europeu como indecifrável, aquilo que lhes soava estranho e, portanto, alheio ao que definiam como índices de sua própria interpretação do que seria a humanidade. Assim, os povos indiferentes aos discursos da cristandade, da razão, da civilização e da educação foram considerados como que ocupando um patamar de humanidade anterior ao dos europeus. Patamar europeu que, por uma complexa equação de forças, acabaria se configurando como o único modo de existir, como o único modo de ser humano, já que tudo o que lhe fosse alheio deveria ser convertido, deveria ser aperfeiçoado de modo que a sua presença se tornasse tolerável - e útil - aos que, no mundo atlântico, haviam conseguido impor a sua hegemonia.

Tudo indica, no entanto, que somos testemunhas de um discurso hegemônico que dá sinais de crise, mas que ainda se mantém entranhado, mais do que se pode supor. Um mundo no qual a face nefasta e a face indiscutivelmente positiva do projeto civilizacional disseminado - e também imposto - pela branquitude europeia judaico-cristã parecem estar ameaçadas. Tudo o que parecia consolidado como saber é questionado, as mídias tradicionais como porta-vozes da verdade estão sendo implodidas, as identidades de gênero multiplicadas, as fronteiras nacionais superadas pelas conexões transcontinentais em tempo real. De acordo com Mbembe, a hegemonia europeia está em crise. Mas talvez seja possível dizer, de forma mais ampla, que a hegemonia da branquitude está ameaçada, seja pelo o que a China representa em termos de desenvolvimento tecnológico e controle de mercado, seja pelo que os povos, por séculos subjugados por essa mesma branquitude, têm conseguido pautar. Como talvez seja mesmo característico de momentos transicionais, a resistência à ordem anterior só parece ser possível dentro de uma materialidade ainda definida pelos códigos estruturantes dessa ordem que se questiona. Uma ordem, nesse caso encarnada pela hegemonia discursiva de uma branquitude, que se faz presente nos princípios fundadores do Direito, da História, da Filosofia e das Ciências naturais. Que se fez e se faz presente nos princípios fundadores dos Estados nacionais, competentes em diluir as diferenças, em racializar a unidade. A linguagem também não poderia escapar dessa ampla hegemonia discursiva do branco como universal, tanto que o termo branquitude não é reconhecido pelos programas editores de texto enquanto o termo negritude o é. Tanto que ainda há espaço léxico para que a importância da vida dos negros, ou 
a sua não descartabilidade, constitua uma reivindicação legítima, evidenciando, como todos sabemos, uma apropriação que subverte o sentido original do uso pejorativo do termo negro para o utilizar como denominador de um movimento que pretende romper as engrenagens que sustentam o racismo. Um movimento que parece não conseguir se fazer entender por outros termos que não sejam os mesmos que os racializaram, que os inferiorizaram. É como se estivéssemos ainda presos em uma estrutura que já apresenta os seus primeiros sinais de corrosão, mas que ainda se mantém de pé.

De todo modo, em meio a esse tempo de incertezas, esta tese buscou oferecer pistas para que, talvez, se torne um pouco menos difícil entender o porquê do Brasil ter se tornado o que se tornou, o porquê da miséria e das privações compartilharem traços comuns, não apenas aqui, como no mundo Atlântico em geral. Rostos miseráveis que, não por acaso, coincidem com os rostos dos povos que foram subjugados pelos projetos coloniais e que, nos rearranjos impostos pela criação das nações independentes deles derivadas, acabaram por criar estratégias ou de os eliminar, ou de os dissolver, ou de os manter precariamente vivos. 


\section{Referências bibliográficas}

Fontes primárias impressas

Antonio Gonçalves Teixeira e Sousa. A independência do Brasil. Rio de Janeiro. Tipografia de Paula Brito, vol. I, 1847.

Bernardo Pereira de Vasconcelos. Discurso na Câmara dos Deputados, sessão de 3 de julho de 1827.

Carta aos senhores eleitores da província de Minas

Gerais, assinada em de 30 de dezembro de 1827.

Discurso na Câmara dos Deputados, sessão de 25 de

abril de 1843.

Domingos José Gonçalves de Magalhães. Ensaio sobre a História da Literatura do Brasil. Nitheroy Revista Brasiliense, Tomo I, vol.1, Dauvin et Fontaine Libraires: Paris, 1836.

Suspiros poéticos e saudades. Ministério da Cultura, Fundação Biblioteca Nacional, Fundação Nacional do Livro.

Ferdinand Denis. Scène de la nature sous les tropiques et de leur influence sur la poésie. Paris: Louis Janet, 1824.

Francisco Sales Torres-Homem. Considerações econômicas sobre a escravatura. Nitheroy Revista Brasiliense, Tomo I, vol.1, Dauvin et Fontaine Libraires: Paris, 1836.

Januário da Cunha Barbosa. Programa Se a introdução dos africanos no Brasil serve de embaraço à civilização dos índios, cujo trabalho Ihes foi dispensado pelo dos escravos. Neste caso, qual é o prejuízo da lavoura brasileira entregue exclusivamente aos cativos? RIHGB (1), 1839, pp.123-9.

James Cowles Prichard. Researches into the Physical History of Mankind. $1^{\text {a }}$ ed., 1813.

Jean Jacques Rousseau. Discurso sobre a origem e o fundamento da desigualdade entre os homens. Coleção Pensadores: 1a Edição, São Paulo: Abril S.A. Cultural e Industrial, 1973. 
. Emilio ou da Educação. Coleção Pensadores: 1를 Edção,

São Paulo: Abril S.A. Cultural e Industrial, 1973.

José Bonifácio de Andrada e Silva. Apontamentos para a civilização dos índios bravos do Império do Brasil. DOLHNIKOFF, Miriam (org.). José Bonifácio de Andrada e Silva/ projetos para o Brasil. São Paulo: Companhia das letras; Publifolha, 2000.

. Carta escrita a Domingo Antônio de Sousa Coutinho -

Conde de Funchal -, em julho de 1813. DOLHNIKOFF, Miriam (org.). José Bonifácio de Andrada e Silva/ projetos para o Brasil. São Paulo: Companhia das letras; Publifolha, 2000.

. Carta escrita a Tomás Antonio de Vila Nova Portugal, 1820. SOUSA, Otávio Tarquínio de. José Bonifácio. Coleção Documentos Brasileiros. Livraria José Olympio Editora, Rio de Janeiro, 1972.

Civilização dos índios e coisas do Brasil. DOLHNIKOFF, Miriam (org.). José Bonifácio de Andrada e Silva/ projetos para o Brasil. São Paulo: Companhia das letras; Publifolha, 2000.

. Discurso Histórico recitado na sessão pública de 24 de junho de 1819. Disponível em www.obrabonifacio.com.br. Acesso em 10/05/2018.

. Lembranças e Apontamentos do Governo provisório da província de São Paulo para os seus Deputados. Disponível em www.obrabonifacio.com.br. Acesso em 10/05/2018.

. Os índios são muito imaginativos. DOLHNIKOFF, Miriam (org.). José Bonifácio de Andrada e Silva/ projetos para o Brasil. São Paulo: Companhia das letras; Publifolha, 2000.

. Representação dirigida ao príncipe Regente do Brasil pela Junta Provincial de São Paulo em 24 de dezembro de 1821. Disponível em www.obrabonifacio.com.br. Acesso em 10/05/2018.

\section{Representação à Assembleia Geral Constituinte e}

Legislativa do Império do Brasil sobre a escravatura. DOLHNIKOFF, Miriam (org.). José Bonifácio de Andrada e Silva/ projetos para o Brasil. São Paulo: Companhia das letras; Publifolha, 2000. 
João Gualberto Pereira. Incontestáveis reflexões, que hum Portuguez Europeo oferece aos sentimentais Brasileiros sobre os seus interesses a face do presente.

J. M. Machado de Assis. Obra completa. Rio de Janeiro: Ed. Nova Aguilar, 1962.

K. F.P. von Martius. Como se deve escrever a História do Brasil. RIHGB (6), 1844.

K.F.P. von Martius \& J.B. von Spix. Viagem pelo Brasil. 1ำ vol. Rio de janeiro: Imprensa Nacional, 1938,

Montesquieu. Do Espírito das Leis. Coleção Os Pensadores, São Paulo: Abril S.A, 1를 Edição, 1973.

Raymundo José da Cunha Mattos. Dissertação acerca do sistema de se escrever a história antiga e moderna do império do Brasil. RIHGB (XXVI), 1863.

William Robertson. The History of America. Whitestone, 1777.

Fonte primária manuscrita

José Bonifácio de Andrada e Silva. Ofícios enviados ao Desembargador João Ignácio da Cunha, entre 2/10/1822 e 9/11/1822. Ver: Documentos relativos ao processo mandado instaurar por José Bonifácio contra Januário da Cunha Barbosa, Joaquim Gonçalves Ledo e outros. Fundação Biblioteca Nacional - Obras Raras. Notação: 39,0,22A

\section{Periódicos}

O Sete d'Abril. Edição de 31/10/1835.

O Tamoyo. Entrevista do Velho do Rossio.

Nitheroy Revista Brasiliense, Tomo I, vol.1, Dauvin et Fontaine Libraires: Paris, 1836.

Revérbero Constitucional Fluminense, ํㅡㄱ e X, Rio de Janeiro, 18212. 
Revista do Instituto Histórico e Geográfico Brasileiro (RIHGB). Volumes: I (1839), VI (1844), IX (1847), XXVI (1863).

\section{Obras consultadas}

ANDERSON, Benedict. Comunidades Imaginadas. Reflexões sobre a origem e a difusão do nacionalismo. São Paulo: Companhia das Letras, 2008.

ANDRADE, Debora El-Jaick. Semeando os alicerces da nação: história, nacionalidade e cultura nas páginas da Revista Nitheroy. Revista Brasileira de História, SP, vol.29, №58, p.417-442. 2009.

ANDRADE, Marcos Ferreira de. A revolta de Carrancas: uma das rebeliões mais sangrentas da história da escravidão no Brasil. In: FIGUEIREDO, Luciano. A era da escravidão. Rio de Janeiro: Sabin, 2009.

ARAÚJO, Ricardo Benzaquen de. História e narrativa. In: MATTOS, IImar Rohloff de. (Org.) Ler \& Escrever para contar: documentação, historiografia. Rio de janeiro, Access Editora, 1998. Pp. 221-258.

ARAUJO, Valdei Lopes de. A experiência do tempo: conceitos e narrativas na formação nacional brasileira (1813-1845). São Paulo: Editora HUCITEC, 2008.

ASCENSO, João Gabriel da Silva; CASTRO, Fernando Luiz Vale. (Orgs.) Raça: trajetórias de um conceito. Rio de janeiro, Ponteio: 2014.

BAREL, Ana Beatriz Demarchi. Um Romantismo à oeste: modelo francês, identidade nacional. São Paulo: Annablume, 2002.

BENTO, Maria Aparecida Silva. \& CARONE, Iray. Psicologia social do racismo. Estudos sobre branquitude e branqueamento no Brasil. Petrópolis, RJ: Editora Vozes, 2016.

BETHENCOURT, Francisco. Racismos: das Cruzadas ao século XX. São Paulo: Companhia das Letras, 2018.

BOSI, Alfredo. História concisa da Literatura Brasileira. 37ª edição, São Paulo: Cultrix, 1994.

BOOTH, Wayne. The rethoric of fiction. Chicago: University Chicago Press, 1982. 
BOURDIEU, Pierre. A economia das trocas linguísticas. São Paulo: EDUSP, 1996.

CARDOSO, Wright Eduardo. A cor local e a escrita da história no século XIX: o uso da retórica pictórica na historiografia nacional. Porto Alegre, RS: Editora FI, 2019.

CARRARO, Elaine Cristina. O Brasil como tema no Instituto Histórico de Paris. Revista do Instituto Histórico de Sergipe, ㄲ47, 2017. CARVALHO, José Murilo. CARVALHO, José Murilo de. A Construção da Ordem e Teatro das Sombras. Rio de Janeiro, EDUFRJ/Relume Dumará, 1996.

. Bernardo Pereira de Vasconcelos. Rio de Janeiro, Editora 34, 1999.

; BASTOS, Lucia; BASILE, Marcelo. Guerra literária: panfletos da independência (1820-1823). Vol.1, 2 e 3. Belo Horizonte: Editora UFMG, 2014.

CATELLI, Laura. Pintores criollos, pintura de castas y colonialismo interno: los discursos raciales de las agencias criollas en la Nueva España del periodo virreinal tardio. Cuadernos del CILHA, vol. 13, núm. 2, 2012 Universidad Nacional de Cuyo Mendoza, Argentina.

CERTEAU, Michel de. A escrita da História. Rio de Janeiro, Forense Universitária, 2006.

COSTA, Wilma Peres. Viajantes europeus e o escrever da nação brasileira. In: DOYLE, Don H. \& PAMPLONA, Marco A. Nacionalismo no Novo Mundo. Editora Record: RJ e SP, 2008.

COUTINHO, Afrânio. A tradição afortunada: o espírito de nacionalidade na crítica brasileira. RJ: Livraria Jose Olympio Editora, 1968.

CUNHA, Manoela Carneiro da. Legislação indigenista do século XIX. São Paulo: EDUSP, 1992.

DIAS, Fabiana R. Polifonia e consenso nas páginas da Revista do IHGB: a questão da mão de obra no processo de consolidação da nação. Revista História da Historiografia, Ouro Preto, número 05, Set./2010, p. 175-188. 
Por entre legados e demandas: um estudo sobre os programas históricos do IHGB (1838-1856). Dissertação de Mestrado, PPGH -UERJ, 2009.

DOLHNIKOFF. Miriam. Projetos para o Brasil: José Bonifácio de Andrada e Silva. São Paulo: Companhia das Letras: PubliFolha, 2000.

DOMINGOS, Simone Tiago. Política e Memória: a polêmica sobre os jesuítas na Revista do IHGB e a política imperial (1839-1886). Dissertação de Mestrado, Campinas: IFCH-UNICAMP, 2009.

ELIAS, Norbert. O processo civilizador. Rio de janeiro: Jorge Zahar, 1994. FALCON, Francisco; RODRIGUES, Claudia (Orgs.). A época pombalina no mundo luso-brasileiro. Rio de Janeiro: FGV, 2015.

FAORO, Raymundo. Os donos do poder: formação do patronato político brasileiro. RJ: Editora Globo, 1997.

FERREIRA, Fátima Sá e Melo. Entre viejos e nuevos sentidos: pueblo y pueblos em el mundo ibero-americano entre 1750 y 1850. In: SEBÁSTIAN, Javier Fernandez (Dir.). Dicionario Politico y social del mundo iberoamericano. La era das revoluciones (1750-1850). Madrid, 2009.

FILHO, Domício Proença. A trajetória do negro na literatura brasileira. Estudos Avançados, vol.18, no.50. São Paulo: Jan./Apr. 2004.

FOUCAULT, Michel. As palavras e as coisas: uma arqueologia das ciências humanas. São Paulo, Martins, 2000.

FRANÇA, Jean M. Carvalho. Imagens do negro na literatura brasileira. SP: Brasiliense, 1998.

FREITAS, Ludmila Gomides. Princípios Jurídicos na Colonização do Novo Mundo: O debate sobre a escravidão indígena nas Américas portuguesa e espanhola. Passagens. Revista Internacional de História Política e Cultura Jurídica. Rio de Janeiro: vol. 7, no.3, setembro-dezembro, 2015, p. 456-472.

FREUD, Sigmund. O mal-estar na civilização. Penguin Editora, 2011.

GEGGUS, David. The Haitian Revolution in Atlantic perspective. In: CANNY, Nicholas \& MORGAN, Philip. The Oxford handbook of the Atlantic world. Oxford University Press.

GERBI, Antonello. O Novo Mundo: história de uma polêmica (1750-1900). São Paulo: Companhia das Letras, 1996. 
GODZICH, Wlad. A ilegibilidade de Luiz Costa Lima. In: GUMBRECHT, Hans Ulrich. \& ROCHA, João Cezar de Castro. Máscaras da mímeses: a obra de Luiz Costa Lima. Editora Record: RJ \&SP, 1999.

GOLDMAN, Noemí. Soberania em Iberoamerica. Dimensiones y dilemas de um concepto politico fundamental, 1780-1870. In: SEBÁSTIAN, Javier Fernandez (Dir.). Dicionario Politico y social del mundo iberoamericano. La era das revoluciones (1750-1850). Madrid, 2009.

GREENE, Jack. Hemispheric history and Atlantic History. In: GREENE, Jack. \& MORGAN, Philip D. Atlantic History: a critical appraisal. Oxford University Press, USA, 2009.

GRINBERG, keila. Escravidão, alforria e direito no Brasil oitocentista: reflexões sobre a Lei de 1831 e o "princípio de liberdade" na fronteira sul do Império brasileiro. In: CARVALHO, José Murilo de (Org.). Nação e cidadania no Império: novos horizontes. Rio de Janeiro: Civilização Brasileira, 2007.

O fiador dos brasileiros: cidadania, escravidão e direito civil no tempo de Antonio Pereira Rebouças, Rio de Janeiro: Civilização Brasileira, 2002.

GILROY, Paul. O Atlântico negro: modernidade e dupla consciência. Rio de Janeiro: Editora 34/ UCAM Centro de Estudos Afro-asiáticos, 2002. GUIMARÃES, Carlos Gabriel. Uma leitura sobre o Império do Brasil no contexto do século XIX: diálogo com Ricardo Salles. Almanack.

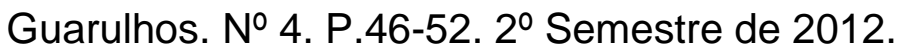

GUIMARÃES, Lucia Maria Paschoal. Debaixo da imediata proteção de Sua Majestade Imperial: o Instituto Histórico e Geográfico Brasileiro (1838-1889). In: R. IHGB, ano.156, n.388, p.459-613, jul./set. 1995. . Justiniano José da Rocha (1812-1862) Ação: Reação:

Transação. Duas palavras acerca da atualidade política do Brasil. pp. 199204. In: PRADO, Maria Emília. Dicionário do pensamento brasileiro: obras políticas do Brasil imperial. Rio de Janeiro: Revan, 2012. GUIMARÃES, Manoel Luiz Salgado. Entre amadorismo e profissionalismo: as tensões da prática histórica no século XIX. Topoi, Rio de Janeiro, dezembro 2002. 
História e natureza em von Martius: esquadrinhando o Brasil para construir a nação. História, Ciências, Saúde - Manguinhos, vol. VII(2), 389-410, jul.-out. 2000.

Nação e civilização nos trópicos:

o Instituto Histórico e Geográfico Brasileiro e o projeto de uma História Nacional. Revista Estudos Históricos, vol.1, nำ1, 1988, p.5-27.

GUMBRECHT, Hans Ulrich. Prose of the world: Denis Diderot and the periphery of the Enlightenment. [S.I: s.n], 2019.

GUTIERREZ, Jorge Luis. A controvérsia de Valladolid (1550): Aristóteles, os índios e a guerra justa. Revista USP, São Paulo, nำ101, p.223-235. MAR/ABR/MAI 2014.

HARDMAN, Francisco Foot; KURY, Lorelai. Nos confins da civilização: algumas histórias brasileiras de Hercule Florence. Hist. cienc. saudeManguinhos, Rio de Janeiro, v. 11, n. 2, p. 385-409, ago. 2004.

HARTOG, François. O espelho de Heródoto: ensaios sobre a representação do outro. Belo Horizonte: UFMG Editora, 1999.

Regimes de historicidade: presentismo e experiências do tempo. Belo Horizonte: Autêntica Editora, 2014.

HEBRARD, Jean. \& SCOTT Rebecca J. Provas de Liberdade: uma odisseia atlântica na era da emancipação. SP: Editora UNICAMP, 2014. HEIZER, Alda. \& ORMINDO, Paulo. (Orgs.) Natureza, ciência e arte na viagem pelo Brasil de Spix e Martius (1817-1820). Rio de Janeiro: Andrea Jackobsson Editora, 2018.

IGGERS, Georg. Historiography in the Twentieth Century. From objectivity to the postmodern challenge. Hanover-London, Wesleyan University Press, 1997.

JANCSÓ, Istvan. Independência, independências. In: JANCSÓ, Istvan (Org.) Independência: História e Historiografia. São Paulo: Hucitec: Fapesp, 2005.

; PIMENTA, João Paulo. Peças de um mosaico ou apontamentos para o estudo da emergência da identidade nacional brasileira. In: MOTA, Carlos Guilherme (Org.). Viagem incompleta: a experiência brasileira (1500-2000). São Paulo: Senac, 2000. 
JASMIN, Marcelo Gantus; FERES JR., João (Orgs.) História dos Conceitos: debates e perspectivas. Rio de Janeiro: Editora PUC-Rio: Edições Loyola: IUPERJ, 2006.

História dos Conceitos: Diálogos transatlânticos. Rio de Janeiro: Editora PUC-Rio: Edições Loyola: IUPERJ, 2007. JUNIOR, R. Magalhães. Três panfletários do Império. Coleção Afrânio Peixoto. RJ: ABL, 2009.

KIENING, Christian. O sujeito selvagem: pequena poética do Novo Mundo. São Paulo: EDUSP, 2014.

KODAMA, Kaori. Os índios no Império do Brasil: a etnografia do IHGB entre as décadas de 1840 e 1860. Rio de Janeiro: Fiocruz; São Paulo: Edusp, 2009.

KOSELLECK, Reinhart. Estratos do tempo: estudos sobre história. 1aㅡ Edição, Rio de janeiro: Contraponto: PUC-Rio, 2014.

. Futuro Passado: contribuição à semântica dos tempos históricos. Rio de Janeiro: Contraponto: PUC-Rio, 2006.

. Uma história dos conceitos: problemas teóricos e práticos. Estudos Históricos, vol.5, ㄲo 10, Rio de janeiro, 1992.

KURY, Lorelai. Ciência e nação: romantismo e história natural na obra de E. J. da Silva Maia. Hist. cienc. saúde-Manguinhos, Rio de Janeiro , v. 5, n. 2, p. 267-291, Oct. 1998.

. No calor da pátria. Revista USP, São Paulo, oำ2, p.8089, dez. - fev. 2006-2007.

Viajantes-naturalistas no Brasil oitocentista: experiência, relato e imagem. Hist. cienc. saúde, Rio de Janeiro, v. 8, supl. p. 863-880, 2001.

LIMA, Ivana Stolze. Cores, marcas e falas. Sentidos de mestiçagem no Império do Brasil. Rio de Janeiro: Arquivo Nacional, 2003.

LIMA, Luiz Costa. História. Ficção. Literatura. São Paulo: Companhia das Letras, 2006.

LINDO, Luiz Antônio. A América dividida entre Cornelius de Pauw e Gabriel Soares de Sousa. Cadernos PROLAM / USP (Ano 11 - vol.2 2012, p.35-44). 
LOPES, José Reinaldo de Lima. lluminismo e jusnaturalismo no ideário dos juristas da primeira metade do século XIX. In: JANCSÓ, István (Org.). Brasil: formação do Estado e da nação. SP: ljuí/FAPESP/HUCITEC, 2003. LORIGA, Sabina. $\mathbf{O}$ pequeno $\mathbf{X}$ : da biografia à história. Belo Horizonte: Autêntica Editora, 2011.

MATTOS, Hebe Maria. Escravidão e cidadania no Brasil monárquico. 2 ed. Rio de Janeiro, Jorge Zahar, 2004.

. Os combates da memória: escravidão e liberdade nos arquivos orais de descendentes de escravos brasileiros. Revista Tempo, ำ6.

MATTOS, Ilmar Rohloff. Construtores e herdeiros: a trama dos interesses na construção da unidade política. Texto apresentado ao Seminário Internacional Independência do Brasil: história e historiografia. São Paulo, USP, 2004.

O Tempo Saquarema. São Paulo, Editora HUCITEC, 1987. . Transmigrar - nove notas a propósito do Império do Brasil. In: PAMPLONA, Marco A. \& STUVEN, Ana Maria (Orgs.). Estado e Nação no Brasil e no Chile ao longo do século XIX. Rio de Janeiro, Garamond, 2010.

MBEMBE, Achille. Crítica da razão negra. n-1 Edições, 2018.

MELLO e SOUZA, Antônio Cândido. Literatura e Sociedade. São Paulo: T. A. Queiroz, 2000. Publifolha, 2000.

MCKIITRICK, Eric L. (Org.). Slavery defended: the views of the Old South. Englewood Cliffs. N.J., 1963.

MELLO, Evaldo Cabral de Melo. A outra independência: o federalismo republicano de 1817 a 1824. São Paulo: Editora 34, 2004.

MYERS, Jorge. Discurso por el contexto: hacia uma arqueologia de la historia intelectual em Argentina. Prismas Revista de História Intelectual, №19. Buenos Aires: Universidad Nacional de Quilmes, 2015.

MOREL, Marco. As transformações dos espaços públicos: imprensa, atores políticos e sociabilidades na Cidade Imperial, 1820-1840. São Paulo: Hucitec, 2005. 
MUNANGA, Kabengele. Rediscutindo a mestiçagem no Brasil. São Paulo: Editora Autêntica, 2019.

NASH, Gary. Sparks from de Altar of '76. International repercussions and reconsiderations of the American Revolutions. In: ARMITAGE, David; SUBRAHMANYAM, Sanjay. The age of revolutions in global context (1760-1840). London: Palgrave Macmillan, 2010.

NEVES, Lucia Maria Bastos Pereira das. A guerra de penas: os impressos políticos e a independência do Brasil. Revista Tempo, UFF, 1999.

. Corcundas e constitucionais: a cultura política da independência (1820-1822). Rio de Janeiro: Ed. REVAN, 2003.

OLIVEIRA, M. da Glória de. Escrever vidas, narrar a história. A biografia como problema historiográfico no Brasil oitocentista. 1a. ed. Rio de Janeiro: FGV Editora/ EDUR/ ANPUH-Rio, 2011.

OLIVEIRA, Maria Edith M. de A. R. de. O país do futuro e o futuro do país: as contribuições de Ferdinand Denis e Von Martius. Anais do $7^{\circ}$. Seminário Brasileiro de História da Historiografia - Teoria da história e história da historiografia: diálogos Brasil-Alemanha. Ouro Preto: EdUFOP, 2013. (ISBN: 978-85-288-0326-6).

PÁDUA, José Augusto. Um sopro de destruição: pensamento político e crítica ambiental no Brasil escravista (1786-1888). Rio de Janeiro: Jorge Zahar, 2002.

PAMPLONA, Marco A. Comentarios sobre las independências y la formacion de estados-naciones em Ibero-America: un abordaje comparado entre la America portuguesa y la America hispânica. In: GONZALEZ BERNALDO, Pilar (ed.): Independencias Iberoamericanas: nuevos problemas e aproximaciones. [S.I: s.n], 2015.

. Nação. In: JUNIOR, João Feres (org.). Léxico da História dos conceitos políticos do Brasil. UFMG.

. Pátria - Brasil. In: SEBÁSTIAN, Javier Fernandez (Dir.).

Dicionario Politico y social del mundo ibero-americano. Tomo 8, Centro de Estudos Politicos y Constitucionales: Madrid, 2014.

Considerações sobre a alteridade nos Diários de Maria Graham durante o período de residência no Chile (1821-1822) e breves comentários sobre suas viagens ao Brasil (1821, 1822 e 1823). 
IN: FALCON, Francisco José Calazans, CARVALHO, Marieta Pinheiro de e SARMIENTO, Érica (Orgs.) Relações de poder no mundo iberoamericano: séculos XVIII-XIX. RJ: Autografia Ed. E Comunicação Ltda., 2019.

PARRON, Tamis Peixoto. A política da escravidão no Império do Brasil (1826-1865). SP: Civilização Brasileira, 2011.

PATTERSON, Orlando. Slavery and social death: a comparative study. Harvard University Press, 1985.

PEREIRA, Luisa Rauter; SENA, Hebert Faria de. A historicidade do político: o debate sobre representação e cidadania no Império Brasileiro (1823- 1840). Revista História da Historiografia. Ouro Preto, n. 22, dezembro/ 2016. p. 258-274.

PAULA, Sérgio Goes de. (Org.). Hipólito José da Costa. São Paulo: Editora 34.

PIMENTA, João Paulo. Portugueses, americanos, brasileiros: identidades políticas na crise do Antigo Regime luso-americano. Revista Almanack Brasiliense, ㄲo 03, maio/2006.

PINAR, William F. O corpo do pai e a raça do filho: Noé, Schreber e a maldição do pacto. Revista Brasileira de Educação v. 13 n. 37 jan./abr. 2008, p. 35-6.

PIÑERO, Théo Lobarinhas. Bernardo Pereira de Vasconcelos e a construção do império. Passagens. Revista Internacional de História Política e Cultura Jurídica Rio de Janeiro: vol. 6, no .3, setembro-dezembro, 2014.

POCOCK, J. G. A. Linguagens do ideário político. São Paulo: Edusp, 2003.

PRATT, Mary Louise. Imperial Eyes. Travel Writing and Transculturation. 2nd ed., London: Routledge, 2008.

RAMA, Angel. A cidade das Letras. SP: Boitempo Editorial, 2015.

RANGEL, Marcelo de Mello. Escravidão e decadência nos Estados Unidos e no Império do Brasil: Torres Homem e seu diálogo com Alexis de Tocqueville. Dimensões, vol. 29, 2012, p. 208-237. 
Poesia, história e economia política nos Suspiros

Poéticos e Saudades e na Revista Niterói: os primeiros Românticos e a civilização do Império do Brasil. Tese de Doutorado. PUC-Rio, 2011.

RAYMUNDO, Letícia de Oliveira. Legislar, amalgamar, civilizar: a mestiçagem em José Bonifácio de Andrada e Silva (1783-1823). São Paulo: EDUSP, 2015.

REIS, José Carlos. As identidades do Brasil: de Varnhagen a FHC. Rio de Janeiro, Editora FGV, 2003.

REIS, João José. Rebelião escrava no Brasil: a história do levante dos malês em 1835. São Paulo: Companhia das Letras, 2003.

RODRIGUES, Luaia da Silva. O Justo Meio: a política regressista de Bernardo Pereira de Vasconcelos (1835-1839). Dissertação de Mestrado, UFF, 2016.

SÁ, Maria Elisa Noronha de. Civilização e barbárie: a construção da ideia de nação. Brasil e Argentina. Rio de janeiro: Garamond, 2012.

SALLES, Ricardo. O Império do Brasil no contexto do século XIX. Escravidão nacional, classe senhorial e intelectuais na formação do Estado. Almanack, Guarulhos, n.04, nov/2012.

SCHUCMAN, Lia Vainer. Entre o "encardido", o "branco" e o "branquíssimo": raça, hierarquia e poder na construção da branquitude paulistana. São Paulo: Veneta Editora, 2020.

SCHWAB, Gabriele. Criando irrealidades: a mímeses como produção da diferença. In: GUMBRECHT, Hans Ulrich; ROCHA, João Cezar de Castro. Máscaras da mímeses: a obra de Luiz Costa Lima. Editora Record: RJ \&SP, 1999.

SILVA, Bruno. As cores do Novo Mundo: degeneração, ideias de raça e racismos nos séculos XVII e XVIII. Lisboa: Lisbon International Press, 2020. SILVA, José Luiz Werneck da. Isto é o que me parece: a Sociedade Auxiliadora da Indústria Nacional (1827-1904). Dissertação de Mestrado, UFF, 1979.

SILVA, Rodrigo Henrique Ferreira da. A linguagem política do bom governo nas leis novas: Francisco de Vitoria e o tomismo espanhol, 14931543. Dissertação de Mestrado. UNESP. Franca, 2016. 
SILVA, Virgínia Rodrigues da. O Revérbero Constitucional Fluminense: imprensa e constitucionalismo na Corte da Independência. Almanack Brasiliense, São Paulo, no 10, p.171-179, nov.2009.

SKINNER, Quentin. Visões da Política. Lisboa: Difel, 2005.

SOUSA, Otávio Tarquínio de. José Bonifácio. Coleção Documentos Brasileiros. Livraria José Olympio Editora: RJ, 1972.

SOUZA, lara Lis Carvalho de. Pátria coroada: o Brasil como corpo político autônomo. São Paulo: Fundação editora da UNESP, 1999.

STARLING, Heloisa Maria Murgel. Como ser republicano no Brasil colônia: uma tradição esquecida. São Paulo: Companhia das Letras, 2018. STAROBINSKI, Jean. As máscaras da civilização: ensaios. São Paulo: Companhia das Letras, 2001. Jean-Jacques Rousseau: a transparência e o obstáculo.

São Paulo: Companhia das Letras, 2011.

SUAREZ, Rosana. Nota sobre o conceito de Bildung (formação cultural). Kriterion, vol.46, no112, Belo Horizonte, Dezembro, 2015.

SÜSSEKIND, Flora. O Brasil não é longe daqui. O narrador, a viagem. São Paulo: Companhia das letras, 1990.

TEIXEIRA, karoline Viana. Arena de traços: os escritos de Carl Von Martius e Francisco Freire Alemão na composição de uma historiografia nacional. História Unisinos 18(1):68-77, Janeiro/Abril 2014.

TODOROV, Tzvetan. Nós e os outros: a reflexão francesa sobre a diversidade humana. Rio de Janeiro: Jorge Zahar Ed., 1993.

VARELA, Alex Gonçalves. Livros, leituras, impressos, bibliotecas e coleções na trajetória do naturalista e homem público José Bonifácio (17801838). In: FERREIRA, Tania Bessone da Cruz; RIBEIRO, Gladys Sabina; GONÇALVES, Monique de Siqueira (Orgs.). 0 oitocentos entre livros, livreiros, impressos, missivas e bibliotecas. São Paulo: Editora Alameda, 2013.

VENTURA, Roberto. Leituras de Raynal e a ilustração na América Latina. Revista de Estudos Avançados. vol.2 no.3 São Paulo Set./Dez. 1988.

WARE, Vron. Branquidade: identidade branca e multiculturalismo. Rio de janeiro: Garamond, 2014. 
WASSERMAN, Fábio. El concepto de nacion y las transformaciones del ordem politicoen Iberoamerica, 1750-1850. In: SEBÁSTIAN, Javier Fernandez (Dir.). Dicionario Politico y social del mundo iberoamericano. La era das revoluciones (1750-1850). Madrid, 2009.

WEINSTEIN, Barbara. Escravidão, cidadania e identidade nacional no Brasil e no Sul dos Estados Unidos. In: DOYLE, Don H. \& PAMPLONA, Marco A.V. Nacionalismo no Novo Mundo. RJ / SP: Editora Record, 2008. 